\title{
THE POETIC POWER OF PLACE \\ COMPARATIVE PERSPECTIVES ON AUSTRONESIAN IDEAS OF LOCALITY
}





\section{THE POETIC POWER OF PLACE \\ COMPARATIVE PERSPECTIVES ON AUSTRONESIAN IDEAS OF LOCALITY}

Edited by James J. Fox

A publication of the Department of Anthropology as part of the Comparative Austronesian Project,

Research School of Pacific Studies

The Australian National University

Canberra ACT Australia

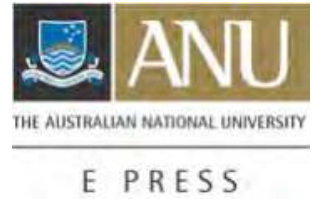




\section{ANU}

E PRESS

Published by ANU E Press

The Australian National University

Canberra ACT 0200, Australia

Email: anuepress@anu.edu.au

Web: http://epress.anu.edu.au

Previously published in Australia by the Department of Anthropology in association with the Comparative Austronesian Project, Research School of Pacific Studies, The Australian National University, Canberra 1997.

National Library of Australia

Cataloguing-in-Publication entry

The poetic power of place: comparative perspectives on

Austronesian ideas of locality.

Bibliography.

Includes Indeex

ISBN 0731528417 (print)

ISBN 1920942866 (online)

1. Place (Philosophy). 2. Sacredspace - Madagascar. 3. Sacred space Indonesia. 4. Sacred space - Papua New Guinea. I. Fox, James J., 1940-. II. Australian National University. Dept. of Anthropology.

III. Comparative Austronesian Project.

291.35

All rights reserved. No part of this publication may be reproduced, stored in a retrieval system or transmitted in any form or by any means, electronic, mechanical, photocopying or otherwise, without the prior permission of the publisher.

Typesetting by Margaret Tyrie/Norma Chin, maps and drawings by Keith Mitchell/Kay Dancey Cover design by Griffiths and Young Design/Bronwyn Dillon Printed at National Capital Printing, Canberra

(C) The several authors, each in respect of the paper presented, 1997 This edition (C) 2006 ANU E Press 


\section{Table of Contents}

Acknowledgements $\quad$ ix

Chapter 1. Place and Landscape in Comparative Austronesian Perspective James J. Fox

Introduction

Current Interest in Place and Landscape

Distinguishing and Valorizing Austronesian Spaces

Situating Place in a Narrated Landscape

Topogeny: Social Knowledge in an Ordering of Places 8

$\begin{array}{ll}\text { Varieties, Forms and Functions of Topogeny } & 12\end{array}$

$\begin{array}{ll}\text { Ambiguities and Indeterminacy of Place } & 15\end{array}$

$\begin{array}{ll}\text { References } & 17\end{array}$

Chapter 2. The Water That Blesses, The River That Flows: Place And The Ritual Imagination Among The Temanambondro Of Southeast Madagascar Philip Thomas

The Place-Ness of Water $\quad 23$

Temanambondro: A Riverain People 26

Life, Death and the River $\quad 29$

The River and the Polity 32

The "Roots" of Place $\quad 35$

$\begin{array}{ll}\text { References } & 37\end{array}$

Chapter 3. Remembering Origins: Ancestors And Places In The Gumai Society Of South Sumatra Minako Sakai 43

Introduction 43

The Ethnographic Setting 44

The Generation of Origin Points 46

Genealogical Idioms by Which Relationships to Places are Expressed $\quad 50$

Origin Rituals, Ritual Specialists and Ritual Places 51

Conclusion $\quad 56$

References $\quad 56$

Chapter 4. The Contested Landscapes of Myth and History in Tana Toraja Roxana Waterson $\quad 63$

Houses, Myths and Genealogies in the Toraja Landscape 64 
Houses and Their Myths: Connections With Lowland Kingdoms 67

Sky Men and Water Women: The to Manurun Ancestors 70

The "Ancestors of the Same Dream": Memories of Bugis

Incursions $\quad 73$

Conclusion: Ancestors, Precedence and the Division of Meat $\quad 78$

References $\quad 83$

Chapter 5. Genealogy and Topogeny: Towards an ethnography of Rotinese ritual place names James J. Fox 89

$\begin{array}{lr}\text { Introduction } & 89\end{array}$

The Rotinese Context 90

Names and the Cosmology of Place $\quad 90$

The Names of Roti and the Symbolic Co-ordinates of Place 91

The Ritual Names of the Domain of Termanu 92

Narrative Topogeny: The Chant of the Origin of Rice and Millet 93

Mapping the Path of Rice and Millet onto the Body of the Island 97

The Creation of Ritual Space $\quad 99$

$\begin{array}{ll}\text { References } & 100\end{array}$

Chapter 6. Mapping With Metaphor: Cultural topographies in West Timor Andrew McWilliam 101

Introduction 101

$\begin{array}{ll}\text { Named Place } & 101\end{array}$

$\begin{array}{ll}\text { Agnatic Paths } & 103\end{array}$

$\begin{array}{ll}\text { Affinal Paths } & 109\end{array}$

$\begin{array}{ll}\text { References } & 112\end{array}$

Chapter 7. Knowing Your Place: Representing relations of precedence and origin on the Buru landscape Barbara Dix Grimes 115

$\begin{array}{ll}\text { Origin Places } & 116\end{array}$

$\begin{array}{ll}\text { Taboo Places } & 124\end{array}$

$\begin{array}{ll}\text { Conclusion } & 128\end{array}$

$\begin{array}{ll}\text { References } & 128\end{array}$

Chapter 8. Speaking of Places: Spatial poesis and localized identity in Buli Nils Bubandt $\quad 131$

Introduction 131

The Spatial Conditions of Subjectivity in Buli 133

Basic Orientation in Buli 135

$\begin{array}{ll}\text { Relative Distance and Movement in Deixis } & 137\end{array}$ 
Placing Things and Using Space

Space, Subject, Body

Seeing the World From Buli

The Political History of Moral Space

Tradition, Modernity and Spatial Involutions

Conclusion

References

Chapter 9. From the Poetics of Place to the Politics of Space: Redefining Cultural Landscapes on Damer, Maluku Tenggara Sandra Pannell

Introduction

The Poetics of Place: Constructing Maps

The Politics of Space

Conclusion

References

Chapter 10. Seating the Place: Tropes of body, movement and space for the people of Lelet Plateau, New Ireland (Papua New Guinea)

Richard Eves

Beyond Cartesian Dichotomies: Conceptualizing Space and Body

Larada: Delineating and Demarcating Space

Larada Spirits: The Attachment of People to Their Place

Seating the Place

The Mobile Body and Place

Conclusion

References 



\section{Acknowledgements}

This volume, like others in this series, has taken a long time to make its appearance. Several of the papers - those by Eves, Fox, McWilliam and Pannell - were originally presented on 30 September 1992 at a panel of the Annual Conference of the Australian Anthropological Society held at The Australian National University. It is around these core papers that the rest of the volume has slowly taken shape.

Dr Katy Bellingham, Margaret Tyrie, Norma Chin and Dr Barbara Holloway have all carried out careful editorial work on this volume at different stages in its production. Special thanks are due for all of their labours in producing this volume, especially since the task has had to be passed through a succession of editors.

The photograph on the cover, set against the background of a Toraja textile, shows an old Toraja man and his dog standing beside a deata offering-pole erected as part of a medatu ritual held when rice is ripening in a field. The rice field for which the pole was erected is called Rattang Sura' and belongs to the old tongkonan of Tumakke. The photograph was taken by Roxana Waterson.

The design of the cover was created by Bronwyn Dillon of Griffiths and Young; maps and figures were produced by Keith Mitchell and Kay Dancey of the Cartography Unit, RSPAS; and the index was compiled by Norma Chin and Barbara Holloway. 



\title{
Chapter 1. Place and Landscape in Comparative Austronesian Perspective
}

\author{
James J. Fox
}

\section{Introduction}

The papers that comprise this volume examine ways in which social knowledge is framed and vested in particular landscapes. Each paper describes a specific Austronesian locality and considers both the cultural creation of this setting and the ways in which knowledge is maintained, transformed and remembered in relation to it.

Each account is focused on a separate Austronesian-speaking population. These populations are located over a wide area stretching from Madagascar to Melanesia with languages representative of currently recognized major subgroups of the Austronesian language family: West Malayo-Polynesian, Central Malayo-Polynesian and Eastern Malayo-Polynesian, including speakers of both the Southwest Halmahera-West New Guinea and the Oceanic subgroups. The strategic purpose of this collection is to carry forward the comparative enterprise begun under the auspices of the Comparative Austronesian Project of the Research School of Pacific and Asian Studies. As such, this volume forms part of a series that has explored various comparative topics and each has featured a different array of Austronesian-speaking groups.

The intention is to give impetus to a comparative perspective that takes into account the whole of the Austronesian-speaking world. Identifying what may be common to all of the Austronesian peoples and what are critical cultural innovations in different regions is an essential part of this effort. The differentiation of Austronesian languages among and within regions is as fundamental as is a general perspective on the language family as a whole.

Among linguists, a great deal of work on the subgrouping of Austronesian languages remains to be done, especially within the large provisionally-constructed subgroup known as Central Malayo-Polynesian which covers a considerable area of eastern Indonesia and provides linkages from west to east. In many cases, in eastern Indonesia, given the time depth for the Austronesian penetration of the area and the possibilities of movement among numerous islands, speakers of languages who are now contiguous may represent different migratory movements. Recognition of these historical differences among Austronesian populations is as important as is the recognition of broadly shared commonalities. 
Equally important to this comparative effort, especially for anthropologists, is the task of creating a mode of analysis that will establish the basis of a comparative discourse appropriate to examination of the whole range of Austronesian societies. Such a discourse is needed to provide theoretical linkages between specific regional concerns (with societies such as those of Madagascar, or Borneo, or Oceania, or Micronesia) and the more general comparative concerns of anthropology that focus on the nature of society and of the human endeavour.

All of these efforts are in an early exploratory phase. They offer at best a set of goals - distant goals in a voyage of Austronesian exploration. Each of the volumes of the Comparative Austronesian Project has endeavoured to carry forward these efforts.

A feature of this volume is its examination of a range of new comparative issues in relation to place and landscape but, at the same time, it addresses various concerns considered in previous volumes of the Comparative Austronesian Project. Thus, for example, the organization and domestication of space, considered in Inside Austronesian houses, as well as ideas of origin and precedence, considered in Origins, ancestry and alliance, continue to be recognized as fundamental, related topics to be examined in relation to place.

\section{Current Interest in Place and Landscape}

The past several years has seen the publication of a number of collections of essays devoted to the consideration of place, space and landscape. These publications include the theme issue of Cultural Anthropology edited by Arjun Appadurai on "Place and Voice in Anthropological Theory" (1988), Barbara Bender's Landscape: politics and perspectives (1993), Eric Hirsch and Michael O'Hanlon's The anthropology of landscape: perspectives on place and space (1995), and Steven Feld and Keith H. Basso's Senses of place (1996). At an initial appearance, it might seem that the cumulative effect of these publications is to create a new focus within anthropology. However, what is most remarkable about reading the various papers in these collections - many of which are individually brilliant — is the diversity of perspectives, perceptions and philosophical orientations that are presented under a seemingly similar rubric. The rubric itself remains elusive. "Landscape" is thus variously represented as a topographic vista, as an intimate emplacement of local experiences, or as the "interanimation" of sense, speech and memory. Landscape, soundscape and ethnoscape vie with each other in the presentation of an ethnography of place. If there is to be an ethnography of place, it is a focus for study still in early efflorescence.

Moreover, if one considers the various papers in each of these different volumes, they portray a remarkable diversity of localities from Cibecue in east-central Arizona or Sawaieke on Gau in Fiji to the Roper Bar Police Reserve 
in the Northern Territory of Australia, or from Stonehenge to New Ireland, from Belfast or Vastergotland to North Carolina or eastern Madagascar. Each of these collections presents multiple visions of place, even as each volume's separate papers particularize a specific locality. Their impact is to stress the multiplicity of ways in which places are socially constructed and personally experienced.

By contrast to the contributions of those collections, there is one area Aboriginal Australia - where a concerted and well-focused consideration of country, place and landscape has had a significant impact and has transformed our ethnographic understanding. Recent research on place in the ethnography of Aboriginal Australia has in fact produced a coherent discourse that offers significant comparative perspectives.

Extending important insights first articulated by Stanner (1964), Strehlow (1970) and Munn (1970), a number of recent ethnographies have made landscape a central concern to the explication of local social knowledge. They include Fred Myers' Pintupi country, Pintupi self: sentiment, place and politics among Western Desert Aborigines (1986), Ian Keen's Knowledge and secrecy in an Aboriginal religion (1994), Howard Morphy's Ancestral connections: art and an Aboriginal system of knowledge (1991), and Nancy Williams' The Yolngu and their land: a system of land tenure and the fight for its recognition (1986).

The important feature of this research is the way in which landscape is shown to provide the underpinnings of a diverse array of social knowledge. Although the Austronesian ethnographic field differs markedly from that of Australia, this research in its coherence, comprehensiveness and potential comparative significance offers an example of how similar research might be pursued among Austronesian-speaking populations. It provides an important comparative reference.

The papers in the present volume portray particular places in the Austronesian-speaking world - for the most part, localities of little recognized significance. For several contributors, their papers represent their first publication and the first time that the locality they describe is given ethnographic representation. Although made up of individual papers, this volume, as a whole, is not intended to provide a scattering of separate visions of place. Rather, it endeavours to focus, in a tentative and exploratory way, on a few related ethnographic portraits, relying on a partially shared comparative framework directed to a common field of study. As such, this collection has been assembled with a view to considering whether there are common patterns to the ways in which place is represented among Austronesian-speaking populations. 


\section{Distinguishing and Valorizing Austronesian Spaces}

Implicit in this volume are a number of understandings and distinctions that derive from the field of Austronesian research and thus create a general background to a specific examination of place.

Of critical importance is the distinction, which figures prominently in several papers, between the ordering of space by directional co-ordinates and the specific identification of places within a locality. The ordering of space is fundamental to the creation of locative identities and to some extent reflects patterns of deixis that are a key feature of Austronesian languages. Although it is possible to distinguish various linguistic and social means by which such ordering is achieved, it is the historical embedding of this local creative process that is the prime concern.

Nils Bubandt, in his paper on the orientation system of the Buli of Halmahera, describes in detail the linguistic bases for this spatial orientation and he aptly designates the processes of deixis as a form of "spatial poesis". His paper examines how linguistic differentiation is relied upon to create a "moral space" in which cultural identities and local subjectivities find their appropriate place. He notes:

The "upward" domain is thus both socially and morally distinct from the rest of social space: it is the foreign, distant, the invitingly prosperous yet treacherous unknown.

A double process is involved in this spatial poesis. There is first a differentiation of space according to various co-ordinates and then there is the valorization of a particular co-ordinate or axis. Philip Thomas, in his paper on the Temanambondro of southeast Madagascar, notes a similar process of valorization of differentiated space. He writes that

the spatial articulation of hierarchy is principally played out through the cardinal points: north and east are respectively "above" (ambony) and therefore superior to south and west, themselves "below" (ambany).

Similarly my paper refers to the linguistic axes of spatial differentiation on the island of Roti as "symbolic co-ordinates". In the Rotinese case, such co-ordinates are linked to a conception of the island as a creature resting in the sea:

The island of Roti is conceived of as having a "head" (langa) and a "tail" (iko); a "right" side (kona) and a "left" side (ki). The "head" of the island is in the east (dulu), its "tail" in the west (muli). The "right" side of the island is to the south, the "left" side to the north.

In this system, south and east are considered superior to north and west. Applying another set of directionals, one moves "upward" to the "head" of the 
island and "downward" to its "tail". Many names of specific places on Roti, especially in ritual reference, are based on these symbolic co-ordinates and assume a knowledge of their significance.

As Bubandt argues in his paper, such co-ordinates are more than an abstract reference system; they form the basis for social praxis. In some cases, as on Roti or in Madagascar, they provide for the orientation of houses and tombs and for the performance of rituals, the categorization of settlements and the evaluation of the directions of origin. (See Sudo 1996 for a particularly striking example of this for Micronesia.)

The indigenous peoples of Buru, discussed by Barbara Grimes, conceive of their island as a body. For them, the crucial directional axis is "upstream" (dae)/"downstream" (lawe). At the centre of the island is a lake (Rana). Grimes writes that since

the lake is as far "upstream" as one can go on the island, Rana is also a metonym for the interior of the island, symbolizing the cultural value of upstream over downstream, of the mountains over the coast.

This co-ordinate, with Rana at its centre, provides the basis for a more complex moral ordering:

An ordering of precedence thus flows from elder to younger, from upstream to downstream, from the headwaters in the mountains at the centre of the island to the periphery of the island at the coast.

In the general ethnographic literature, a great deal of attention has been given to Balinese directionals and their cosmological and personal significance. Like the system on Buru, the term kaja for the Balinese defines a propitious direction toward the interior of the island not, as on Buru, toward a lake, but to a mountain, generally that of Gunung Agung. By contrast, the term kelod refers to the less propitious direction toward the sea.

In a comparative examination of the western Austronesian directional systems, K. Alexander Adelaar (1997) identifies * Daya, "toward the interior" and * laSud, "toward the sea" as proto-Austronesian terms that define a "fundamental axis of orientation in Austronesian societies". The Balinese retain this orientation and the terms that define it are reflexes of the proto-Austronesian terms formed by the addition of $k(e)-$, "towards". The Buli, described by Bubandt, also make a similar distinction between "landside" and "seaside" but only the term for seaside, polau, reflexes * laSud. It is indicative that various Austronesian orientation systems preserve reflexes of proto-Austronesian terms but it is of more interest to consider the formal similarities among these various systems.

The directional systems that Adelaar describes for western Indonesia and Madagascar all appear to be "two-axis" systems. The alignment and designation 
of the two axes vary. Most such systems appear to have been relative orientation systems and may remain so, as for example on Bali. Whereas some systems have two relative axes, many align one axis with the rising and setting sun and allow only the second axis a relative alignment (to the mountain/sea, landward/seaward or upstream/downstream). Several of these systems, as for example on Java, have become fixed to represent the cardinal directions but even where these cardinal direction systems hold sway, local relative systems still persist. Hefner reports that some Tengger of East Java still retain a relative directional system that designates Mount Bromo, the mountain around which they are settled, by what is now the standard Javanese term for "south" (1985:68).

Most two-axis systems, as Adelaar has shown, can be "doubled" to create four-axis systems. This "doubling" appears to be a historical creation, possibly the result of Malay influence, since all four-axis systems share the same features and many similar lexical designations.

Equivalent comparative research on directional systems in eastern Indonesia has yet to be done. Many such systems, as for example those of the Rotinese and Timorese, are recognizable two-axis systems. Others appear to involve three axes. The Buli system described by Bubandt offers a good example of such a system but other such systems are also well documented (Forth 1991). The critical need is to examine how different directional axes, whatever their number, are combined with other topographic demonstratives and with particular verbs of motion to create the systems that local populations use in daily life (see Barnes 1988; Donohue 1995). The issue is therefore not one of predetermined stasis but of moving orientation within a specific landscape.

\section{Situating Place in a Narrated Landscape}

Although places may be located in relation to an oriented space, they are not the creation of the directional system by which they can be located. Specific places identified by name form a critical component of a social knowledge that links the past to the present. All the papers in this volume stress this point by noting, in different ways, the importance of narratives of the past in defining a landscape of specific places.

Andrew McWilliam, for example, describes an orientation system for the Atoni Pah Meto of Timor that is an analogue of that of the neighbouring Rotinese. With "head" to the east, which is referred to by a term for the rising sun, with "foot" to the west and the setting sun, and with north as "left" and "right" as south, this system implies a "prostrate human form with arms outstretched and the head oriented to the east". However, as he insists, this system is only "one type of cognitive map" by which people orient themselves. Relations to named places draw on a complex social discourse. The array of these places "projects the record of ancestral experience into the contemporary world". His paper goes 
on to examine the complex narrative traditions that are actively maintained by Meto groups.

Thus a landscape of places forms a complex structure of social memory. Quoting Fentress and Wickham in their study, Social Memory (1992), Roxana Waterson notes "the constantly recurring importance of local geography as a structure for remembrance". She makes evident that there is no simple structure of remembrance in Tana Toraja but rather different "contested landscapes of myth and history". Sandra Pannell, writing of the island of Damer in Maluku, emphasizes the same point: "The landscape, as narrated and geographic text, thus signposts forms of social behaviour, rights, responsibilities and relations." This "creation of place" she describes as a form of poesis by which "Mayawo narratives effect and recall ... simultaneously a construction of social identity and social relatedness." As she goes on to make clear, this poesis involves a two-way process because the "landscape also serves as the empirical foundation for the veracity of Mayawo stories in the same way that the narratives establish the authenticity of the cultural geography..." So, too, in the case of the Lelet of New Ireland, discussed by Richard Eves,

the narratives of the movements of larada [the territorial spirits of the Lelet] are the means through which the landscape is imaginatively fashioned, giving people identification and attachment to place.

Such narratives define significance and assign it to a landscape. Among Austronesians, water is regarded as fundamental to, and in many instances coterminus with, any specification of a landscape. As Thomas makes clear for the Temanambondro, the Manambondro River is "a constant feature of the environing landscape and a focal image in people's sense of place". The river both creates a common "origin" and differentiates among "ancestries" who are identified by separate tombs spatially arranged at its mouth. In a similar vein, Grimes reports for Buru that each ancestral founder is associated with a different river or stream, and house-circles derived from these founders establish themselves in an order of precedence that has a clear spatial embodiment.

McWilliam notes that among "a bewildering array of named places" on Timor, names marked by terms for water are notable because of the "importance of water sources for settlement sites". In their narrative recitations, Meto groups link the term "water" with that for "rock", invariably tracing their origin to some specific, usually striking, limestone outcrop. The same pattern is recognizable in Toraja. Waterson writes:

Features of a landscape such as mountains and rivers have a place in myth and oral histories, especially the genealogies and accounts attached to noble origin-houses. Some of these myths tell of founding ancestral 
couples ... of whom the man is said to have descended from the sky on to a mountain top, and married a woman who rose out of a river pool.

Not entirely unlike the traditions of the Toraja, the founding ancestor of the Gumai of South Sumatra, described by Minako Sakai, is believed to have descended to Earth on Mount Seguntang and married a princess from Bengkulu. Eventually his line produced nine sons. Each of these nine sons "followed one of the Nine Great Rivers that flow across South Sumatra to establish a new village".

As the papers in the volume indicate, the various narratives that define the landscape among Austronesian populations and give significance to specific places within it, share common patterns and thus produce a variety of notable resemblances. A prominent feature in many of these narratives is the recounting of a process of domesticating the landscape in which houses and settlements of origin figure prominently as do the memories of previous sites of residence (see Toren 1995 for an exemplary examination of the idea of ancestral sites in Fiji).

Equally prominent, as part of the same process, are narratives that define paths through the landscape, setting forth ancestral journeys or recounting the passage of objects from place to place.

\section{Topogeny: Social Knowledge in an Ordering of Places}

This volume introduces the notion of topogeny, the recitation of an ordered sequence of place names. Like genealogies, topogenies figure prominently among Austronesian populations but have not been recognized as a distinct means for the ordering and transmission of social knowledge. In so far as a sequence of names can be attached to specific locations in an inhabited landscape, a topogeny represents a projected externalization of memories that can be lived in as well as thought about.

Topogenies take a great variety of forms among Austronesian populations. They may recount the journey of an ancestor, the migration of a group, or the transmission of an object. In introducing the notion of topogeny, I have selected one from among a variety of topogenies recounted by Rotinese. It traces the transmission of rice and millet from the sea throughout the island and back to the sea again. Other forms of topogeny exist. Thus, for the population of Termanu, there is an important topogeny that describes the origin and wandering of two great rocks that eventually come to settle along the north coast of the island and become a defining feature of the landscape of the domain of Termanu.

McWilliam provides an excellent example of the most common form of topogeny among the Atoni Meto. This topogeny traces the migration (and expansion) of a "name group" or clan (kanaf) from its point of origin through the mountains and valleys of Timor. In its semantically condensed form, this 
kind of topogeny relates the entire history of a large group and its encounters with other groups as the wandering of a single person represented in narrative first person (see Rumsey 1996 for other examples of this kind of first person narrative). As in Rotinese topogenies, persons, places and objects merge as a recitation of names.

Pannell describes similar itineraries among the Mayawo as "a landscape criss-crossed by a multitude of significant pathways and punctuated by a number of noumenally important places". Instead of regarding these narratives as histories, she prefers the term "topostories". Waterson presents yet another form of topogeny, one that is inserted within a Toraja narrative which begins with creation and then goes on to recount the marriages of the male and female ancestors who populated Tana Toraja. After providing a genealogy of their descendants who spread out and founded houses throughout the land, the narrative embarks upon a litany of the names of the ancestors who resisted Bugis incursion. This litany identifies these ancestors not by their individual genealogies but in relation to specific places, thus moving in an ordered fashion through the Toraja landscape.

Examples of other topogenies, either in simplified or elaborate form, are recognizable throughout the Austronesian-speaking world. A particularly striking example is evident in narratives of Belau as described by Richard Parmentier in The Sacred Remains. His description of Belau's mythology links the two common Austronesian metaphors, that of the "path" with its "origin" to the botanic image of the growing and spreading "tree" that extends from its base. Parmentier writes:

The account of the origin of Belau (uchul a Belau) in both geographical and cultural senses is phrased in terms of the construction of a path (rael) along which motion takes place from a beginning point (uchul) at Lukes or Mekaeb to an ending point (rsel) at Oikull. The key word which appears in the phrases "origin of Belau" and "beginning of a path" is uchul, which means not only "origin" and "beginning point" but also more generally "source," "basis," "cause" and "reason." The basis for these extended meanings appears to be the meaning "tree trunk," so uchul is simultaneously the physical support for upper limbs and point at which growth originates (1987:132).

Equally remarkable are the cycles of origin accounts, provided by Joël Bonnemaison, of the itineraries of the first "white rocks" that circled the island of Tanna in Vanuatu, forming and shaping the land (tan). Many of these rocks came ashore and moved through the land along traditional paths in the mountains and valleys of the island, giving rise eventually to a complex geography of presently immobile stones, each with special characteristics. The knowledge of the many different pathways of these stones, the names of places along the 
pathways, the concentration and dispersion of the stones and the intimate knowledge of their powers constitute critical social knowledge for the population of Tanna $(1985,1987)$.

The creation of this world predated the emergence of the first men from stone. With the appearance of the first humans began the vegetative transformation of this initial stony world. Men are thus compared to trees that must be rooted in the earth. In the words of a Tanna man, as quoted by Bonnemaison: "Men were rooted to the soil but women were like birds who fly above the trees, only descending where they see good fruit" (1985:37). Bonnemaison describes this local pattern of path and place as a "paradigm of origins constituting an archetypal space at the beginning of the world" (1987:413). Most interesting, as well, is that this same paradigm involves a kind of prehuman domestication of space since the "houses" of the first rock beings are explicitly referred to as canoes (niko) that traverse both land and sea.

Less spectacular but no less significant are the topogenies of the Ilongot as noted by Renato Rosaldo in his accounts of local history. He writes:

Ilongots, in fact, care intensely about the relative sequence of a succession of events, but these excursions into the past are meticulously mapped onto the landscape, not onto a calendar (R. Rosaldo 1980:48).

As Michelle Rosaldo observed, each Ilongot settlement consists of

a core group of closely related families who are apt to share a common history of residence, having lived in close proximity over years of intermittent movement ... It is this history of co-ordinated moves ... that lends a settlement its viability as an ill-defined yet generally recognized and cooperating social group (1980:5).

The biographies of individuals follow the same topogenic pattern as do the migration histories of different groups:

People readily listed in succession the names of the places where they had "erected their houseposts" and "cleared the forest". This task was as culturally appropriate for them as listing the place names along any walk they took ... (1980:42).

More formal and more elaborate topogenies are characteristic of the populations of West Seram who recount extensive topogenies of the migration of ancestral groups throughout the island. These topogenies are represented as the growth of an immense banyan tree at the centre of the island that extends its branches laterally, putting down new roots from above and thus creating a tangle of trunks and branches (Boulan-Smit 1997). 
For the people of Koa on Palu'é, a small island off the north coast of Flores, Michael Vischer has recorded even more extended topogenies. At the end of every five to ten year ceremonial cycle, the Koa people recite a chant that recounts the voyage of the first ancestors who travelled from the "rim of the earth in the west" bringing with them "the black patola stone" that provides the primordial substance of the island. Like recitations on Timor or Roti, this chant is structured by formal parallelism and "consists of a series of some two hundred paired place names". Knowledge of the first of these names is restricted to ceremonial officiants, whereas the knowledge of the names of places within Koa is less restricted. In his analysis of this chant, Vischer carefully sets forth the path of these place names in terms of a three-axis set of directionals that indicate movement through the landscape of Koa (1992:92-106).

Examples of topogenies also abound among the populations of western Indonesia. Some of the most elaborate of these topogenies are to be found recorded in the written narrative traditions of Java and Bali. The earliest and best known of these recorded works is the Old Javanese kakawin, the Nägara Kĕrtāgama ("Ordered is the Realm") written in 1365 by the poet Prapañca. A large segment of this great text is constructed as the journey of the ruler, Hayam Wuruk, through his kingdom. Before this royal progress begins, the text recounts the names of some 107 distinct states and domains that like "stars and planets", form concentric "ring-kingdoms" around the royal realm. The journey of the Hayam Wuruk through his realm begins at the centre of Majapahit and moves eastward through an initial fourteen places to an assembly point at Kapulungan and then steadily onward through a succession of a hundred named places to a site on the Sampean River, Patukangan, where the itinerary of the ruler turns back, proceeding through a further forty-seven named places to enter once more the inner realm.

In total, the narrative recounts a succession of 162 places that together, by their great number, delineate the length and breadth of the kingdom and exalt the power of the ruler (see Pigeaud 1960 III:16-42, IV:29-115). Although a majority of the places named in this literary topogeny can no longer be identified, a sufficient number are recognizable. These names provide a clear indication that the journey followed an ordered sequence. The naming of these places seems to have constituted a litany of power and control.

Similarly, when power was lost, the Javanese and Balinese narrative traditionwould invoke an ordered litany of places in revolt. Thus in the Babad Dalem, when Sri Kresna Kapakisan, the ruler sent by the kingdom of Majapahit toestablish authority on Bali, is faced with insurrection, the Babad identifies theextent of this revolt through a recitation of more than fifty named villages. Inresponse to Sri Kresna Kapakisan's request for assistance, Gajah Mada sends forth from Majapahit to Bali his powerful kris, Ki Lobar (see I Wayan Warna et 
al. 1986; Wiener 1995:110). What the Babad focuses on is not an ensuing battle, but the journey of the Gajah Mada's kris from Majapahit via at least a dozen named points before reaching Samprangan on Bali. The journey of this weapon itself reinstates the power of the Balinese ruler.

Perhaps the most remarkable of these literary topogenies is to be found in the Serat Sekondhar, an eighteenth century Javanese narrative that would seem to be an attempt to incorporate and account for the European presence within a Javanese genealogical world. The text comes to an abrupt end with an invocation of "the spirits of Java, who watch over the lands ... great is their beneficent power. If they are all memorized, they will become a defense..." What follows is a litany of 142 spirits, identified by place names. This sequence of named places begins with Majapahit and moves progressively through East Java, then Central Java, along Java's north coast and on to West Java. Most of these places can be identified. The first hundred or so appear to follow a general progress whereas it is difficult to discern a geographical order to the remaining places as they are recounted (see Ricklefs 1974:403-407). Here the whole of Java, rather than just East Java as in the Nāgara Kĕrtāgama, forms the geographical template for a spirit topogeny whose memorization appears to have conferred power and protection.

\section{Varieties, Forms and Functions of Topogeny}

Even a brief survey of the topogenies one encounters among Austronesianspeaking populations suggests that it is a form that can take on various functions. As a sequence, a topogeny may focus on points of origin and termination and thus define a line of precedence. It may, as in the case of various migratory topogenies, also define a chronological succession of events and serve as an equivalent to genealogy. In such cases, a topogeny may provide the dimension of time but not the dimension of status generally associated with genealogy.

Elsewhere (Fox 1995a), I drew a general contrast between Austronesian societies characterized by "lateral expansion" and "apical demotion". Those societies with a capacity for "lateral expansion" have flexible, bilateral, largely egalitarian modes of social reckoning and generally possess sufficient territory to hive off and create new modular groups. By contrast, throughout the Austronesian world from Madagascar to Polynesia, there exist societies that are characterized by systems of "apical demotion" whereby an élite (and not necessarily the whole of the society) distinguishes itself through a process of status elevation that rigorously and automatically demotes those who become progressively distanced from a primary line of status holders. The élites in these societies rely on genealogy as a primary means of defining groups and distinguishing precedence among themselves. Societies in which groups are 
reproduced through lateral expansion can more aptly utilize topogenies to identify groups and trace continuity among them.

At best, this contrast serves to highlight differences among Austronesian populations. A majority of Austronesian populations rely on both genealogy and topogeny and many have no one form of topogeny but a variety of such forms. Transformations between topogenies and genealogies are also possible. Seen as historical documents, many elaborate Austronesian genealogies appear to have been topogenies that have been transformed into genealogies. Similarly, in those societies where the control of knowledge becomes restricted, topogenies serve as a device for the encoding of esoteric forms of knowledge.

The critical component of all topogenies are their topoi (or loci), which among Austronesians are variously referred to as "nodes", "joints", or "junctures" - using the metaphor of the growth of a plant or tree — or "gates", "halting places", or "meeting points" — using the metaphor of a journey. It is at these topoi that culturally significant knowledge is "stored". McWilliam makes this point explicit. Referring to Meto topogenies, which are expressed in ritual discourse (natoni) marked by parallelism, he notes:

Narratives such as these are in many ways only summary accounts which mark events with key verbal references that may represent tangential points for more detailed exegeses.

Topogenies thus merely provide a framework for the "placement" of more extended knowledge that can be called upon when necessary. Each place name offers the possibility for an elaboration of knowledge.

In form and function, topogenies resemble the mnemonic devices of the classic Western tradition of rhetoric and memory. Aristotle is identified as one of the founders of this tradition and the prime contributor to its different lines of development (Grimaldi 1974; Ochs 1974; Yates 1969). In his Rhetoric, Aristotle confined the use of the notion of topoi to a specification of "arguments" which he classifies by various schemes. In his Topics, however, he provided a basic statement of the relation of memory to an ordered sequence of these topoi or places:

For just as in the art of remembering, the mere mention of the places (topoi) instantly makes us recall the things, so these will make us more apt at deductions through looking to these defined premisses in order of enumeration (Topics: Bk VIII, Ch.14, 163:29-33).

As Frances Yates has shown, this passage and several others established the foundation for an intellectual tradition that flourished in the Middle Ages and has continued, in various guises, to the present (1969:42-113). This medieval "art of memory" or ars memorativa was based on an explicit formalization of 
links between "image" (or specific memory), "place" and "order", maintained through regular reiteration - all of which constitute the basic components of a topogeny. Unlike the Austronesian traditions considered in this volume, however, the Western medieval tradition removed its loci from living landscapes and located them instead in imaginary spheres that became new worlds, elaborate theatres or intricate palaces of memory.

Were one to confine consideration to forms of topogeny grounded within specific landscapes, it is apparent from the anthropological literature that topogeny is of near universal prevalence and, within the region, is of marked importance.

Jürg Wassman, for example, has provided an exceptionally striking example of topogeny among the western Iatmul of the village of Kandingei. As he stresses, critical to the recitation of the topogenies of important elder clansmen ("old crocodiles") is a "knowledge of relations and inter-connections" between "the events of primal times, the secret names of the primal beings and the totems as well as the places visited during the migration" (1991:61). As a further means to preserve the knowledge of these interconnections revealed in the topogenies, clan groups construct cords of various lengths consisting of a specific arrangement of large and small knots.

Wassman's monograph examines, in remarkable detail, a single topogeny: a mortuary performance by the Pulau clan group of a clan song-cycle that recounts the movement of the ancestral founder Walindambwi and the Palingawi crocodile through a succession of twenty sites, at which encounters occur with a "multitude of totemic objects, plants, animals and primal beings" (1991:163). The knotted cord, which serves as the mnemonic accompaniment of this topogeny, measures five metres in length and between each of its twenty large knots there are on average twelve smaller knots. The fact that much of this knowledge is esoteric and requires ambiguity and indirection in its annunciation further adds to the complexity of this construction. Wassman's account, however, provides considerable insight into the ordering of knowledge conveyed by this topogeny.

James Weiner describes a different form of topogeny in the song poetry of the Foi. Many of these songs "unfold a sequence of places" in memory of a deceased individual, often by focusing on the movement of that person as a hunter among the places he hunted during his lifetime:

... such chaining of place names in song discursively re-creates a person's life in spatial and temporal terms and preserves the sense of life's encompassing flow (1991:105-106).

Quoting Schieffelin who describes similar songs for the Kaluli, Weiner writes: 
it is possible with any song to construct a map of the region concerned, including hills, streams, gardens, sago stands, and other resources, and ... trace a history of the area (Schieffelin 1976:184).

It is of particular note that Weiner draws the inspiration for much of his analysis, including that of the Foi longhouse as an embodiment of memory, from Heidegger's notion of language as "the house of being", which is a modern-day metaphoric transformation of the classical idea of an imagined memory palace.

\section{Ambiguities and Indeterminacy of Place}

Writing about ideas of country among the Yolngu of North-East Arnhem Land in his study, Knowledge and secrecy in an Aboriginal religion, Ian Keen remarks: "Drawing a map of connections to country can give an impression of fixed, agreed areas and boundaries" (1994:101). Yet as he goes on to note, the opposite is more commonly the case. Key sites are often more important than boundaries. Ambiguity of definition and competition for control are also critical in claims to country. Keen, in particular, is concerned with the indeterminacies among complex semantic fields denoted by key categories such as "country", "group" or relation to ancestor or country among the Yolngu (1994:14).

The origin structures of the Yolngu consist of clusters of shared connections which may be extended or contracted depending on context. These connections link different social aggregates to various named countries with important named sites within them. Both groups and countries possess relations to ancestors and their actions, from whom they derive their origin and formation and thus ultimately their attributes, associations and sacra. Ceremonies are intended to trace these connections. Although in principle,

people whose countries were connected by ancestral travels formed "one group" (ba:purru wanggany, mala wanggany) with "one sacred object" (madayin wanggany) and "one ceremony" (bunggul wanggany),

as Keen explains, Yolngu regularly

discuss and argue about whether people were "one" (wanggany) and "the same" (balanya bili) or "separate" (ga:na) and "different" (wiripu); or both the same and different (1994:73-75).

Critical to this clustering of knowledge are "elbow" (likan) names. These are a "class of polysemous names, called out at key points in ceremonies" which signify "a wanggarr ancestor, a place, and a group" (1994:71). Claims to country can be made by reference to these likan names and it is the invocation of these names that propels the ceremonial enactment of a journey, along kinship lines, through a number of countries. Keen describes the performance of one such 
ceremony of the Dhuwa moiety, a Cloudy Water madayin ceremony, that lasted for thirty-three days. For this ceremony, its "power-man"

invoked the likan names of one Dhuwa country, changing the country every two days or so to include the majority of Yolngu Dhuwa groups ... the ceremony traced a journey from west to east across the northern part of north-east Arnhem Land from, and then back west along, the coast (1994:199).

There are multiple ways by which one country can be linked to other countries, thus creating what Keen calls a "string" of "links between countries and groups holding the countries, and the assertion of group identity through the possession of places and sacra" (Keen 1994:145). Relations along these strings can be both the "same" and "different" or in Keen's phrasing "similarity in overall forms ... differentiated by details" (Keen 1994:145).

Keen's work and that of Morphy (1991) provide useful models for considering Austronesian topogenies. Although few, if any, of these Austronesian topogenies may have the same densely embedded clustering of knowledge or the complex levels of secrecy and revelation of the Yolngu, they do share many formal features. Timor is criss-crossed by the topogenies of each clan or "name" group. The tracing of even a few of these topogenies across the landscape of Timor has yet to be done and an analysis of variations in recitation by different groups sharing the same name has also not been undertaken. Work of the sort that Bonnemaison has accomplished for Tanna (1987) needs to be repeated in other areas of the Austronesian-speaking world.

It is instructive to consider Rotinese topogenies in relation to those of the Yolngu. Each domain on Roti has a plethora of ritual place names. A person in any one domain will know the place names of the local domain in greater detail than those of other domains. In a recitation that traces a path through many domains, one or at best a few names will be invoked as emblematic of each outside domain, whereas the pathway through the local domain should include as many pertinent names as possible. Recitations are thus invariably the specific creations of local chanters.

Morphy has raised the question of time in relation to Australian topogenies, arguing, for example, that

place has precedence over time in Yolngu ontogeny. Time was created through the transformation of ancestral beings into place, the place being for ever the mnemonic of the event (1995:188).

This is by no means the case with all Austronesian topogenies. Some indeed may be "time-neutral" but a great variety can only be interpreted as a succession of events in time expressed according to their place of occurrence. As Renato 
Rosaldo (1980) and others have argued, this "spatialization of time" is not a denial nor an abrogation of time but a different mode of organization for memories of the past.

It is also of interest to note that among the Yolngu, body images - head, thighs, arms - are used to structure ceremonial songs (Tamisari 1997) and that tree images - root and branch - are similarly relied upon "as a symbol of the relations of one group to many others and of the distinct identity of the group" (Keen 1994:169). Much the same imagery is regularly invoked among Austronesian-speaking populations to represent relationships of similarity and difference. Tree imagery, in particular, is near universal for such purposes and one has only to read a general book, such as Corter's Tree models of similarity and association (1996), to recognize the continuing relevance of such imagery for the graphic representation of the agglomerative clustering of knowledge.

Perhaps most relevant of these images is that of the "path" or "journey" which invariably defines actions, transfers and transpositions. A comparative study of Austronesian "pathways", as an active mode for representation of relations and their transformation, should be the next step in the investigation of place, for which this volume marks a start.

\section{References}

Adelaar, K. Alexander

1997 An exploration of directional systems in West Indonesia and Madagascar. In Gunther Senft (ed.) Referring to space: studies in Austronesian and Papuan languages. Oxford: Oxford University Press.

Appadurai, Arjun

1988 Introduction: place and voice in anthropological theory. Cultural Anthropology 3(1):16-87.

Aristotle

1997 Topics: Books I and VIII. (Translated with commentary by R. Smith.) Oxford: Clarendon Press.

Barnes, Robert H.

1988 Moving and staying space in the Malay archipelago. In H.J.M. Claessen and David Moyer (eds) Time past, time present, time future: essays in honour of Professor P.E. de Josselin de Jong, pp.101-116. Dordrecht: Foris Publications.

Bender, Barbara (ed.)

1993 Landscape: politics and perspectives. Oxford: Berg.

Bloch, Maurice 
1995 People into places: Zafimaniry concepts of clarity. In E. Hirsch and M. O'Hanlon (eds) The anthropology of landscape: perspectives on place and space, pp.63-77. Oxford: Clarendon Press.

Bonnemaison, Joël

1985 The tree and the canoe: roots and mobility in Vanuatu societies. Pacific Viewpoint 26(1):30-62.

1987 Tanna: les hommes lieux. Paris: Editions de l'ORSTOM.

Boulan-Smit, Christine

1997 We of the Banyan: the Alune of Central West Seram. Unpublished PhD thesis, Department of Anthropology, Research School of Pacific and Asian Studies, The Australian National University, Canberra.

Corter, James E.

1996 Tree models of similarity and association. London: Sage Publications.

Donohue, Mark

1995 Demonstratives. Chapter 6 in The Tukang Besi language of Southeast Sulawesi, Indonesia. Unpublished PhD thesis, Department of Linguistics, Research School of Pacific and Asian Studies, The Australian National University, Canberra.

Feld, Steven and Keith H. Basso (eds)

1996 Senses of place. Santa Fe: School of American Research Press.

Fentress, J. and C. Wickham

1992 Social memory. Oxford: Blackwell.

Forth, Gregory

1991 Nagé directions: an eastern Indonesian system of spatial orientation. In O. Gron et al. (eds) Social space: proceedings of an interdisciplinary conference on human spatial behaviour in dwellings and settlements, pp.138-148. Odense: Odense University Press.

Fox, James J. (ed.)

1993 Inside Austronesian houses: perspectives on domestic designs for living. Canberra: Department of Anthropology, Research School of Pacific Studies, The Australian National University.

1995a Austronesian societies and their transformations. In P. Bellwood, J.J. Fox and D. Tryon (eds), The Austronesians: historical and comparative perspective, pp.214-228. Canberra: Department of Anthropology, Research School of Pacific and Asian Studies, The Australian National University. 
1995b Origin structures and systems of precedence in the comparative study of Austronesian societies. In P.J.K. Li, Cheng-hwa Tsang, Ying-kuei Huang, Dah-an Ho and Chiu-yu Tseng (eds), Austronesian studies relating to Taiwan, pp.27-57. Symposium Series of the Institute of History \& Philology: Academia Sinica 3. Taipei.

Fox, James J. and Clifford Sather (eds)

1996 Origin, ancestry and alliance: explorations in Austronesian ethnography. Canberra: Department of Anthropology, Research School of Pacific and Asian Studies, The Australian National University.

Grimaldi, William M.

1974 The Aristotelian Topics. In Keith V. Erickson (ed.) Aristotle: the classical heritage of rhetoric, pp.176-193. Metuchen, NJ: The Scarecrow Press.

Hefner, Robert

1985 Hindu Javanese: Tengger tradition and Islam. Princeton: Princeton University Press.

Hirsch, Eric and Michael O'Hanlon (eds)

1995 The anthropology of landscape: perspectives on place and space. Oxford: Clarendon Press.

Keen, Ian

1994 Knowledge and secrecy in an Aboriginal religion. Oxford: Clarendon Press. Morphy, Howard

1991 Ancestral connections: art and an Aboriginal system of knowledge. Chicago: Chicago University Press.

1995 Landscape and the reproduction of the ancestral past. In Eric Hirsch and Michael O'Hanlon (eds) The anthropology of landscape: perspectives on place and space, pp.184-209. Oxford: Clarendon Press.

Munn, Nancy D.

1970 The transformation of subjects into objects in Walbiri and Pitjantjatjara myth. In R.M. Berndt (ed.) Australian Aboriginal anthropology, pp.140163. Nedlands: University of Western Australia.

Myers, F.R.

1986 Pintupi country, Pintupi self: sentiment, place and politics among Western Desert Aborigines. Washington, DC: Smithsonian Institute Press.

Ochs, Donovan J. 
1974 Aristotle's concept of formal topics. In Keith V. Erickson (ed.) Aristotle: the classical heritage of rhetoric, pp.194-204. Metuchen, NJ: The Scarecrow Press.

Parmentier, Richard J.

1987 The sacred remains: myth, history and polity in Belau. Chicago: University of Chicago Press.

Pigeaud, Theodore G.Th.

1960 Java in the 14th century: a study in cultural history. 5 vols. The Hague: Martinus Nijhoff.

Ricklefs, Merle C.

1974 Jogjakarta under Sultan Mangkubumi, 1749-1792: a history of the division of Java. London: Oxford University Press.

Rosaldo, Michelle Z.

1980 Knowledge and passion: Ilongot notions of self and social life. Cambridge: Cambridge University Press.

Rosaldo, Renato

1980 Ilongot headhunting, 1883-1974: a study in society and history. Stanford: Stanford University Press.

Rumsey, Alan

1996 The personification of social totalities in Pacific oratory. Paper presented at the 1996 American Anthropological Association Meetings.

Schieffelin, Edward L.

1976 The sorrow of the lonely and the burning of the dancers. New York: St Martin's Press/St Lucia: Queensland University Press.

Stanner, W.E.H.

1964 On Aboriginal religion. Sydney: University of Sydney.

Strehlow, T.G.H.

1970 Geography and the totemic landscape in Central Australia: a functional study. In R.M. Berndt (ed.) Australian Aboriginal anthropology, pp.92140. Nedlands: University of Western Australia.

Sudo, Ken-ichi

1996 Rank, hierarchy and routes of migration: chieftainship in the Central Caroline Islands of Micronesia. In James J. Fox and Clifford Sather (eds) Origin, ancestry and alliance: explorations in Austronesian ethnography, pp.55-69. Canberra: Department of Anthropology, Research School of Pacific and Asian Studies, The Australian National University. 
Tamisari, Franca

1997 Body, vision and movement: in the footprints of the ancestors. Unpublished paper. University of Sydney (19 February 1997).

Toren, Christina

1995 Seeing the ancestral sites: transformations in Fijian notions of the land. In Eric Hirsch and Michael O'Hanlon (eds) The anthropology of landscape: perspectives on place and space, pp.163-183. Oxford: Clarendon Press.

Vischer, Michael P.

1992 Children of the black patola stone: origin structures in a domain on Palu'é Island, Eastern Indonesia. Unpublished PhD thesis, Department of Anthropology, Research School of Pacific Studies, The Australian National University, Canberra.

Wassman, Jürg

1991 The song to the flying fox. Boroko: Cultural Studies Division, The National Research Institute. (Translation of Der Gesang an den Fliegenden Hund. Basel: Basler Beiträge zur Ethnologie: 22. 1982.)

I Wayan Warna, Ida Bagus Gede Murdha, Dewa Gede Tjatera, Ida Bagus Maka and Ida Bagus Sinu (eds)

1986 Babad Dalem: Teks dan Terjemahan. Dinas Pendidikan dan Kebudayaan Propinsi, DATI I, Bali.

Weiner, James F.

1991 The empty place: poetry, space and being among the Foi of Papua New Guinea. Bloomington: Indiana University Press.

Wiener, Margaret J.

1995 Visible and invisible realms: power, magic and colonial conquest in Bali. Chicago: University of Chicago Press.

Williams, Nancy

1986 The Yolngu and their land: a system of land tenure and the fight for its recognition. Canberra: Australian Institute of Aboriginal Studies.

Yates, Frances A.

1969 The art of memory. London: Peregrine Books. (First published London: Routledge \& Kegan Paul, 1966.) 



\section{Chapter 2. The Water That Blesses, The River That Flows: Place And The Ritual Imagination Among The Temanambondro Of Southeast Madagascar $^{1}$}

\section{Philip Thomas}

\section{The Place-Ness of Water}

Not long after beginning fieldwork in the village of Manambondro in coastal southeast Madagascar, I was called one evening to the house of the "headman" of the house-group in which I was domiciled. Gathered together there in the encroaching gloom of dusk were several men, to whom the purpose of my visit was being explained. When one man heard that it was my hope to learn to speak the dialect of Malagasy spoken thereabouts he interjected to the effect that I would learn the language as quickly and easily as I drank the water of the Manambondro River.

As I did not see a great deal of significance in it at the time it was made, I failed to follow up this intriguing remark, which linked a particular aspect of local ways of doing things (fomba), dialect, to a feature of the landscape, the river. In time, however, I came to realize that the Manambondro River and its water were important elements in what, to paraphrase Fernandez (1982), I have chosen to call the Temanambondro "ritual imagination". The water of the Manambondro is said to possess "sacred efficacy" (hasy), and is used in a variety of rites of blessing and purification. In this regard Temanambondro rituals appear simply to be a variant of more widespread practices in Madagascar, in which water is employed as a vehicle of blessing. However, as I will argue, while water itself may have great ritual significance, just as, if not more, important is the place where that water comes from.

Water figures in a large number of ethnographic accounts of rituals among the peoples of Madagascar. Every ten years or so the Sakalava of Menabe on the west coast bathe the relics of their deceased rulers in the river that runs through the centre of their domain (Nérine Botokeky 1983), a rite similar to those of other Sakalava polities to their north (Feeley-Harnik 1991b:102-103). Across the island in the forests of the eastern escarpment a similar practice is to be found among the Tañala who themselves say that this custom originated in the southwest of the island (Beaujard 1983a:317-319, 1983b:332-337). Here, the relics of former 
rulers are taken each year and submerged in water at the confluence of two rivers into which runs the blood of a sacrificed bull.

These rites, involving the purification of ancestors, are known as "baths" (fandroana), and are similar in many respects to rites of the Tanosy and Temoro of Madagascar's east coast and the Merina of the central highlands, although here it is living rulers who are bathed, rather than the remains of their dead predecessors (see Molet 1956). Although the rite is now rarely practised, among the Temoro the "bath" was an annual event which marked the beginning of the new year, and involved the "ruler" (mpanjaka) bathing in the water at the mouth of a river (Chandon-Moet 1972:52; Rolland 1984:118-120). In Imerina the ritual of the royal bath similarly marked the transition from one year to the next, and involved rulers bathing themselves in water mixed with earth taken from the tomb of their ancestors, water which was later used for the blessing of the rulers' subjects (Bloch 1987). That the bathing of royal relics, like the ritual of the bath, has also to do with blessing and fertility in its widest sense is clear from two accounts of its origin (Nérine Botokeky 1983:212; Beaujard 1983b:332).

We can begin to look more closely at the ritual significance of water in these and other rites by considering Maurice Bloch's analysis of Merina blessing (Bloch 1986). Blessing, Bloch contends, underlies Merina practices of secondary burial, circumcision and the royal bath, and is centrally important to Merina notions of descent and descent-groups, or demes (1986:39-47). In the Merina dialect the term for blessing suggests vividly what it involves, for it translates as "the blowing on of water", and during the act of blessing the male elder who administers it blesses the supplicants with water by blowing and spraying it over them.

There is however a certain ambiguity about the source of the fertility that is diverted in Merina blessing, an ambiguity associated with ideas about land. According to Bloch, "water is associated with the unappropriated fertility of the land" (1986:41), an idea which contrasts with a different notion of the fertility of the deme and its appropriated land, an opposition which is represented in terms of the tomb. Being the containers of the previous generations of the deme, tombs are the source of blessing and fertility. Demes are also eternally associated with particular tracts of land, with tombs being the very evidence of this association. Yet Merina recognize that they themselves are not true autochthons of the lands they occupy, lands which were once occupied by others whom the Merina conquered. And it is these true autochthons, the Vazimba, whom Merina associate with notions of a "wild" fertility found outside the authority of the deme and above all associated with water. Merina blessing then is a canalization of the "wild" power of the true owners of the land, here represented in water, through the words and mouths of the land's current occupiers (1986:41-43). 
Nowhere is this canalization more graphically realized than in the practice of placing water on a tomb prior to its use in blessing.

But whilst Merina blessing involves placing water on tombs, in his account of the royal bath Bloch also makes clear that the water used in the ritual came from a particular place or places, lakes in which Vazimba queens were said to have been buried (Bloch 1987:280). There appears therefore to be something rather particular about the source of the water for blessing, and it is this dimension of water which concerns me here: its association with particular places. For whilst one may analyse the ritual significance of water in terms of its use in blessing, or its association with "rulers" and royalty (Beaujard 1983a), what is especially striking about the use of water in many Malagasy rituals is that it is an important element in making rituals place-specific. Royal baths and the bathing of relics, for example, occur in particular places, or, in the Merina case, use water drawn from particular places. Once one sees water not simply as a vehicle for blessing, but as a substance associated with particular places, it becomes clear that water courses and sources are part of a symbolic geography and ritual topography among many Malagasy peoples. Water thus appears significant not simply in and of itself, but as part of local cartographies of the sacred, and nowhere is this more so than in the east of Madagascar, where rivers, and in particular their confluents and embouchures, figure as focal places for a variety of rites.

Among Betsimisaraka of the northeast, for example, Cotte reports that springs, rapids and waterfalls are "places of cult", and that "spirits" inhabit river confluents (Cotte 1947:62, 161, 172). Similarly, in the southeast of the island male circumcision rituals involve the use of water as a vehicle of blessing and healing, and reports of these reveal that the source of water, often a particular river or spring, is itself of great importance (Rajohnson 1908:178; Deschamps and Vianès 1959:22-23, 60; Chandon-Moet 1972:105-106; Beaujard 1983a:314). Finally, and perhaps most striking, is a rite found widely along the east coast, and which accords as much, if not more, importance to the river as it does to the water it contains. This rite is performed to clear the mouth of a river which has become barred by a sandbank, or when other inauspicious events signal that the river needs purifying (Cotte 1947:150-152; Deschamps and Vianès 1959:21，79; Chandon-Moet 1972:67-68; Rahatoka 1984:77-79). Among Temanambondro the rite is known as a sao-binañy, "blessing of the river mouth", and is said to "cleanse the river" (mampadio renirano) and thus return "sacred efficacy" (hasy) to the water it contains.

The importance of ideas regarding rivers among peoples of the east coast was in fact long ago noted by Ralph Linton, who pointed out that peoples of the region often have "a sacred river into which the umbilical cords of children are thrown" (Linton 1928:372). Only if this has been done, he said, can a person be 
buried in the group's tombs, structures which are themselves usually built near the sacred river. Linton also noted that when a people moved into a new locality they baptized and named the river there with water drawn from the sacred river from where they had come (1928:373). Whilst drawing on a limited range of data, Linton's remarks are highly suggestive in the light of subsequent ethnographic research.

More recently, in an analysis of the importance of water in Tañala political symbolism, Philippe Beaujard (1983a:313-314) has pointed to the contrasting importance accorded to deep pools and whirlpools in the central highlands (of which the lakes of Vazimba queens are one example), and river mouths and confluents on the east coast (see also Hurvitz 1986). Whilst one may feel sceptical regarding Beaujard's ideas about religious heritages and syncretism, one point he makes is worth following up:

It appears ... that the apparent retracing of water to its source in the whirlpool of a confluent or deep river pools may be the basis of a religious attachment of rulers to these places (1983a:314).

Unfortunately Beaujard does not develop this interesting idea, neither in terms of ideas regarding sources and origins, nor of what is involved in attachment to places. However, an analysis of the significance of water in Temanambondro ritual reveals not only the fundamental importance of rivers, but also that these water courses are conceptualized as a "source" or "origin", and that they are an important part of what attaches people to place. Furthermore, the points noted by Linton about umbilical cords, tombs and the "baptism" of new localities, are related to ideas about "sources", "origins" and connectedness to place, for each participates in a play of images involving the organizing metaphor of "roots". And it is to rivers, "roots" and the Temanambondro that I now turn.

\section{Temanambondro: A Riverain People}

Those people who refer to themselves as Temanambondro currently occupy the lower reaches of the Manambondro, Isandra and Iavibola Rivers, which lie a little to the south of the Tropic of Capricorn in southeast Madagascar. My own fieldwork was principally carried out in the lower Manambondro Valley, which during the early 1990s was home to around 8,000 subsistence agriculturalists. Although many people produced small quantities of cash-crops, principally coffee and cloves, the vast majority of people's livelihood centred on the growing of wet rice, cassava and sweet potato for household consumption.

The significance of the name Temanambondro will become clear below, but it does not figure among the eighteen so-called "ethnic groups" or "tribes" of Madagascar, and here the Temanambondro disappear under the appellation Tesaka (or Antaisaka in the official dialect of Malagasy). In fact, a previous ethnographer of the latter people has referred to the Temanambondro as one of 
a small number of "assimilated tribes" of the Tesaka (Deschamps 1936:79). But, although they are socially and culturally speaking very similar to these northern neighbours (as indeed they are to virtually all the peoples of southeast Madagascar), Temanambondro claim different historical and geographical origins to the Tesaka, and do not think of themselves as "assimilated" at all.

Temanambondro are a ritual polity comprising a number of named "kinds" or Ancestries (karazana), each of which has its own tomb (kibory); Ancestries are in turn divided into one or more "house-groups" (trañobe, lit. "big" or "great houses"). Ancestry identity, and thus house-group membership, is traced through the "father", although I prefer not to call either grouping "patrilineal" as I feel this tells us little of any consequence. Although neither Ancestries nor house-groups are corporate in the full sense of the term, both groups are at their most cohesive in the context of ritual, especially funerals. Furthermore, whilst Ancestries are not localized groups, by and large house-groups comprise a distinct group of houses arranged around a small plaza which is the group's ritual and often physical centre. Finally, Ancestries and house-groups are neither "exogamous" nor "endogamous", nor is either grouping linked to others by a system of "alliance". In fact, these groups are not the basis by which marriages are made, although Temanambondro have a preference for marrying people to whom they are in some way related. ${ }^{2}$

Temanambondro villages may contain one or more house-groups, and one or more Ancestries. The one with which I am most familiar is Manambondro village, by far the largest in the region, and home during the fieldwork period to around 3,000 people, divided into some fifty-eight house-groups of eleven named Ancestries. The name of the village, however, has an interesting history, for the very word Manambondro is to some extent an important "container" (Casey 1987:186) of Temanambondro collective memory. The importance of the relationship between place and memory has occasionally been remarked on (for example, Relph 1985; Casey 1987), and nowhere is this more apparent than in the narrative that recounts the origins of the Temanambondro, a story which reveals people's connectedness to place through a body of water, the river that flows, and the source of the water of blessing.

This story tells how the earliest arrivals of the Temanambondro journeyed from the region of Ikongo in the eastern rainforests of Madagascar, some 200 $\mathrm{km}$ north of their present home, a region they appear to have left more than 350 years ago. In the region of Ikongo lived a man named Andriamaroary, whose village was located alongside a river named Manambondro. In the wake of a large storm a group of people led by Andriamaroary left their home village, and with them they carried a gourd containing some "ancestral water" (ranon-drazana) from the Manambondro River. The group journeyed south, stopping at various points on the way, until they finally came to the mouth of a large river. There, 
a sign satisfied a "diviner" (ombiasy) among the group that here was the place to settle, and Andriamaroary agreed. However, soon after another sign appeared, this time of habitation upriver, and so Andriamaroary and his followers set off to investigate. Not far away they found an island in the middle of the river and on it a half-deserted village, occupied by among others a people known as Ramañera. Fighting ensued and the newcomers triumphed. Andriamaroary decided that he and his followers too would live on this island, which still lies in a river whose old name no one remembers, for after making his decision Andriamaroary took the gourd that had been carried from the north, and emptying the contents into the water flowing past his feet, he named the river after the one they had left behind them, Manambondro. ${ }^{3}$

So the name has remained, memorial testament to the ancestral origins of the arrivals from the north, although the inhabitants of the island were moved to the mainland around 1905, not long after the imposition of French colonial rule. The village that was created as a result of this forced relocation is also named Manambondro, after the river that flows past it, but as one elder insisted, "it is not the village but the river that is called Manambondro" (tsy ty tana ty fa ñe renirano atao hoe Manambondro). The people who live here then, and in other villages within the domain of the polity that was established here, are Temanambondro, literally "people of the Manambondro River".

The very act of naming the river reveals how central this water course was in the constitution of the ritual polity established by Andriamaroary and later extended by his successors. On the journey from the north Andriamaroary had been accompanied by his daughter, as well as by her three sons, between whom he divided the polity he had founded. From the daughter's three sons stem the former "ruling" (andriana) Ancestries of the Temanambondro polity, each of which ruled a separate domain. The daughter's eldest son established himself and the Andratsimaniry Ancestry on the lower Isandra and Iavibola Rivers, while the second eldest founded the polity ruled by the Andriatsiazomosary in the middle Manambondro Valley. These two domains were to some extent autonomous ritual polities, but continued to recognize the superior status of the polity ruled by their youngest brother and the Andonakavaratra, centred on the island of Antokonosy on which Andriamaroary had chosen to settle.

Those ruled by these "ruling" Ancestries fell into two ranked groups of named Ancestries, some of which had accompanied Andriamaroary on his journey, whilst others arrived at later points in time. Of higher status were those Ancestries known as "children of rulers" (anak'andriana), while below them was a large group of subject Ancestries, including the Ramañera, the original inhabitants of the land.

The power and authority of the "ruling" Ancestries was principally constituted in terms of ritual agency, and through other forms of symbolic 
practice such as consumption and display. The hierarchical division of these polities, with "children of rulers" holding intermediate status between "ruling" and subject Ancestries, lasted until the last decade of the nineteenth century, when the subject peoples which rose up against the "ruling" Ancestries and their "children". In the aftermath of these events, many, although not all, of the practices that signalled the dependent status of subject Ancestries were appropriated by the former subject groups, who gained a great deal of politico-ritual autonomy. On the lower Manambondro, the subject groups which rose up combined under the name Zafimananga, a name they still use to identify themselves as a political entity. Zafimananga is opposed in people's minds to Andrafolo, the name used to refer to the Ancestries formerly holding the status of "rulers" and "children of rulers" who now live in Manambondro Village.

Despite the demise of the ritual polity in its old form, Temanambondro continue to recognize themselves as a distinct "kind" of people in part through their ritual practices, as well as through the place they live in. In fact, place and ritual are mutually constituted in many ways, for just as place can be constituted ritually, so too are rituals defined by the places in which they are performed. For Temanambondro this mutual constitution of place and ritual involves a further element, a constant feature of the environing landscape and a focal image in people's sense of place: the Manambondro River.

\section{Life, Death and the River}

Since the days of Andriamaroary the Manambondro River is said to have gradually grown in size. Whereas it was once possible to reach the island of Antokonosy from the mainland by crossing a bridge made from a felled tree, now it is only possible to do so by canoe. At its largest the river is some $200 \mathrm{~m}$ or so wide, and the flow of the water often so slow as to be virtually imperceptible. Most of the villages of the lower Manambondro Valley lie close to the river, and people's everyday lives are intimately entwined with this majestic and slow-moving body of water. People descend to its banks several times a day to draw water for cooking and drinking, to wash themselves and do their laundry, and to embark in their canoes for their rice-fields and other agricultural lands which either lie close to the river or to one of its tributaries.

Besides being a constant presence in people's everyday lives, as the story of Andriamaroary highlights, the river is also an important place in ritual terms, and an "elemental image" and "organizing metaphor" (Fernandez 1982) of the ritual imagination. The Manambondro is referred to as the "ancestral water" (ranon-draza) of the Temanambondro, and is an example of what Linton referred to as a "sacred river", although the term is somewhat misleading if understood in an absolute sense. In fact the sacrality of water is only evident in ritual contexts, whilst in other situations it is not (see also Smith 1987:103-106), and ritual contexts aside, people do not treat it with awe or reverence. However, the 
water that many people drink and wash in is also said to possess "sacred efficacy" (hasy), and features in a number of different rites. In marriage, for example, river water is used to make a paste that enables the spouses to "take away the taboo" (mangala fady) that exists between them. River water can also be drunk as a "cure" (hetry) when someone is challenged to a truth ordeal (tange), and during one ritual I witnessed that was aimed at "cleansing" (mampadio) a man of the "bad things" (raha ratsy) he had seen while serving in the Malagasy army, he was anointed with the blood of a sacrificed zebu, an act followed by a ritual bath in the river. The Temanambondro term for blessing also reflects the importance of water, for these acts are known as fafy rano, "sprinkling water". However, the most formal blessings performed during large rites involve the use of locally brewed sugar-cane alcohol, although in the past a mixture of honey and river water was said to have been used.

The water of the Manambondro River, however, is not simply a source of "sacred efficacy", for as the story of Andriamaroary indicates, it is also an important spatial image of Temanambondro self-definition, and thus an elemental image in people's sense of place. Indeed, the river frames people's lives and experience, not just on the everyday level, but also more dramatically in ritual terms, and in particular through its place in the rituals which accompany birth and death.

At birth the placenta (razana, also meaning "ancestor") of the newborn child, said to be the child's "elder sibling" (zoky), is taken and interred in the grounds of the house-group of the child's "father". A few days later, along with clippings from the first cutting of the child's hair and nails, the child's umbilical cord (foitra) is put in a small piece of cloth, which is then tied and weighted with a stone. Shortly before dawn on an auspicious day, the child's "father" takes the weighted bundle to the "throwing-away-place of the umbilical cord" (fañariana tadim-poitra), and there he throws it a long way out into the middle of the river after an invocation that places all Temanambondro in a spatio-temporal relationship to the river from which they take their name.

We announce to you ancestral water the throwing away of the umbilical cord of R. Whether having gone north, gone south or gone west then [if s/he] becomes attached to the land there only you water of the Manambondro will s/he not forget. ${ }^{4}$

No matter where they are born, the navel cord of each Temanambondro returns to be thrown into the river of its ancestors, and if this has not been done then it is said that the person will be denied burial in the tomb. ${ }^{5}$

What is especially significant here is that the rite which in part makes a person Temanambondro through defining personhood in relation to place, the river from which the Temanambondro take their name, and Temanambondro 
as a whole, are all referred to as "children" (taranaka) of the Manambondro River. Furthermore, the rite anticipates the person's death and burial, another ritual which is a defining feature of personhood, for the "throwing-away-place of the umbilical cord" is immediately alongside the "harbour-place of the corpse" (tsirañam-paty) from where the person will leave for interment in the tomb after death. In fact this place, and the river and its waters, are especially prominent in Temanambondro rites of burial and commemoration.

When a person dies, the body is returned to the "female house" (trañom-bavy) of the house-group, and there the corpse is prepared for burial. Before it can be dressed in clothes and enveloped in various shrouds, however, the corpse must be washed. Water for this is drawn from the river at the "harbour-place of the corpse", and it is here also that the dead are given their "final farewell" when they leave behind their living relatives in the village for burial in the tomb downstream. Rarely more than a day after death, the corpse is taken from the "female house" and carried on a bier down to the "harbour-place of the corpse". Once there the corpse and bier are placed in a large dugout canoe which, when it leaves the bank to the sound of the cries of the mourners, heads out into the mid-stream, the place where the person's umbilical cord had been thrown shortly after their birth. Then the canoe turns to head off silently downstream, gently paddled toward the tomb that lies near the mouth of the river.

After they have been buried (the period of time varying from one or two days to several years), the dead person is commemorated in a second rite (takombato), the culmination of which is the placing of commemorative objects in a memorial ground adjacent to the tomb, the point at which the dead achieve ancestorhood. Temanambondro commemorate their dead in the form of a carved wooden post to which the horns of sacrificed cattle are attached, and with a standing-stone often less than a metre in height. Prior to the rite itself the wood and stone needed are sought outside the village. Men wandering "in the forest" $(a \tilde{n}-a l a)$ or working "in the bush" (añ-ahitra) often make note of any rocks they see which are likely to serve well as standing-stones. Although these are nowadays usually left where they are found until they are needed for a commemoration, it was previously customary to take a stone to the river, one of its tributary streams, or to the "harbour-place of the corpse" and leave it there until required.

A similar practice is entailed in obtaining the wood for the carved post, or teza, a name which also refers to the class of hardwoods from which the post is made. Although sometimes fashioned from old hardwood house-posts, some teza are still made from living wood cut from the forest following the customary method of doing so. A group of men depart for the forest and spend two or more days away cutting trees that are then brought back to the village. Until the point arrives when they are to be fashioned into memorial posts, when the "head" of 
the teza has carved into it an image of the river-dwelling crocodile and a gourd, these cut trees are left in the river, tied to the river bank at the "harbour-place of the corpse".

Just as the disposal of the umbilical cord anticipates the place from which the person will one day leave for burial, the place where the stone and tree are kept also anticipate their own departure at the close of the commemorative rite. After the stone has been danced into the village and taken to the dead person's house-group, and after the cut tree has been fashioned into the memorial teza, they are both brought in an exuberant dancing procession to the "harbour-place of the corpse" and loaded onto canoes that take them down-river to be erected alongside the tomb in which the person they commemorate was buried. Their point of departure and the route taken as they travel reproduces that of the corpse they represent in so many ways. ${ }^{6}$

Temanambondro are people of the Manambondro River, and the rites that mark the beginning and end of life vividly demonstrate this fact, for these rites, which are crucially important in the constitution of personhood, are performed in relation to the river. To have had one's umbilical cord disposed of in the Manambondro River, and to be part of an Ancestry which has a tomb at the mouth of the Manambondro River in which one will be buried, is part of what it is to be Temanambondro. The river is important then, not just as a source of water possessing "sacred efficacy", but also as the place through which Temanambondro are constituted as full and moral persons, both in life and in death. In addition to its significance in the making of persons, the river is also of great importance in the creation of the Temanambondro as a polity, a collectivity of named Ancestries, for the polity is itself constituted through relations defined in terms of place, or more particularly, in relation to the river.

\section{The River and the Polity}

The story of Andriamaroary's journey highlights an important "origin" (fototra) of the Temanambondro polity, the place from which Andriamaroary and the gourd of water came. Yet it is also recognized that Ancestries that originate from among those who followed Andriamaroary are in a minority among the Temanambondro as a whole, and that those who arrived in the region after Andriamaroary came from different places, and therefore have different historical and geographical "origins". What unites the Temanambondro, however, is not their "origins", although like those of the Ancestries who accompanied Andriamaroary, most arrived from the north, but the place in which Temanambondro now live. "Everyone comes from somewhere different", remarked one man, "but the place brought them together" (samby mana ñe viany aby $\tilde{n}^{\prime}$ olo, fa ñe faritra nampitambatra anazy), and those places which are seen as especially significant in bringing people together are the Manambondro River and its embouchure, as well as the tombs which are located there. 
The idea of unity between people of different "origins" being created through the river was clearly articulated to me by a number of people. As two different men put it, the Manambondro River is the "great trunk" (fotora be), it is "the root which is the basis of what makes the Temanambondro Temanambondro" (ñe fototra iorenany maha-Temanambondro ñe Temanambondro). The river unites people under one name - Temanambondro - and defines them as "one kind of people" (karazan'olo raiky). The river mouth is also important as a place which unites Temanambondro: "there is a state of relatedness between people [who] share a river mouth" (pihavana ñe olombelona mana vava rano raiky), one man told me, "the embouchure makes people one" (miray olo ñe vinñay). In fact the lands occupied by Temanambondro are crossed by more than one river, but the Manambondro takes precedence among these, both because this is where Andriamaroary poured the gourd of water and because at its mouth lie the tombs and memorial grounds of most Temanambondro Ancestries.

Although Temanambondro are united through the river, its embouchure and their tombs, these "houses of the ancestors" (trañon-drazana) also signal divisions among them, divisions of Ancestry and hierarchy. Here the unity of the "great trunk" gives way to differentiation, idiomatically represented in terms of "branches": as one man put it, employing a common turn of phrase to stress both unity and difference in the same context, "we [Temanambondro] have only one root but everyone has their own branch" (fototra raiky avao ahay fa samby mana ñe sokazany). The use here of the image of "branches" can be understood in different ways. Firstly, it can be seen to refer to the fact that although all Temanambondro share one "root" (fototra) in the Manambondro River, various Ancestries have different historical and geographical "origins" (fototra), the places from which they migrated before coming to the Manambondro. Secondly, these "branches" refer to a more local articulation of difference, one that embodies difference in the architectonics of ritual spaces and places.

Although the rites performed at the "throwing-away-place of the umbilical cord" and the "harbour-place of the corpse" are part of what makes a person Temanambondro, thus creating unity and identity among people through their relation to the river, the exact place where the rites are performed also differentiates persons in terms of Ancestry. Each Ancestry has its own "throwing-away-place of the umbilical cord" and "harbour-place of the corpse", although in some cases these are shared with another Ancestry. Thus the rites of birth and death take place at different places along the river, according to the person's Ancestry identity.

This differentiation of Ancestries through ritual places is also to be found in the spatial positioning of tombs. Although each Ancestry has its own tomb at the river mouth, places which are themselves talked of as "roots" (fototra) of an Ancestry, their spatial arrangement is an embodiment of hierarchical relations 
within the polity, both past and present, highlighting divisions which Temanambondro talk of in terms of "branches" (sokazana).

The hierarchical division of the polity between Ancestries who were "rulers", "children of rulers" and subjects was concretized in the spatial location of tombs, as was the succession of Ancestries who arrived after the polity had been founded. Temanambondro hierarchy is most graphically realized in the spatial positioning of bodies and objects, ranging from where people sit in houses, through the lay-out of house-groups, to the positioning of tombs (see Thomas $1995,1996)$. In such contexts the spatial articulation of hierarchy is principally played out through the cardinal points: north and east are respectively "above" (ambony) and therefore superior to south and west, themselves "below" (ambany).

An aerial view of the mouth of the Manambondro River would reveal, in small open spaces cleared from the surrounding forest, a myriad of roofed structures arranged in clusters and oriented to the cardinal points. These are the tombs of Temanambondro Ancestries, located on both the north and south bank of the embouchure. The tombs of the Ancestries who accompanied Andriamaroary are to be found on both sides of the river, with the tombs of "rulers" and "children of rulers" found to the north, and the tombs of subject Ancestries to the south. The tombs of Ancestries who arrived later, known as "people who came after" (olo avy tafara) and including both "children of rulers" and subject groups, are all found to the south of the embouchure. The positioning of tombs therefore gives concrete spatial expression to relations of hierarchy and temporality. The highest ranked and first arrived Ancestries are found to the north of those of the same rank who arrived after, and the northernmost tomb on the north side of the river is that of the former "ruling" Ancestry on the lower Manambondro.

Relations of hierarchy are played out in the context of death in another way too. Although many of the forms of ritual agency, consumption and display which differentiated Andrafolo from subject Ancestries on the lower Manambondro River are no longer practised, Andrafolo and Zafimananga take different routes around Antokonosy, the island where Andriamaroary and his followers first settled, when taking corpses and memorial objects down-river to the tombs. In keeping with the spatial ordering of hierarchy, only Andrafolo may pass the island "at the great head" (an-dohabe), that is to the east, while Zafimananga must pass to the west, literally "at the door" (am-baranga). ${ }^{7}$

Whilst the river itself unites the Temanambondro, "making them one", places, objects and trajectories associated with umbilical cords, tombs, corpses and memorial objects also highlight divisions within the polity, differentiations articulated in relations to the river. Thus although the river is the "root" and "great trunk" of the Temanambondro, the "throwing-away" and 
"harbour-places", tombs and routes taken by canoes to the tombs graphically illustrate the idea that each "root" and "trunk" has its "branches".

\section{The "Roots" of Place}

While accepting that the inclusion of Madagascar in the Austronesian world is a classification fraught with complication, what is perhaps most striking about Temanambondro ideas pertaining to the river in the context of comparison within this region is the frequent use of images of "origins", "roots" and "trunks", and their proliferation and differentiation as "branches". As Fox (1993:16-23) has recently noted, throughout much of the Austronesian-speaking world, and particularly in Southeast Asia, there is a concern with "origins" of various sorts which "constitutes a fundamental epistemological orientation and takes on a remarkable variety of forms" (1993:16-17). This concern manifests itself in such things as the complex and sometimes poetic narratives of geographical and historical origins of peoples and their movement across the landscape, and in the wide range of botanical metaphors, such as "roots" and "trunks", and their outgrowth in the form of "tips", "leaves", "flowers" and so forth, which are used to represent a variety of social, spatial and temporal relations. Furthermore, many of the words used to express these ideas in Austronesian languages are cognate terms containing the syllable $f u$ or $p u$ (Fox 1980:14; Errington 1989:205 passim).

Temanambondro idioms and images appear to be related to this widespread Austronesian phenomenon, both at the metaphorical and linguistic level. A wide range of botanical metaphors are employed in the context of marriage, where human fertility is likened to the growth and reproduction of plants, as well as in idioms of relatedness, where, for example, the person is said to have "eight sides" or "branches", of which that of the "father" is referred to as the most important "root", the teña fototra (Thomas 1996). More significant in the present context, the river itself is imagined through a multitude of images involving "roots" and "trunks". The Manambondro River to the north is spoken of as the "origin" (fototra) from which Andriamaroary came, while the river into which Andriamaroary poured the gourd of water and named Manambondro is said to be the "great trunk" (fotora be) and the "root which is the basis of ... the Temanambondro" (ñe fototra iorenany maha-Temanambondro ñe Temanambondro). At the mouth of this river lie the tombs, themselves the "roots" (fototra) of the various Ancestries, while into the river is thrown the "root of life" (fototra ñe fieñana), the child's umbilical cord (foitra). ${ }^{8}$

These terms, which would seem to represent a Temanambondro variant of the concern with "origins", comprise an important set of idioms and images through which Temanambondro imagine "being-in-place" (Casey 1993) as a state similar to the rootedness of plants. Temanambondro are multiply rooted in place: through bodies, buildings, and the environing landscape; through placentae 
and umbilical cords, houses and tombs, and through the slowly flowing Manambondro River. Furthermore, this multiple-rootedness is what makes being-in-place a being-in-the-world-through-relations-with-others, with parents, with those of a person's Ancestry, and with other Temanambondro. Aspects of personhood, and personal and collective identities are therefore constituted through various "roots", themselves in turn rooted in places.

It appears therefore that an important aspect of Temanambondro ritual practice is the process of creating place, and of placing people in place, both processes involving the creation and placing of "roots". This at least would appear to lie behind the naming of the river, the disposal of the umbilical cord, and the burial and commemoration of the dead. The first rite involves the creation of a "root", while the latter two relate people to this "root" through the corporeal "roots" of their own bodies, and through tombs, the "roots" of Ancestries.

It would be a mistake, however, to assume that being-in-place through "roots" implies stasis, permanence or absolute fixity. For while "roots" may be part of the way people imagine connectedness to place, like many of the plants Temanambondro cultivate and to which they liken many aspects of social relations, they can be "cut" and transplanted to new places. In fact, a place with "roots" may be the starting point of migration to other places, just as it may be a place into which people have migrated and settled, and both places are referred to as fototra, both "origin" and "root".

From Beaujard's (1983b:35-49) account of Tañala migration stories it would seem that Andriamaroary's own ancestors were immigrants to the region in the north named Manambondro. In the shape of Andriamaroary and his followers these people moved on again, migrating south until they settled on the island of Antokonosy and named the river in which it stood after that from which they had come. More recently still, this migratory process has occurred once more. In the wake of a violent encounter in 1904 between colonial forces and Temanambondro insurgents that marked the end of an uprising against French colonial rule, a number of people from villages on the lower Manambondro and Isandra Rivers left their lands and fled south, finally settling some $150 \mathrm{~km}$ away, a little to the west of the town of Fort Dauphin. Now fully "attached to place" (tama) and rooted in their new lands, up until the mid-1960s these émigrés returned the bones of their dead for final interment in the tombs at the mouth of the Manambondro River, the "origin" place from which they had migrated. This they no longer do, having permanent tombs and memorial sites in the lands they have settled. In founding these places of burial and commemoration they had to perform the rite of "cutting the root" (fira fototra), for only then could they independently establish themselves in the place they had moved to. In "cutting the roots" that connected them to one place, they were able to transplant them to another. 
Thus the creation and cutting of "roots" is part of a spatio-temporal process. A people establish themselves in a place and put down "roots", naming the river there, and inscribing themselves on the landscape through working, building on and burying in the land. At some later date they move on and establish new "roots" in new places, "cutting" the roots that connect them to the old. But as with the roots of the cultigens they transplant, the "roots" people make in places take time to establish themselves and flourish. Some time after settling on the island in the middle of the river he renamed Manambondro, Andriamaroary returned to the north, to the river whose water he had drawn in a gourd, and there he is said to have been buried. And on the death of his daughter she too returned to the "origin" and "root" of her father's "ancestral water" for burial. Not until the deaths of her sons did Temanambondro begin to bury their dead at the mouth of the Manambondro River. Only then had they become rooted in place; only then were they truly zana tany, "children of the land".

Images of "roots" are not only one of the ways in which Temanambondro imagine connectedness to the place they dwell in, for "roots" also embody other important ideas, such as the growth and proliferation of people rooted in places, and the ability of people to move by "cutting" the "roots" that connect them to one place and transplanting them to another. For Temanambondro, being rooted in place is therefore a dynamic and regenerative process, and in images of "roots" we find a poetic elaboration through the trope of metaphor on some fundamentally important aspects of their experience of being-in-the-world.

\section{References}

Astuti, Rita

1993 Food for pregnancy: procreation, marriage and images of gender among the Vezo of western Madagascar. Social Anthropology 1:277-290.

Beaujard, Philippe

1983a Les conceptions symboliques de la royauté et l'exercise du pouvoir dans les royaumes Tanala de l'Ikongo (XVIIIe-XIXe siècles). In F. RaisonJourde (ed.) Les souverains de Madagascar, pp.299-336. Paris: Karthala.

1983b Princes et paysans: les Tanala de l'Ikongo. Paris: L'Harmattan.

Bloch, Maurice

1986 From blessing to violence: history and ideology in the circumcision ritual of the Merina of Madagascar. Cambridge: Cambridge University Press.

1987 The ritual of the royal bath in Madagascar: the dissolution of death, birth and fertility into authority. In D. Cannadine and S. Price (eds) Rituals of royalty, pp.271-297. Cambridge: Cambridge University Press.

Casey, Edward S. 
1987 Remembering: a phenomenological study. Bloomington: Indiana University Press.

1993 Getting back into place: toward a renewed understanding of the place-world. Bloomington: Indiana University Press.

Chandon-Moet, B.

1972 Vohimasina, village Malgache: tradition et changement dans une société paysanne. Paris: Nouvelles Editions Latines.

Cotte, Paul Vincent

1947 Regardons vivre une tribu Malgache: les Betsimisaraka. Paris: La Nouvelle Edition.

Deschamps, Hubert

1936 Les Antaisaka: géographie humaine, coutumes et histoire d'une population Malgache. Antananarivo: Imprimerie Moderne de l'Emyrne.

Deschamps, Hubert and Suzanne Vianès

1959 Les Malgaches du Sud-Est. Paris: Presses Universitaires de France.

Elle, Bjorn

1905-6 Note sur les tribus de la province de Farafangana. Bulletin de l'Académie Malgache 4:116-123.

Errington, Shelly

1989 Meaning and power in a Southeast Asian realm. Princeton, NJ: Princeton University Press.

Feeley-Harnik, Gillian

1991a Finding memories in Madagascar. In S. Küchler and W. Melion (eds) Images of memory, pp.121-140. Washington, DC: Smithsonian Institution Press.

$1991 \mathrm{~b}$ A green estate: restoring independence in Madagascar. Washington, DC: Smithsonian Institution Press.

Fernandez, James W.

1982 Bwiti: an ethnography of the religious imagination in Africa. Princeton, NJ: Princeton University Press.

Fox, James J.

1980 Introduction. In J.J. Fox (ed.) The flow of life, pp.1-18. Cambridge, MA: Harvard University Press. 
1993 Comparative perspectives on Austronesian houses. In J.J. Fox (ed.) Inside Austronesian houses, pp.1-28. Canberra: Department of Anthropology, Research School of Pacific Studies, The Australian National University.

Huntington, Richard

1986 The transformation of the Bara rural economy. In C. Kottak et al. (eds) Madagascar: society and history, pp.299-319. Durham, NC: Carolina Academic Press.

Hurvitz, David J.

1986 The "Anjoaty" and embouchures in Madagascar. In C. Kottak et al. (eds) Madagascar: society and history, pp.107-120. Durham, NC: Carolina Academic Press.

Kus, Susan and Victor Raharijaona

1990 Domestic space and the tenacity of tradition among some Betsileo of Madagascar. In S. Kent (ed.) Domestic architecture and the use of space, pp.21-33. Cambridge: Cambridge University Press.

Linton, Ralph

1928 Culture areas in Madagascar. American Anthropologist 30:363-390.

1933 The Tanala, a hill tribe of Madagascar. Chicago: Field Museum of Natural History.

Middleton, Karen

1995 Tombs, umbilical cords and the syllable fo. In S. Evers and M. Spindler (eds) Cultures of Madagascar: ebb and flow of influences. Leiden: International Institute for Asian Studies, Working Paper Series 2.

Molet, Louis

1956 Le bain royal àMadagascar. Antananarivo: L'Imprimerie Luthérienne.

Nérine Botokeky, Eléonore

1983 Le fitampoha en royaume de Menabe: bains des reliques royales. In F. Raison-Jourde (ed.) Les souverains de Madagascar, pp.211-220. Paris: Karthala.

Rahatoka, Salomon

1984 Pensée religieuse et rituels betsimisaraka. In J-P. Domenichini et al. (eds) Ny razana tsy mba maty: cultures traditionelles Malgaches, pp.31-92. Antananarivo: Editions de la Librairie de Madagascar.

Rajohnson, Henri

1908 Etude sur les Antanosy et les Antandroy. Bulletin de l'Académie Malgache 6:177-196. 


\section{Relph, Edward}

1985 Geographical experiences and being-in-the-world: the phenomenological origins of geography. In D. Seamon and R. Mugerauer (eds) Dwelling, place and environment, pp.15-31. Dordrecht: Nijhoff.

\section{Rolland, Dominique}

1984 Les Antemoro de la Matitanana. In J-P. Domenichini et al. (eds) Ny razana tsy mba maty: cultures traditionelles Malgaches, pp.93-126. Antananarivo: Editions de la Librairie de Madagascar.

\section{Smith, Jonathan Z.}

1987 To take place: toward theory in ritual. Chicago: University of Chicago Press.

Thomas, Philip

1995 Of houses, hearths and granaries: some aspects of gender among the Temanambondro of southeast Madagascar. Indonesia Circle 67 (special issue):340-358.

1996 Place, person and ancestry among the Temanambondro of southeast Madagascar. PhD thesis, University of London.

n.d.a. Burying and remembering: Temanambondro rites for the dead. Unpublished MS.

\section{Notes}

1 Fieldwork in the Manambondro region of southeast Madagascar was conducted between December 1991 and October 1993. The research was funded by the Economic and Social Research Council (UK), and carried out under the auspices of the Musée d'Art et d'Archéologie/Institut de Civilisations of the University of Madagascar in collaboration with the Ministère des Affaires Etrangères and the Ministère de l'Enseignement Supérieur of the Republic of Madagascar. My thanks to all these institutions for enabling me to carry out my work. A previous version of this paper was given at the London School of Economics in 1994, and I am grateful for the comments I received on that occasion, as well as to those people who, in various ways, have helped me shape the present form of the argument: Maurice Bloch, Cecilia Busby, Jennifer Cole, Gillian Feeley-Harnik, Jim Fox, Eric Hirsch and Roxana Waterson. Above all, however, my thanks go to my Temanambondro hosts, and in particular to those people who helped me find what I was looking for, and whose words are scattered throughout this paper: Kadia, Rabery, Tony and Mandiñ, as well as Nary and Nenety. Needless to say, I take responsibility for what lack of vision the paper currently displays.

2 I have chosen to refer to the named "kinds" (karazana) into which Temanambondro divide themselves as Ancestries with a capital so as to distinguish the term from its more general usage. For a more detailed discussion of Ancestries, house-groups, marriage and relatedness, see Thomas (1996).

3 This is an abbreviated version of the story of Andriamaroary but would be recognizable to those Temanambondro who know it in its more expanded form as a rendition of the main points. For other versions of the story, see Deschamps (1936:160-161) and Elle (1905-6:121-122); Elle, however, mistakenly attributes it to the Tevato, neighbours of the Temanambondro. For similar stories from the region involving what Linton referred to as the "baptism" of rivers, see Elle (1905-6:117, 121), Huntington (1986:301) and Beaujard (1983b:46-47, 76).

4 Mitadidy aminao ranon-draza ty. Hañary ñe foitrin'i $R$. Ndre niañavaratra. Ndre niañatsimo. Ndre niañkandrefana. Ndre de hotaman-tany añy de anao Rano e Manambondro ty avao tsy hohadiñony. 
5 The careful disposing (itself an act of placing) of placentae and umbilical cords is widespread throughout Madagascar, as is the idea that placentae are "siblings" of the newborn child: for the southeast, see Linton (1933:283-285), Deschamps (1936:134), Deschamps and Vianès (1959:56, 59, 88), Chandon-Moet (1972:102) and Beaujard (1983b:499). Whilst similar ideas and practices are widespread throughout Southeast Asia, given disputes over the Austronesian-ness of the Malagasy, it is noteworthy that they can also be found in parts of Africa: see, for example, Fernandez $(1982: 86,447)$ on the Bantu-speaking Fang.

6 The parallels between the corpse on the one hand and the standing-stone and teza on the other are several but cannot be gone into here. Neither can the significance of the images carved on the teza, one of a river-dwelling animal, the crocodile; and the second, a vessel for carrying water, the gourd. To some extent this outline of funerary rites refers to what Temanambondro see as a more traditional form of ritual practice. During fieldwork not all funerals strictly followed this pattern: for example, some commemorative monuments are now placed closer to the village, and standing-stones are occasionally made of concrete. A more comprehensive discussion of Temanambondro funerals is currently in progress (Thomas n.d.a.).

7 These terms of spatial reference are derived from the domestic space of houses: see Thomas (1995)

8 Note that in Malagasy the phoneme /u/ is written as an "o"; thus fo is pronounced "foo", as in "fool". In Malagasy the word fo means "heart", and comparative ethnography reveals a number of terms containing the syllable fo which display a recognizable thematic unity. Among Hazohandatse, children's umbilical cords (foetse) are taken and buried in a place which is referred to as the "root of our ancestors", fotorañ 'razan'ay (Middleton 1995); Vezo men are said to be the "source" or "origin" of pregnancy, fotoran'ateraha (Astuti 1993:281); Bemihisatra royal ancestors are referred to as the "fertile roots or genitals" (fototra) of the tree-person that is the royal tomb and which grows around them (Feeley-Harnik 1991a:136); and Betsileo use fototra to refer to the "foundations" of tombs and houses (Kus and Raharijaona 1990:29). In the Temanambondro dialect, fototra can be used to refer to the "origin" of something in time and/or space, such as the starting point of a journey, or the subject of a conversation; it is also used to mean the etymological root of a word (foto'teny). However, unlike fotora (which is used to refer to the trunks of trees), fototra is not used to refer to the roots of plants; here the word is vahatra. 



\section{Chapter 3. Remembering Origins: Ancestors And Places In The Gumai Society Of South Sumatra ${ }^{1}$}

\section{Minako Sakai}

\section{Introduction}

The notion of "origin" is a key concept for comparative studies of the Austronesians. ${ }^{2}$ Two ways of tracing origins have been observed among the Austronesians. One is represented by a genealogy or succession of personal names, demonstrated by various societies in eastern Indonesia. The other is what Fox (this volume) calls "topogeny", which consists of a succession of place names related to the journeys of their ancestors. ${ }^{3}$

This paper aims to illustrate a notable variation on Austronesian origin concerns through an analysis of Gumai ideas about origins. These people trace their origins through a succession of ancestral names. This succession is linked to recognized places of origin. A hierarchy of Gumai origin points, which are identified according to the timing of their generation, is crucial for Gumai ritual practice. Gumai origin rituals, whose core consists of invocations of ancestral spirits, need to be performed by the authentic descendants who act as the Jurai Kebali'an and Jurai Tue (ritual specialists), at origin places represented by origin houses. It is this linkage between persons and places that constitutes the authenticity of Gumai origin rituals and ritual specialists.

In this paper, I will first outline Gumai society where my research was conducted. ${ }^{4}$ Secondly, I will present a brief account of Gumai origin narratives in order to explain the generation of origin points and the origin ritual places, which correspond to each origin point and validate the authority of Gumai ritual specialists. Thirdly, I will explicate various levels of Gumai origin rituals in order to highlight the significance of the association between ancestral spirits and places in Gumai ideas about origins. 

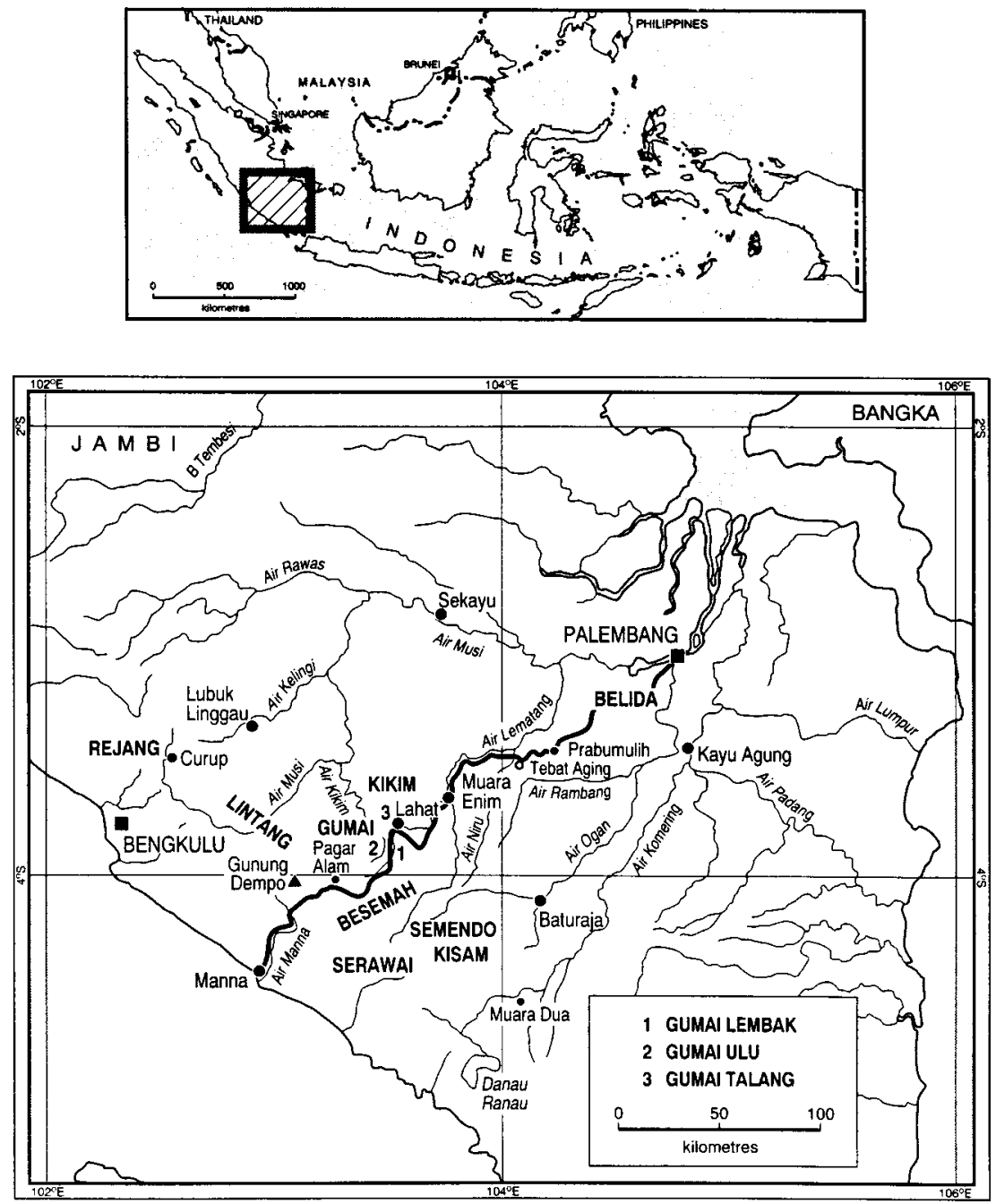

Map 1. Ethnic groups of South Sumatra

\section{The Ethnographic Setting}

The Gumai form one of the ethnic groups in the highlands of South Sumatra Province (Map 1). Their language belongs to one of the Malay dialects widely spoken in Southern Sumatran upstream societies. ${ }^{5}$ Their main villages are along rivers in Lahat and in Muara Enim districts (kabupaten). The data presented here came mostly from Gumai Talang, one of the three main Gumai settlements in Lahat district. ${ }^{6}$

The population of Gumai Talang in 1994 was estimated as 8,281 . The settlement consists of fourteen villages, the majority of them situated along the Trans-Sumatran Highway, along which big trucks and buses travel between 
North Sumatra and Java every day. ${ }^{7}$ Villages in Gumai Talang still maintain homogeneity in terms of their custom, tradition and religious practices. A few non-Gumai married to Gumai and living in their villages also observe Gumai customs such as marriage-related ceremonies and village ceremonies.

Table 1. Population in the settlement of Gumai Talang

\begin{tabular}{lcccc}
\hline Village name & Males & Females & Total & Households \\
\hline Tanjung Dalam & 199 & 253 & 452 & 84 \\
Suka Rame & 250 & 326 & 576 & 85 \\
Ngalam Baru & 400 & 450 & 850 & 95 \\
Mandi Angin & 364 & 372 & 736 & 147 \\
Tanjung Baru & 284 & 332 & 616 & 126 \\
Endikat Ilir & 226 & 312 & 538 & 116 \\
Darmo & 315 & 344 & 659 & 146 \\
Muara Tandi & 250 & 325 & 575 & 134 \\
Tanjung Karangan & 193 & 207 & 400 & 95 \\
Tanjung Periuk & 198 & 357 & 555 & 73 \\
Sugihwaras & 405 & 385 & 790 & 186 \\
Tanah Pilih & 375 & 415 & 790 & 120 \\
Batay & 220 & 195 & 415 & 98 \\
Tanjung Beringin & 172 & 157 & 329 & 76 \\
\hline
\end{tabular}

Source: Fieldwork.

Prior to Dutch colonization, the highlands of South Sumatra were linked to the port polities in the lowlands (Palembang) through the pepper trade. ${ }^{8}$ Yet upland societies, including that of Gumai, remained relatively independent from the rule of downstream societies, represented by the Sultanate of Palembang. ${ }^{9}$ However, when the Sultanate of Palembang fell under Dutch colonial rule in the early nineteenth century, the Dutch proceeded to conquer the highlands. The Gumai fought a war with them between 1856 and 1867, and finally compromised with them (Rustam-Effendi 1993:43-52).

During colonial times, the Gumai near Lahat were divided into three main residential groups which were designated as marga - Gumai Lembak, Gumai Ulu and Gumai Talang - and a pasirah was appointed as the head of each marga. ${ }^{10}$ This marga system remained in force until the Indonesian government implemented new administrative regulations in 1979. ${ }^{11}$ By the mid-1980s, the pasirah or marga system had been replaced by an autonomous village administration. Today each village is headed by a village headman (kepala desa), who is chosen every eight years and is under a camat (subdistrict head).

According to Gumai narratives, Islam penetrated South Sumatran upstream societies at the beginning of this century. Nowadays all the Gumai are formally Muslim and life-cycle rituals such as death, marriage and circumcision are performed according to Islamic rules. Nevertheless, Gumai perform ancestral rituals which still strongly regulate their social life. 
The Gumai consider that the world is divided into several spheres: the sky (aras), mountain/forest (gunung/utan), sea (laut) and earth (bumi); each of these is believed to be controlled by invisible supernatural spirits. Invisible supernaturals in each realm form a group headed by petunggu or junjungan and they are collectively called the four guardians (Empat Diwe). Junjungan di Aras are believed to possess control over life (nyawe), Junjungan di Gunung over security (penangai umat) and well-being, Junjungan di Laut over fortune (rezeki) and finally Junjungan di Bumi, represented by the Jurai Kebali'an, for communication between ancestors and their descendants.

Agriculture provides the main sources of livelihood for the Gumai. They produce coffee, rubber, fruits, coconut oil and dry rice using slash and burn cultivation. They utilize the forests for gathering useful tropical plants such as rattan and medicinal herbs and for clearing plots of land. They fear entering forests because the land in the forest is believed to be controlled by invisible spirits. $^{12}$

Failure to acknowledge the spirits' control over the land is considered to cause misfortune, such as accidents and sickness. Offended spirits will penalize those who have entered and destroyed their domiciles. ${ }^{13}$ To avoid offending the spirits, the process of clearing a portion of land to make a garden is accompanied by a series of rituals, whose purpose is to transfer the control of the land from the spirits to human beings. ${ }^{14}$ These rituals are intended to ask permission of the land spirits for the human beings to use a plot for their needs as tenants (numpang hidup). The interaction among spirits, ancestral spirits and human beings underpins everyday life in Gumai society.

In the following sections, I will outline the generation of various Gumai origin points and will illustrate Gumai concerns with "origin".

\section{The Generation of Origin Points}

Like the majority of groups in Indonesia, the Gumai concern with origin centres around ancestral spirits (arwah puyang). ${ }^{15}$ What is significant to the Gumai is, however, that their ancestral spirits are divided into several categories which constitute generation points. These are, from the beginning, Diwe (The Founding Ancestor), Ratu (below Diwe and before Puyang Ketunggalan), Puyang Ketunggalan (The Single Ancestor), Puyang Ketunggalan Dusun (The Single Village Ancestor) and Puyang Keluarge (Family Ancestors). The older the ancestral spirits are, the more influential they are considered to be. The features of these categories of ancestral spirits derive from the deeds and timing of each Gumai ancestor. To illustrate this, I will start with a brief account of these ancestors as recounted in Gumai oral narratives, many of which have features similar to the origin myth recounted in the Sejarah Melayu. ${ }^{16}$ 
The founding ancestor of the Gumai, Diwe Gumai (see Figure 1, no. 1), is believed to have descended to Earth from Negeri Aras, the country above the sky. He was watching the whole process of creation of the world and was reluctant to go down because the world looked dark. It was after he received the seventh order to descend that he finally jumped to Earth in a fruit one night before the full moon. ${ }^{17}$ He arrived at Bukit Seguntang, which was the only place in the world above the water at that time. ${ }^{18}$ Unfortunately, Diwe Gumai $(1)^{19}$ was trapped within the fruit and could not get out of it. He had to get assistance from Diwe Semidang (A), who descended to Earth the night after Diwe Gumai. Both of them used a spell to open the fruit and eventually Diwe Gumai came out. $^{20}$ After this event, Diwe Semidang went to Pelang Kenidai, at the foot of Mt Dempo, near Pagaralam in South Sumatra Province and settled there. ${ }^{21}$ Due to his position as the apical founding ancestor of the Gumai, Diwe Gumai is referred to as Diwe, which differentiates him from other Gumai ancestral spirits. His position constitutes the ultimate origin point for the Gumai.

Diwe Gumai married a princess from Bangka Hulu (Bengkulu) and was blessed with two sons, Ratu Iskandar Alam (3) and Ratu Selebar Alam (4). Ratu Selebar Alam is believed to have left Bukit Seguntang and to have gone to Pagarruyung in West Sumatra. ${ }^{22}$ He had two daughters. One of them, Putri Kumbang Mibar (7) married Junjungan di Gunung whose name was Ngawa Ratu Diwe Nyawe or Tuan Raje Nyawe. The other daughter, Putri Kumbang Nadar (9) married Junjungan di Aras called Tuan Meraje Sakti or Mentare Sakti. ${ }^{23}$ 


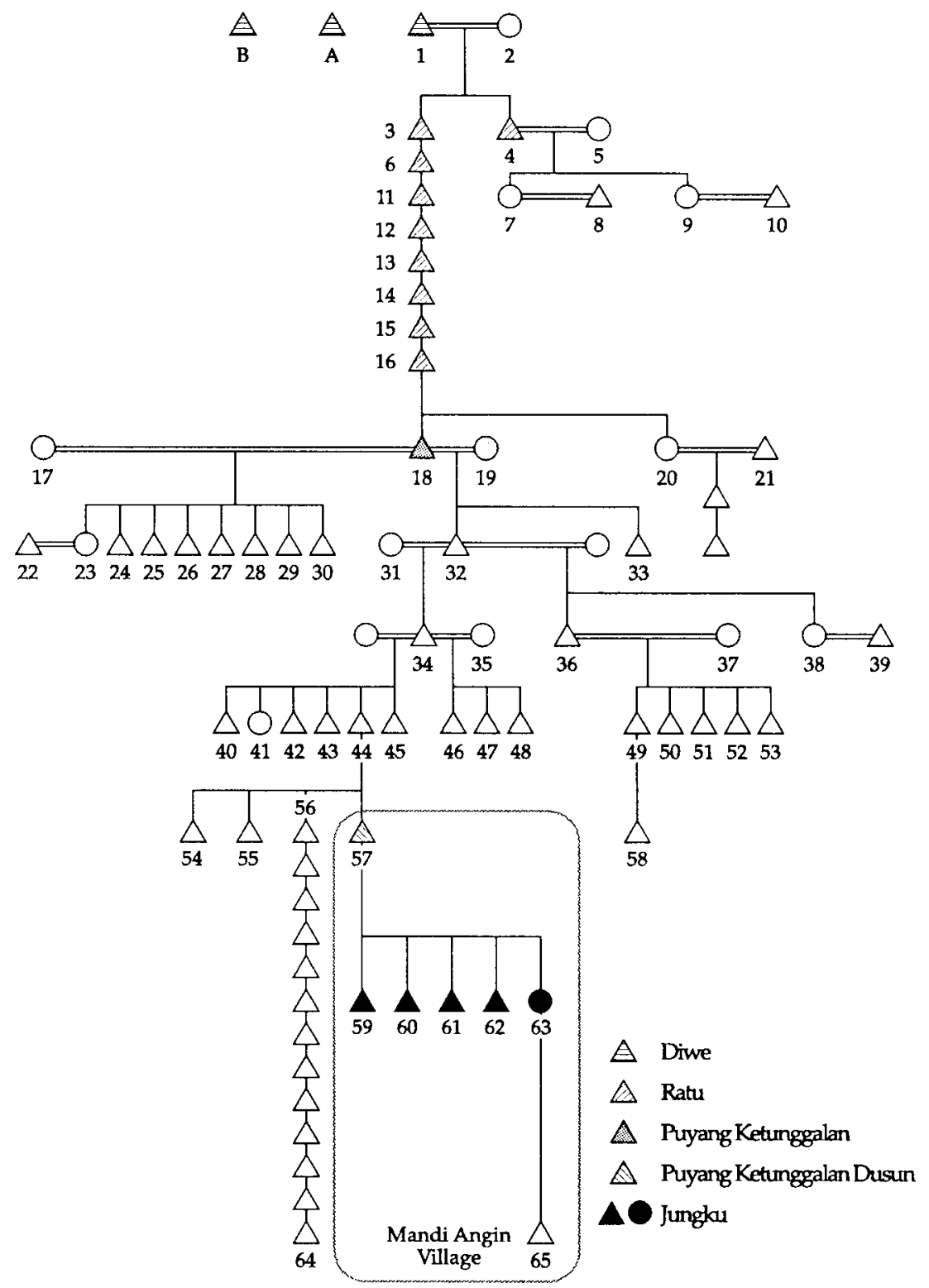

Figure 1. Genealogies of Jurai Kebali'an and of Mandi Angin village

Diwe Gumai possessed the title Jurai Kebali'an which has been passed on to descending male generations. The Jurai Kebali'an is the ritual specialist who acts to represent the whole Gumai offspring and to communicate with their ancestors. Before the demise of Diwe Gumai, his son, Ratu Iskandar Alam, became the second Jurai Kebali'an. Diwe Gumai left him all his heirlooms, which included a spell to call upon him in the sky. This spell, uttered every time the Jurai 
Kebali'an performs origin rituals, must not be made known to anyone except the Jurai Kebali'an.

Now let me explain the features of Ratu. The second Jurai Kebali'an remained at Bukit Seguntang, and in due course his place was taken by his son, Ratu Jemenang Sakti. Figure 1 shows the lineal succession of male descendants from the third to the ninth Jurai Kebali'an and that all their names include the title Ratu (see 6, 11, 12, 13, 14, 15, 16, Figure 1). The last Ratu (16) set up the first village in Kute Bantare in Rambang, where the Gumai started cultivating dry rice and hunting. He had a son and a daughter, Puyang Raden Simbang Gumai (18) and Putri Renik Dabung (20). ${ }^{24}$ Putri Renik Dabung married Junjungan di Laut, Ratu Siak Nage, who was half a crocodile (21). ${ }^{25}$

The title held by Puyang Raden Simbang Gumai (18), Puyang Ketunggalan, represents another crucial Gumai origin point to be remembered. He was the first ancestor referred to as puyang. This title emphasizes his special position in Gumai genealogy. He was the first to have ten children - nine sons and one daughter (23-30, 32-33). They went to new lands to set up new villages, which eventually led to the spread of Gumai descendants over South Sumatra. The Gumai state that each son followed one of the Nine Big Rivers that flow across South Sumatra to establish a new village. ${ }^{26}$ Today all the Gumai descendants claim that they originate from an ancestor who can trace his/her origin to one of the children of Puyang Raden Simbang Gumai.

The next important origin point for the Gumai to know about is Puyang Ketunggalan Dusun. Each apical ancestor of the Gumai who established a new village is called Puyang Ketunggalan Dusun (the Single Village Ancestor) or Petunggu Dusun (Guardian of the Village) and is buried in the graveyard within the original village. ${ }^{27}$ In the case of Mandi Angin village of Gumai Talang, Puyang Ketunggalan Dusun is represented by no. 57. These Gumai village founders have putative genealogical relations with the Jurai Kebali'an. Gumai villages still today consist of people who are affinally or lineally related to this founding ancestor. For the majority of the Gumai, the Puyang Ketunggalan Dusun constitutes their origin point at their village level.

Jungku or sungut is an origin point of a subgroup within a village. In the case of Mandi Angin village, they are represented by nos 59-63. It is through a jungku that the title of Jurai Tue, the caretaker of Gumai adat or custom, is transmitted. This position has been inherited from the first jungku founder, who was the child of the founding ancestor and was trusted to act as the caretaker of the village. ${ }^{28}$ A Gumai village consists of several jungku, one of which is responsible for choosing someone for the role of the Jurai Tue (65). The persons chosen are requested to live on their ancestral land and to have offspring. 
The authority and the realm of the Jurai Tue derive from his genealogical connections to the Puyang Ketunggalan and his association with the ancestral village. The authority to act as the Jurai Tue is limited to his village; he cannot act as the Jurai Tue for other Gumai villages. ${ }^{29}$

The lowest Gumai origin point is Puyang Keluarge (Family Ancestors). The Gumai refer to ascending generations above great-grandparents as puyang. These generations are called puyang even when they are still alive. Puyang Keluarge generally refers to ancestral spirits traced from their residential village and going back approximately four generations.

The process of generation of Gumai origin points highlights the nature of ritual specialists who perform corresponding origin rituals. It has also articulated features of Diwe, Ratu, Puyang Ketunggalan and Puyang Keluarge and the hierarchy of ancestral spirits. During the period from the Diwe to the Ratu, the principle was sequential lineal succession of the Jurai Kebali'an. All the Ratu are believed to have returned to the negeri atas angin at the time of their death. All of the Ratu daughters denote the supernatural as they married guardians of the spheres of the world. Puyang is an ancestor associated with a particular origin place (village). In the next section, I will present general features of interaction between ancestors and their descendants in order to investigate the affiliations between ancestral spirits and places.

\section{Genealogical Idioms by Which Relationships to Places are Expressed}

The Gumai believe that ancestors will assist in fulfilling the wishes made by their descendants. Wishes can be made at any place, but it is not uncommon for the Gumai to make a vow at the grave. Visits to tombs are called beziarah or the Gumai simply say "we will go to ancestors" (kami nak ke puyang). By burning incense made from benzoin (menyan) at a tomb, they speak to their ancestor/s to report on the expansion of the family. New members (mostly in-laws and new babies) are usually introduced to the ancestors. If they are in difficulties, this visit (ziarah) provides an opportunity to ask for the ancestor's help. They say, "if you help me and my wish comes true, I will come again, bring my family, slaughter a goat here and hold a big gathering" (sedekah). This is called making a vow or pledge (memasang niat). They promise that they will present sacrificial animals if their ancestors assist in fulfilling their wishes. Goats, chickens and water buffaloes are frequently slaughtered. ${ }^{30}$ Fulfilling a promise to their ancestors is called mbayar nazar, or mbayar sangi (paying off a promise).

Forgetting one's "origin" is believed to bring about all kinds of misfortune. When the Gumai have a traffic accident, suffer from any kind of disease, fire or death, they will search for a cause, and it is often ascribed to the family who did not "remember their origin". This is referred to as keselunagan, kesalahan or 
kuwalatan, which means punishment by ancestors for misbehaviour towards them. Even unfulfilled promises made by a deceased member of the family can cause misfortune to their descendants, such as a succession of accidents, sickness and infertility. Thus the Gumai believe that benevolent ancestors will become malevolent if not remembered properly.

The Gumai concerns with origins are also represented by places associated with their ancestors. it is a Gumai obligation (wajib) to remember his/her origin. Remembering origin (ngingat asal) is not just keeping a record of one's genealogy. One must also take certain actions such as visiting one's origin place and holding a gathering there. The gathering, sedekah, is performed at the house of relatives who occupy the place of their forebears and who receive their relatives when they return to their origin place.

Therefore an ancestral place, especially an ancestral village, holds significant value for the Gumai. The right to live in a village derives from Gumai genealogical affiliation with the ancestral village. It is prohibited to live in a village where one can trace no relations either lineally or affinally. ${ }^{31}$ Because of this exclusive residential rule, it is not uncommon to relocate a village site so that all the villagers can move to a new village for easier access to the main road. In order to maintain their affiliation with the ancestral place, the Jurai Tue brings a handful of soil and the trunk of an areca nut tree (pinang), both of which are planted in the centre of the new village.

The Gumai express a strong affiliation with their place of birth and residence as their "origin place". The village where a person was born and raised is considered to be his/her origin place (asal). ${ }^{32}$ Affiliation with asal also plays an important role at the time of death. The Gumai all expect to be buried in their ancestral graveyard. Despite Islamic teaching and the costs of transferring a dead body, it is not unusual to transfer the body of someone who has died in Jakarta all the way back to their own village for burial. Even after many years of outmigration to other towns, the Gumai consider that the bodies should be returned to their ancestral villages. ${ }^{33}$

The next section elaborates on how this affiliation between ancestors and places underpins each of the Gumai origin rituals practised at various origin points.

\section{Origin Rituals, Ritual Specialists and Ritual Places}

The Gumai do not have social strata. The only demarcation made is by succession to the roles of ritual specialists for Gumai custom and tradition, the Jurai Kebali'an and the Jurai Tue. ${ }^{34}$ Gumai ritual specialists do not traditionally have inherent secular power. 


\section{Origin Rituals, Ritual Specialists and Ritual Places}

The Gumai origin ritual for the whole society is called Sedekah Malam Empatbelas. It takes place every month on the thirteenth night according to the lunar calendar, which is when the Gumai believe Diwe Gumai descended to earth. It is held at the house of the Jurai Kebali'an (64), who is the twenty-sixth successor from Diwe Gumai and resides in Endikat Ilir village of Gumai Talang. The participants in this ritual are Gumai descendants in the southern part of Sumatra. Participants come to this ritual in order to make wishes, to pay off their promises and to ask for medicine, such as ointment. The ritual starts in the morning with the slaughter of participants' sacrificial animals for repaying promises, followed by the cooking of dishes and the organization of elaborate offerings. ${ }^{35}$ It proceeds to rituals involving invocations of ancestors at night. ${ }^{36}$ During my fieldwork period, Sedekah Malam Empatbelas consistently attracted about 250 people each month. ${ }^{37}$

Sedekah Malam Empatbelas consists of two parts, Sedekah Khusus and Sedekah Umum, both of which centre around invocations of ancestral spirits by the Jurai Kebali'an. The Sedekah Khusus is a ritual in which the ancestral spirits of Jurai Kebali'an's direct line are invoked. By burning incense and uttering spells, the Jurai Kebali'an starts invoking the spirits of his deceased father and proceeds up to Diwe Gumai to ask for the welfare of the Gumai descendants.

The Sedekah Umum is a ritual in which all the ancestral spirits of the participants are invoked. The Jurai Kebali'an reports the wishes made by participants and the fulfilment of promises to Gumai ancestral spirits. The highest spirit invoked in this ritual is Puyang Ketunggalan (18) since he is the unitary point and source of the expansion of all the Gumai descendants.

The Jurai Kebali'an is the ritual specialist for the whole Gumai community. ${ }^{38}$ In addition to performing the Sedekah Malam Empatbelas, he performs rituals at the time of crisis and calamity. ${ }^{39}$ The position of the Jurai Kebali'an is reckoned though this male line. Neither birth order nor seniority determines who will inherit the position. ${ }^{40}$ Personality and responsibility qualify a person to be successor. ${ }^{41}$

The words Jurai Kebali'an consists of two parts. Jurai is Gumai word for descendants. Kebali'an, derived from bali', means to return. Thus, the connotation is that the title signifies the place to which all the Gumai descendants should return. In line with this underlying meaning, the Jurai Kebali'an's house is open to all Gumai descendants. It is regarded as the origin house for all Gumai. It not only accommodates the Jurai Kebali'an's own family members, but also all other Gumai descendants. Every day someone comes to his house for consultation, and no less than ten people may be staying there. ${ }^{42}$ 
The Jurai Kebali'an's source of authority and his prerogatives over Gumai adat derive not only from his position as an heir, but also from his location at the origin house. As long as he is within the house of the Jurai Kebali'an, he can function as the Jurai Kebali'an. The Gumai say that "the Jurai Kebali'an does not go anywhere, he always stays home" (Jurai Kebali'an dide pegi ke mane mane, tetap di humah). This "house" (humah) consists of a house and a garden. When the Jurai Kebali'an is away from this compound, for instance at his second wife's house, he becomes a regular individual and is not able to play a role as the Jurai Kebali'an, His second wife's house is not regarded as the origin house for the Gumai. Thus, it is not appropriate for him to deal with Gumai adat issues when out of the Jurai Kebali'an's house. The Jurai Tue reporting to the Jurai Kebali'an about adat issues should go to the Jurai Kebali'an's house. If he is absent, it is legitimate to report to Jurai Kebali'an's wife or her children.

Inside his house, access to Jurai Kebali'an's bedroom is strictly restricted at all times; even his wives cannot sleep there. This is because the Jurai Kebali'an invokes his ancestral spirits at the time of Sedekah Malam Empatbelas inside this bedroom. Heirlooms are kept on a high platform in this room. It is therefore regarded as the special place for the Jurai Kebali'an to undertake the Sedekah Malam Empatbelas and to sleep in. ${ }^{43}$ Sedekah Malam Empatbelas cannot be performed at any other place but the house of the Jurai Kebali'an.

His genealogy as the Jurai Kebali'an, which directly serves to connect his origin with the founding ancestors, his knowledge about spells to invoke ancestral spirits at Sedekah Malam Empatbelas and his location at the origin house, constitute the authenticity of the Jurai Kebali'an. It is significant that the Jurai Kebali'an's ancestral spirits must be invoked at the house of the Jurai Kebali'an and be performed by himself. Thus, this invocation does not represent a mere genealogy, but also a succession of ancestral names attached to this Gumai origin place.

\section{Origin Rituals and the Ritual Specialist for a Village}

The origin ritual for a village is called Sedekah Pedusun, Sedekah Peliare Dusun or Sedekah Petunggu Dusun. It is meant for the village guardians and Puyang Ketunggalan Dusun, and traditionally took place in relation to Gumai agriculture. The first sedekah took place prior to clearing a piece of land, the second three months after rice planting and the third after the harvest of new rice. At present, the ritual is held once or twice a year in the house of the Jurai Tue. ${ }^{44}$ The rituals are attended by male members within the village who are household heads. A set of offerings is prepared by the wife of the Jurai Tue. The core of this ritual comprises an invocation of the Jurai Tue's "genealogy" in order to ask for the well-being of the villagers, including a good harvest. The Jurai Tue recites a succession of ancestral names starting from his deceased parents upward to the 
village founder. By doing so, all the spirits of forebears derived from the village founder can be called upon. After their invocation, the participants enjoy a feast.

The duty of the Jurai Tue is to act as the caretaker of Gumai adat. ${ }^{45}$ The title of the Jurai Tue can be transmitted to either a male or a female, but the role has to be enacted by a male member. If a woman is appointed to the office, her husband is supposed to carry out the duties as the Jurai Tue in that village. The genealogical affiliation of this husband with the founding ancestor does not create a problem. As long as he is married to the woman with the title of Jurai Tue and lives with her, he is expected to function as the Jurai Tue. If she dies or divorces him, he is no longer able to carry out duties of Jurai Tue. In general, the Jurai Tue is expected to have a spouse, and a widowed person, male or female, is not eligible. In practical terms, the wife of the Jurai Tue has to prepare offerings every time there is a sedekah, while he slaughters sacrificial animals and performs the core of the sedekah by invoking the ancestral spirits.

What is special about the Jurai Tue is the depth of their knowledge about their genealogies. While non-ritual specialists' knowledge of genealogies does not exceed four generations, it is the responsibility of the Jurai Tue to trace his genealogy to the founding village ancestors, the origin-point in the village (Puyang Ketunggalan Dusun). The genealogy of this village origin point has putative genealogical connections with the Jurai Kebali'an.

As is evident from the way in which succession to the title of the Jurai Tue takes place, the genealogies of the Jurai Tue are neither patrilineal nor matrilineal: they are a succession of ancestral names traced through residential locality. The spirits of ancestors who had married a person with the title of Jurai Tue are also invoked in origin rituals practised by the Jurai Tue. The underlying logic is the genealogical connection which is associated with his/her origin place. This way of tracing social origin is also practised by the Gumai when they cite male and female names in a succession when talking about their pedigree.

Origin rituals of a family need to take place at the family's origin place. In order to maintain affiliation with the ancestral village, one child is always encouraged to stay at his or her parent's place. This rule is called nuduko'ka jurai, or menunggu dusun. He or she, once officially announced, normally inherits the house of origin and agricultural fields, and is obliged to produce offspring in the natal place. This is called tunggu tubang. There is no special preference for men or women for tunggu tubang among the Gumai. His/her house should accommodate relatives when they wish to return to their birth place and is used for the venue of a sedekah. The house and the owner of the house are regarded as the representation of the ancestors in their village. The heir cannot make the decision to sell this house by him/herself. The decision should be made through discussion with his/her siblings. In principle, the house cannot be sold to anyone who does not have traceable genealogical connections with the village. 
The Gumai are encouraged to return to their origin place once in a while to perform a sedekah. If this presents the individual/s involved with problems due to the expense of the ritual, the Gumai are encouraged to perform tandang sedekah. Tandang means to sleep in someone's house, but in this context it means to hold a sedekah at someone's house. When those who have not been to their ancestral village for a long time eventually return to their village to attend a sedekah (such as marriage ceremony or circumcision) organized by someone else, they often contribute sacrificial animals to the family holding the sedekah in order to prove their connections with this village. Their intention is to show that they have not forgotten their ancestral village and their contribution of sacrificial animals is proudly announced in public at the sedekah.

To end this section, I will present a case which will exemplify Gumai concerns with origins which are represented by persons and places. In this case, a family who had lost contact with their origin created a new "authentic" origin place and performed a sedekah.

\section{Case}

Dewi (a pseudonym), a woman from Lintang, was married to Arpan (a pseudonym), and lived in a village in the subdistrict of Ulu Musi in the Lahat district. Dewi's husband's great-grandfather was said to be from Gumai Talang, but Arpan himself had never been to his great-grandfather's village, nor did he know exactly to which village his great-grandfather belonged. Dewi's sudden sickness began after they had lost three grandchildren. One day she felt as if someone was stabbing her lower back with a knife. Dewi's husband called a local healer (dukun) and he pointed out that Ade kesalahan di sebelah laki ("There has been a wrong to ancestors on the husband's side"). Dewi became unconscious and possessed, and said, "Yes, I admit that our family originated from Gumai. If I become healthy again, I will bring a goat there. The medicine will be available one kilometre away from this home". The family searched and came to a hut in the field (pondok). They found a piece of benzoin. ${ }^{46}$ So they burnt it to confirm their promise that they would visit the origin village of their great-grandfather.

However, they did not know any relatives who could be genealogically traced in Gumai Talang. They only knew Mim, a son of Soleh who lived in Muara Tandi of Gumai Talang, because Mim was the best friend of Yaman, a grandchild of Arpan's brother. The friendship between Mim and Yaman was so intense that they even developed adopted "brother" relations. ${ }^{47}$ Therefore, it was decided that the sedekah would take place at Soleh/Mim's house. The family of Arpan chartered a mini-bus and travelled with sacrificial animals over $130 \mathrm{~km}$ in order to undertake a sedekah in their ancestral land. 
This case demonstrates that the venue of the sedekah for origin rituals can be created through "adopted" genealogical ties to ancestral land. The affiliation through personal ties and ancestral land is crucial for the Gumai origin concerns.

\section{Conclusion}

The Gumai way of tracing their social origin is represented by a succession of ancestral names connected to the origin places. These places form a hierarchy of Gumai origin points which are connected with origin rituals by specialists for each origin point.

Several origin cults are performed because the Gumai recognize various origin points, each represented by ancestors affiliated with specific places. Each of these origin points has to be remembered by the respective ritual and ritualist. What is central to the Gumai are the associations of "person" and "place" which underpin the Gumai concerns with origins. To maintain associations, rituals depending on origin points are undertaken at the corresponding origin place.

Failure to maintain ties is believed to infuriate the ancestral spirits and will cause misfortune among their descendants.

The authority of the Gumai origin ritual specialists derives from their genealogies traced through an origin point. It is therefore their genealogical connections with their ancestors and their association with origin places that enable Gumai ritual specialists to perform origin rituals and to convey the wishes of Gumai descendants on their behalf. Remembering "origin" means to return to an origin point, both genealogical and spatial.

\section{References}

Andaya, Barbara Watson

1989 The cloth trade in Jambi and Palembang society during the seventeenth and eighteenth centuries. Indonesia 48:27-47.

1993 To live as brothers: southeast Sumatra in the seventeenth and eighteenth centuries. Honolulu: University of Hawaii Press.

Brown, C.C.

1970 Sejarah Melayu or Malay annals. An annotated translation by C.C. Brown, with a new introduction by R. Roolvink. Kuala Lumpur: Oxford University Press.

Collins, William

1979 Besemah concepts: a study of the culture of a people of South Sumatra. PhD thesis, University of California, Berkeley.

Connor, Linda, Patsy Asch and Timothy Asch 
1986 Jero Tapakan, Balinese healer: an ethnographic film monograph. Cambridge and New York: Cambridge University Press.

de Josselin de Jong, P.E.

1964 The character of the Malay Annals. In J. Bastin and R. Roolvink (eds) Malayan and Indonesian studies: essays presented to Sir Richard Winstedt on his eighty-fifth birthday, pp.235-241. Oxford: Clarendon Press.

Drakard, Jane

1990 A Malay frontier: unity and duality in a Sumatran kingdom. Ithaca: Southeast Asia Program, Cornell University Press.

Dobbin, Christine

1975 The exercise of authority in Minangkabau in the late eighteenth century. In A. Reid and L. Castles (eds) Pre-colonial state systems in Southeast Asia: the Malay Peninsula, Sumatra, Bali-Lombok, South Celebes. Monographs of the Malaysian Branch of the Royal Asiatic Society No. 6. Kuala Lumpur: The Malaysian Branch of The Royal Asiatic Society.

Foley, W.A.

1981 Sumatra. In S.A. Wurm and Shiro Hattori (eds) Language atlas of the Pacific area. Canberra: The Australian Academy of the Humanities in collaboration with the Japan Academy.

Fox, J.J.

1995 Origin structures and systems of precedence in the comparative study of Austronesian societies. In Paul Li, Cheng-hwa Tsang, Ying-kuei Huang, Dah-an Ho and Chiu-yu Tseng (eds) Austronesian studies relating to Taiwan, Symposium series of the Institute of History and Philology, Academia Sinica, 3, pp.27-57. Taipei, Taiwan, ROC: Academia Sinica.

1996 Introduction. In J.J. Fox and C. Sather (eds) Origin, ancestry, and alliance: explorations in Austronesian ethnography, pp.1-17. Canberra: Department of Anthropology, Research School of Pacific and Asian Studies, The Australian National University.

Fox, J.J. (ed.)

1993 Inside Austronesian houses: perspectives on domestic designs for living. Canberra: Department of Anthropology, Research School of Pacific Studies, The Australian National University.

Galizia, M.

1995 Aufstieg und Fall der Pasirah: Zentralstaatliche Vereinnahmung und lokale Machtstrategien. Berlin: Reimer. 
1996 Village institutions after the Law no. 5/1979 on village administration. The Case of Rejang-Lebong in South-Western Sumatra. Archipel 51:135160 .

Hollan, Douglas

1989 The personal use of dream belief in the Traja Highlands. Ethnos 17(2):166186.

Hirosue, Masashi

1993 Port of trade polities and hinterlands in North Sumatra. Southeast Asia: History and Culture 22:3-35.

Jensen, Erik

1974 The Iban and their religion. Oxford: Clarendon Press.

Kathirithamby-Wells, J.

1993 Hulu-hilir unity and conflict: Malay statecraft in East Sumatra before the mid-nineteenth century. Archipel 45:77-96.

Lipinsky, E. and T. Kato

n.d. Land tenure and village administration: Sumatra regional planning study, Province [of] South Sumatra. Bonn: University of Bonn.

Mabuchi, Toichi

1974 Magico-religious land ownership in general Formosa and Southeast Asia. In Ethnology of the Southwestern Pacific: the Ryukyus-Taiwan Insular Southeast Asia. Taipei: The Chinese Association for Folklore.

Mitani, Yasuyuki

1980 Languages of South Sumatra. In Y. Tsubouchi, N. Iljas, Y. Takaya and A.R. Hanafiah (eds) South Sumatra man and agriculture. Kyoto: Center for Southeast Asian Studies, Kyoto University.

Moyer, David

1984 South Sumatra in the Indonesian field of anthropological study. In P.E. de Josselin de Jong (ed.) Unity in diversity: Indonesia as a field of anthropological study. Dordrecht-Holland/Providence: Foris Publications.

Rustam-Effendi

1993 Gumai perang melawan belanda. Lahat: Sumber Karya.

Steadly, Mary Margaret

1993 Hanging without a rope: narrative experience in colonial and postcolonial Karoland. Princeton: Princeton University Press.

Suzuki, Tsuneyuki 
1996 Palembang okokuni okeru nairiku shihai sedo. Tokyo Joshi Daigaku Shiron 49:1-21.

Teeuw, A.

1964 Hikayat raja-raja pasai and Sejarah Selayu. In J. Bastin and R. Roolvink (eds) Malayan and Indonesian studies: essays presented to Sir Richard Winstedt on his eighty-fifth birthday. Oxford: Clarendon Press.

\section{Tomizawa, Hisao}

1981 A structural analysis of the Sejarah Melayu: an essay on a Malay dynastic myth. Minzokugaku-Kenykyu: the Japanese Journal of Ethnology 46(1): 55-79.

\section{Voorhoeve, Petrus}

1955 Critical survey of studies on the languages of Sumatra. 's-Gravenhage: M. Nijhoff.

Waterson, Roxana

1990 The living house: an anthropology of architecture in South-East Asia. Oxford: Oxford University Press.

Weinstock, Joseph A.

1987 Kaharingan in southern Borneo. In R.S. Kipp and S. Rodgers (eds) Indonesian religions in transition. Tucson: The University of Arizona Press.

\section{Notes}

1 I wish to thank Professors Barbara Andaya, James J. Fox and Amran Halim; Drs Barbara Holloway, Ian Proudfoot and Kathy Robinson. I also wish to thank Professor Anthony Reid and Dr Amanda Scott for their reading of, and comments on, earlier versions of the draft. Discussions with Professor Fox have provided me with invaluable insights. I am deeply grateful to the Gumai in South Sumatra, especially the family of Bapak Rumsyah, the present Jurai Kebali'an, who kindly accepted and supported my research.

2 A problem arising from the notion of "descent" for comparative studies on Austronesian speakers has been raised. One of the key issues this paper reflects is explained in Fox (1995:33-34),

it is purportedly a matter of significance that many Austronesian societies have no "descent groups" and indeed, the very notion of "descent" appears somewhat questionable in regard to such societies. ...The use of the notion of descent may thus inhibit, rather than foster, efforts at comparison.

Whereas a concern with "descent" may be of variable interest or of complete indifference in Austronesian societies, a concern with "origins", variously defined, is a matter of the greatest concern.

${ }^{3}$ Place and place names constitute an important dimension of Austronesian origin concern. Fox (1996:5) states "recourse to notions of place is also critical in identifying persons and groups, and thus tracing origins". Many Austronesians identify houses specifically as their origin sites. For discussions of houses and origin sites, see Waterson (1990) and Fox (1993 and this volume).

4 My fieldwork on the Gumai in South Sumatra was undertaken over twenty months from May 1994 to March 1996. The research was undertaken under the auspices of LIPI, the Indonesian Institute of Sciences, and sponsored by Universitas Sriwijaya in Palembang. At various stages of this research, it was financially supported by research grants from the Daiwa Bank Foundation for Asia and Oceania and the Matsushita International Foundation, and a PhD scholarship from The Australian National University. I am grateful for their generous support. 
${ }^{5}$ Numerous local dialects, traditionally known as Middle Malay (Voorhoeve 1955) are spoken in various districts in the highlands. They are spoken by neighbouring ethnic groups such as Lematang, Rambang, Belida, Besemah, Semendo and Serawai. Professor Amran Halim states that there are four Malay variants recognizable in South Sumatra Province (personal communication). They are the $o, e$, stressed é, and au variants. The vowel at the end changes as follows: "mana" (where) in Bahasa Indonesia is realized as "mano", "mane", "mané" and "manau" respectively. Mitani (1980) states that local differences between the Malay dialects of South Sumatra are not great enough for further classifications yet he draws attention to a difference between Musi Malay and Highland Malay. For a map of Malay language distribution, details of Malay language in Sumatra, see Foley (1981) and Mitani (1980). The diversity and spread of variants of Malay dialects coincide with the geographical spread of the Gumai in Southern Sumatra. However, since as yet no full studies of Southern Sumatran dialects have been undertaken, the connection between Malay variants and Gumai territorial expansion processes cannot be tested. As the Besemah, a neighbouring ethnic group with different founding ancestors, outnumber the Gumai, the Gumai language is often called Bahasa Besemah by outsiders such as people in Palembang. The Gumai themselves refer to their language as Bahasa kite (our language) or Bahasa dusun (village language).

6 Two other Gumai settlements are Gumai Ulu and Gumai Lembak in Pulau Pinang subdistrict of Lahat District.

${ }^{7}$ Due to this easy access to transportation, the Gumai Talang villagers travel to Lahat, the district capital or even to Palembang, the capital city of South Sumatra Province, approximately $220 \mathrm{~km}$ away, for shopping and education.

8 For detailed historical studies of trade and upland and lowland relations in southeast Sumatra, see Andaya $(1989,1993)$. Trade also connected the interior peoples of northern and eastern parts of Sumatra to coastal port polities. For studies in North Sumatra, see Drakard (1990) and Hirosue (1993) and for an overview of East Sumatran cases, see Kathirithamby-Wells (1993).

9 Suzuki (1996:1-21) classifies this area under the rule of the Sultanate of Palembang into three administrative regions according to the nature of their obligations to the Sultanate as subjects. The Gumai area near Lahat belongs to Sindang, in which the border control and tribute were major obligations. 10 Lipinsky and Kato (n.d.) state that the pasirah system was originally a development in conjunction with the Palembang Sultanate. The pasirah was titled Depati. For a case study of a pasirah system in southwest Sumatra, see Galizia (1995).

11 This change derives from Undang-Undang Republik Indonesia No.5 Tahun 1979 tentang Pemerintahan Desa. For a study on the effect of implementation of this law in southwest Sumatra, see Galizia (1996).

12 The belief that the spirits are the primary owners of the land is widely shared among Austronesian speakers as well as non-Austronesians. For an Austronesian example, see Mabuchi (1974).

13 The sickness cannot be cured without carrying out a curing ritual called beruroh.

14 The same logic works prior to clearing a field or constructing the main pillars of a house.

15 Arwah is a Gumai term for soul/s of the deceased, which differ from guardian spirits of the spheres of the world. Puyang (ancestors) can be used to refer to generations above grandparents.

16 The Sejarah Melayu, commonly translated as the Malay Annals, is not a chronicle but "a story setting out the descent of Malay Rajas with their customary ceremonial" (Brown 1970:x). It recounts the descent of the first Malay kings who claimed to be offspring of Alexander the Great. For the nature of various Malay origin stories, see de Josselin de Jong (1964) and Teeuw (1964). Based on a structural analysis of the Malay origin stories, Tomizawa (1981:67-68) states that the integration of the three spheres (sky, earth and water) constitutes an important theme in Malay cosmology. The following Gumai origin myth cited in this paper illustrates this integration process.

17 This timing is still used for performing rituals called Sedekah Malam Empatbelas in which all the ancestral spirits are invoked by the Jurai Kebali'an.

18 Bukit Seguntang is a hill in Palembang which is believed to be the place where the first three kings descended from heaven according to the Sejarah Melayu (Brown 1970: 14). These three princes claimed to be descendants of Raja Iskandar Dzu'l Karnain (Alexander the Great) and they were met by two women there. Currently there exist several graves on Bukit Seguntang, the identities of which are not determined. Gumai informants told me during my fieldwork that several graves existed and two of them are believed by the Gumai to be the graves of the wife of Diwe Gumai and her son, Ratu Iskandar Alam. These graves are sometimes visited by the Gumai.

19 Bracketed single numbers and letters correspond to symbols in Figure 1.

20 To remember this incident, the Jurai Kebali'an is prohibited from eating this fruit, kundur. Based on their origin account, a Gumai ritual specialist, Jurai Tue, explained to me that the word Gumai may be 
divided into two parts, the first gum means "descended first", and mai means "just became visible, and real". In daily life these words are not in use. Collins (1979:24) collected this origin myth from a Besemah informant and mentioned that Diwe Gumai and Diwe Semidang disputed over who was actually the elder, but the Gumai ritual specialists I spoke to just emphasized that Diwe Gumai descended first and did not mention the dispute between Diwe Gumai and Diwe Semidang.

21 Atong Bungsu (B), another founding ancestor of the Besemah, descended on Bukit Seguntang after the world had become populated.

22 The Gumai claim that Gumai communities exist in Pagarruyung. Pagarruyung constitutes the heartland of the Minangkabau and the seat of the Raja Alam, who claimed to be a descendant of Alexander the Great, and one of the three Supra village Minangkabau chiefs was located there. For details, see Dobbin (1975).

23 The spirit of Putri Kumbang Mibar is considered to reside in Mt Dempo near Pagaralam. The spirit of Putri Kumbang Nadar is considered to live in the sky.

24 Puyang Raden Simbang Gumai is widely known as Puyang Suke Milung.

25 Putri Renik Dabung was kidnapped by Ratu Siak Nage and her brother, Raden Simbang Gumai, went underwater to look for his lost sister.

26 Batang Hari Semblian (Nine Big Rivers) implies the whole area of South Sumatra, since numerous rivers flow across the southern part of Sumatra.

27 Due to several village relocations, many Gumai villages do not have the tomb of this founding ancestor within the present village site. Some villages have a monument (tapak) to represent the founding ancestor's grave.

28 It should be noted that the jungku member who carries out the role of the Jurai Tue is not always the eldest child. The eldest jungku member is respected and is called tue jurai, which means "the eldest offspring".

29 Some Jurai Tue in Gumai Talang no longer reside in their own villages. One Jurai Tue resides in his wife's village within Gumai Talang, but he cannot act as the Jurai Tue for this village. He returns to his village where he is supposed to act as the Jurai Tue in order to perform origin rituals.

30 The colours of sacrificial animals, in particular those of chickens and goats, are crucial for performing their rituals. Choosing wrong-coloured animals makes the ritual invalid.

31 Previously, there were two types of marriage which prescribed residential patterns. Belaki was a marriage of patrilocal residency. Tambi anak berape duit was a marriage of uxorilocal residency. In both types, when the person who originally belonged to the village died, the classificatory sister/brother was supposed to re-marry the widowed partner to continue the marriage (nungkat). For a historical study of connubium principles in South Sumatra, see Moyer (1984).

32 In the case of a child's parents taking virilocal residence, a Gumai would tend to emphasize more affiliation with forebears among paternal kin. In cases of uxorilocality, a child would tend to find more affiliation with the mother's village of origin. If asked where he/she is from, the reply is determined by the place or village where he or she has spent most of his/her life.

33 The Gumai in towns, out of their origin villages, tend to have Gumai as a part of their name. In Gumai Talang, people do not include Gumai in their name.

34 I have not discussed the Mimbar in this essay. At present the Mimbar are not as significant or active as the Jurai Tue and the Jurai Kebali'an.

35 During my fieldwork, the average number of goats used for a sacrificial purpose each month was sixteen.

36 The first wife of the Jurai Kebali'an is responsible for receiving guests and arranging offerings. Guests also actively participate in cooking, dish washing and cleaning the house.

37 Since the majority of them are peasants, they have more free time after the rice harvest in the dry season (June, July). This timing coincides with school holidays in Indonesia, and during these two months, the number of participants reached about six to seven hundred (including children).

38 The term balian in Indonesia is frequently used to refer to a shaman/spirit medium. For an example from Bali see Connor, Asch and Asch (1986) and for an example from Kalimantan see Weinstock (1987). Yet Jurai Kebali'an is not a shaman who can be possessed by ancestral spirits, rather he is a priest who can mediate between ancestral spirits and their descendants.

39 The Jurai Kebali'an performs Sedekah Nimbang Beneh (the ritual of weighing of rice seeds), which is practised only when the Gumai have a succession of bad crops. A better crop is asked for through an 


\section{The Poetic Power of Place}

invocation of Gumai ancestral spirits by the Jurai Kebali'an. Sedekah Upat Diwe is a cleansing ritual for the family of the Jurai Kebali'an.

40 In the case of polygamy, the heir is chosen from sons born to the Jurai Kebali'an's first wife.

41 The person who is suitable to act as the Jurai Kebali'an should have an ability to talk to anyone and to think on behalf of others. He should not easily lose his temper. Being thoughtful and active in the community constitutes a key element.

42 People who are suffering from financial problems, and/or who cannot stay in their village for various reasons always stay at the Jurai Kebali'an's house. They help to clean the house, take care of the gardens, and receive free food during their stay. They say that the house of the Jurai Kebali'an is their origin house, and they believe that it is their own house. The Jurai Kebali'an's family cannot prevent anyone coming to stay, as they admit that guests also belong to this house.

43 Among the Gumai, dreaming of ancestors is interpreted as a message from their ancestors. Dreaming in various Malay-Indonesian contexts provides a way to receive ancestral messages and to encounter spirits. See Hollan (1989) for a case on the Traja of Sulawesi, Jensen (1974:116-120) on the Iban of Sarawak and Steadly (1993:158-161) for the Karo Batak of North Sumatra.

44 At present, the timing is chosen to coincide with two major Islamic festivals, Idul Fitri and Idul Adhah because this is when all the villagers return to their own village from their gardens for prayers.

45 If there has been a breach of sexual conduct in his village, the Jurai Tue needs to perform a cleansing ritual (Sedekah Besehka Dusun) to cleanse the village and to apologize for this misbehaviour to the ancestors. Without such a ritual, the state of impurity is believed to cause calamity such as sickness and attacks by tigers. The Gumai abhor naming tigers (harimau). When they have to refer to tigers, they quietly say, "puyang", meaning ancestor. Crocodiles (buaye) are also regarded as Gumai ancestors, and the Gumai should not kill them.

46 In order to communicate with ancestral spirits, benzoin (menyan) is usually burnt in Gumai ancestral rituals.

47 It is not unusual for the Gumai to have adopted family relations, such as parent-child and/or sibling relations. Sometimes the Gumai hold a sedekah to announce in public the establishment of these adopted kinship ties. Those adopted have no right to claim property; however, they maintain close social ties with their family. 


\section{Chapter 4. The Contested Landscapes of Myth and History in Tana Toraja}

\section{Roxana Waterson}

In the English language "landscape" is a word that comes, as Olvig (1993:308) reminds us, with many layers of "concealed, congealed meanings", but having a predominant association with the visual, specifically with the idea of topography as seen from a particular viewpoint; its original seventeenth century sense was of a painting of natural scenery, only subsequently of the vista itself, or of the landforms of a particular area. For anthropologists the effort to comprehend an unfamiliar way of life leads to a different kind of concern with landscape: an attempt to understand the involvement of people with the land that over time has generated a "sense of place" for them. ${ }^{1}$ This sense of place may be derived from many things. In hunter-gatherer societies, a powerful sense of place is commonly derived from interacting with the land, from living in it and off it, and bringing it alive through myth and ritual performance, without the need to effect alterations by means of architecture or construction. Other landscapes, even if perceived to be "natural", are in fact transformed and moulded by centuries of intensive human use and changing agricultural practice (Hoskins 1956). The visual perspective is thus only one among many possible dimensions by which a landscape can be known and comprehended. Moreover, as various authors note (for example, Bender's discussion of Stonehenge in Britain [1993]), meanings may not only be constantly revised over time, but may be contested, more or less fiercely, by those with different interests at any particular historical moment.

My own concern with questions of landscape and identity derives from my fieldwork among the Sa'dan Toraja of Sulawesi. ${ }^{2}$ The Toraja occupy the highlands of the province of South Sulawesi, in the kabupaten or sub-provincial district of Tana Toraja, whose population according to the census of 1990 is around 370,000. Many Toraja today also live outside of this region, having migrated to cities or to other parts of Indonesia in search of work or higher education. The majority of Toraja today are Christian. Most of them are members of Gereja Toraja, the Toraja Church, which is Calvinist, though there is also a minority of Catholics and adherents to a variety of more recently arrived sects including Seventh Day Adventists, Pentecostalists, Baptists and others. The indigenous religion, now known as Aluk to Dolo or "Way of the Ancestors", won official recognition from the Indonesian government in 1969, remaining one of the few indigenous religions to have done so. However, since that time the decline in its following has been rapid, only accelerating over the past decade. 
According to 1990 census figures, its adherents now constitute a mere ten per cent of the population; most of these are older people and those living in the remoter districts. Knowledge of myths of origin and details of oral history has never been evenly distributed, but interest in these matters has not entirely died away, because of their continued political significance in relation to claims of precedence in the present (Waterson 1992). It is these questions of precedence that I shall principally address in this paper. The interweaving of genealogy and place names, which are also the sites of origin houses (tongkonan), have a bearing on present-day claims to status. They provide one illustration of the themes of precedence and topogeny developed by Fox in this volume and elsewhere (Fox 1994, 1995).

\section{Houses, Myths and Genealogies in the Toraja Landscape}

The Toraja landscape is a mountainous one of great natural beauty. This landscape is imbued with meaning partly through the Aluk to Dolo, which, like most indigenous religions of small-scale societies, is characteristically animist and highly localized, being intimately linked with the context in which it has evolved. Aluk populates the natural world with deata - deities or nature spirits - and attributes to the ancestors, whose rock graves dot the landscape, a close familiar presence and a continued concern with the fertility of the land and of their living descendants who work it. Features of the landscape such as mountains and rivers have a place in myths and oral histories, especially the genealogies and accounts attached to particular noble origin-houses. Some of these myths tell of founding ancestral couples described as to manurun di langi' (ones who descended from the sky) and to kendek diomai liku (ones who rose out of a pool), of whom the man is said to have descended from the sky on to a mountain top, and married a woman who rose out of a river pool. These supernatural ancestors give prestige to the houses they founded, which in the past were the locus of political power, their occupants exercising control over local villages or groups of villages. The houses themselves were visibly magnificent, with their huge roofs and rich carving, contrasting with the simple bamboo houses built by commoners. Periodically they would serve even more dramatically as centres of power, whenever they became the sites for the enactment of elaborate rituals, which validated and reinforced the status of aristocratic families, while simultaneously becoming a part of the house's ongoing history. 


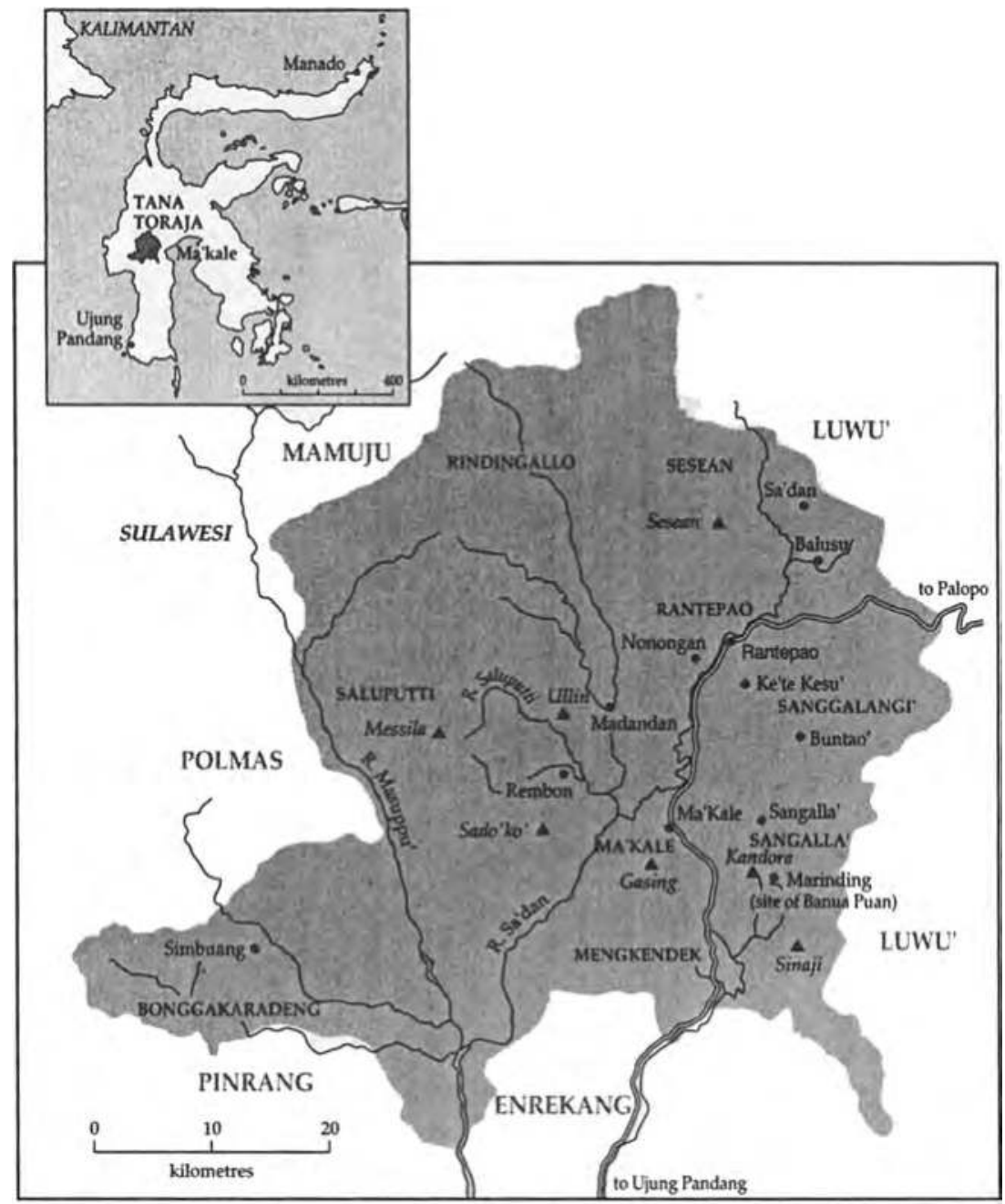

\section{Map of Tana Toraja}

In Tana Toraja, houses, genealogies, myths and histories are all closely bound up together and embedded in local landscapes. Houses are the major points of reference within the bilateral kinship system. People trace their descent equally from houses on both sides of the family, where their parents, grandparents, or more distant ancestors were born. At the birth of a child, the father buries the afterbirth on the east side of the house, so that over time, the house becomes the place where "many placentae are buried", and thus should never be moved. Some origin-houses associated with very important ancestors have in fact long ceased to exist, but their sites are still well remembered and in theory if the descendants willed it, they could be rebuilt. These houses have genealogies with a depth of between twenty and thirty generations, and many people in Toraja 
can ultimately trace descent back to them. When people recount such genealogies, they tell who married whom, who were their children, and where those children then moved to in order to found new "branch" houses of their own. Founding and branch houses are sometimes characterized as "mother" and "child" (indo'na/anakna); sometimes, in a botanical metaphor familiar from many other Indonesian societies, as "trunk" and "branch" (garonto'/tangke), or the original founding house may be termed ongi'na (ongi: stem, as in the stem of a fruit); when demonstrating this idea, one informant picked up a mangosteen, another a coconut, pointing out how "the whole fruit grows from the stem". ${ }^{3}$ The house sites form a sort of network, providing what is as much a geographical as a historical account of the settlement of the Toraja landscape, as people spread out to cultivate new areas. Possibly the most widely acknowledged and important site of all is Banua Puan, in Mengkendek, where the ancestor Tangdilino' is said to have built the first carved tongkonan to have been consecrated with rituals. ${ }^{4}$ Tangdilino' was not a to manurun, but was one of the earliest Toraja ancestors - in one genealogy I collected, he is shown as two, in another as eight, generations removed from the first human couple on earth. The site at Banua Puan is well remembered, though it has not had a house on it for centuries; it is still vacant, and has been kept clear by local Mengkendek descendants, although a church has been built close beside it. Most noble houses all over Tana Toraja can trace some link to Banua Puan; one informant, Pak Kila' (a member of the Parandangan $A d a^{\prime}$, an association of representatives of the Aluk to Dolo), described it as the penggarontosan (from garonto': base, trunk) - the original tongkonan from which all others derive. Even though no material structure has existed here for so long, Banua Puan has kept a vital place in oral memory.

The idea of the house as a substitute for written history was made explicit to me by one noble informant, Tandiruru of Alang-Alang. Unlike their neighbours of the Bugis and Makasar lowland kingdoms, Toraja never developed a written script of their own. But instead of the written chronicles which the Bugis and Makasar peoples recorded on strips of palm leaf (lontara'), Torajans, he pointed out, had the tongkonan. "History" here, as everywhere, serves particular purposes. It is a prerogative of the aristocracy, who were the only ones permitted to build elaborately carved houses, and the only ones with an interest in remembering long genealogies. Many of these genealogies contain the names of the protagonists of well-known mythical stories. Objects associated with some of these characters are preserved as powerful heirlooms inside the houses with which they are associated. Tongkonan and genealogy, used in the past as legitimating devices by the aristocracy, are still relevant today as the nobility of different areas compete with each other. Now the arena is one not simply of local but of national politics, and a newly commercializing economy. Those areas that can most convincingly present themselves as richest in "authentic" Toraja history and culture are in a better position to lay claim to a share of tourism 
development funds, to be used for the maintenance or renewal of origin-houses and the improvement of infrastructure such as roads. They may then look forward to an increasing number of wealthy foreign visitors passing through. Mythical ancestors and events, and finely carved houses to go with them, remain an essential ingredient of these contested histories.

\section{Houses and Their Myths: Connections With Lowland Kingdoms}

Some myths told in relation to the founding of particular houses also serve to situate Toraja in relation to their neighbours, the Bugis and Makasar peoples of the South Sulawesi lowlands. Several provide grounds for claiming precedence over what were objectively the much more powerful centralized and Islamicized kingdoms of South Sulawesi. The royal families of these kingdoms have intermarried with the Toraja nobility of certain areas over a long period, and indeed acknowledge their links to a Toraja ancestor, Laki Padada. Laki Padada is represented in several genealogies as a grandson of Tamboro Langi', one of Toraja's most famous to manurun. His father Puang Sanda Boro married a woman whom he discovered inside a bamboo; she was called To Bu'tu ri Pattung (One who Appeared from a Bamboo) or Puang Ao' Gading (Lady of the Bamboo). She gave birth to two children, a son, Laki Padada, and a daughter, Puang Mate Mangura or Puang Mate Malolo (both names mean Lady who Died Young). Distraught at his sister's death, Laki Padada vowed to travel the world in search of the secret of eternal life. His journeys eventually brought him to the Makasarese kingdom of Goa. ${ }^{5}$ Here after many adventures he married the ruler's daughter. Of their three sons, one, Pattala Merang, became the ruler of Goa; the second, Pattala Bunga, became the ruler of Luwu', while the third, Pattala Bantan, returned to Toraja and married Petimba Bulaan (Golden Dipper), variously depicted as the daughter or granddaughter of Manaek, founder of tongkonan Nonongan in Sanggalangi' district. Pattala Bantan went to Sangalla' and ruled over that part of Toraja known as the Tallu Lembangna or Three Districts of Ma'kale, Sangalla' and Mengkendek. These southern districts formed a federation, the closest Toraja ever came to emulating the centralized kingdoms of the lowlands. Later descendants of Laki Padada are said to have married into the royal family of Bone. These links are still acknowledged by the royal families of these lowland kingdoms, who have maintained a long tradition of intermarriage with Toraja nobility. ${ }^{6}$

Other tales recount how a Toraja "trickster" manages to outwit the Datu (ruler) of Luwu'. ${ }^{7}$ The tendency of these stories is to downplay the extent of Toraja subservience to Luwu' (regions closest to the borders of Luwu' paid some customary tribute as a sign of respect and in recognition of marriage ties, without, it seems, expecting any interference in their affairs), or even to claim a degree of precedence over Luwu'. One recurring theme concerns a hero, known in 
variants I collected in the Kesu' area as Tali Siba'ba, whose mother is a wild pig. He weds the female Datu of Luwu' and secretly installs his mother in the attic of the palace, forbidding the local populace to eat pork out of deference to her; this is claimed to account for why the people of Luwu' (who have been Muslim since the early seventeenth century) do not eat pork. In one version, the hero ends by changing his name to Karaenge Dua (Twice Noble), having become a noble of Luwu' as well as Toraja. An almost identical tale concerns the sons of Bonggakaradeng, a blacksmith who has given his name to the most westerly present-day kecamatan (district) of Tana Toraja; but in this case the story concerns relations with the Bugis area of Sawitto (present-day Pinrang), which borders on West Toraja and with which the Toraja regions of Bonggakaradeng and Simbuang have historically had close connections. ${ }^{8}$ Bonggakaradeng came from a village called Batu Tandung, near the Masuppu River. He was another person who found his wife inside a bamboo; her name was Datu Baringan, and she had a sister who was a python. Once while out in the forest on a hunting trip, Bonggakaradeng stopped to rest beneath an uru tree at a place called Pokka Uru on Buttu Karua (a mountain in Simbuang). He urinated on a fallen tree, unaware that in doing so, he had impregnated a spirit pig inside the tree. The pig gave birth to twin boys, Buttu Karua and Buttu Layuk. When they were about six years old, the mother sent them to look for their father, and they came to where Bonggakaradeng was working in his forge. They offered to help him in the forge, but he refused, not seeing how they could be of any use to him. But while he was eating his lunch in the house, they finished all his work for him, and to a standard exceeding his own. According to another version, they made a sword of gold (la'bo' penai bulawan) called Tonapa. This sword became a famous heirloom whose sheath is still kept in Sawitto, while the blade is in Simbuang. ${ }^{9}$ Eventually they persuaded the astonished Bonggakaradeng that he was indeed their father, and lived with him for a time, but, offended by his persistence in eating pork, they set off again by boat down the Masuppu River, taking their mother with them, until they reached Sawitto, where the pig-mother eventually turned into stone. ${ }^{10}$ They made magic there, causing the sky to go dark except around their own house, until the local people begged for an explanation. The brothers told them that they would bring back the sunlight if the people would agree henceforth always to show them various marks of respect, and to abstain from eating pork or the meat of any animal that died without being slaughtered. Thus the Bonenese became Muslim, while the two brothers married the daughters of a great aristocratic family, and had several children who became important ancestors in their turn. This is one of several tales told in justification of a saying in Simbuang: nene' Simbuang, appo Sawitto, or "Simbuang is the grandfather and Sawitto is the grandchild". Clearly this is an attempt to assert precedence over Sawitto, interesting because, just as in the case of Toraja-Luwu' relations, objectively Sawitto was a more powerful kingdom. According to Bigalke 
(1981:25), from the seventeenth to nineteenth centuries Simbuang was drawn into a tributary relationship to this small state; the Dutch, however, terminated this relationship by incorporating Simbuang into the administrative subdivision of $\mathrm{Ma}^{\prime}$ kale as a means of punishing Sawitto for its heavy resistance to Dutch forces.

In Sa'dan and Balusu, areas of northeast Toraja bordering on Luwu', a different story is told about an unusual hero from Sa'dan named Bulu Nanga (Hairy Penis). Bulu Nanga once travelled with a party of his followers and slaves to purchase buffaloes and salt in Palopo. The attendants of the Datu of Luwu' saw him bathing in the river and, catching sight of his remarkable appendage, made a report to the Datu. Bulu Nanga married the Datu's daughter, and his sword, called La Karurung, is said to be still kept in the palace at Palopo. Although these stories were no doubt told largely for local benefit, reference to myth can still be useful on occasion in interactions with lowlanders; an acquaintance recounted how on a visit to the provincial capital of Ujung Pandang, an elderly Toraja priest (to minaa), on meeting a Bugis government official, impressed the latter with his genealogical inquiries, by means of which he quickly established that the official must be the descendant of a mythical Toraja ancestor! $^{11}$

While these tales establish Bugis descent from Toraja heroes, some Toraja noble houses conversely claim descent from Bugis heroes. An example is Sawerigading, father of La Galigo, whose many adventures are recorded in the Bugis epic cycle of I La Galigo and known throughout Sulawesi (Kern 1989; Andi Zainal Abidin 1974). Such legitimating claims are made chiefly by the aristocracies of the districts adjoining Luwu', who have historically had, and still have, more contact with the former kingdom through intermarriage. I encountered examples both from Sa'dan and Balusu in the northeast, and from the southern federation of Ma'kale, Mengkendek and Sangalla'. A descendant of tongkonan Galugu Dua in Sa'dan district provided me with a written genealogy of sixteen generations, the founding figure of which is Andi Tendriabeng (Bug.: We Tendriabeng), Sawerigading's sister, shown as having married one Ramman di Langi' of tongkonan Punti in Sesean. ${ }^{12}$ Like other genealogies, this one includes the names of many other tongkonan founded by the descendants of this original couple. Five generations later, two brothers, both called Galugu (hence the present name of the settlement, Galugu Dua, meaning Two Galugus), are said to have been among the "Ancestors of the Same Dream" (Nene' Pada Tindo) who "held back the mountain of Bone" (untulak buntuna Bone), or resisted an invasion supposedly mounted by the ruler of Bone, Arung Palakka, in the mid-seventeenth century. ${ }^{13}$ Further south, I collected versions of the Sawerigading story from Tato' Dena' of Mandetek in Ma'kale — the To Minaa Sando or leading priest of the Aluk To Dolo; and from an elderly blind storyteller, Indo' Somba, of Kandora in 
Mengkendek - who was one of several informants providing detailed accounts to Salombe' (1975). Kandora seems to have established for itself a particularly strong association with Sawerigading, for a special "house" in the form of a rice-barn here at Potok Tengan contains stones, treasured as powerful heirlooms, which are said to be the petrified remains of La Pindakati of Cina, Sawerigading's first wife. ${ }^{14}$ The stones were brought here by La Pindakati's daughter Jamanlomo or Jamallomo, who married Puang Samang of Gasing (a mountain in Ma'kale district). In Salombe"s account, it is stressed that Jamallomo, being a descendant of Batara Guru, could only wed a man who was also a descendant of a to manurung or one descended from the heavens. Puang Samang, being a descendant of the Toraja to manurun Tamboro Langi', claimed in this region to have descended on Mount Kandora, proved an acceptable suitor. Jamallomo returned with him to Toraja, where they founded tongkonan Dulang at Potok Tengan (Salombe' 1975:276-277). A notable feature of the account given by Salombe' is the naming of particular places connected to the travels and deeds of the protagonists, names which survive to the present day. A place with a large mango tree is still called pao (mango), for example, while a spot where buffaloes were bathed is still called pa'burasan (place of foam) (Salombe' 1975:275). A local landscape is in this way given meaning in a manner familiar to us from many other societies. ${ }^{15}$

\section{Sky Men and Water Women: The to Manurun Ancestors}

In Tana Toraja, the idea of the to manurun, mythical beings who descended from the heavens on mountain tops and became local rulers, may have been borrowed from the Bugis, where legends of supernatural beings, the to manurung, are recounted in court chronicles, and are regarded by Noorduyn (1965) and Mattulada (1978) as having performed a legitimating function in the formation of lowland kingdoms during the thirteenth century. Toraja to manurun are always paired with an equally supernatural spouse, a woman who rose out of a river pool. People all over Toraja can trace their descent from one or another of these ancestors, though they appear to feature most prominently in southern, central and western areas. It is between these areas that competition over ancestors today appears to be keenest. The central Kesu' area claims To Manurun Puang ri Kesu' (Lord of Kesu) as its most important founding ancestor, while in the southern "Three States" (Tallu Lembangna), Tamboro Langi' is more important. The nobles in these two areas are far more status-conscious and had enjoyed more concentrated power in the past than those of the west, a region known for its egalitarian forms of address and more neighbourly ethos. Nobles from the two former districts would often express scorn at the idea of any significant ancestors coming from the west, although westerners disagree, and are anxious to gain more recognition for their own claims. A specific dispute concerns which particular mountain was the site on which Tamboro Langi' descended. According to traditions in the west, he landed on top of Ullin, a peak in Banga district, and 
founded a house there with his wife, Sanda Bilik, who rose out of a pool at the confluence of the Sa'dan and Saluputti Rivers. Ullin is also particularly associated with the deata, nature deities, who are said to congregate there annually after the harvest. Members of the southern states, however, tend to claim that Tamboro Langi' descended not at Ullin, in the west, but on Kandora, a dramatic peak that thrusts from the valley floor in Ma'kale district. Some versions say he later moved to Ullin, others that he lived only on Kandora and never went near the west at all.

Important houses in each area have their own stories about important ancestors and supernatural occurrences. The following examples were gathered in the westerly Saluputti region, particularly desa Malimbong, where I lived during my initial fieldwork. Ullin forms a triangle with two other mountain peaks visible from Malimbong: Sado'ko' and Messila. Next to Tamboro Langi' of Ullin, probably the most important ancestor in Saluputti genealogies is Gonggang Sado'ko', who is said to have descended on Sado'ko' and married a pool-woman, Marrin di Liku. In one account Gonggang is claimed to be the first human on earth in western Toraja, and is credited with sixteen children, some of whom bear the names of deities in the Toraja pantheon. The late Mangesa', former Kepala Desa of Malimbong (1965-71), who reckoned himself an eleventh-generation descendant of Gonggang, maintained that owing to his supernatural qualities, Gonggang enjoyed great longevity and was still alive at the time of Arung Palakka's invasion of Toraja, in the resistance to which, in Mangesa"s account, he played a leading role. But in the rather patchy genealogies that I collected from some present-day inhabitants of Ullin, he featured not as a to manurun at all, but as the grandson of Tamboro Langi'. The third mountain, Messila, is also associated with a to manurun, Kila' Ta'pa ri Ba'tang (Lightning Striking a Tree). Little is known about this ancestor, but according to Isaak Tandirerung, former District Head of Ulusalu, he descended somewhat later than Tamboro Langi'. He married a pool-woman and founded a house on Messila (which no longer exists), and their descendants later founded Pattan, the tongkonan layuk or "great house" of Ulusalu, from which Isaak himself was descended. In all three cases we find the same identification between the mountain and the mythical and long-vanished origin-house.

In desa Malimbong at the time of Dutch takeover, there were two rival noble families whose main origin-houses were at Pasang and Pokko', near Sawangan. Pasang's genealogy commences with Gonggang Sado'ko', Pokko"s with another remarkable ancestor, Pa'doran. Descendants of these two houses tended to magnify the importance of their own ancestor, while deriding stories about the other. Pa' doran is said to have been born two generations or so after Gonggang, but also to have commanded Gonggang's army in the war against Bone. He was not a to manurun, but a to mendeata, for he had received powers from the deities (deata) in a dream. He could walk several miles in a single step and had unnatural 
strength. If he stood on Sado'ko', he could reach Messila in a single stride, and with a third stand upon Ullin. He was held in awe, and like Gonggang, is said to have organized the people in matters relating to agriculture, warfare, adat and religion.

Several tales about $\mathrm{Pa}^{\prime}$ doran are related to local features of the landscape. Everything he said came to pass. When he said, "My buffalo is big", it at once became enormous, and when he said, "It will make a mountain with its horns", the buffalo tossed its head and ploughed two great furrows with its horns. The hill thus thrown up between them is called Buttu Susu, still a landmark in Malimbong. In another version, the tossing of the buffalo's horns threw up three villages - Buttu Susu, Bea and Matande; its droppings formed the mountain called Gattungan, near Buttu Susu. Pa' doran never married. He disliked the idea of rotting at death, and instead instructed his family to make a special basket for him. He then climbed into it and turned into stone. This basket is still stored in the tongkonan at Pokko', and can be viewed only if the appropriate offerings are made. The inhabitants claim that when an earth tremor is felt here, it means that $\mathrm{Pa}^{\prime}$ doran is descending from his basket to go out for a walk, and then a rattling as of coins can be heard inside the house.

One other to manurun in Malimbong was associated with the tongkonan at Parinding in Sa'tandung. Batotoilangi' (Appearing from the Sky) married a woman called Mandalan i Limbong (Deep in the Pool), who rose up out of a natural spring, which is still used as a water source today by the villagers of Parinding. They had eight children. One day, Batotoilangi' was offended by the smell of someone roasting dog meat, and returned to the sky, while his wife went back to her pool. Various taboos are associated with the house, not only on the eating of dog meat, but also of rat (field rats are occasionally consumed in some parts of Toraja), snails, or meat from funerals. It was also forbidden to spit on the site of the house. This founding couple, according to the inhabitants of the house, lived about eleven generations ago, at about the same time as Gonggang Sado'ko'. Before leaving, Batotoilangi' told the people that they would know he was still around when they heard thunder or when it rained. If ever a chicken is sacrificed here, even in the dry season, it is said that a light shower will fall. When there is a rainbow, it always appears with one end on the site of the original house, stretching over the banyan tree which grows beside it. If descendants of the house see a rainbow after making offerings, this is taken to mean that Batotoilangi' and the deata have received it. In the past, the house had many slaves attached to it, who all lived at the bottom of the hill on which it stood.

It is not hard to see how all these myths and stories, woven into the genealogies of politically powerful noble houses, served to elevate and justify the status of their inhabitants. The possession of powerful heirlooms connected 
to the stories further added to the mystique of these houses (or did, until members of the younger generation yielded to the temptation to sell some of these items to international art dealers). Whether their heroes were once real people, about whom tales were woven, or whether the stories were created first and the names later embedded in genealogies, is impossible to guess. Some, like Pa'doran or Batotoilangi', have highly localized reputations; others such as Tamboro Langi' or Laki Padada, have a fame that spreads more widely and links many descendant houses together. These links are periodically demonstrated and renewed in rites, as when in January 1983, over 100 groups of descendants of the famous tongkonan at Nonongan gathered to celebrate the rebuilding of the house. Not only can many Toraja trace connections to this house and its founder, Manaek, but so can the royal families of Luwu', Goa and Bone, all of whom sent representatives to the ceremony. The Luwu' party even brought a huge pig with them. Through their attendance they acknowledged their descent from Laki Padada, as well as their links through intermarriage with Toraja nobility.

\section{The "Ancestors of the Same Dream": Memories of Bugis Incursions}

The major events of oral history often have a distinctly mythical quality about them. At first I was puzzled by the apparent fusion of history and myth in the accounts I collected, the ability of my informants to engage in heated debate about the details of accounts that to me were clearly mythical, while at the same time infusing accounts of what might be historical events with mythical elements or what appeared to be folk tale motifs. Some informants elided and confused the details of separate historical incidents which happened hundreds of years apart. This, however, appears to be quite typical of social memory in oral societies. ${ }^{16}$ All the same, I would argue that anthropologists need to engage with history as historians understand it, as well as in terms of trying to understand their informants' conceptions of it. Anthropologists have often underestimated how much of the past may be knowable in non-literate societies, though this assumption has been radically changed by more recent studies. In the Toraja case, we are lucky to have the work of a skilled and sensitive historian, Terry Bigalke, to demonstrate just how much of the Toraja past is recoverable (Bigalke 1981). His study provides a most useful bench-mark for examining oral histories in Toraja.

The most prominent events in Toraja oral history again serve to situate Toraja in relation to their more powerful neighbours. They concern various military incursions of the Bugis into the highlands, which were successfully repulsed. The salience of these events has doubtless been heightened in recent times by the recurrence of hostilities during the troubled 1950s, when Bugis forces were twice driven out of Toraja. A "founding moment" seems to have been the struggle against the invading army of a king of Bone, identified in some versions as Arung 
Palakka, who ruled Bone in the late seventeenth century. ${ }^{17}$ In response to this threat, the headmen of Toraja settlements formed an alliance and swore an oath to stand together, the basse lepongan bulan (oath/alliance of the [region] as round as the moon). These leaders are called the Nene' Pada Tindo (Ancestors of the Same Dream) or to pada tindo, to misa' pangimpi (those of the same dream, those of the single destiny). Their short-lived federation is often cited by Toraja as the original source of a "Toraja" identity, but there is no evidence that it gave rise to any long-term political unity, in spite of living on in folk memory. Memories of this event are linked to the landscape in a number of ways, and though similar in form, show considerable local variation in content. They are cast in the form of a dramatic narrative, which tells how a misunderstanding arose between certain Toraja protagonists and the king of Bone. ${ }^{18}$ This gave rise to a battle in which a Toraja warrior, Pakila' Allo, was captured and cruelly tortured by the men of Bone. He however could not be killed, because he had a magic stone (balo') which made him invulnerable to iron. At last he was befriended by the king of Bone, and was given a beautiful lady to be his wife. Returning to Toraja, Pakila' Allo came to live at Randan Batu near Sangalla', where he became a tyrant, who abused and exploited the people, and even his own family, until at length they conspired to murder him. Their eventual success provoked his daughter to carry her complaint to the king of Bone, who sent his forces to extract vengeance from the Toraja. Their excesses in turn caused the "Ancestors of the Same Dream" to form their alliance. In this extraordinary story of cruelty and counter-cruelty, of treachery and betrayal, certain features always recur. One is the focus upon the character of Pakila' Allo, a Toraja who betrays his own people. Another is the idea of a night market, at which crows are sold instead of black cocks, cockatoos instead of white cocks, and a poisonous leaf (lelating) woven into mats which cause the user unexpected irritation. According to some, this market was a means by which the Toraja outwitted the Bugis (an inversion perhaps of the latter's historically dominant commercial role in the highlands); others say the market provided a distraction which prevented the Bugis from noticing the secret meetings of the Ancestors of the Same Dream as they planned their uprising. One person described the market as having been founded by Pakila' Allo himself as a way of enriching himself by attracting people to gamble all night. But a more intriguing explanation was that the market, organized by the Ancestors of the Same Dream, was intended as a warning to the deities, that unless they aided a Toraja victory, their offerings in future would be deliberately muddled up. The third recurrent feature is the description of the Bone troops as a multitude, described as pitu palo-palo (seven helmets). As they assembled for their assault on Toraja, each soldier placed a grain of maize into a large helmet, and they were so many that they filled seven helmets in this manner. Of the seven, only three (or, in some versions, one) of these palo-palo lived to return home after the Toraja uprising. 
The telling of the story always includes a long list of local village leaders (over 100 names in some places), with their places of origin (for example, Karasiak of Madandan), who attended a meeting and swore the oath to defend their homeland. These vary widely in different areas, with a concentration of local names being recalled in each place. Certain hilltops are also recalled as the places where torches were lit to send the signal for the uprising against the Bone troops. The site of the swearing of a "great oath" (basse kasalle) of peace between Bone and Toraja at the end of this war also differs. People in more central districts say that the oath was sworn at Bamba Puang in present-day Enrekang (south of the present border of Tana Toraja), where there is a mountain peak associated with local origin myths. But on a visit to the westernmost district of Simbuang in 1978, I was shown three small standing stones in front of the ancient tongkonan of Simbuang Tua which local residents say mark the spot. ${ }^{19}$ The people of Bone swore that henceforth they would enter Toraja only in peace; the oath curses them if they come in war, and can be ritually "woken up" (ditundan basse) to bring disaster on them if the promise is broken.

Sometimes the list of names and places is recalled without the complete story of events. I recorded one short account of the "Ancestors of the Same Dream" from an elderly to minaa, Saleda of Kinali in Talion, in January 1978. He had begun our interview by telling a creation myth, going on to recount a genealogy which began with a marriage between two ancestors renowned in the western part of Toraja, Gonggang Sado'ko' and Lai' Ullin. ${ }^{20}$ The genealogy comprises a list of descendants who subsequently spread out and travelled to different places in order to found new houses. Saleda then proceeded to explain about the Ancestors of the Same Dream as another important category of ancestors, and the roles they had played in establishing Toraja ritual communities. Rather than a historical account, the names of these ancestors, who "held back the mountain of Bone" (untulak buntuna Bone) in the past, are embedded in a litany which presents them as idealized founding figures, combining political and ritual leadership. It locates them in a sort of Golden Age, reiterating a vision of a time of abundance, when everything flourished and multiplied in response to the celebration of rituals. The account contains no details of the events of the Bone invasion, but rather creates a web of ancestors and the houses and ritual communities which they founded. Part of the text is given below:

Now, this story starts here in our village [region]: [it concerns] Gonggang Sado'ko', the Ancestors of the Same Dream, the Ancestors whom we revere as Lords. Gonggang Sado'ko' held back the mountain of Bone, in the olden days, he stopped their advance into our lands. Then the harvest of the earth flourished and human beings multiplied.

These were the Ancestors of the Same Dream: Pabidang lived at Buakayu; he, the ancestor who dwelt in Buakayu, he too joined in holding back 
the mountain of Bone, in the days gone by. He had responsibility for the [fertility of the] plains and hillsides; the offspring of buffaloes flourished, and human beings were born.

Masuang of Tangsa held back the mountain of Bone, he took care of the plains and hillsides in the days gone by, and everything flourished and was well. He it was.

Amba Bunga' of Ma'kale, Pong Songgo of Limbu, also held back the mountain of Bone in the past. Then the harvest of the earth flourished, people multiplied, everything grew in abundance. These were the Ancestors of the Same Dream, the Ancestors whom we revere as Lords.

Karasiak of Madandan likewise held back the mountain of Bone in the days gone by. He too. And the harvest of the earth was abundant at that time, and human beings multiplied.

Tandi of Lambun held back the mountain of Bone, he who passed down the rules of ritual (sukaran aluk) to the ancestors Sawalinggi and Rangkaianan. The rituals were upheld, and many feasts were celebrated. The merok feast was celebrated, the $b u a^{\prime}$ ceremony was completed.

Pong Manapa' of Bittuang held back the mountain of Bone in the days of the Ancestors revered as Lords. Then the upward-pointing horns [that is, buffaloes] multiplied in the dense forests, and cuscus passing by, and forest monkeys. ${ }^{21}$ Pauang of Malimbong, too, held back the mountain of Bone in the past. The harvests were abundant, nothing at all was wanting ... Those were our Ancestors of the Same Dream, in times past.

The ancestors are presented here as exemplary, not only in their resistance to the Bonenese intrusion but as founders of villages and upholders of ritual. ${ }^{22}$ In his recitation, Saleda greatly abbreviated the list of names, but stressed those who were closely associated with his own region. The network of place names is implicitly linked with the houses founded by noble ancestors in those locations. Just as in the recitation of genealogies, the founding of houses and their locations is woven in with the list of names, and forms an integral part of the information conveyed. The structure of the recitation, with its repetition of set phrases, clearly provides the sort of framework from which a skilled oral poet can generate an account which will be roughly similar though liable to variations on each particular telling. Such variations may not be perceived as relevant, if indeed they can be perceived at all by the performer and his audience. ${ }^{23}$

A second major Bugis incursion that is remembered in Toraja is the war that was fought in the highlands in the 1890s, when the Bugis court of Sidenreng set about trying to wrest control of the lucrative Toraja coffee trade away from the Datu of Luwu'. Instead of the coffee being transported to Luwu"s port at 
Palopo to the east, Sidenreng wanted the trade to flow to its own port at Pare-Pare in the west. Troops from Sidenreng, commanded by Ande Guru, entered Toraja from 1885 with some support from certain Toraja chiefs who saw their own interest in defying Luwu', and over the next ten years were largely successful in diverting the coffee trade. Luwu' eventually requested help from Bone, whose sovereign in 1897 sent a large force into the highlands via Palopo, led by his son the Patta Punggawa (Bigalke 1981:49-58). These troops, mounted on horseback and armed with modern rifles, live or in Toraja folk memory as the songkok borrong or "red caps". Although we are dealing here with a far more recent historical memory, about which some Dutch records also exist, and about which Bigalke was able to gather considerable oral data in Toraja, the stories that I collected were nonetheless confusing to me, because in several instances the events of this period seemed to have become confused with those of the Arung Palakka period, so that the term "Bone war" appeared to be applied indiscriminately to a sort of fusion of the two. This merging perhaps reflects simply the fact that the stories woven around the original historical events, whatever they were, have a similar meaning to people: they all concern relations of animosity with the Bugis. In the process, much longer periods in which relations were quite good tend to be overlooked. The happenings of the 1950s, which provided an occasion for a "waking up of the oath" all over Toraja, can then be seen as climactic events resonating with the earlier ones, and creating a new form of tension in the pressure to convert to Islam. ${ }^{24}$ Some Toraja were forced to join the guerillas and did convert; at the same time there was a flood of conversions to Christianity, either as a form of resistance and the assertion of a growing sense of ethnic identity, or as a defensive move in order to avoid guerilla accusations of "paganism". Toraja were particularly alienated by the latter's killing and mutilating of their pigs, and their aggressive efforts to make rejection of the pig the central feature of conversion to Islam (Bigalke 1981:434-435). The religious attitudes of this period may be seen to contrast with those around the turn of the century. At this time, almost all the leading Toraja chiefs could speak and write Bugis, some had sent their children to the court of Sidenreng for instruction, while a few, after years of contact with Islamic élites, were even considering converting to Islam (Bigalke 1981:69, 158). For all of the disruption caused by Bugis presence in the highlands, their trading of Toraja slaves to the lowlands, and the machinations of the various Toraja chiefs who formed alliances with them, religion had not then been at issue.

Detailed and more obviously historical local memories have been preserved about the events of the late nineteenth century. These concerned not just interactions with the Bugis but also inter-village warfare. Two prominent features of these memories have to do with the seizing of rice lands by the victors, the names of particular ricefields still being remembered, and secondly (a feature also of events of the 1950s), the burning of origin-houses. Many houses in 
Saluputti were lost in these periods; during the 1950s, people were caught between the two sides, as some houses were burned by the guerillas and others by Toraja forces of the Indonesian army (Tentara Nasional Indonesia) as retribution against villages where men had joined the guerilla forces. Collecting these stories provided a number of insights into the rise and fall of fortunes of particular houses, some of which had never been rebuilt after these disasters.

A number of features may be noted about these different kinds of memory. Fentress and Wickham (1992:113-114) have commented on the way "peasant" memory generally displays certain patterns cross-culturally. One of these is "the constantly recurring importance of local geography as a structure for remembrance"; secondly, we find both "the way memories are constructed outwards" from the individual to the family and community, in relationships both amicable and hostile - memories of family feuds, for example - but also memories "that represent the community's relationship to the outside world ... the imagery of the community of resistance ... and the various imageries of the Golden Age". This memory of the community in opposition to the outside world, they suggest, "is one of the most effective recourses any social group has to reinforce its own social identity in opposition to that of others ... Its very power means that it is not always authentic". Such memories tend to be recalled more tenaciously than other, less unifying events; their social relevance remains when other, less resonant events cease to be discussed and thus become forgotten. Here, perhaps, is the means to make some sense of the recurrent memories of resistance against Bugis incursors in Toraja folk memory, and their apparent blurring and fusion of distinct historical events into a single composite image. If assertion of community and identity is the real point of the stories, their historical accuracy is not really critical. They still contain a meaningful message, and a kind of truth. The outsider may find such memories historically confusing, but as Tonkin has observed, the activity of the professional historian who tries to reconstruct "what really happened" turns out to be only "a tiny proportion of historical action and discourse in any community", and a highly specialized one at that (Tonkin 1991:121).

\section{Conclusion: Ancestors, Precedence and the Division of Meat}

Many of the mythical, genealogical and historical memories I have examined here seem to have served a dual purpose: they have helped Toraja define themselves in relation to outsiders, and at the same time have been used in determining status relations within Toraja itself. Questions of precedence, either in internal or external relations, are important in all of them. Fox (1994:99) makes the useful observation that in Austronesian societies, such issues tend to be fluid rather than fixed, and are almost always disputed or open to challenge, either because more than one point of origin can be claimed as significant, or because 
precedence can be traced in more than one way, or because significant categories used to claim precedence can be manipulated. It is crucial therefore to inquire about the social contexts in which stories or genealogies are related, and to what purpose in the present. My concluding comments concern, firstly, the amount of variation in genealogies, and disputes connected to claims about the primacy of different ancestors, and secondly, the declaiming of the names of ancestors or origin houses at funeral meat distributions, which provide a most important public setting for the reiteration and confirmation of status claims.

What kind of time frame is encompassed in people's genealogies, and how are famous ancestors related to each other chronologically? Here we encounter as much flexibility as in most of the other details. Genealogies I collected showed a depth of anywhere between five and thirty-one generations between the teller and a founding ancestor. I am fairly sure that in some cases, if I had elicited a genealogy from the same individual on two separate occasions, I would have encountered some variation. The telling itself may vary depending on the context in which it is elicited, and such variations are not necessarily perceived as critical (if they can be perceived at all, in an oral context) by the persons concerned. There is, all the same, considerable congruence in some cases; for example the two main genealogies deriving from Gonggang Sado'ko' which I collected in Malimbong, from Malle' and from Mangesa', coincide very substantially, save for the omission of a single generation, and some minor variations of birth order, attributed gender, and spelling of names. Malle"s version also retains more siblings in each generation, most of which have been dropped from Mangesa"s. This suggests rather firm memorization of a consistent tradition which may well have considerable historical content. As with any use of genealogy as a historical source, assessing how accurate a history they may contain remains a question that, in the absence of alternative sources, is impossible to resolve. ${ }^{25}$

Where variation clearly does become politically significant in the present is where questions of precedence are involved. Which particular founding ancestor came first is the subject of sometimes heated debate. Kila', for example, argues that Tangdilino' must have preceded Tamboro Langi', since his grandchild Manaek married Tamboro Langi"s son, To Mambuli Buntu; and this is widely corroborated by other genealogical accounts in which these personages occupy stable positions in relation to each other. Tato' Dena' maintains that the two men lived contemporaneously. An informant from the Saluputti district, Pak Rante Sulu', claimed that on the contrary, Tangdilino' was a descendant of Tamboro Langi', adding that in his opinion, "The most important thing now is that Ullin should be recognized as far as Goa (the old Makasar kingdom) as the most original and important tongkonan in Toraja." This claim would appear to subordinate Banua Puan to Ullin, in an effort to boost the prestige of west Toraja. Its author teaches Toraja history and culture in the relatively new Tourism Training College (Sekolah Menengah Industri Parawisata) in Ma'kale - the only school in Toraja 
in which such a subject features on the curriculum. Tangdilintin's genealogy (in Nooy-Palm [1979]) confirms Kila"s account of the relation between Tamboro Langi' and Tangdilino', while showing the founder of Kesu', Manurun di Langi' Puang ri Kesu', as appearing one generation before Tangdilino'. All such variations may be contentious and are likely to be activated, at the present time, on occasions when descendants of different houses find themselves in any situation of competition with each other.

The division and distribution of meat at funerals is a key social moment in Toraja life, one which provides a visible and material commentary, continuously revised and reiterated, on the relative social standing of the participants. It can be fraught with tension, which has on rare occasions been known to explode in physical violence where a person believes himself to have been insulted by not receiving his due. More than any other procedure, this one establishes and maintains claims to precedence. Partly, one's prestige and the size of the share to which one is entitled depends upon the "boldness" of one's own sacrifices; the more pigs and buffaloes one is known to have slaughtered, the more meat one will receive. But it is also based upon inherited rank; the recitations of the meat-divider here become a repository of historical and genealogical memory, continually kept alive in performance and having real social consequences in the present. This task has traditionally been carried out by the ritual specialists (to minaa). For a long time the Toraja Church disapproved of it as a "pagan" element of the funeral rite which Christians were supposed to dispense with, but in recent years it seems that it has become more acceptable again, and has reappeared in Christian funerals, even if not performed by a to minaa.

The meat-divider, or to mentaa, stands on top of a tall platform, the bala' kayan, and recites a chant, calling out the names of a string of founding origin houses while throwing down their shares of meat. The precise houses named will differ from area to area, and the amount of meat distributed to them depends partly on the size of the funeral and whether there is any descendant present to collect it. Since key sites such as Banua Puan and Ullin have not had a house standing on them for centuries, the meat they receive may be only a token scrap (sangkarra'). But these scraps are nonetheless important as a reaffirmation of historical links. Kila', explaining how meat dividers in the northerly Sesean area will first call out the names of Banua Puan, Kesu' and Nonongan, remarked that this practice is called untundan basse ("waking up the oath"), which he expressed in Indonesian as membangkitkan sejarah, "arousing history", in other words bringing to life the historical link traced through remote lines of descent to these famous ancestral houses. To give meat along the correct paths to one's founding tongkonan he furthermore described as umbumbun garonto' tallang, "to strengthen the base of the bamboo-culm" (rapu tallang, "a bamboo culm", with its many shoots sprouting from a single base, is also an image used to refer to a bilateral kinship grouping); such prestations are not considered to create any debt. ${ }^{26}$ An 
elderly to minaa, Ne' Roya, at Siguntu' in Sanggalangi' district, recited the opening phrases of his meat-divider's chant which names Marinding (Banua Puan), Kesu' and Nonongan as the houses of the earliest ancestors, with many poetic phrases describing their exalted status. Kesu' for example is termed sikambi' panta'nakan lolo ("guardian of the seedbed of umbilical cords"), a phrase expressive of its importance as a place of human origins. By contrast, Pak Kondo, who sometimes performs the meat division in Banga (Saluputti district) said that here, Ullin would always be first named, and might receive a large share which would be taken by any descendant from Ullin who happened to be present; next would come Mebali (the tongkonan layuk or "great house" of Banga). ${ }^{27}$

Tato' Dena', who comes from Mandetek (in Ma'kale district), explained that there are three major categories of ancestors who may be remembered in the meat division. The number of ancestral houses named depends on the size and "level" of the funeral ceremony, measured by number of buffaloes, since this affects the amount of meat available for division. Most important of all are the two ancestors associated with the spreading of the aluk, the ritual prescriptions governing Toraja life, the nene' ussio' sukaran aluk. They are Tangdilino' of Banua Puan and Tamboro Langi' (of Kandora, in this version). Secondly, there are the nene' lumion tondok, the ancestors who established the boundaries of villages. These are principally the children and later descendants of Tangdilino' and Tamboro Langi', who travelled to different places where they founded houses of their own, as recalled in genealogies. Thirdly, there are the nene' to pada tindo, the Ancestors of the Same Dream. In this area, at a five-buffalo funeral (the lowest level to qualify for the recital), Banua Puan and Kandora in the south, Ullin in the west and Sesean in the north would be named, along with Tiang, Olang and Tangsa, origin-houses closer to Mandetek. But for a very high-ranking funeral, there would be much more meat available and all of the houses of the Ancestors of the Same Dream would be named. His chant would then go on to name locally important houses such as Tadongkon, Pangi and Deata, in the immediate environs of Mandetek.

This reveals to us the social significance of the Pakila' Allo story. Although I have been unable to determine the links between that story and actual historical events in Sulawesi, I am still left with the question of how and why the tale has been so tenaciously preserved. The account given to me by Pak Pasang Kanan confirms that of Tato' Dena', for it ends by explaining that all those who trace descent from the Ancestors of the Same Dream were given the right to have the story declaimed from the top of the meat-dividing platform at their highest-ranking funerals, with shares of meat to be distributed to the descendants of each named ancestor. If this was the context in which it has traditionally been recounted, then not only did this provide a regular occasion for retelling the story, but it also gave it a meaning in terms of present social relations. The 
significance of the story must be seen to rest at least partly in its continued relevance as a means of inscribing precedence and status in Toraja society.

Local variations on the meat-divider's performance, then, provide regular occasions for the public affirmation of certain historical ties, made visible by the distribution of meat either in the form of a token gesture, or more substantial shares, which in each locality trace both distant original ancestors, and more immediate ones. The ties of descent and kinship are always connected with the locations of named houses, however much variation there may be concerning which houses are named. Names of ancestors, and of the places they settled, are recalled together and remain intermeshed.

Ten years ago, there was talk among some of the descendants of Ullin about the possibility of rebuilding that house, though it came to nothing and instead a lesser branch house has been rebuilt. Part of the thinking behind this idea was that if Ullin were to be more widely recognized as a vital origin-site, then in future more tourists might come here, particularly if (as I was told in 1994) a major new highway is to be cut through from the airport at Rantetaio, passing right over the mountain. Currently, another plan is afoot to rebuild Banua Puan in Mengkendek. This is more likely to succeed for several reasons. First, it has the backing of a very wealthy and successful Mengkendek descendant who has made a career in Jakarta. Second, there is more widespread consensus about the significance of Banua Puan as an origin-site. Almost every member of the Toraja nobility can trace descent back to this house by some means, so that in theory the huge potential number of financial contributors would mean that only small amounts would be required from each of them. The problem is to find a co-ordinator who can be fully trusted to manage these funds. Whether anyone would actually take up residence in the house is another question. It seems certain that the house, even if "brought back to life" by rebuilding, will not function in quite the traditional manner. If the plan succeeds, it would serve not just to satisfy the sense of historical pride among Mengkendek descendants of Tangdilino', but as an added draw to tour groups to pay a visit to the site, and purchase souvenirs while they are there. Some novel suggestions have already been made for its use. The Parandangan $A d a^{\prime}$ (the association representing the remaining adherents of Aluk To Dolo), has expressed a special interest in the project; one of its members proposed that the house should be run by adherents of Aluk "as a place of prayer and a site for tourism and research into Toraja history and ancestors." This is a new departure in more ways than one, not least because Aluk has never had fixed places of worship. It is clear that if this plan to resurrect the house succeeds, it will be in order to turn it to new political, economic and religious purposes, reflecting the continuing dynamic tensions between old and new in Toraja culture. 


\section{References}

Andaya, L.

1975 The nature of kingship in Bone. In A. Reid and L. Castles (eds) Pre-colonial state systems in Southeast Asia, pp.115-125. Kuala Lumpur: MBRAS Monograph no. 6.

Andi Zainal Abidin

1974 The I La Galigo epic cycle of South Celebes and its diffusion. Indonesia 17:161-169.

Basso, K.

1992 Speaking with names: language and landscape among the Western Apache. In G. Marcus (ed.) Rereading cultural anthropology, pp.220-251. Durham/London: Duke University Press.

Bender, B.

1993 Stonehenge - contested landscapes (medieval to present-day). In B. Bender (ed.) Landscape: politics and perspectives, pp.245-279. Providence/Oxford: Berg.

Bigalke, T.

1981 A social history of "Tana Toraja", 1870-1965. PhD thesis, University of Wisconsin.

Bohannan, L.

1952 A genealogical charter. Africa 22:301-315.

Caldwell, I.

1988 South Sulawesi A.D. 1300-1600: ten Bugis texts. PhD thesis, The Australian National University.

Evans-Pritchard, E.E.

1939 Nuer time-reckoning. Africa 12:189-216.

Fentress, J. and C. Wickham

1992 Social memory. Oxford: Blackwell.

Fox, J.J.

1971a A Rotinese dynastic genealogy: structure and event. In T. Beidelman (ed.) The translation of culture, pp.37-77. London: Tavistock.

$1971 \mathrm{~b}$ Sister's child as plant: metaphors in an idiom of consanguinity. In R. Needham (ed.) Rethinking kinship and marriage, pp.219-252. London: Tavistock. 
1994 Reflections on "hierarchy" and "precedence". History and Anthropology 7(1-4):87-108.

1995 Origin structures and systems of precedence in the comparative study of Austronesian societies. Austronesian Studies August:27-57.

Hoskins, W.

1956 The making of the English landscape. London: Penguin.

Kern, R.A.

1989 I La Galigo. Yogyakarta: Gadjah Mada University Press.

Koubi, J.

1978 Il était une fois ... Lancêtre Lambe Susu, mythe Toraja sur le rapport richesse-hospitalité. Archipel 16:47-73.

1982 Rambu Solo, "La fumée descend": le culte des morts chez les Toradja du Sud. Paris: CNRS.

Küchler, S.

1993 Landscape as memory: the mapping of process and its representation in a Melanesian society. In B. Bender (ed.) Landscape: politics and perspectives, pp.85-105. Providence/Oxford: Berg.

Leach, E.

1954 Political systems of highland Burma. London: Bell.

Mattulada

1978 Pre-Islamic South Sulawesi. In H. Soebadio and C. Saarvas (eds) Dynamics of Indonesian history. Amsterdam: North-Holland.

Morphy, $\mathrm{H}$.

1993 Colonialism, history and the construction of place: the politics of landscape in Northern Australia. In B. Bender (ed.) Landscape: politics and perspectives, pp.205-243. Providence/Oxford: Berg.

Noorduyn, J.

1965 Origins of South Celebes historical writing. In Soedjatmoko (ed.) An introduction to Indonesian historiography. Ithaca: Cornell University Press.

Nooy-Palm, H.C.M.

1979 The Sadan Toraja: a study of their social life and religion. Vol. 1: Organisation, symbols and beliefs. The Hague: M. Nijhoff.

Olvig, K.

1993 Sexual cosmology: nation and landscape at the conceptual interstices of nature and culture, or what does landscape really mean? In B. Bender 
(ed.) Landscape: politics and perspectives, pp.307-343. Providence/Oxford: Berg.

Parmentier, R.

1987 The sacred remains: myth, history and polity in Belau. Chicago: University of Chicago Press.

Portelli, A.

1981 "The time of my life": functions of time in oral history. International Journal of Oral History 2/3:162-180.

Rosaldo, R.

1980 Ilongot headhunting 1883-1974: a study in society and history. Stanford: Stanford University Press.

Salombe', C.

1975 Une version orale du mythe de Sawerigading recueillie àKandora, Mengkendek, pays Toraja. Archipel 10:269-287.

Sugishima, T.

1994 Double descent, alliance, and botanical metaphors among the Lionese of Central Flores. Bijdragen tot de Taal-, Land-en Volkenkunde 150(1):146170 .

Tangdilintin, L.T.

1978 Toraja dan Kebudayaannya. Rantepao: Yayasan Lepongan Bulan.

Tonkin, E.

1991 Narrating our pasts. Cambridge: Cambridge University Press.

Volkman, T.

1985 Feasts of honor: ritual and change in the Toraja Highlands. Urbana: University of Illinois Press.

Waterson, R.

1984a Rites of east and west: ritual, gender and status in Tana Toraja. In R. Waterson, Ritual and belief among the Sadan Toraja. University of Kent Centre of Southeast Asian Studies, Occasional Paper 2:3-33.

1984b Taking the place of the ancestors: ethnic identity in Tana Toraja in the 1980s. In R. Waterson, Ritual and belief among the Sadan Toraja. University of Kent Centre of Southeast Asian Studies, Occasional Paper 2:3472.

1986 The ideology and terminology of kinship among the Sadan Toraja. Bijdragen tot de Taal-, Land-, en Volkenkunde 142(1):87-112. 
1990 The living house: an anthropology of architecture in Southeast Asia. Kuala Lumpur: Oxford University Press.

1992 Using houses as history in Tana Toraja, Sulawesi (Indonesia). PAPER (People and Physical Environment Research) 39-40:15-21.

1993 Houses and life processes in island Southeast Asia: the notion of semangat and the living house. Paper presented at the Workshop on Architectural Research in Small-Scale Societies of Southeast Asia, Center for NonWestern Studies, University of Leiden, The Netherlands, 2-3 December.

White, G.

1991 Identity through history: living stories in a Solomon Islands society. Cambridge: Cambridge University Press.

Yengoyan, A.

1985 Memory, myth, and history: traditional agriculture and structure in Mandaya society. In K. Hutterer et al. (eds) Cultural values and human ecology in Southeast Asia, pp.157-176. Michigan Papers on South and Southeast Asia no. 27. University of Michigan Center for South and Southeast Asian Studies.

\section{Notes}

1 This is particularly noticeable in works on Australian Aborigines (see Morphy 1993), but has also been dealt with with great sensitivity by ethnographers in some other areas, for example Basso (1992) for the Apache of North America, or Küchler (1993) on New Ireland. For analyses of the way in which memory is bound up with place, see especially Rosaldo (1980), Yengoyan (1985), Parmentier (1987) and White (1991).

2 My fieldwork in Tana Toraja was carried out over a period of eighteen months in 1978-79 with the help of a grant from the Social Science Research Council of the United Kingdom and for nine months in 1982-83 with the aid of grants from the British Academy and the Cambridge University Evans Fund. I am very grateful to these bodies for their support, and also to LIPI, the Indonesian Institute of Sciences, who gave their permission for the research. I visited Tana Toraja again in 1994 and 1996. I should like to thank Jim Fox for his helpful criticisms of earlier versions of this paper.

3 This latter term does not have a pair to indicate the branch house. On "trunk" and "tip", and other botanical metaphors in Indonesian kinship systems, see for example Fox (1971b), Waterson (1990:124-126), and Sugishima (1994).

4 Lino': "earthquake". The name Tangdilino' means "Cannot be Shaken".

5 Published versions of the Laki Padada myth can be found in Nooy-Palm (1979:148-153) and Koubi (1982:346-358).

6 According to Christian Pelras (personal communication), the Datu or ruler of Luwu' must have some Toraja blood in order to be an acceptable candidate for office, and traditionally wears a Toraja loincloth beneath his other garments at his investiture. The Puang (or ruling noble) of Sangalla' is always invited to such ceremonies, and has the unique privilege of ordering the Datu around, while all the other nobles present must treat him (or her) with the greatest deference.

7 See Volkman (1985:22) for an example. A variety of "trickster" tales feature a hero called Dana' or Dalana'i. He is often depicted as playing outrageous tricks on fellow-villagers and even his own parents. Bua' Sarungallo of Kesu' recounted some very amusing stories in which Kesu' outwitted both Luwu' and the rival district of Ma'kale. There is a kind of continuity between these stories and those that men sometimes enjoy telling about themselves, how by their wits they outface a competitor or puncture the arrogance of a more powerful or wealthy individual. 
8 The account given here is condensed from much longer versions of the Bonggakaradeng story which I collected in 1978 from Ambe' Sora of tongkonan Rea, and Indo' Lembang, the to manakka or female priest of Tondok Tanga', both in Simbuang. Another variant, given by Mappa', the elderly headman of Balepe', concerned a hero called Pokka Linoan, and demonstrated the precedence of the district known in Dutch times as Bau, over the adjoining Bugis-inhabited area of Enrekang. In this tale, one of the sons of Pokka Linoan marries a beautiful princess of Enrekang, who gives birth to Sawerigading and his twin sister (see below).

${ }^{9}$ The sword and sheath were divided at the making of the great oath (basse kasalle) after Arung Palakka's failed invasion of Toraja in the seventeenth century (see below). The blade is said to be kept at tongkonan Paken in Simbuang. If Bugis ever again invade Toraja, the sword can be taken out and given offerings, and when pointed directly at Sawitto and with the correct spells recited over it, will stand straight up and thus "awaken the oath" (ma'tundan basse).

10 In the Tali Siba'ba story, it was her trough that turned to stone and is said to be still in Luwu'.

11 Certain orientations may be maintained partly through details of everyday practice. According to Bua' Sarungallo, it is, or was, a habit of the aristocracy of Kesu' not to eat bananas that grow on the side of the trunk facing toward Luwu'; they milk their buffaloes with their backs to Luwu', and will not drink palm wine if the tube it drips through points toward Luwu'. Similarly, I was told in Simbuang that the aristocracy there refuse to eat bananas that grow pointing toward Sangalla'. Both these cases represent the acting out of a separation from, or denial of claims to precedence by, a potentially more powerful adversary.

12 Other mythical figures in this genealogy include Bua Lolo', the daughter of Lambe' Susu (see Koubi 1978), and Suloara', the legendary first priest or to minaa from Sesean.

13 This event is further discussed below.

14 Indo' Somba's version, like that published by Salombe' (1975), retains Sawerigading's origins as the grandson of Batara Guru (the first ruler of Luwu', descended from heaven). Tato' Dena's version, on the other hand, transposed the whole story to Toraja, explaining that Sawerigading and his twin sister had appeared from no-one knew where at Tengan (Kandora). In Salombe"s version, Pindakati came from Biduk, on the slopes of Mount Latimojong. It was his second wife, Lisudai (Bug.: We Cudai) who was from Cina. This accords with Bugis versions. (It is possible that the variation is due simply to the twenty years or more that have elapsed between Salombe"s interviews and mine with the same informant (see also Portelli 1981:164).) Lack of familiarity with Bugis history and geography results in a more curious transposition. Indo' Somba was insistent that "Cina" referred to the People's Republic of China, although in fact Cina was one of the earliest Bugis chiefdoms, most probably situated at the mouth of the Cenrana River, on the border of present-day Wajo' and Bone (Caldwell 1988:207-211).

15 Interestingly, although Indo' Somba knew such a wealth of detail about the history and myths attached to the houses of Kandora, she mentioned only in passing the name of Manaek, the Datu Baine or "Female Lord" who founded tongkonan Nonongan and who is such a prominent ancestor in the Kesu' region. She mentioned a saying to the effect that the people of Kandora also traced descent from Manaek, and that this must not be forgotten or they would be struck by lightning; but she thought Manaek was a man, and her husband, Ondo Ira, was a woman; she knew little else about them. I take this as evidence of how localized even the knowledge of local experts is about matters of genealogy and myth (see Nooy-Palm 1979:153-154).

16 Fentress and Wickham (1992:82), for example, observe that "[t]here is no inherent incompatibility between memory and genealogy, or, indeed, between either of the two and true narrative history ... As a rule, oral tradition combines mythology, genealogy and narrative history rather than holding them apart." Similarly, Yengoyan (1985:172) writes of the Mandaya of the Philippines that "myth and history are combined to provide cultural coherence, which, when reproduced through time and space, articulates the past with the present." For the Mandaya, physical locations in the landscape, and also plants, particularly fruit trees planted by remembered individuals, are important mnemonic devices. Sometimes events (of past battles) will be re-enacted and sung about upon arriving at a particular clearing in the forest. As the stories are repeatedly recalled and embroidered, they become timeless. Yengoyan stresses that "the meaningfulness of these activities is not vested in the fact that they occurred in the past", and therefore "memory creates a form of history that collapses the immediate past into the present." Although Toraja do not seem to image history as forming quite the same recurrent patterns as the Mandaya do, the apparent fusion of separate events should probably not be regarded as abnormal.

17 Arung Palakka ascended the throne in 1672 and died in 1696 (Andaya 1975). Tangdilintin (1978:44) gives the date of the invasion as 1675 , which is plausible, though no evidence is offered for it. Bigalke (1981:15) follows Nooy-Palm's brief mention of Toraja resistance to an invasion by Arung Palakka 
(Nooy-Palm 1979:60), though Nooy-Palm unfortunately does not mention her sources here. Bigalke states his belief that the events described in oral memory are based on actual historical circumstances but not all Toraja today seem convinced that the king of Bone who features in the story was necessarily Arung Palakka.

18 The following summary is drawn from a complete version of this story given to me by Pak Paulus Pasang Kanan of Sangalla' in June 1996.

19 There is always the possibility that two or more oaths were sworn. Since Simbuang borders on the Bugis region of Sawitto, the part played by the Sawitto people in this war features more prominently in their memories.

20 They are not always considered to have married each other, however. As already discussed, genealogies in this area tended to show wide variation.

21 "Cuscus" and "monkeys" here refer metaphorically to buffaloes.

22 Tato' Dena' explained that after the defeat of Bone, the Ancestors of the Same Dream celebrated many rituals in order to restore harmony to the earth.

23 See Fentress and Wickham (1992:43-44) for a detailed discussion of the process of oral composition as practised by Greek, Anglo-Saxon and Serbo-Croat bards.

24 See Bigalke (1981) for a detailed account of this period.

25 That genealogies structure time in a particular way for particular kinds of kinship system, and above all serve to validate present relationships, is an insight about which anthropologists have long been in agreement (Evans-Pritchard 1939:212; Bohannan 1952:314; Leach 1954:127-128). Fox (1971a), however, has effectively demonstrated that, where alternative historical records are available, the historical information preserved in genealogies can sometimes be shown to be very considerable. Such historical depth is unfortunately missing in written records concerning Toraja, so my concern has been more with the social reality of these accounts and their continued salience in present-day political life.

26 He further commented that Christians often "forget", or do not wish to remember, to give these shares of meat, claiming that they are part of the aluk ("religious" prescriptions) rather than adat (or permissible "custom"). Christians are not supposed to employ the services of a to minaa and so the meat distribution at a Christian funeral may be carried out by someone else whose performance will not be considered complete by traditionalists. In this way, as other informants also commented, a mode of enacting historical memory is also lost.

27 Mebali is linked to Ullin by a story which attributes its founding to a daughter of Tamboro Langi'. One day while pounding rice on Mt Ullin, the sound of her pestle echoed back to her from Mebali (lit. "to answer"), so she moved to that spot and founded tongkonan Appang Bassi there. The name of this house means "iron threshold", a reference to an heirloom object apparently long since lost. 


\title{
Chapter 5. Genealogy and Topogeny: Towards an ethnography of Rotinese ritual place names
}

\author{
James J. Fox
}

\section{Introduction}

Initially, I wish to introduce the notion of "topogeny". By "topogeny" I refer to an ordered succession of place names. I see the recitation of a topogeny as analogous to the recitation of a genealogy. Both consist of an ordered succession of names that establish precedence in relation to a particular starting point - a point of origin. In the case of a topogeny, genealogy, this is a succession of personal names; in the case of a topogeny, this is a succession of place names. Whereas considerable attention has been directed to the study of the significant genealogies, little attention has been given to the study of the recitation of place names. In eastern Indonesia, and among Austronesian-speaking populations in general, topogenies are as common as genealogies. Generally these topogenies assume the form of a journey: that of an ancestor, an origin group or an object. Often, however, it is difficult to distinguish place names from personal names and both cohere to form a combination of genealogy and topogeny.

Certain Austronesian societies give preference to topogeny over genealogy. Other Austronesians rely on both such ordering structures but confine themselves to different contexts. Too often, however, topogenies are disregarded as all but unintelligible prefaces to narratives. The variety of forms such topogenies assume is largely overlooked as are the contexts in which such topogenies are given. Indeed one of the critical comparative questions is in what cultural contexts genealogies are cited (as opposed to topogenies) as specific narrative devices among different Austronesian populations. This paper explores some of these issues as they apply to the Rotinese of eastern Indonesia. At the same time, it provides some explication of the use of place names in a particular form of Rotinese topogeny.

On Roti, personhood cannot be explicated without reference to place. Places may take on the attributes of persons, and persons the attributes of place. The interconnection is basic and thus place names can provide a useful starting point for the study of proper names.

The complexity that such names pose necessitates approaches from several directions. In this paper I examine aspects of the ethnography of Rotinese proper names by focusing on the use of place names in ritual language. Although this 
examination may appear tangential to the issue of personal names, it is in fact crucial to an ethnography of Rotinese naming.

\section{The Rotinese Context}

The Rotinese have developed both elaborate genealogies and elaborate topogenies. Each of the eighteen domains (nusak) on the island has its own genealogy, which is centred on the dynastic line of that domain's ruler. This genealogy could be expanded to embrace the high nobles of the domain and, in some areas, to provide links to the founders of the domain's constituent clans. Such genealogies can extend to thirty-six or more generations and, as far as can be documented in the case of the domain rulers, were preserved orally with remarkable accuracy (see Fox 1971a). Generally, for members of commoner clans, genealogies were of less importance and were not greatly elaborated. The dynastic genealogies of each domain provided the structure for extensive political narratives that recounted the origin and development of the domain. This genre of oral narrative is told exclusively in the dialect of the particular domain.

By contrast, the elaboration of topogenies among the Rotinese occurs only in ritual language accounts of the origin of particular culturally important objects. These are "origin accounts", like virtually all other ritual language chants, but their purpose is also to account for the spread of particular objects. Hence they consist of a recitation of the place names of the island. Thus unlike genealogies which are generally concentrated, even in ritual language performances, at the beginning of a recitation, recounting of topogenies may require an entire recitation.

All topogenies must conform to the requirements of ritual language. Thus all places referred to in ritual language must have double names. Knowing the ordinary name of a place may provide a clue to its dyadic ritual name, but often the connection between the two is minimal. Ritual names, however, are not secret names. Such names are generally common knowledge and provide a further dimension to the knowledge about particular places. Knowledge of the ritual names of numerous sites is a specialization, confined to chanters who pride themselves on their ability to recite long ritual language narratives.

\section{Names and the Cosmology of Place}

The cosmology of the compositions in ritual language consists of three worlds. There is first a heavenly world which is referred to as Poin do Lain, or occasionally as Ata do Lain, "The Heavens and the Heights". This is the world presided over by the Sun and Moon. In opposition to this world is the world beneath the sea which is referred to as Liun do Sain, "The Ocean and the Sea". This world is the realm of the Mane Tua Sain ma Danga Lena Liun, "The Great Lord of the Ocean and the Chief Hunter of the Sea" whose personification is the 
Shark and Crocodile. Between these worlds is the earth, referred to as Dae Bafak ma Batu Poin, literally "The Earth's Mouth and the Rock's Point".

The identity of characters in these three worlds is often revealed in their names. Heavenly Creatures have names that include the terms for the sun, moon, stars or heavenly phenomena such as the rainbow or lightning. Thus there are names such as Patola Bulan ma Mendeti Ledo or Fudu Kea Ledo ma Tao Senge Bulan. By linking different chants, it is possible to detect a genealogical structure linking some of the descendants of the Sun and Moon (Fox 1997).

Creatures of the Sea are identified by the terms "sea" and "ocean" in their names or simply as Creatures of the Sea who form the retinue of the Lord of the Sea. Thus there are characters in the chants with names such as Lada Liuk ma Lole Saik, "Ocean Goodness and Sea Tastiness" or names such as Pata Iuk ma Dula Foek, "Figure Shark and Pattern Crocodile".

Creatures of the Earth are far more numerous and their names far more complex. Many names include the terms for earth, rock, river, water - all of which serve as markers for specific places. Thus personal names are specifically linked to place.

\section{The Names of Roti and the Symbolic Co-ordinates of Place}

A place may have more than one ritual name and such names may have a simple and a more elaborate form. Thus, for example, the most common ritual name for the island of Roti (Lote in Termanu dialect) is Lote do Kale. However, this name may be elaborated as Lote Lolo Ei ma Kale Ifa Lima, "Lote of the Outstretched Legs and Kale of the Folded Arms". The image is one of rest; legs stretched out and arms folded in the lap. Another name for the island that invokes a similar sense is Lino do Ne, "Quiet and Peace". Yet another name for Roti, which was once current but is now rejected as inappropriate, is Ingu Manasongo Nitu ma Nusa Manatangu Mula, "The Land that Offers to the Spirits and the Island that Sacrifices to the Ghosts". Roti's population is now almost entirely Christian and hence this name is no longer considered suitable. It is a name from the past.

The island of Roti is conceived of as having a "head" (langa) and a "tail" (iko); a "right" side (kona) and a "left" side ( $k i)$. The "head" of the island is in the east (dulu), its "tail" in the west (muli). The "right" side of the island is to the south, the "left" side to the north. Reflecting on these co-ordinates, some Rotinese contend that their island is like an immense crocodile resting in the sea with its head raised slightly higher than its tail.

These co-ordinates are regularly used to identify places on and beyond the island. A few examples of place names composed of these co-ordinates may illustrate the underlying system. The island of Savu to the west of the island of Roti figures in Rotinese ritual chants. Because it is to the west, it is referred to as Seba Iko ma Safu Muli, "Seba of the Tail and Savu of the West". The same 
categories (west//tail) are applied to the westernmost domain on Roti, the domain of Delha, which is referred to, in ritual language, as Dela Muli ma Ana Iko, "Dela of the West and Child of the Tail". By contrast, one of the ritual names of the domain of Diu is Diu Dulu ma Kana Langa, "Diu of the East and Kana of the Head". One of the names of Thie, a domain in the southern and central part of the island, is Tada Muli ma Lene Kona, "West Tada and South Kona".

\section{The Ritual Names of the Domain of Termanu}

Currently the most common name for Termanu is Koli do Buna. The following six-line parallel poem aptly illustrates the use of this name:

\section{Koli nai talada}

Buna nai use boson

Te'o nai tutulin

Ina nai laladin

De lope tuli te'o dae

Ma lao ladi ina dae.
Koli at the centre

Buna at the navel

An aunt at the halting place

A mother at the place to pause

As you go, halt at your aunt earth

And, as you pass, pause at your mother earth.

Koli do Buna can also form part of a more complex set of names. Thus Koli do Buna can become Koli Dale do Buna Dale, "Inside Koli or Inside Buna" or Lima Koli do Ei Buna, "The Arms of Koli or Legs of Buna". Koli do Buna is, however, only the latest in a succession of names.

One of the most interesting features of ritual names is their historical dimension. Certain important sites may have a series of names that form a historical succession. Each name may thus be commemorative of a particular period or event. The ritual names of the domain of Termanu provide a good illustration of this historical succession of names.

Termanu has had at least five other earlier ritual names, each commemorating a stage in the extension of the domain and its prosperity:

1. Sina Seo ma Mau Daka

2. Ngginu Ia ma Ngganu Pa

3. Pesa Nesu ma Te Alu

4. Pinga Dale ma Nggusi Bui

5. Pada Kode do So Meo

Each one of these names carries a great weight of local exegesis. Thus the first, Sina Seo ma Mau Daka, refers to the warlike exploits of certain clans in the initial expansion of the domain. The second, Ngginu Ia ma Ngganu Pa, refers to containers for fish and meat, and alludes to a kind of rich, pre-agricultural period in the domain's early history. The name defines a specific phase in the development of the domain that coincides with the deeds of particular ancestors. 
Similarly, the third name, Pesa Nesu ma Te Alu, refers to the pounding of rice, thus alluding to the opening of new sources of irrigation in the south and east of the domain. Pinga Dale ma Nggusi Bui alludes to the incorporation of irrigated rice areas in the region south of Fea Popi, the centre of the domain, while Pada Kode do So Meo, "Monkey-Pada or Cat-Oath", alludes to the period following Termanu's bitterest dynastic dispute.

In short, ritual place names can succeed each other, almost as personal names in a genealogy do.

\section{Narrative Topogeny: The Chant of the Origin of Rice and Millet}

Some ritual chants consist almost entirely of topogenies. They provide an opportunity for the successive recitation of place names throughout the island. The most important of these topogeny chants recounts the origin of rice and millet. The chant is identified by the names Doli do Lutu or Doli Mo ma Lutu Mala, which are the ritual names for rice and millet, or alternatively by the names of the creatures of the sea that become rice and millet, Bole Sou ma Asa Nao. The background explanation for the arrival of these creatures on Roti (in the two versions of the chant which I have gathered) is so brief and tantalizingly cryptic that it is difficult to provide extensive exegesis. In one version, the explanation of the "origin" of rice and millet forms a kind of preface of some eighteen lines out of a total of over two hundred and eighty lines. ${ }^{1}$ The chant is as follows:

1. Touk leo Bole Sou

2. Ma taek leo Asa Nao

3. Ala ke bibia iu

4. Ma ala tati momola foe.

5. Boe ma iu neu namanasa

6. Ma foe ana nggenggele.

7. Hu ndia de tasi lu Asa Nao

8. Ma oli lama Bole Sou.

9. Boe te lu neni Doli Mo

10. Ma lama neni Lutu Mala.

11. De nenin neu Mae Oe

12. Ma nenin neu Tena Lai

13. Fo Mae Oe Loek lutun

14. Ma Tena Lai Laok dean.

15. Besak-ka nupu non na dadi

16. Ma sadu puan na tola
The man like Bole Sou

And the boy like Asa Nao

They cut and hack the shark

And they slash and slice the crocodile.

Then the shark grows angry

And the crocodile becomes furious.

At this the sea rises with Asa Nao

And the estuary lifts Bole Sou.

So the tide carries Doli Mo

And the flow carries Lutu Mala.

It carries him to Mae Oe

And carries him to Tena Lai

To the fish-catch at Mae Oe Loek

And to the sea-wall at Tena Lai Laok.

Now the coconut shoots begin to grow

And the pinang shoots begin to appear 

17. De li lakadodofun
18. Ma nafa lapopolin.
The waves cover him
And the surf soaks him.

Both Rotinese exegesis on this version of the chant and lines in a subsequently recorded version identified Bole Sou and Asa Nao as a "small shrimp and tiny

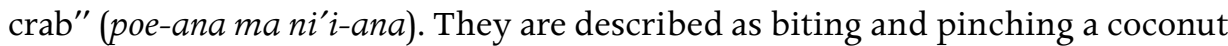
and areca nut that carry them bobbing in the sea to the shores of Roti at a place called Tena Lai ma Mae Oe. This ritual site is located in the domain of Landu at the far eastern end of the island.

From Tena Lai ma Mae Oe, the topogeny begins and proceeds in a counter-clockwise cycle around the island: first toward the western end of the island, along the north coast and then back to the east along the south coast, returning finally to Tena Lai ma Mae Oe. This cycle is conducted by some women who successively pick up Doli do Lutu and carry them to a new field and plant them. Thus each name cited in the topogeny is supposed to be the name of a rice and millet field.

The versions of this chant that I have gathered come from the domain of Termanu. For Termanu, each name cited is indeed a rice field complex known as a lala. The names of other sites in more distant domains are in fact the most widely known names of these domains. In some cases, these names are not specific names of fields but general designations of the domains. However, in terms of the topogeny, all such names are described as they referred to rice or millet fields.

The chant is highly repetitious since each successive movement of the rice and millet follows a similar formulaic phrasing. A crucial feature of the chant is the close identification of women with specific fields. In some cases, women's names are a variant of the field name; in other cases, the identity of woman and field is assumed to the extent that only the women's names are cited. References to particular fields are implied.

Initially, in the chant, the planted rice and millet do not grow. The first woman to encounter Doli do Lutu (Bole Sou ma Asa Nao) bears the dual name Masu Pasu ma He Hai. She carries the rice and millet from Tena Lai ma Mai Oe to a field in the domain of Korbaffo, which takes its ritual name from its large bay, Tunga Oli ma Namo Ina (Follow the Inlet and Mother Harbour). These lines of the chant follow:

19. Faik esa ma-nunin

20. Ma ledo esa ma-teben

21. Tasi la huka papa

22. Ma meti la si unu.

23. Boe te inak-ka Masu Pasu
On one certain day

And at a particular time

The sea opens its planks

And the tide tears wide its slats.

So the woman, Masu Pasu 
24. Ma fetok-ka He Hai

25. Neu nafadama lutu limak

26. Ma nafaloe dea eik.

27. Boe to neu nda lilima

28. Ma neu tongo lololo.

29. Doli Mo nasakedu

30. Ma Lutu Mala namatani

31. Fo nasakedu sanga inan

32. Ma namatani sanga teon,

33. Te hu inan nai Asa Nao

34. Ma teon nai Bole Sou.

35. Besak-ka inak-ka, Masu Pasu

36. Ma fetok-ka, He Hai neu.

37. Ifa neni falik Doli

38. Ma koo neni tulek Lutu

39. De tulek Asa Nao

40. Ma falik Bole Sou.

41. Mai bei nai Tunga Oli na Namo Ina.

42. De sele lakaboboin

43. Ma tane lasamamaon

44. Te hu bokon ta dadi

45. Ma do belan ta tola.
And the girl, He Hai

Goes to probe the arms of the fish-catch

And goes to grope at the foot of the seawall.

There they encounter [Doli Mo]

And there they meet [Lutu Mala].

Doli Mo is sobbing

And Lutu Mala is crying

Sobbing for his mother

And crying for his aunt,

A mother to Asa Nao

And an aunt to Bole Sou.

Then the woman, Masu Pasu,

And the girl, He Hai, goes [there].

Returns carrying Doli in her lap

And comes back cradling Lutu in her arms

She brings back Asa Nao

And returns Bole Sou.

She arrives at Tunga Oli and Namo Ina.

They plant him with care

And they sow him with attention

But the bending stalk does not grow

And the heavy leaves do not appear.

It is at this stage that the rice and millet are carried to Termanu by the woman, Fi Bau ma Seda Kola, and planted in the field, Bau Peda Dele ma Kola Sifi Ndai, the first of a series of rice fields where initially rice and millet do not grow. This segment of the chant is as follows:

46. Besak-ka inak-ka Fi Bau

47. Ma fetok-ka Seda Kola

48. Ko'o do ifa nenin.

49. De sele nakaboboin

50. Ma tane nasamamaon

51. Nai Bau Peda Dele fuan

52. Ma Kola Sifi Ndai mon,

53. Te do belan ta dadi

54. Ma hu bokon ta tola.
Now the woman, Fi Bau,

And the girl, Seda Kola,

Cradles or carries him away.

She plants him with care

And sows him with attention

In the field at Bau Peda Dele

And in the plain at Kola Sifi Ndai,

But the heavy leaves do not grow

And the bending stalk does not appear. 
A succession of women - Kada Ufa ma Dila Latu, Hau Hala ma Kae Kopa, Leli Onge ma Fula Fopo and Soe Leli ma Pinga Pasa - each of whom can be identified with the site of a particular field complex on Termanu's north coast - come forward, take the rice and millet, and plant them; they do not succeed in getting them to grow. It is only when the woman, Lole Bako ma Fiti Nggoli, carries them with full ceremony and plants them in the field named Bako Bau Dale ma Nggoli Kai Tio that the rice and millet finally sprout and grow. This sequence of the chant is as follows:

\section{Besak-ka inak-ka Fiti Nggol \\ 84. Ma fetok-ka Lole Bako \\ 85. Ana tolo mu sasali \\ 86. Ma nalai lelena.}

87. De neni pua lisu lasi boak

88. Ma malu boa dongi aik

89. Pou leu pana-daik

90. Ma sidi soti tola-teek.

91. Mai de ana ifa so ko'o nenin.

92. De neu tane nasamamaon

93. Do sele nakaboboin

94. Neu Bako Bau Dale mon

95. Ma neu Nggoli Kai Tio fuan

96. Ma ana mole sepe do fua oli.

97. Besak-ka kalen-na didiku

98. Ma pulen-na loloso.

99. Boe ma besak-ka oku-bolu ma do-seek

100. Nai Bako Bau Dale mon

101. Do Nggoli Kai Tio fuan.
Now the woman, Fiti Nggoli,

And the girl, Lole Bako,

She comes running

And she comes dashing.

She brings an areca nut round as a bowed cotton ball

And a betel fruit long as a barbed spear shaft A sarong with pana-daik bands

And a ritual cloth with the tola-teek stitches.

Coming, she carries or cradles him away.

She goes to sow him with attention

And plant him with care

In the plain of Bako Bau Dale

And in the field of Nggoli Kai Tio

And she celebrates the sepe-basket and lays the oli-basket [rituals].

Now his kernel bends over

And his buds creep upward.

Now they yell and make noise [to drive away the birds]

In the plain of Bako Bau Dale

And in the field of Nggoli Kai Tio.

After this success, two more women from Termanu, Dulu Kilik ma Leo Lasuk and Pinga Peto ma Lu'a Lela, take the rice and millet and sow them in the field complexes of Ki Lama ma Le Ina and of Peto Lesi Ama ma Lela Bala Fia. Again the grains sprout and grow.

This is the last of the sequence of named rice fields in Termanu. After this the chant proceeds to describe the transference of the seeds and their planting in a circuit through the Roti domains. A brief segment for the domain of Loleh is sufficient to illustrate the repeated formula of the chant. Here the chant refers 
to Loleh by its two most commonly known ritual names, Ninga Ladi ma Heu Hena and Teke Dua ma Finga Telu.

174. Boe ma inak bei Ninga Ladi The woman of Ninga Ladi

175. Ma fetok bei Heu Hena

176. Inak bei Teke Dua

177. Ma fetok bei Finga Telu

178. Inak-ka Tui Beba

179. Do fetok-ka Oe Ange

180. Ana if a do ko'o nenin.

181. De ana sele do tane
And the girl of Heu Hena

The woman of Teke Dua

And the girl of Finga Telu

The woman, Tui Beba,

Or the girl, Oe Ange,

She carries or cradles him away.

She plants or sows

182. Neu Ninga Ladi do Heu Hena. In Ninga Ladi or Heu Hena.

183. De oku boluk ma do-seek. They yell and make noise.

Finally, after completing a circuit of the island, Doli and Lutu are returned to the Tena Lai ma Mae Oe where they began by a woman identified with the domain of Landu. The chant concludes with the lines:

275. Boe ma feto bei Soti Mori

276. Ma ina bei Bola Tena

277. Inak-ka Liti Lifu

278. Do fetok-ka Henu Helok

279. De ifa do ko'o nenin

280. Ko'o mangananaun

281. Ma ifa tapandondoen.

282. De ana tane do sele

283. Neu Tena Lai do Mae Oe.

284. Te fuak ta Tena Lai

285. Ma mok ta Mae Oe.
A girl of Soti Mori

And a woman of Bola Tena

The woman, Liti Lifu,

Or the girl, Henu Helok,

She carries or cradles him away

Cradles him gently in her arms

And carries him tenderly on her lap.

She sows or plants

At Tena Lai or Mae Oe.

But there is no field at Tena Lai

And there is no plain at Mae Oe.

286. Boe ma ana tulek leo liun neu Then he goes back to the ocean

287. Ma falik leo sain neu.

And returns to the sea.

\section{Mapping the Path of Rice and Millet onto the Body of the Island}

Topogenies take various forms, defining different paths. The path of Doli do Lutu, for example, differs from that of the path of the great rocks of Sua Lai and Batu Hun that stand as the coastal landmarks of the domain of Termanu. These topogenies differ in their points of origin and of termination and, even more significantly, in the trajectories of their individual paths. The topogeny of Sua Lai and Batu Hun has its origin in Termanu; the trajectory of the path it narrates 
proceeds eastward to the island of Timor where a transformation occurs that directs the journey of the two rocks back westward to a point - Pao Kala ma Peni Kea - at the southeastern end of Roti. From there, the path of the rocks follows a clockwise movement along Roti's south coast and eventually back to the rocks' "ancestral harbour" in Termanu on Roti's north coast. By contrast, the topogeny of Doli do Lutu begins at Tena Lai ma Mae Oe - at the eastern end of Roti. The path of rice and millet involves a counter-clockwise circumambulation of the island from the "head" to the "tail" of the island, with a return to the place of origin at the head.

Just as any topogeny can be defined by its point of origin and termination, it can also be defined by the named places that mark the path between origin and termination. The topogeny of Doli do Lutu in this paper consists of a recitation of thirty-two ritual place names, all of which can be mapped onto the body of the island.

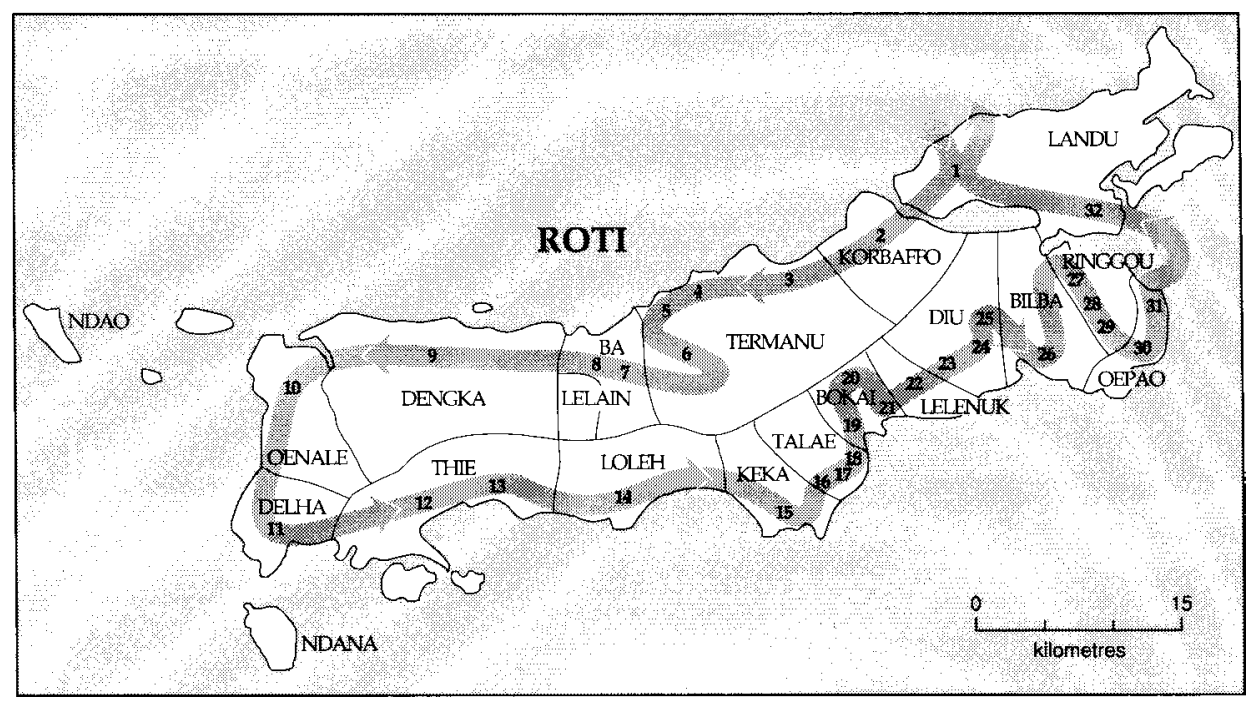

Map 1. The path of rice and millet

Ritual Place Names in the Topogeny of Rice and Millet

\section{Tena Lai ma Mae Oe}

2. Tunga Oli ma Namo Ina

3. Bau Peda Dele ma Kola Sifi Ndai

4. Bako Bau Dale ma Nggoli Kai Tio

5. Ki Lama ma Le Ina

6. Peto Lesi Ama ma Lela Bala Fia

7. Tanga Loi ma Oe Mau

8. Pena Pua ma Maka Lama
17. Longa Fa ma Feo Ne

18. Sosolo Lean ma Batu Tanga

19. Ko Solo ma Nilu Foi

20. Keko Nesu ma Te Alu

21. Medi Daen ma Ndule Oen

22. Lenu Peto ma Safe Solo

23. Diu Dulu ma Kana Langa

24. Pele Pou ma Nggafu Lafa 
9. Dae Mea ma Tete Lifu

10. Nele Dene ma Nada Dano [Ni Le ma Lada Dano]

11. Dela Muli ma Ana Iko

12. Tada Muli ma Lene Kona

13. Tuda Meda ma Do Lasi

14. Ninga Ladi ma Heu Hena

15. Tufa Laba ma Ne'e Feo

16. Pila Sue ma Nggeo Deta
25. Sapan Daen Oe Utuk ma Seun Oen Fi Bolo

26. Feni Fi ma Tane Bau

27. Londa Lusi ma Batu Bela

28. Saba Lai ma Dele Bui

29. Tua Nae ma Lele Beba

30. Fai Fua ma Ledo Sou

31. Lifa Lama ma Lutu Oen

32. Soti Mori ma Bola Tena

Each individual recitation of a topogeny invariably reflects the knowledge and interests of its narrator. The topogeny examined in this paper was told by a narrator, S. Adulanu, from Termanu and it therefore gives greater attention to places within this domain. For other parts of the island, one or another of the ritual names of that domain are invoked to stand for its rice fields. Thus, in effect, the recitation relies on a general knowledge of the ritual names of the domains of Roti.

Map 1 shows the domains of the island of Roti with numbers to mark and identify the ordered sequence of places named in this particular topogeny. Since many of these place names represent domains, the map also shows these domains.

\section{The Creation of Ritual Space}

There exist only two ways of establishing succession - in time or in space. Genealogy functions to establish a succession in time. Topogeny functions to establish a succession in space. Genealogy relies on personal names; topogeny on place names. In both, points of origin and termination are critical. Topogenies have the advantage that they may form cycles by returning to an initial point of departure. Topogenies can be traced, relived, revisited. Genealogy may be more abstract but is often structured in a spatial mode - in Austronesian societies as some form of botanic icon like an immense tree, a clump of bamboo, a twisting vine. And the contours of these icons can be traced. For topogeny, it is the metaphor of the journey that is important. In the ritual chant I have examined, this journey traces the path of rice and millet. The specifics of the journey are part of the revelation of the chant.

The version of this journey of Doli do Lutu comes from Termanu and it is in relation to Termanu that it must be primarily interpreted. From this perspective, it establishes a relationship between Tena Lai ma Mae Oe and the principal rice fields of Termanu. Within Termanu, it establishes a relationship between Bako Bau Dale ma Nggoli Kae Tio, as the premier rice field of the domain, and all other rice fields. It goes beyond this and testifies to the importance of three fields on 
the western side of the domain (of which Bau Dale, Peto and Lela are of great popular, historical significance): Bako Bau Dale ma Nggoli Kae Tio, Ki Lama ma Le Ina and Peto Lesi Ama ma Lela Bala Fia.

For Termanu, the chant creates a ritual space of specific localities. For the rest of the island, it is a recitation of political entities. It produces by way of place names what a genealogy does by means of personal names. Termanu is not the first of the domains, it is the navel and the centre of these domains.

\section{References}

Fox, James J. 1971a A Rotinese dynastic genealogy: structure and event. In T.O. Beidelman (ed.) The translation of culture, pp.37-77. London: Tavistock.

1971b Rotinese ritual language: texts and translations. Palo Alto: Unpublished MS.

1977 Harvest of the palm: ecological change in Eastern Indonesia. Cambridge, MA: Harvard University Press.

1991 The heritage of traditional agriculture in Eastern Indonesia: lexical evidence and the indication of rituals from the outer arc of the Lesser Sundas. In Indo-Pacific Journal 10/Indo-Pacific Prehistory 1990(I):248262. Canberra: Indo-Pacific Prehistory Association. [Also published in J.J. Fox (ed.) The heritage of traditional agriculture among the Western Austronesians, 1992:67-88. Canberra: Department of Anthropology, Research School of Pacific Studies, The Australian National University.

1997 Genealogies of the sun and moon: interpreting the canon of Rotinese ritual chants. In Festschrift for Professor Koentjaraningrat. Jakarta: Asosiasi Antropologi Indonesia.

\section{Notes}

${ }^{1}$ The first version of this chant, which I refer to throughout the paper, was recorded in Termanu during fieldwork in 1965-66. It was given to me by S. Adulanu. At the time I was helped in transcribing and interpreting this chant by P. Malesi, from whom I later recorded a second version in 1977, while involved in filming on the island. The recording of P. Malesi reciting the second version of this topogeny was filmed by Tim Asch. The text of the first chant can be found in Fox (1971b:172-187). 


\section{Chapter 6. Mapping With Metaphor: Cultural topographies in West Timor}

\section{Andrew McWilliam}

\section{Introduction ${ }^{1}$}

I recall having a discussion some years ago with a group of farmers in the mountains of West Timor; a discussion concerning East Timor and their knowledge of that area. During our conversation I was intrigued by an old woman's comment referring to that part of the island as "the head of the land" (pah in a nakan).

This phrase seemed to imply a system of orientation according to parts of the body, and I later confirmed that, indeed, body symbolism for compass direction was a cultural convention in West Timor. In this system the east, which the Timorese call neonsaet (rising day), and the west (neontes, or setting day) may be associated in certain contexts with head (nakan) and foot (haen) respectively. Similarly north and south are referred to by the terms left (li) and right (ne'u). The implication of this referential system is a prostrate human form with arms outstretched and the head oriented to the east.

This system is a generalized one common to all Meto people (atoin Meto), currently the most populous ethnic group in West Timor numbering over 800,000 people. $^{2}$ As a means of directional reference the symbolic use of the body represents one type of cognitive map by which people orient themselves in the world; it forms one of a number of cognitive reference systems by which people situate themselves in the land, accord significance to places in that landscape, and affiliate themselves within complex social and political networks across the territory.

This paper examines two general cultural constructions of place in West Timor. One form has to do with the association of individuals and of groups to particular named places. The second approach reflects a more abstract mode of expressing place through the use of allusion, the spoken image and the rich repertoire of conventional metaphors which Meto people draw upon to inform social discourse.

\section{Named Place}

The most immediate way people refer to place in Timor is through the use of named localities and topographical features. West Timor is mapped conceptually with a bewildering array of named places, each one carrying the record of some 
remembered ancestral deed or experience. The small mountain hamlet in the old political domain of Amanuban, for example, is called Tukfenu meaning "many headless corpses" in reference to some bloody atrocity committed in an earlier era. A ridge in a nearby village has the name Kelonakaf meaning "monkey head", a veiled reference to the camp site of a returning victorious head-hunting party in the early part of this century.

Most named places, however, suggest more peaceful origins. Many carry the affix "oe" as part of the name. Oe is a Meto word meaning water, and places such as Oe Ekam (Pandanus Water), Oe Nunuh (Banyan Water) and Oe Aiyo (Casuarina Water) are clearly named in reference to the critical importance of water sources for settlement sites in this drought-prone region of Indonesia. Still other places are more prosaic in character: Kae (meaning taboo or prohibition), Maunfunu (meaning chicken feather) and Nis Ana (small tooth) are a few examples. Each of these places names a settlement site, known as a kuan, and projects the record of ancestral experience into the contemporary world.

The knowledge of the naming-of-place stories often resides with people who hold particular claims to land and territory in that area. It follows that some places are of greater significance for some people and groups in Timor than for others. Leaving aside the issue of personal history and life experience for now, the focus here is on the collective knowledge of place and territory recorded and maintained by Meto social groups. It is characteristic of these kin-based groups to preserve a highly selective focus on particular named places which are held to be significant markers of their development over time. In part this is the legacy of a centuries-old tradition of shifting agriculture and the continuing search for new arable land. In addition the disruptive effects of political change, pre-twentieth-century warfare and, more recently, rapid population growth have all contributed to the long term dispersal of kin groups across the region, and the creation of hundreds of small hamlet settlements composed of varying numbers of clans or named group segments.

Meto communities record the movements and journeys of their ancestors through a narrative tradition of oral history in which key places in the clans' expansion and segmentation are remembered and retold. In some cases these narrative stories cover the length and breadth of West Timor.

These histories or narrative stories are a vital part of the process of establishing and reaffirming group identity and status in particular claimed territories; a feature which is highlighted in the persistent concern expressed with origins, political alliances and delegated authority over particular named localities and domains.

In these narrative perspectives on the past, a formal style of speaking is employed which is both poetic and semantically opaque in many cases. It differs from ordinary speech (which Meto call uab meto, or indigenous speech) in the 
pervasive tendency to speak in parallelism or synonymously paired sets of phrases. Meto refer to this formal or ritual style of speaking as natoni. It is the language of ceremonial occasion and ritual discourse, and is expressed in a wide range of formal contexts including traditional prayer and formal dispute resolution as well as marriage negotiations and other life-cycle ceremonies.

It is also in this tradition of formal speech that cultural topographies are most highly developed. Knowledgeable speakers are able to draw upon a rich complex of collective representation and metaphor to create enduring images of place, of event, movement and relationship in the landscape. While the knowledge of, and ability to, narrate "histories" tends to be restricted to senior male members of these dispersed kin groupings, the words of these histories are considered to represent shared true knowledge of the past, upon which resides the identity and claims of affiliation of contemporary living members. Among these recurring images which are invoked in "speaking the past" is one metaphor in particular which seems to encompass and define the nature of all Meto histories. This is the idea of the path or, more correctly in ritual speech, the gate and the path (enon ma lanan), which expresses the pervasive collective concern of Meto communities with connected place and the maintenance of continuity with the past. To relate the origins and history of a name group is to narrate its "gate and path".

\section{Agnatic Paths}

Recounting the origins of the clan in West Timor is, perhaps, better described as tracing the path of the name. This is because all individuals in Meto society are affiliated to agnatically-related kin groups called kanaf, a Timorese word meaning name or name group. Thus when a speaker recounts the history of his group he is, in effect, mapping the journey of a name along a spatial and temporal trajectory which is punctuated by significant events or settlement sites (one notion of the gate) along the way.

At the same time the path of the name is also the temporal path of agnation for the named kin group with its ideology of affiliation through fathers to sons. However, this affiliation tends not to be expressed genealogically in the record of particular generations of named ancestors, but rather spatially across the landscape by associating the group's name with specific places and named localities. Genealogical reference to known ancestors in narrative texts is rare. Indeed, often the speaker will refer to the ancestral figures in the first person $(A u)$ thereby wholly identifying himself with an unbroken passage of the kanaf from its origins to contemporary times. To this extent Meto society reflects a preference for what Fox (1992) has described as a topogenic, as opposed to a genealogical, reckoning of affiliation with the past. In other words the reproduction of the group name is measured or recorded in terms of sequential places rather than a sequence of people. 
I have selected elements of one narrative performance to illustrate some of the images of connected place in the path of the name or name group. They represent random episodes extracted from the narrative and by no means exhaust the poetic possibilities encoded in the oral text. Narratives such as these are in many ways only summary accounts which mark events with key verbal references that may represent tangential points for more detailed exegeses. To the extent that many of the images are collective cultural representations and form part of a common oral tradition they are recurrent themes in the histories of all kanaf groups. For this reason a discussion of the particularities of this narrative and its association with a specific group and named territory is unnecessary. Suffice it to say that the narrative belongs to an influential name group in the southern central highlands of West Timor known as Southern Amanuban. The narrative segments are drawn from a longer "history" provided by a senior ritual speaker who performed an account of his "gate and path" to clarify the former political structure of the domain.

\section{Episode I: Origins}

Afi neon unu
ma fai unut ne
Hai Nai antokom bi
fatu Saenam
am oe Saenam.
Bi fatun
tal fatun

Saenam am Oenam

Banam am Onam.

\author{
In the ancient days \\ and the ancient nights \\ our ancestor lived at \\ the rock of Saenam \\ and the water of Saenam. \\ At the rock name \\ the shading rock name \\ Saenam and Oenam \\ Banam and Onam.
}

This segment of ritual speech marks the beginning of the narrative. It is typical of the dispersed kanaf groups of West Timor to associate their mythical origins with one of the numerous prominent limestone outcrops which are scattered throughout the region. For the speaker of this narrative and for the collectivity of his name group, the rock of Saenam represents the ancestral origins of the group. All members of the group refer to themselves in certain formal contexts using the rock name (fatun) of Saenam. Kanaf groups which share common "rock of origin names" are believed to have originated from the same place. It is consistent with the topogenic character of Meto origin journeys that the ancestor in the narrative segment is not named as such. What is marked is the place of origin and the narrative device of merging person with place.

The final couplet of the narrative segment refers to four names. These represent the ritual names of four large, former political domains in central West Timor, namely Miomafo, Molo, Amanuban and Amanatun. ${ }^{3}$ The verbal marking 
of four names is a cultural convention for representing notions of unity and completeness, and is generally associated with aspects of ritual and political alliance. Once again the terms evoke a complementary dualism between people as political communities and places as political domains.

\section{Episode 2: Journey}

$\begin{array}{ll}\text { Es ne naek Atoni } & \text { As a great man } \\ \text { atik paham } & \text { one who kicks the land, and } \\ \text { atik nifu } & \text { one who kicks the water } \\ \text { leuknan } & \text { travelling past } \\ \text { petu ini holain ma } & \text { the slippery bamboo and } \\ \text { noe ini hokan } & \text { the swollen stream } \\ \text { Amsam Noetasi } & \text { Amsam Noetasi } \\ \text { Monam Salbet. } & \text { Monam Salbet. } \\ \text { Kantokombin } & \text { Not staying long } \\ \text { kan nonembin } & \text { not remaining [but] } \\ \text { tipuon } & \text { turning back } \\ \text { nao natuina. } & \text { returning from. } \\ \text { Funam in saen } & \text { The rising moon } \\ \text { am neno in saen. } & \text { and the rising day. } \\ \text { Li'on fain neman } & \text { Bending back one way } \\ \text { tipu'on fain nem. } & \text { turning back the other. }\end{array}$

In this segment the terms pah and nifu from the conventional paired expression for the land, in much the same way that the Indonesian phrase tanah air is used to encompass the land and water resources of the nation. The ancestor of the narrator is identified as one who "kicks the land and water". The conventional Meto meaning of the term natik is to kick, but it is usually associated in ritual language with a capability to expand the territory through force and particularly through head-hunting. The idea that the ancestor is a head-hunter is supported in the following couplet by the obscure reference to "the slippery bamboo and swollen stream". This phrase represents a mnemonic or marker which can form the basis for further explication. It is associated in this case with the story of how the ancestor obtained the ritual power to become a feared head-hunter and gained what is termed the kan le'u or the sacred, awe-inspiring name of the group, which is used to this day. ${ }^{4}$ Given that it is not permissible to speak of the original name of the kin group, this form of phrasing may also serve to mask an event which should not be spoken of directly.

Finally the evocative image of li'on and tipu'on neatly expresses the process of a group wandering across the land in search of a place to settle. The terms 
refer to weaving techniques: $l i$ 'on is a method of bending a plait back in on itself, and tipu'on has a similar meaning except the woven strip is snapped back and secured. The verbal image therefore expresses a movement somewhat akin to an S-shape; a wandering without security of tenure.

\section{Episode 3: The gate of Tumbesi}

Tiaman tok, nak

pah $i$ suis leuf

am ma'len leuf.

Mas, of tahat kalekofa

ma tinut kalekofa.

mautum, hit nao neo

toi manuan am

eno manuan es ne

fatu Tumbesi ma

hau Tumbesi.
Reaching there, saying

this land is very thin

and very confined.

Later [we] will eat poorly

and drink poorly.

So be it, we will go to

the wide stile and

the wide gate that is

the rock of Tumbesi and

the tree of Tumbesi.

This third example expresses several important collective representations of place and topography. Ma'lenat (meaning confined or narrow) and manuan (wide and expansive) are concepts frequently associated with motivations to shift to new settlement areas. When areas become overpopulated and garden land is in short supply, disputes and fighting among neighbours and relatives increase, and the land is said to become narrow (ma'lenat). One strategy to overcome this situation is to move to less populated forest areas and to establish new settlements. These thinly populated frontier areas are said to be wide or broad (manuan). The historical movement of Meto populations from the narrow confined lands in the eastern mountains to the wide open country in the west represents a continuing feature of Meto society. Present day population pressures and environmental degradation has, if anything, increased this trend.

In the segment above, the pairing of eno and toi as the "wide gate" and "wide

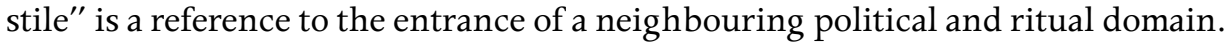
Today the conventional meaning of eno is simply a door or doorway. However, in the above sense the ritual meaning of eno has mostly to do with the main gateway or boundary entrance to a different political community. One typical feature of Meto political structures was the appointment of warrior groups known as meo (cat) to guard the conceptual "gates" of the domain from incursions by enemy groups (see McWilliam 1996). In this case, the "wide gate" refers to the domain of Amanuban because it is associated with the former ruling centre of the polity, Tumbesi. In the past Amanuban was a large and sprawling domain which, in part due to its size, was frequently torn by internal unrest and feuding. 
In associating Tumbesi with the "rock" and the "tree", the narrative description identifies the named place as a ritual and sacrificial centre. In traditional Meto religion, the pairing of "rock" and "tree" explicitly refers to sacrificial altars which took the form of large trees with stone altars secured at the base, or forked wooden posts in which altar stones were secured. These sacrificial sites were foci for rain-making and for harvest ceremonies associated with agriculture and the complex of rituals related to name-group life-cycle ceremonies and to head-hunting cults. One shorthand term for Meto religion was hau le'u faut le'u, which may be glossed as "the sacred tree and sacred rock or stone" (see McWilliam 1991).

The special importance of Tumbesi here is that it establishes a political connection between the kanaf group of the narrative and the old ruling centre of Amanuban, which represents the source of its subsequent claims on territory within the domain. The remaining episodes in the narrative relate this process of establishing claim and securing political allies in the southern part of Amanuban.

\section{Episode 4: The ordering of people and place}

Aet pilun u fani
ma aet so'it ma solo
onat futun suan
bi neo lana Teas ini
na panat Teas
onan apao
hue sufan
usaip sufan
bi nepo kotin
ma nenu kotin.

Take the head wrap and axe and take the hair comb and silver coin to tie in the roof spar at the path of Teas the platform of Teas to become the guardians [of] the flowers of the hue tree the flowers of the usaip tree at the outside fence and the outside boundary.

This final illustrative segment is chosen arbitrarily from the oral testimony as an example of the way allies of the narrative-owning group are placed within the territory. Just as the ancestors of the speaker are said to have been directed to settle an area by the ruling centre of Amanuban, a settlement they achieve by "spearing the wild birds and feral chickens and evicting them from the land", so the ordering of allies within the territory is represented as a form of directing and delegating (malek anmalul) subsidiary groups to defensive places within the new political territory. By this process an order of social and political precedence is established whereby rights to settlement areas and land devolve through the direction or permission of more central, higher-order authorities. In this way claims on land and place may be said to be "nested" in the prior rights of more senior groups. 
There are three aspects of the above segment which highlight specific Meto cultural notions of place. The first five lines are references to settlement and the implied establishment of food gardens in the area known as Teas, presently a formally constituted village in south central Timor. Second, this place is located at the periphery, the "outside fence and boundary" of the domain in relation to the central position occupied by the narrator's ancestors. To this extent the narrative reflects a typical Meto conception of politico-ritual order whereby the centre or "navel" of the domain exerts authority outwards at a diminishing rate until, at some point on the periphery, a rival centre exerts a stronger attraction. In the turbulent period of the nineteenth and early twentieth centuries in particular, the prevalence of predatory raiding and head-hunting by rival political communities required the positioning of strong defensive outposts.

Third, there is an otherwise obscure reference to the hue and usaip trees. The meaning of this couplet is related to the harvesting of wild honey beehives (oni naus) and the bees' wax they contain. Formerly in Timor bees' wax provided a lucrative export commodity supplying the flourishing Javanese batik industry, particularly in the nineteenth century. Often these wild hives were located in the forested buffer zones which separated competing political interests. In the narrative the ally is sent to guard this economic resource and in return for rights to settle and cultivate the surrounding land, it would offer up the harvested bees' wax as tribute to the centrally located ruling group. ${ }^{5}$ Though semantically condensed this episode provides a fine example of the poetic construction of place in the context of a political order.

The narrative performance from which these episodes are drawn does not end in the present day. Rather it culminates in an unspecified time in the past when the name group had secured a position of relative autonomy and independence within its new territory and had claimed the political title of Lord of the Land (Pah tuaf). Since that time new hamlets have evolved and segmented in the continuing dispersal of groups across the region, creating further minor extensions to this primary path of the kanaf group name. Reference to the central narrative is made by orientation to what is termed "the old settlement and the old place" (kuamnasi ma balemnasi) where the ancestral name resided in the past and where today small groups of old people linger on, preserving the links to the past and guarding ancestral heirlooms and graves.

Among contemporary groups that identify with the particular narrative discussed above and the record it preserves, the legacy of the narrative past is an enduring one in at least two important ways. First, the oral testimony is a measure of the name-group identity linking a name with the significant places and relationships along its journey of origin. Second, it serves as a legitimizing discourse and statement of claim to the land which it occupies and accepts as an inherited right. 


\section{Affinal Paths}

In recounting the narrative path of the name group, mention is sometimes made of political alliances founded on the basis of marriage exchange. It is unusual, however, for specific affinal ties to be mentioned in the context of narrative history. Yet the very existence and reproduction of the exogamously constituted name group is dependent upon the flow of life which derives from women, as wives and mothers, who marry into the name group from outside. This is a cultural imperative in Meto society, and one also represented through such conventional metaphors as a path (lanan). The path of alliance is symbolic of the fertility that one name group passes to another. It encodes the polysemic image of the trodden path that links affines across space and between place as it intersects the path of agnation and enables it to continue. This is why wife-giving affines are referred to as "mother and father givers of life" (en amahonit ma am amahonit).

A starting point for appreciating the nature of affinal paths in Meto collective representation is the perspective from the house and hamlet. The conical thatched house (ume kbubu') and the cluster of nucleated households which constitute the hamlet (kuan) represent the primary level of socialized space in Meto society - a domesticated centre where most social life is conducted and negotiated (see Fox 1993).

The orientation of the Meto house is based on a three-level, concentric model of ordered space. The house itself is central and referred to as inside (nanan). This is a classifactory female space associated with food storage and preparation as well as with sleeping and childbirth. In contrast the area immediately outside the front door is termed mone, the word also used for "male" or "masculine". While Meto do not make this association explicit the conceptual link of male/outside and female/inside is strongly implied. One Meto aphorism for example holds that a woman's role is to guard the house and its contents (bife apanat poni), while a man's role is to seek income and wealth outside (atoni naim noni).

Beyond the houseyard, or more specifically beyond the sturdy fence which typically marks the houseyard boundary, everything is termed kotin, meaning "outside" (or literally "behind", connoting that it is out of sight). The realm of the outside (kotin) is symbolically associated with the unknown, with strangers, enemies and spirit entities.

These conceptual markers of place or space are also relative terms for delineating degrees of inclusion and exclusion. The house, for instance, may be conceptually inside (nanan) in relation to the hamlet, while in a different context, the whole hamlet may be nanan in relation to the wider world of village and political domain. The contrast implies a distinction between the ordered, familiar, domestic sphere of the inside - conceptually a female place - and the uncertain, 
untamed and potentially dangerous realm of the outside - conceptually a male space.

One example of how this conceptual order is realized in practice is seen in the way Meto deal with what has been termed bad death (see Hertz 1960; Fox 1973). All violent, unexpected and sudden deaths are considered ritually threatening and are treated as "outside (or male) deaths" (maet mone) by Meto communities. Such instances should be treated in ritually prescribed ways to render them spiritually harmless. These deaths are distinguished from the relatively benign deaths of the "inside" (maet nanan) as a result of expected or at least not inexplicable deaths.

The same focus on categories of inside and outside are also invoked in the cultural representations of marriage exchange and alliance. In Meto kin terminology the classification of matrilateral and patrilateral cross cousins is termed the wife path (fe lanan) and the husband or male path (moen lanan). These are clearly favoured marriage unions and when occurring may be described as "marriages within the house" (matsao/nakaib ambi ume nanan). Alternatively they are described as marriages which "strengthen the roof of the house" (na li suaf am takpani, where suaf refers to a roof spar, and takpani are the forest vine ties which encircle and secure the spars). In other words the metaphor of the path which characterizes the joining of separate groups in marriage is transformed into the metaphor of the house when such alliances are reaffirmed through subsequent cross-cousin marriage. Affines may then be said to live in one house, or under one roof, with all the mutual ties of obligation and reciprocity that this implies.

In contrast, marriages which are negotiated between groups without affinal links are referred to as "from the outside" (nako kotin) or alternatively "from a different rock" (nako fatu es, or rock of origin). Because of the social and sometimes geographical distance involved marriage negotiations in these cases are more protracted and usually involve more substantial marriage gifts. These types of marriage are described in the following segment of ritual speech in which the prospective groom is said to

laka noe

ma sae bahan

on a ma'fe bi mata teme

am ma'fe ila teme. cross the river

and climb the fence

for a stranger eyed wife

and a stranger faced wife.

The images here are typically Meto and express important cultural notions about the transformation of strangers (and by inference, enemies) into affines through the connecting of place by paths of alliance. The phrase lak noe (to cross the river) is frequently used to represent social and geographical distance. Rivers 
are often boundaries between political domains and territories, and while contemporary economic and political change has led to the weakening of the former insularity of social life, most Meto farmers are reluctant to marry outside older established patterns of social networks. The second image of "climbing the fence" is partly an allusion to one of the stages in the ceremonial process of marriage termed "to climb the stile and descend the steps" (sae toi ma sanu se'at), which refers to the proper etiquette of marriage negotiation, where one formally enters by the front gateway to the houseyard in the "light of day" (neno pupu), as opposed to marriage by ritual abduction (mnaenat) where one is said to "go stealing women in the night" (nao nok fai ma nabak bife). In the third image the term teme, which I have translated as "stranger", literally means "round". The image of one being round eyed and round faced portrays the expression of shock and surprise at seeing outsiders.

The joining together of potential affines in marital alliance is expressed in the formal process of marriage negotiation where, typically, a senior arbitrator is appointed to facilitate the union of marrying groups. He is referred to as the nete lanan, literally the "bridge path", and he provides the role of "smoothing the path" in the sometimes delicate negotiation of the terms of the marriage exchange. The complementary notion of the gate is epitomized at the main marriage exchange ceremony when the wife-takers mass at the front of the bride's houseyard and request the opening of a ceremonial cloth gate (klibat klabat), which is erected to block the path. This is the first of three cloth barriers which are erected to shield the bride from the groom. Ceremonial exchanges to open (nasoetan) the remaining gates at the house proper and across the entrance to the room where the bride waits are both accompanied by ritual dialogue and the offering of prestations. This appropriation of the wife-mother sets in train a life-long process of gift giving and the provision of labour services to acknowledge the gift of life and to keep the "path of alliance" open.

The path created by marriage is also the pre-eminent symbol of continuing alliance, and the sum of affinal relations which are recognized by any one Meto house or name-group segment is the total number of active "paths" (lanan) which radiate out in the form of married sisters and daughters of the name group. The image is a compelling one which is continually reinforced and reaffirmed through the conduct of important ceremonial and ritual contexts when the various wife-taking affinal groups are called upon to fulfil their obligations to the life-giving house and kanaf group. So, for instance, in times of death, the family is said to "send out the feet" (tapoitan haef) in the form of younger men who go to inform the various affinal "paths" of the kanaf group of the death. This engages the obligations of the wife-taking houses who come to grieve and deliver gifts of meat and rice. In so doing they fulfil the cultural expectation that a wife-taker should not arrive at his wife-giver's house with "empty shoulder and empty hand" (kan ben lumaf ma kanim lumaf). 
At the same time the knowledge of affinal paths fades with time. This is in part the consequence of not renewing earlier alliances with subsequent marriage exchanges. It is also probably a consequence of the importance accorded a patrifilial ideology whereby the path of the name has a permanent enduring quality at once stable and immutable over time, though ultimately sterile because it may not procreate with its sisters and daughters. This path is intersected by and contrasted to the mutable and numerous more ephemeral affinal paths which, having transferred the gift of fertility and life from one name-group to another, may lapse and be forgotten unless renewed or kept open by subsequent marriage exchange. ${ }^{6}$ In these intertwined spatial images of process and relation the metaphorical mapping of social paths across the landscape provides a cultural reflection of the mountains of Timor with its networks of narrow footpaths that link hamlet to hamlet, people with place, and the major gateways which tie larger ritual and political domains to one another.

\section{References}

Fox, James J.

1973 On bad death and the left hand: a study of Rotinese symbolic inversions. In R. Needham (ed.) Right and left: essays on dual classification, pp.342368. Chicago: The University of Chicago Press.

1992 Genealogy and topogeny: towards an ethnography of Rotinese ritual place names. Paper presented at the annual Australian Anthropological Society Conference, 1992, Canberra.

1993 Memories of ridge-poles and cross-beams: the categorical foundations of a Rotinese cultural design. In J.J. Fox (ed.) Inside Austronesian houses: perspectives on domestic designs for living, pp.140-179. Canberra: Department of Anthropology, Research School of Pacific Studies, The Australian National University.

Hertz, R.

1960 Death and the right hand. London: Cohen and West.

McWilliam, Andrew

1991 Prayers of the sacred tree and stone: aspects of invocation in West Timor. Canberra Anthropology 14(2):49-59.

1996 Severed heads that germinate the state: history, politics and headhunting in Southwest Timor. In J. Hoskins (ed.) Headhunting and the social imagination in Southeast Asia, pp.127-166. Stanford: Stanford University Press.

Middlekoop, $\mathrm{P}$. 
1960 Curse retribution and enmity, as data in natural religion, especially in Timor confronted with the scripture. PhD thesis, University of Utrecht. Traube, Elizabeth

1986 Cosmology and social life: ritual exchange among the Mambai of East Timor. Chicago: University of Chicago Press.

\section{Notes}

1 A version of this paper was presented at the annual Australian Anthropological Society Conference in Canberra, 1992.

2 This ethnic group is referred to variously in the literature as the Atoni, Atoni Pah Meto, Dawan or simply Timorese. I prefer the term Meto, which has the meaning of indigenous and is usually contrasted to the term kase meaning foreign. Hence the common phrase Hai atoin Meto (we Meto people) as opposed to atoin kase (foreigners or all other non-Meto people). The term atoin is the metathesized form of the word atoni.

3 The names of each of these political or territorial entities in turn can be expressed more completely in ritual language. The formal term for Amanuban, for example, is Banam or rather Bunuh bi teno nenu Banam, which is itself a kind of exegetical code alluding to the mythical origins of the domain.

4 Middelkoop (1960) provides a useful discussion of the nature of the $l e^{\prime} u$ complex in Timor.

5 It was symbolically appropriate that the ruling centre in this context was said to receive the white wax head (oni in a nakan) as tribute from its allies. Metaphorically the ruler was the "head" (nakaf) of the political body in much the same way as the concept is used in Western political expressions. As such the ruler received "head" portions of commodities as tribute, including the noni nakan or "head money" received for the sale of sandalwood, and the "heads" of maize and rice as harvest tribute not to mention the severed and smoked heads of human enemies.

6 A similar idea is expressed by Traube about the Mambai of East Timor whose culture has many parallels with the Meto in the west (see Traube 1986:96). 



\section{Chapter 7. Knowing Your Place: Representing relations of precedence and origin on the Buru landscape}

\section{Barbara Dix Grimes}

People on Buru use several strategies to refer to geographical features on the landscape of their island. As on other eastern Indonesian islands, certain places are designated anthropomorphic metaphors, conceptualizing the island as a body. On Buru the large bay in the east (Kayeli Bay) is the "face" of the island. The range of mountains running east-west just to the south of the lake is called the "backbone of Buru island". Kak Pala Madat, the tallest mountain, towering $2,735 \mathrm{~m}$ high in the north-west of the island, is a "knee".

Another strategy is to name places after some characteristic feature. Two days' walk inland from the town of Leksula on the south coast is the village of Fakal where my husband and I first lived on Buru. Fakal, we soon found out, was the name of a large tree located near the village. A place in the jungle we often walked through was appropriately called fraga lale ("millipede centre"). ${ }^{1}$ We were told stories about a former village simply called Kabut ("mud"). Other Buru places are known in reference to significant events which occurred on those spots, such as a previous village named Ehu Molo ("Ehu Drowned") where a man named Ehu drowned, or a spot in the jungle that has come to be known as Geba Rohin ("People Bones") where burnt human bones were discovered after a murder. Places are also referred to in terms of land use, such as "Fallow Garden of Individual So-and-So". If people migrating to a different place on the island have not moved far, they may keep the same village name and some places thus come to be known as the location of "Old Village Such-and-Such".

The rivers and many streams on the island are all named and are culturally significant features of Buru geography. Many villages are named after nearby rivers or springs, such as Wae Katin ("Pandanus Water"), Wae Reman ("Long Water"), and Wae Haa Olon ("Headwaters of Loud Water"). Rana ("lake") is the name used to refer to the lake in the centre of the island as well as to several named villages surrounding the lake. Because this general area around the lake is as far "upstream" as one can go on the island, Rana is also a metonym for the interior of the island, symbolizing the cultural value of upstream over downstream, of the mountains over the coast.

In addition to being named and assigned value in these ways, places are also evoked in defining certain social relations. My purpose here is to explicate how these Buru places and relations come to "stand for" each other. Two sets of 
relation will be of significance. One relation is metaphorically mapped from the imagery of a plant where the "trunk and roots" (lahin) stand in contrast to the "leaf tips" (luken). This botanical model provides a conceptual model for causation in that roots are considered to be origins, sources and causes, while tips are consequences, results and effects. This model also structures Buru notions about life and prosperity as growth which proceeds from "roots" to "leaf tips". The second relation is constructed through another set of binary categories used to establish an order of precedence or seniority: the terms "elder" (kai) and "younger" (wai). As with the root-tip relation, temporal sequencing is a crucial element in the construction of this relation, for both roots and seniors precede tips and juniors. However, there is also a significant difference in that tips come from roots, but juniors do not come from seniors. Things categorized as senior and junior are conceived of in varying ways as units with some kind of commonality (like a common origin), but because one unit is differentiated as being prior and the other as subsequent the two units are distinct. But, again like the trunk-tip relation, the elder-younger relation is also asymmetrical in that an inherent inequality is built into the relation. Buru people overtly express that seniors are always superior to juniors and they repeatedly remind juniors "not to forget" they are juniors and to treat their seniors with respect. When the two categories elder-younger are applied recursively to multiple units, a hierarchy of precedence is created with internal relations depending on a given, individual position within the hierarchy (see Figure 1). All those elder must be respected, all those younger must show respect.

\begin{tabular}{|c|c|c|c|c|c|c|c|c|}
\hline elder & $>$ & \multicolumn{2}{|c|}{$\begin{array}{l}\text { younger/ } \\
\text { elder > }\end{array}$} & $\begin{array}{l}\text { younger/ } \\
\text { elder }\end{array}$ & $>$ & \multicolumn{2}{|c|}{$\begin{array}{l}\text { younger/ } \\
\text { elder }>\end{array}$} & $\begin{array}{l}\text { younger/ } \\
\text { elder }\end{array}$ \\
\hline
\end{tabular}

Figure 1. A hierarchy of precedence (from Fox 1989:52)

These two relations then are the relation of origin (cause and effect), expressed through the metaphor of "trunk" and "tip", and the relation of precedence expressed through "elder" and "younger". Two different kinds of places are culturally constructed with these relations on Buru: "origin places" and "taboo places".

\section{Origin Places}

In using the phrase "origin place" the relation of origin is immediately obvious, but to understand what this means it is necessary to refer to Buru kin groups called noro. A noro is the highest level political structure in Buru society, as well as being the exogamous unit. Internally a noro can be composed of a varying number of lower level units called "house-circles" (hum lolin). Both these groups 
are conceived of as bounded units in which individuals are socially located at birth. Social movement occurs at marriage when women "cross the threshold" (suba), leaving their natal noro, to "enter" (rogo) the noro of their husband. Because sisters leave while brothers "stay" (defo) and their wives enter, the permanency of the noro is defined by the males who remain in it for life.

In the discourse of inter-ethnic relations on the island, people who belong to these noro consider themselves "original" or "indigenous" to the island, using the term orang Buru asli in the Ambonese Malay lingua franca or in Indonesian. The rhetoric differentiates around 43,000 orang Buru asli from over 60,000 immigrants who have settled on the coast of Buru maintaining their diverse cultural and linguistic traditions. Some of these immigrant groups have arrived recently, others have been on the island for several centuries. Here my focus is on the minority native population, the so-called orang Buru asli, whose traditions have historically had the longest contact with the island. Today these people live both on the coast and in the mountainous interior of the island. They are socially divided into around 35 noro of varying sizes and speak an Austronesian language which they refer to as "the voice/speech of Buru island" (li fuk Buru), or in Indonesian, Bahasa Buru. ${ }^{2}$ On the coast there has been a history of contact with Islam since the days of the Sultanate of Ternate in the sixteenth century. Consequently, some of the native Buru people who live on the coast, as well as many of the immigrants, are Moslem. There has also been a history of contact with Christianity in the general region since the sixteenth century when the first Europeans arrived. However, Buru island was of little significance to either the Portuguese or Dutch traders, and contact with Europeans remained minimal. Around the turn of the twentieth century, relatively late in the colonial period, Dutch missionaries went to Buru. Subsequently Christianity has been adopted by various segments of the native population living both on the coast and in the interior of the island. In the discourse of ethnicity, however, these internal religious differences among the native population are not at issue. There the primary criterion is belonging to a Buru noro.

In defining itself in this way, the native Buru population can appear to be a unitary whole in contrast to the non-native immigrants on the island. However, any totalizing cohesiveness is found only in discourse, for there is no centralized political or ritual system unifying the different noro on the island. Buru people themselves describe their situation as one in which "each noro governs its own noro" (noro saa perinta tu nake noro). As a whole, their society is defined by networks of inter-noro relationships which can be characterized as much by alliance and marriage as by hostility and fighting. But regardless of whether two noro are momentarily focused on exchanging women in marriage or fighting each other in warfare, the relationship is predicated on a continual striving for symmetry, for the Buru ideology of inter-noro relations is "a person replaces a person" (geba gati geba). 
This principle applies equally to the loss of women in marriage as it does to the loss of men in warfare. When a noro loses a woman as a bride to another noro, she must be replaced although there are several ways this requirement can be fulfilled. One option is to replace her immediately with an incoming woman from her husband's noro. This occurs when the two noro agree that a marriage should involve "exchanged maidens" (emhuka eptukar). A second option for replacing a bride is to "return a child" (anat saa oli), by giving one of her own children back to her natal noro "to replace its mother" (gati nak ina). Finally, a bride could be replaced by bridewealth, giving her natal noro the potential to "pay for" (sili) an incoming bride at a later date. Similarly, when a noro loses a member at the hands of someone in another noro through murder or manslaughter, that loss must also be "paid for". "Revenge killing" (kalungan) is a legitimate way to reciprocate the loss and is only complete when there are an equal number of deaths in each noro. Alternatively, the bereft noro may decide to "make peace" (puna damen) and request that a child from the offending noro be given to them to "pay for the blood" (sili rahan). So in both warfare and marriage, relations between two noro are settled only when losses have been compensated. The underlying potential for equality exists in inter-noro relations because there is no system of "generalized exchange" nor any other system permanently ranking noro in fixed asymmetric relations. Furthermore, when the loss of a noro member produces an asymmetric relation between two noro because of an outstanding debt of a life, compensation restores the equilibrium of inter-noro relations.

In contrast to these relations there are other Buru relations which are permanently asymmetric. Such relations are found within a noro where "elder" and "younger" categories of precedence apply at various levels, creating internal hierarchies. These terms rank same-sex, same-generation kin within a house-circle; co-wives of the same husband; husband and wife; and the various house-circles within a noro. As social groups, the house-circles are assigned precedence on the basis of origin narratives which relate the timing of their relative establishment. Because the first settlement, the first house-circle, of a particular noro is considered to have been at the headwaters of a stream, the ranking of house-circles tends to be geographically objectified along the river. Elder house-circles were established before and upstream to younger house-circles established later and downstream. An ordering of precedence thus flows from elder to younger, from upstream to downstream, from the headwaters in the mountains at the centre of the island to the periphery of the island at the coast.

When an older couple came to visit their married daughter, I was informed by people in our village that the husband was the eldest male sibling of the eldest house-circle of the Gewagit noro. Actually it was his own Gewagit kinsmen who repeatedly stressed the man's precedence within his house-circle and the precedence of his house-circle within their noro. "There is no one elder than 
him", they told me. "He is 'on top' (ringe fi saka), all others 'descend seaward, descend seaward' (toho lawe, toho lawe)." As I enquired I found that his significance to his kinsmen was based exclusively on his structural position of elderliness. He was not a "titled" leader, not a great warrior, nor any kind of ritual specialist, for on Buru these social positions are neither hereditary nor based on primogeniture. The reason for the respect shown this man by his kinsmen was simply and sufficiently because he was the eldest of the eldest. By telling me and reminding everyone that he was the most "upstream" of all Gewagit males, they were in fact "not forgetting" his seniority and precedence, a precedence objectified along the river system.

Summarizing the nature of external and internal noro relations, it could be said that external noro relations are based on a very careful "bookkeeping system" for keeping track of lives lost, while internal noro relations are based on an equally careful "precedence system" for keeping track of who is elder and who is younger. Yet Buru noro are more than just a means of keeping track of people. A noro gives people more than just a name, it provides an ideology as well. In considering how Buru people portray their social world, the noro is central because the Buru rarely present an image of a unified Buru society. Rather, they talk very frequently about their particular noro, the importance of their noro, the uniqueness of their noro, the past glories of their noro. In a certain sense, their social world is their noro. Such noro-centric discourse resembles what Ricoeur (1986) has called a social imaginaire, referring to the discourses by which a society provides itself with an ideological stability and identity through representing or recollecting its "foundational symbols" (Kearney 1989:21-22). In all the Buru discourse about noro there are in fact several foundational symbols which people continually use in recollecting who they are. These symbols are concerned with origins, for noro are like "origin groups" in other eastern Indonesian societies:

[W] hat they claim to share and to celebrate is some form of common derivation. This derivation is socially constructed and may be variously based on the acknowledgment of a common ancestor, a common cult, a common name or set of names, a common place of derivation, and/or a share in a common collection of sacred artefacts (Fox 1990:3).

One of the most significant foundational symbols of a noro is its founder. While the present-day members of a noro are conceived of as descendants or "tips" from its founder, this does not mean founders are human ancestors, for in Buru cosmology they are distinct from and superior to humans. ${ }^{3}$ In the distant past, during the founding times of society, these founders were visible but are no longer so. Each founder is unique with a unique name, all of which contributes to the uniqueness of each noro. Some of the founders are female, some male. Some were autochthons who miraculously "appeared" on the island, while others 
are said to have come to Buru by boat. But regardless of whether they just appeared out of nowhere or arrived from elsewhere, each founder is associated with a unique river or stream on the island - a "founder stream". Beside this stream there is a further place of importance called the "place of the planted [house] pole" (tean elen). For autochthonous noro, the "place of the house pole" is at the spring in the mountains where the founder is said to have appeared. For non-autochthonous noro it is the place where the founder established him/herself after arriving on the island, at the headwaters of the stream or river the founder walked to after leaving the boat, often where the founder was given land by autochthons. In addition to the stream and the place of the house pole, the location of the founder's "boat disembarkation place" (waga enohon elen) and the name of the boat are also important foundational symbols for non-autochthonous noro.

Today many noro have a ritual house (near their "place of the house pole") in which various heirlooms belonging to the noro are stored. Typically these include ruling cloths and other objects of noro history, and contrast with bridewealth objects which belong to specific house-circles and can be given away to other noro in a marriage transaction. Bridewealth objects - like sisters - circulate, while these noro heirlooms - like brothers - stay in the noro. The significance of this ritual house, however, is not merely as a place for storing antiques. Through these structures people's places of origin and their connectedness to the island are made visible.

It is through this discourse of place that people construct the difference between natives and immigrants, between the "people of Buru island" (geb fuk Bururo), the so-called orang Buru asli, and "people from across the sea" (geb fi lawe). In certain regards, the kin groups of immigrants from nearby islands look structurally and functionally like Buru noro. Nevertheless, they cannot be Buru noro; their members cannot be "people of Buru island" because they have no connection to a founder's "stream" or "planted house pole place" on Buru. 4

This discourse about place can be considered a noro's sacred foundational narrative. Knowledge about a noro founder, the stream, the place of the "planted house pole", the boat name and the place of the boat disembarkation is in fact held with great reverence. Only noro members have the right to "open" the "story" (endohin) about their origins and they must always take care to "hide" (foni) the story. After wondering when some of these wonderful stories would be "opened" to me, I came to realize that in fact I had already heard many of them many times, only they had not come in the form I was expecting. These "hidden" stories turned out to be neither secret nor sophisticated; they were simply the names and the places concerning each noro's origins. In reality, many people know the sacred names and places of other noro. From a Western perspective, the stories can hardly be said to be "hidden". And yet from a Buru 
perspective where the primary purpose of hiding anything is to protect it from loss, each noro does indeed keep its sacred origin story well hidden.

In comparison to the eloquent poetry of lengthy origin narratives in other eastern Indonesian societies, the paucity of these Buru origin stories is striking, yet these very features reflect a consistency with other Buru values. Valeri (1990) has noted that in contradiction to certain anthropological generalizations, for the Huaulu on the island of Seram near Buru, "elaboration is not considered as more valuable than simplicity". In contrast to the wordiness and powerlessness of the present and of less important kinds of Huaulu knowledge, the simplicity of knowledge from the mythical past is proof of its superiority. This notion is reflected on Buru as well. Furthermore, it is in public situations, in formal speeches, that people attempt (and are expected) to be eloquent and profuse. Buru origin narratives are not elaborate, nor are they meant for public performances. They are meant to be hidden, preserving the simple and sacred knowledge of the distant past.

These narratives are more thorough than just revelations of the past; they are also scripts for contemporary action. In times of difficulty individuals can "return" to their origin place to pray (esmake) and request blessing from their founder. The men who "guard" the origin place of the Mual noro in a village near the Wae Brapa River, ${ }^{5}$ told me of two recent cases where kinsmen had come to their village seeking blessing from their founder. In one case, a blind Moslem Mual man had come across the sea from Ambon, walked with assistance for four days up treacherous mountain trails to get to the origin place where he made a sacrifice of money to the Mual founder, requesting to be cured of his blindness. In the second case a Christian Mual man living on the coast of Buru went back to the origin place to seek blessing from the Mual founder because of a labour contract in which he was building a government airstrip. The rare bit of flat land on the coast where various outsiders and government officials had proposed to build this airstrip happened to be the "boat disembarkation place" of the founder of the Mual noro. When work on the airstrip repeatedly failed, this man went back to seek the blessing of his noro founder, so the project would succeed.

This means that these places not only represent past origins, they also represent present sources of life and blessing. This is clearly reflected again in an earlier description by the Dutch missionary, Schut (1918:127), who referred to Wae Brapa as a small river in the interior of the island where one found the "consecration place" (gewijde plaats) of the "Mual clan" (Moeal-stam). Although those are Schut's terms, not mine, they clearly reflect what Wae Brapa signifies. In a description of Buru marriage, Schut (1918:125-140) also recorded a formal speech given by a Mual elder at the time a Mual "maiden" was to leave her natal 
home as a bride. The speech began with praise for the life that flows from Wae Brapa: 6

Barkate, Wae Brapa!

Da ba ila filim dae,

da ba pola filim dae;

tu nak mokin di leluke,

tu nak bawa omon gilate;

nak kawaan lahin sin le-leret,

lahin tane eflawa.

Nangan lawe pa man laut

nangan lawe pa man olat

olat da ba emngesa tuha

laut da ba emngesa tuha.
Blessed Wae Brapa!

Flowing from upstream,

bursting forth upstream;

with its fine-branched mokin,

with its shiny bawa leaves;

its tall bamboo,

and radiant trees.

Its opening downstream flows to the ocean, its opening downstream flows to the sea; the sea becomes one with it, the ocean becomes one with it.

But it is not only botanical life that flourishes because of Wae Brapa, the life of those in the Mual noro does as well. Remembering that the young bride would be taken to an unfamiliar place, Schut (1918:129) comments on the elder's speech:

The meaning is this: The young girl is departing from the Wae Brapa River where she was born. This water is sacred to her. If she becomes ill at her new residence, they must bring her back to the Wae Brapa River so that she can be given this water to drink, and so she can be bathed in this water [my translation].

For individuals of the Mual noro, Wae Brapa objectifies their relation to their origins, to their source of life and success. Wae Brapa is a place on the landscape, a stream in the mountains of Buru, but it is also a "foundational symbol". It is the place that people of the Mual noro celebrate when recollecting who they are.

From narratives about place, people of a given noro also construct their connection to a well-defined territory surrounding their place of origin. This territory is divided with each house-circle having responsibility for a given portion. As "masters of the place" (geba neten duan), other people must come to them to request permission to make gardens or to hunt there. Today there is a far from perfect correlation between places of residence and places of origin because people frequently migrate to other parts of the island. When undesirable consequences occur, such as the many deaths of a "big dying" (enmatan haat), people see it as essential to "drop the bad place" (tatak neten boho) and move on to a different place. But even if people have migrated and do not live on their land, they still inherit it by virtue of belonging to their house-circle and they still control rights over its use. And they may - even after spending several generations away - eventually return to live there. 
It is in the context of these migrations that Buru people reconstruct the more recent past with narratives tracing their forefathers' footsteps across the landscape. This tracing is very complex and individualized, for people of a single noro or even a single house-circle do not all live in the same place. Furthermore, when villages are abandoned, the people do not always move as a cohesive group. Bad inter-personal relations within a village are often the motivation for a migration or the perceived cause for a "big death" precipitating a migration. So a village often splits up, some households going in one direction, some in another. The following is a translation of a story about the migrations of her family told to me by a woman approximately sixty years old. I estimate the time depth to be eighty to one hundred years at most.

Our grandfather lived at Wae Brapa. There people of the Mual [noro] and the Gebhain [noro] married each other and they "entered religion". After a "big dying", they split up. Some went to Wae Katin, some to Wae Sam Belen. At Wae Sam Belen there was a "big dying"; they moved sideways to Ehu Molo. That was the time of the elder brother of [a man I knew]. People paid [Dutch] taxes then. An Ambonese pastor was at Ehu Molo. They built a GPM church, ${ }^{7}$ but people started dying and the pastor left. [A man who came to be a leader in the SJA church ${ }^{8}$ ] started going there, but because so many died, people moved on to Wae Bunan. At Wae Bunan there was no church, but SJA services were held in the house of [another man's] mother's brother. Then people moved on to Negriatlale. Three times they built SJA church buildings there but then there was a big dying. ${ }^{9}$ People split up, some went to [three existing villages] and some went to build [three new villages, one of which was the village we were in].

The information I requested from my informant was about places and village migrations, not church buildings. But as this narrative (as well as other narratives I recorded) clearly shows, in the more recent past since Christianity was introduced in the interior of Buru, church buildings - especially named church buildings (like Betania or Marinata) - have come to be another metaphor of time and place. Now people's movements across the landscape and through time can be referenced by church buildings. Perhaps this is because named church buildings create an easy device for remembering the complex histories about the migrations of great-grandfathers and grandfathers across the landscape. Still this knowledge of the recent past is actually far less important and much more forgettable than knowledge about the distant past which is preserved and hidden in the simple narratives of noro origins. 


\section{Taboo Places}

The Buru places considered in this section are called net koit, a phrase meaning "avoidance place" or "taboo place". Avoidance here does not mean that these places are places to be avoided; rather, when an individual is at such a place, avoidances or taboos must be observed. There are numerous "taboo places" on the island; they are of various sizes and their taboos are varied. As people frequently comment, "many different places, each has its own taboo" (neten-neten tu nake koin). ${ }^{10}$ This means that to walk through the jungle to go to the garden, to go to a different village, to go hunting, or even just to collect firewood, individuals often need to know numerous taboos associated with numerous places.

In these instances the discourse about place concerns taboo. People often talk about these places to instruct their children (as well as outsiders) and to remind themselves how to act. "If we do not follow a taboo, if we 'jump over' (tinggao) it", people say, "sooner or later bad consequences or punishment will beat us (baut paha kita)". Like the taboos, these punishments vary. They can be "big" or "small" and people may "carry the punishment on their backs" (wada baut) until they die or their children die. In talking about taboos often people also mention conventionalized ways to get around a taboo, ways to accomplish the same thing while avoiding the undesired behaviour. The general pattern for talking about "taboo places" is to combine all these elements. First the place and the taboo are stated, then the punishment, and finally the alternative action is described.

For example, when people talk about a taboo place at a stream called Wae Gogon they say,

The taboo of that place is that we cannot say "mosquito" (senget) or "the biting thing" (inhadat). ${ }^{11}$ The punishment for "jumping over" this taboo is that mosquitoes will bite us and we will not be able to sleep. Instead of saying "mosquito" at Wae Gogon, say "young girl" (anafina emhuka).

Another example pertains to the lake at the centre of the island. It is taboo to say the word emhein ("wave") there, because waves will come up and anyone on the lake in a canoe will drown. Instead of saying emhein, people should say ahut to refer to waves.

Some places have non-linguistic taboos as well as linguistic ones. To cross the Wae Fakal stream, a person must not wear a hat. The punishment for doing so: great wind, rain and floods. While people may collect water, bathe, wash clothes and dishes at Wae Fakal, children are not permitted to play there.

The largest taboo place on Buru is called Garan, an area between the lake in the centre of the island and the north coast in the vicinity of the Wae Nibe River (see Map 1). There are no villages in this area and it requires two days to walk 
from one side to the other. It's taboo: do not speak the Buru language. The punishment: disaster will strike, wind and heavy rain will come, sickness will break out. How to avoid the taboo: instead of speaking the Buru language, speak the Garan language (Li Garan).

The phenomenon of a "taboo language" on Buru was noted by a colonial official in 1933 (Jansen 1933). Linguistic and social aspects of this "language" have been discussed by C. Grimes (1991:40-42; also Grimes and Maryott 1994), including the effect of this and other localized taboos on dialect variation. Grimes notes that technically Li Garan is neither a dialect of Buru nor a separate language. It can be considered a special speech register developed entirely around taboo:

The syntax of Li Garan is the same as that of the Buru language. In looking at the lexicon, one can generalise that content words (such as nouns and verbs) tend to have a very general Li Garan term substituting for both generic and specific terms in the common Buru register. Functors (such as prepositions, deictics, aspect markers, verbal auxiliaries, pronouns, numerals, discourse markers) tend to be the same in the two registers (C. Grimes 1991:41-42).

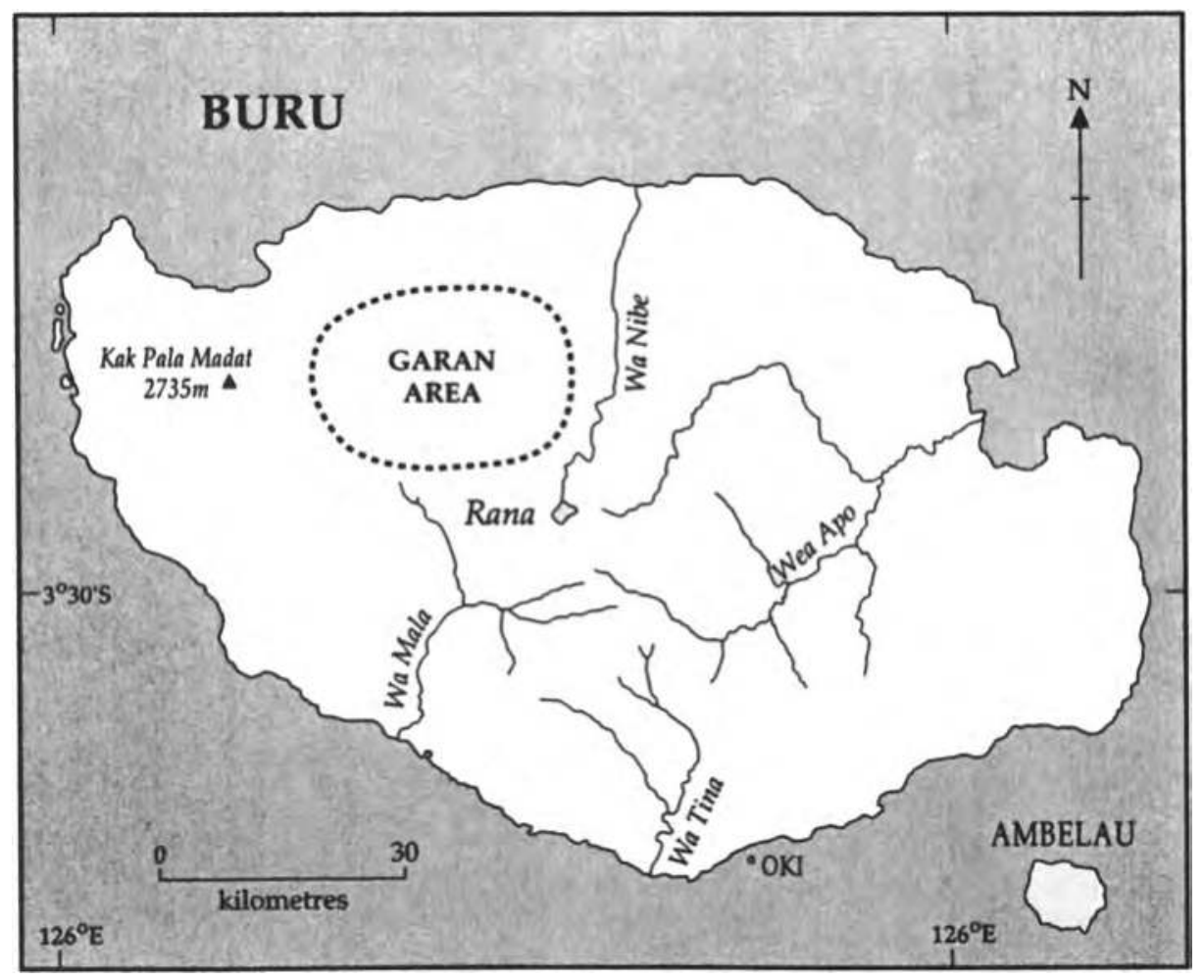

Map 1. The island of Buru 
People who live around the lake teach their children to speak this language from the time they are very small so that they will know it when they are in Garan. To speak Li Garan is greatly valued; people also use it as a secret language away from Garan. The relevant point is that Li Garan functions like other Buru taboo behaviour: it is a way around a taboo. As Buru people quickly point out though, it is not that people must speak Li Garan only in Garan, nor that they can only speak Li Garan in Garan. People can speak Li Garan wherever they like. And we were often assured that visitors to Garan who do not know Li Garan may speak Malay, English, Chinese or indeed any language other than the Buru language. That is the taboo of the place.

The question to ask not only about Garan, but about all "taboo" places, is why taboos are required there. From Buru cosmogony it is clear that the Buru landscape is inhabited not only by visible humans but by non-visible beings as well. They are conceived as having certain commonalities, and the same term used to refer to humans (geba) is also used to refer to some non-visible beings. Both kinds of "creatures" came into being through the supra-human noro founders said to have given "many births". The founders first gave birth to spirit beings who were initially visible but became non-visible. (Even non-visible, they remain agentive beings and can be the cause of good as well as bad outcomes.) ${ }^{12}$ The founders then gave birth to humans, thereby establishing their position as the origin or source of the people belonging to their noro. The narratives make clear the temporal sequence is of "spirits first, then humans"; in other words, elder spirits and younger humans.

In certain places in the jungle, spirits called "lords of the place" (geba neten tobon) are especially important because they are considered to be "owners come masters" (duan) of the wild animals in their domain. Just as human owners in the village feed their animals, these spirit owners in the jungle feed theirs. The masters of the wild pigs and deer are specifically called (sanane), while the masters of the cuscus and birds are called (geb rawa). There are many sanane and geb rawa throughout the jungle, and people know their names and the specific trees in which they live and where they feed their animals. ${ }^{13}$

Since these spirits are the masters of the wild animals, hunters must show respect and offer prayers to them saying, "Please, Sanane, give me a wild pig today" or "Please, Geb Rawa, may you let a cuscus get caught in my trap". In certain places, so as not to offend nor to make the "lord of the place" aware of their intent, hunters do not say the name of the animal they are hunting. This creates one motivation for the prolific taboos associated with hunting, which are always restricted to a certain locale: "In such-and-such a place do not say "pig'. If you do, you will not catch a pig." It is important to be quiet around those trees in the jungle considered to be the "houses" of the "lords of the place" in order to avoid annoying the lords or making them aware of one's presence. 
When walking near these places parents remind their children in forceful whispers, "Don't be loud, it's taboo" (Bara hean moo, tu koin). The goal is to walk by these taboo places as quietly and quickly as possible without causing any "offense or wrong" (sala).

At Buru taboo places the establishment and maintenance of proper relations is being enacted through a high degree of avoidance behaviour. Relations (particularly asymmetrical ones like elder-younger) are never taken for granted, but are continually discussed, evaluated and re-expressed through behaviour fitting to the relation. In addition to the relation between spirits and humans, numerous other Buru relations are also constructed in terms of avoidance. Beside "taboo places" there are "taboo things" (ii koit) like the heirlooms of the noro, and "taboo people" (geb koit), certain affines to whom individuals must "show custom" (tahu adat) or proper behaviour by avoidance. What is constructed in all these taboo places, people and things is an asymmetrical relation predicated on separation and which demands social distance rather than social intimacy in people's behaviour.

On Buru social distance is not externalized through positively defined behaviour ("Do this to show respect"), but through avoiding behaviour that suggests familiarity and would thus negate the relation ("To show respect, don't do this [behaviour suggesting familiarity]"). This is particularly clear in the behaviour required towards affines. There are numerous things one cannot do in the presence of affines, who are considered taboo (geb koit). But these "taboo people" are contrasted with others who are "easy people" (geb dape), people with whom familiarity and intimacy is possible, where relations require no social distance or avoidance. The spirits in the jungle are analogous to "taboo people". There are numerous things one cannot do in their presence. Being non-visible, however, these spirits are known through the metonym of place.

It is important to know these places, because behaviour that "forgets" or negates a proper relation will have unfortunate consequences. An "offence" (sala) toward spirits who are "elder", and in some cases the previous owners of animals, can "close" (tregu) offenders in their pursuits of life: they will have no success, their children or other family members may become ill and die. In seeking the cause or "root" (lahin) of an illness, the past behaviour of the individual (and of his or her relatives) at all known taboo places is reviewed to discern if some offence was committed. ${ }^{14}$ If there was an offence, the situation is rectified through prayers and requests for forgiveness, although sometimes it is necessary to sacrifice a chicken or pig as well. In a similar way, people also re-establish proper relations between themselves by "asking forgiveness and giving gifts of cloth" (eslauk) when offences have been committed. So in both the visible and the non-visible Buru world, distinct relations are properly 
revealed through distinct and distancing behaviour. Forget this and "punishment" will strike.

\section{Conclusion}

The Buru places discussed here are spaces where social and cosmological relations of origin and precedence are externalized on the island's landscape. At springs in the mountains, individuals and groups find their origins and their source of life and blessing. Along the river systems the precedence of house-circles flows from upstream to downstream. At taboo places precedence is behaviourally enacted by human beings cosmologically junior to spirits. Through these places and relations Buru people define themselves by continually re-affirming their place in society.

\section{References}

Fox, James J.

1989 Category and complement: binary ideologies and the organization of dualism in eastern Indonesia. In D. Maybury-Lewis and U. Almogor (eds) The attraction of opposites: thought and society in the dualistic mode, pp.33-56. Ann Arbor: The University of Michigan Press.

1990 Hierarchy and precedence. Working Paper No. 3, Comparative Austronesian Project. Department of Anthropology, Research School of Pacific Studies, The Australian National University.

Grimes, Barbara Dix

1991 The development and use of Ambonese Malay. Pacific Linguistics A18:83-123.

Grimes, Charles E.

1991 The Buru language of eastern Indonesia. PhD thesis, The Australian National University, Canberra.

Grimes, Charles E. and Kenneth Maryott

1994 Named speech registers in Austronesian languages. In T. Dutton and D. Tryon (eds) Language contact and change in the Austronesian world. Berlin: Mouton de Gruyter.

Hocart, A.M.

1952 The northern states of Fiji (Occasional Publication No. 11). London: The Royal Anthropological Institute of Great Britain and Ireland.

Jansen, H.J.

1933 Gegevens over Boeroe (1928). Adatrechbundels 36:463-489.

Kearney, Richard 
1989 Paul Ricoeur and the hermeneutic imagination. In T.P. Kemp and D. Rasmussen (eds) The narrative path: the later works of Paul Ricoeur, pp.131. Cambridge, MA: MIT Press.

Ricoeur, Paul

1986 Lectures in ideology and utopia (edited by G.H. Taylor). New York: Columbia University Press.

Schut, J.A.F.

1918 Het huwelijk bij de Geb'emliar op Boeroe. Mededeelingen vanwege het Nederlandsch Zendelinggenootschap 62:16-35, 125-140, 197-210, 296-308.

Valeri, Valerio

1990 The genres of knowledge in Huaulu (Seram). Paper presented at Conference on Halmahera Research and its Consequences for the Study of Eastern Indonesia. Koninklijk Instituut voor Taal-, Land- en Volkenkunde, Leiden, October.

\section{Notes}

1 All vernacular terms of the Buru language are in Palatino italics, while all Indonesian terms and those of the Ambonese Malay lingua franca (see Grimes 1991) are in Helvetica italics. The occasional French and Fijian terms also appear in Helvetica italics.

${ }^{2}$ While Buru people emphasize that this is one language, they also recognize internal differences. Five major dialects can be distinguished (C. Grimes 1991:35-36).

${ }^{3}$ When Hocart described Lau categories of spirits in Fiji, he found that a class of spirits called $v u$ (which he also referred to as "gods") had as their chief characteristic "originating". He also noted "the Fijians are very careful to distinguish between the spirits of the dead and these [vu] gods" (1952:9). While admitting the difficulty of finding an adequate gloss for $v u$, Hocart referred to them as "founder-gods". The founders of Buru noro are similar. They are spirits, but not spirits of deceased human ancestors.

4 Other factors such as language and "custom" (adat), are also important in group identity. But from a Buru perspective, the primary factor is origins. Other people speak other language because they have non-Buru origins, not the other way around. In other words, it is not because they speak other language that people are attributed non-Buru origins.

5 A tributary of the Wae Mala River.

6 In this text I have changed Schut's original orthography to reflect current orthographic practices on Buru. Many of these differences parallel changes in the Indonesian orthography.

7 Gereja Protestan Maluku [Protestant Church of Maluku], the heir of the Dutch colonial Indische Kerk in Maluku.

8 Sidang Jemaat Allah, the Indonesian branch of the American-based Assemblies of God Protestant denomination.

${ }^{9}$ Like any other buildings made out of native materials, church buildings have to be replaced or rebuilt every five to ten years.

10 When $-n$ is attached, the root koi- is nominalized and can be glossed as a noun: "the taboo" or "its taboo".

11 Both senget and inhadat are taboo-generated avoidance terms for "mosquito" which are fully assimilated into different dialects (C. Grimes 1991:35 and Grimes and Maryott 1994).

12 Other Buru names for generic categories of these spirits are jingi and setan, both originally from Arabic (C. Grimes, personal communication).

13 One place in the interior of the island was labelled on several Dutch maps as Sanane Puun ("Sanane Shrub"). 


\section{The Poetic Power of Place}

14 This behavioural review process that occurs whenever something bad happens contributes to the on-going creation of new taboos. If no obvious sala can be discerned, the misfortune must be because of some previously unrecognized taboo. The situation is discussed until those concerned reach some conclusion about the cause of the sala, effectively creating a new taboo. I suggest this also contributes to the idiosyncratic nature of many taboos, as the sala is discerned by examining the recent behaviour of those involved. What they did may have been very mundane and ordinary in other contexts, but it turns out to have been taboo in that place. 


\section{Chapter 8. Speaking of Places: Spatial poesis and localized identity in Buli}

\section{Nils Bubandt}

\section{Introduction}

This paper seeks to explore the nexus between language, space and identity. ${ }^{1}$ It does so by focusing on the frequent use of orientational or deictic words in Buli language and relating it to the processes of identification. Spatial deixis seems to be relevant to the processes of identification at two levels: those of individual subjectivity on the one hand and those of cultural identity and differentiation on the other. In this discussion of the relationship between the perception of space and forms of identification I hope to suggest a possible connection between the numerous descriptive analyses of orientational systems in eastern Indonesia (Adelaar 1997; Barnes 1974, 1986, 1988, 1993; Taylor 1984; Teljeur 1983; Shelden 1991; Yoshida 1980), the discussion of subjectivity and the role of deixis in phenomenological linguistic theory (Benveniste 1966; Bühler 1982; Lyons 1982; Fillmore 1982), and broader debates on the spatial processes operative in cultural identification.

The basic argument is that the same linguistic conventions for spatial orientation in Buli function to posit both individual subjectivity and cultural identity. At the former level, spatial deixis establishes the speaker as a "locative" subject with a defined but relative position in the world. The subject necessarily occupies a place in space and, in most acts of speaking, posits this. ${ }^{2}$ I shall argue that subjectivity in Buli is posited continually in speech through spatial deixis. At the broader level of cultural identification, however, space is laid out in absolute terms. Here, space terminates in certain culturally significant "heterotopias" (Foucault 1986), that is, places of important symbolic difference to Buli. Deixis establishes through these heterotopias a spatially grounded, moral sense of cultural identity. Arguably, "cultural identity" is better described as a localized sense of belonging (Appadurai 1995). If this is the case, one needs to determine how this localization of a "sense of belonging" is established. As I shall try to show, the "spatial poesis" that locates the subject as a positioned social agent also creates the basis for a spatially defined sense of cultural belonging. Thereby I hope to inscribe the discussion of spatial orientation within the recent theoretical critiques of anthropology for its assumption of an "unproblematic link between identity and place" (Gupta and Ferguson 1992:7). I suggest looking at spatial deixis, the intersection between discursive space and 
spatial praxis, as an avenue for engaging the social and historical construction of the link between identity and place in Buli.

The direct impetus for my interest in deixis came not only from anthropological theory but also from repeated difficulties in coming to grips with the system of spatial orientation in Buli during fieldwork in the Buli village of Waiflí between 1991 and 1993. I will describe one instance of these conceptual difficulties below, not just as a convenient allegory for introducing the Buli terms of spatial orientation but also because, in retrospect, it was my own confusion in instances such as the one described below which prodded me to think about the dynamic and poetic function of space in constructing selfhood and cultural identity.

Buli is an Austronesian-speaking group of about 5,700 people dispersed in nine coastal villages on the east coast of Halmahera in north-east Indonesia. Traditionally, Buli people are horticulturalists and fishermen with a subsistence economy relying mainly on sago and coral fish. However, integration into a wider market economy promoted formerly by Dutch colonial officers, now by Indonesian state officials and a motley group of Chinese, Bugis and Buton entrepreneurs, has meant an increasing dependence on cash crops like copra and cocoa as well as on the commercial exploitation of the ocean, in particular of anchovies, bêche-de-mer and sea shells. The Buli language is one of seven Austronesian languages spoken in the northern part of the Indonesian province of Maluku (known in English as the Moluccas). While the southern part of the island of Halmahera is populated by Austronesian-speaking groups such as Buli, Maba, Patani, Gane (Gimán) and Weda (Sawai), the northern and more populous part of the island is inhabited by Papuan-speaking groups, the most prominent of which are Tobelo, Galela and Loloda. Until their abolition by the Dutch, two sultanates, Ternate and Tidore, had nominal political dominion over the island of Halmahera. Both sultanates derived their power from their control of the lucrative trade in cloves which, over the centuries, had lured traders from Asia and Europe to their ports. While the northern part of Halmahera claimed loyalty to Ternate, the southern part of the island, including Buli, paid tribute to the Sultan of Tidore. 


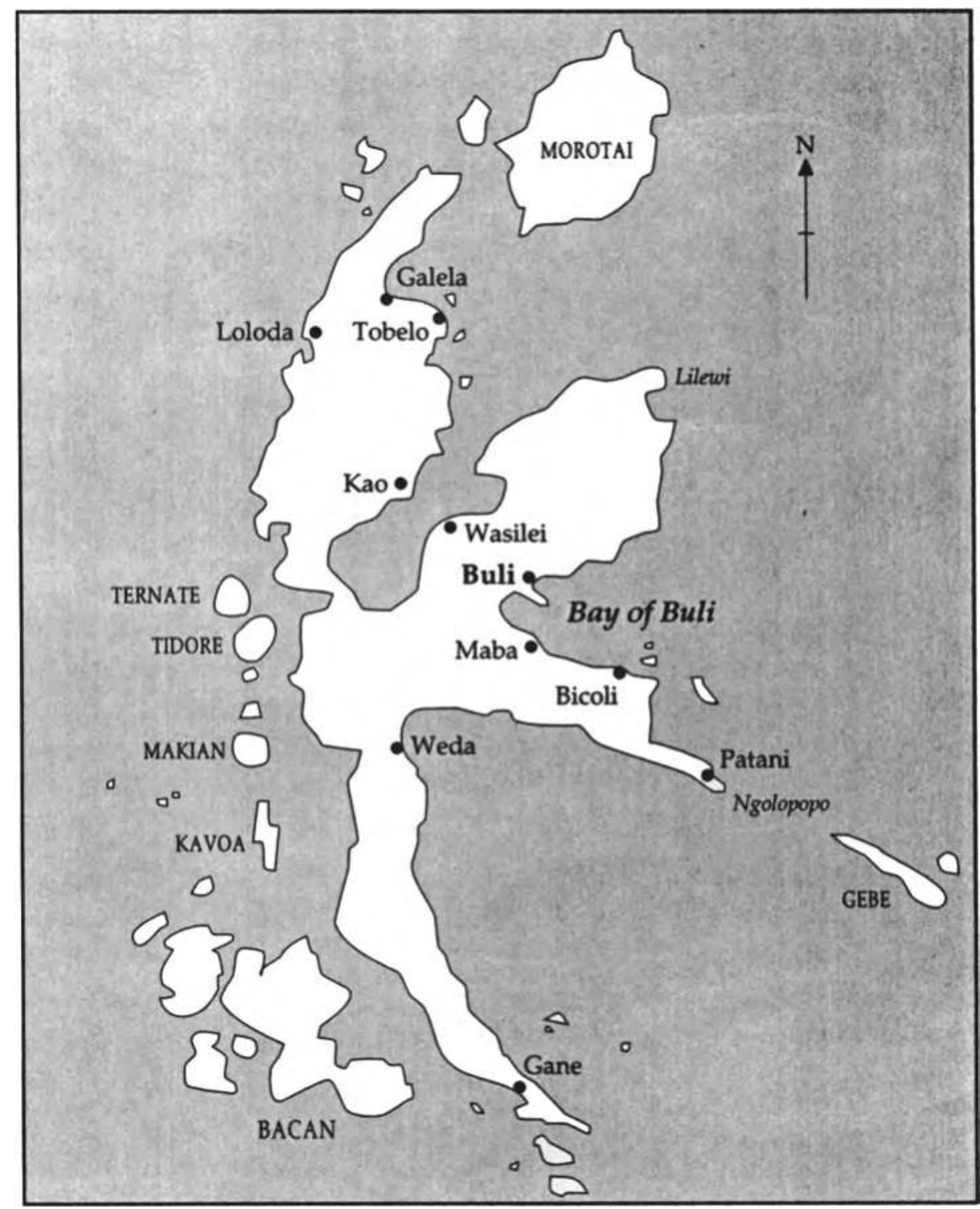

Map 1. Halmahera, showing the Bay of Buli

\section{The Spatial Conditions of Subjectivity in Buli}

Let me, as promised, introduce spatial deixis in Buli with a story. One day I went fishing with Lingoro and his son-in-law, Enes. We set off before dawn and headed straight for a well-known fishing spot near the island of Femlawas. The island lay in the mouth of one of the numerous small bays on the east coast of Halmahera and the fishing spot, a deep coral reef hidden from the eye, lay between the island and the oval shore of the bay. The canoe was drifting with 
the wind and spun around itself in a slow dance but Lingoro kept us in place over the reef with the occasional wiggle of his paddle from his seat in the bow of the canoe. Suddenly, his line was bitten off deep below, probably by a toadfish whose sharp, parrot-like beak is a scourge to any fisherman without proper metal tackle. The fish were otherwise biting well at the time and Lingoro was eager to get his hook replaced, so he asked me, slightly impatiently, to hand him his box of hooks "on the landside" (Moce yanik awil poléi tasá). At the time the canoe's slow rotation had me facing a promontory of the mainland, while I had the island of Femlawas roughly to my right. The coastline of the mainland of Halmahera continued from the promontory in an arc almost 180 degrees to my left and was visible even as I turned around to look behind me. I could in other words see land to all sides. I sensed I was surrounded by land and could not decide where "the landside" might be. As I began rummaging around to all sides looking for the hooks, Lingoro realized, after twice repeating: "No, to the landside!" (En pa, poléi, poléi!), that I would never find his hooks in time and he scrambled across the outrigger to get the box himself. It was hidden under a pandanus mat on my left-hand side which pointed in the general direction of Watileo and the other mountains of the interior of Halmahera.

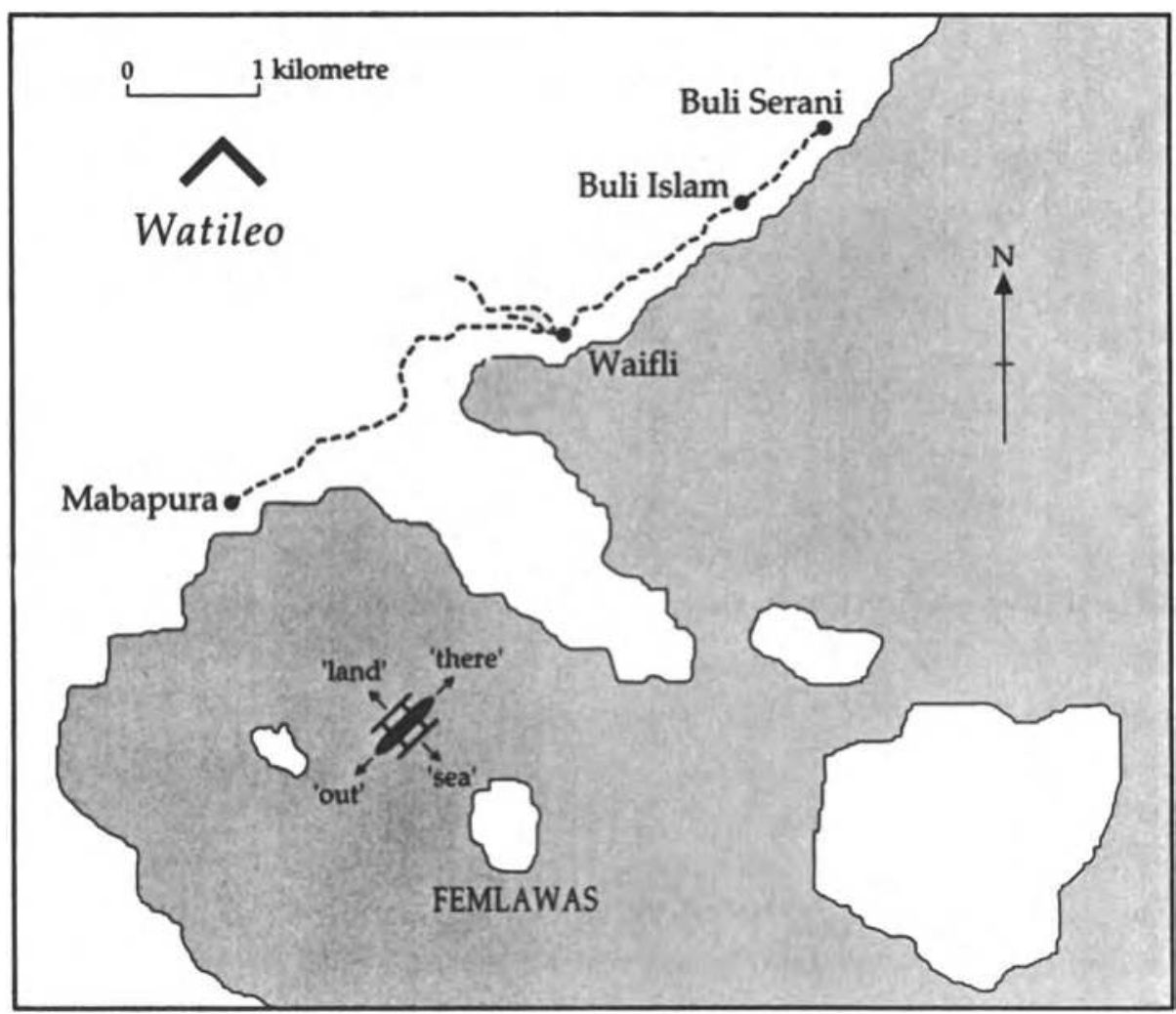

Map 2. The central orientational axis, Buli 
With a new hook attached and his annoyance abated, Lingoro explained that neither the island to my right nor the arc of the bay curving both ahead and behind us counted as being "on the landside". What to me seemed an arbitrary spatial designation in a vaguely similar landscape, to Lingoro was a necessary directional indication as precise as a pointing index finger. As it turned out, however, it was not an absolute one: the exact direction of the landside was a function of our location. Thus, when later on we put onto the beach on the island of Femlawas to roast a few fish for lunch, Lingoro ordered Enes to the "landside" to gather firewood. In going to the "landside" towards the centre of the small island, Enes headed in a direction exactly opposite to the "landward" direction of a few hours earlier when we were out at sea.

By the standards of its other Austronesian neighbours, there is nothing unusual or particularly complicated about deictic terms of space in Buli. Similarly, surprise and confusion such as mine in coming to terms with an Austronesian spatial system has not gone unreported in the anthropological literature (for example, Barnes 1974:84; Barraud 1979:26; Firth 1970:191). After fieldwork in Kédang off the east coast of Flores, Barnes (1974) was the first anthropologist working in Indonesia to take an analytical interest in the orientational system he encountered, although the complexity of spatial terms had been remarked upon by Dutch missionaries since the nineteenth century (for a mention of Buli terms, see Maan 1951:91). It goes for Buli, as for Kédang, that the application of a particular spatial marker (such as for instance "on the landside") is not consistently oriented toward a particular feature in the landscape, as I had vaguely expected. Rather, as one's position in space moves, so too do the possibilities for assigning features in the landscape to act as reference points. Deictic terms are oriented and applied within a matrix of space that changes as one moves around it. ${ }^{3}$ My fishing story sought to illustrate this point. Not every region of the mainland qualified as being "on the landside". In the canoe at sea, neither promontories nor lowland areas of Halmahera counted as "landside". Only the narrow direction of the central mountains could appropriately be designated as "landward" in this instance. This does not mean that the mountains always define "land". Instead, the allocation of a given locative, such as "landside", depends on one's own position in space and not on cardinal points that remain the same wherever one is. In the outrigger at sea, the "landside" was in the direction of the central mountain range of Halmahera, because here the spatial reference was the island of Halmahera. Once we landed on Femlawas, the spatial reference had shifted to this small uninhabited island and "landside" was therefore naturally defined by its central point.

\section{Basic Orientation in Buli}

As in most other Austronesian societies (Adelaar 1977:1) as well as in many Papuan languages such as those of north Halmahera (Taylor 1984; Yoshida 1980), 
the landward and the seaward directions form the central orientational axis in Buli. ${ }^{4}$ This axis is always complemented by other axes. In Buli, five sets of locatives are used to order orientation within the social world. Apart from "landside" (poléi) and "seaside" (poláu), the two most used are: "up" (puis) and "down" (pap) and "inside" (pomúl) versus "outside" (potá). ${ }^{5}$ The lexeme li, literally meaning "place" and found in many place names, ${ }^{6}$ is used in the locative poli to mean "over there". It is employed in a vague sense as opposed to mantane ("here") but it also occurs as a locative related to the directionals lali ("towards there") and mali ("towards here"). ${ }^{7}$ The fifth deictic set denotes movement "upstream" (solat) and "downstream" (yeli) but this is used less often, mostly when moving in the forest where paths almost always follow streams and waterways. On the coast, this set coincides with the "landward"-"seaward" axis. These five axes define different points of orientation that are not fixed locations in physical space but are, as the story above illustrated, dependent upon the contextual location of the speaker in space. If we take a speaker located in an ideal centre of the village of Waiflí as an example, the world is spaced around the speaker (who is represented by a circle) (see Figure 1).

As a rough guide one could say that the landward-seaward axis runs perpendicular to the coast, while the upward-downward axis runs parallel to the coast. The two axes are mutually organized so that when one faces the coast, downward is to one's left. However, it is important to remember that this is not a generally valid schema for orientation. It is correct only from a position in the village of Waiflí. Although one follows the upward direction as one approaches Waiflí from the north along the coast, it is strictly speaking not possible to go in an upward direction once one enters the village. As we shall see, this is because the village defines the most "upward" point within the Halmaheran world. Instead potá ("outside") takes over briefly as the designation for one's southerly direction, but one is quickly cut short on one's walk to the "outside" along the beach by cliffs and mangroves. Instead a path takes the traveller in a direction towards the "landside" across the large promontory to the south of Waiflí until one emerges near the village of Mabapura on the other side. In general terms, the "landside" is the direction of the forest and refers in particular to two forest paths that follow the small village stream to the coconut groves, sago swamps and cassava gardens that separate the village from the forest. "Over there" (poli ) is a medial location which from the ideal position in the centre of the village is situated between the "inside" and the "down" positions (see Figure 1). In the village poli is the location of the village primary school and further sago groves. 


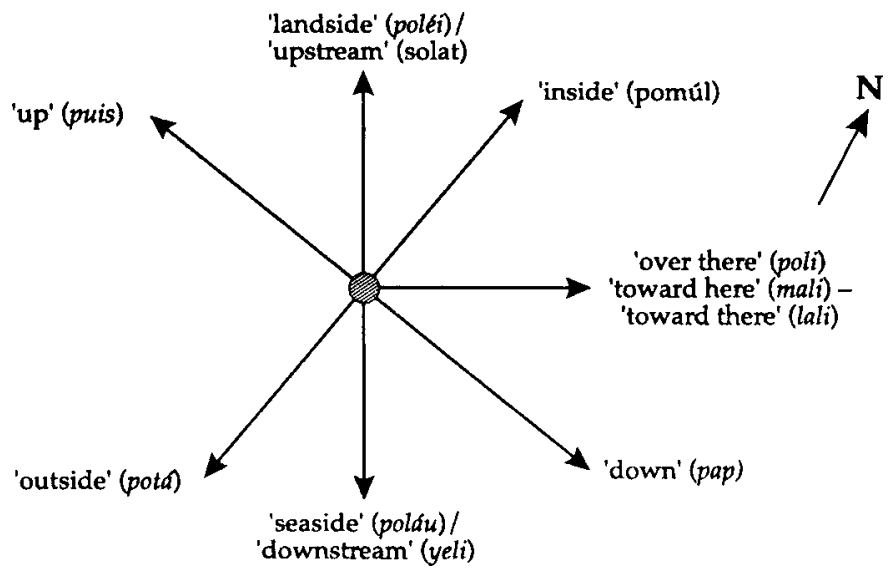

Figure 1. Matrix of spatial location in the village of Waiflí

Within the village, the "seaside" indicates the direction of the beach. If one answers that one is "going seaward" (fan laláu tane) to the greeting "where are you going?" that is an inevitable part of social interaction, it is generally understood as a polite euphemism for going to the beach to relieve oneself. The seaside is, of course, also the direction of the ocean itself with its resources of fish, turtles and sea shells. While both the sea and the land are exploited in the traditional economy of Buli society, there is a greater degree of reliance and emphasis on the sea and this is reflected in the different degrees of comfort associated with the spatial domains of land and sea, respectively. As one man explained it: "the sea is open: you can see all around. The forest is closed and dark, you just have to be afraid". The conception of the forest as a "closed" domain one enters "into" is also harboured in the word for "forest", ai loló , which literally translates as "tree-inside-of". The logic of the land as a closed, dangerous space and the sea as an open, safe space also motivates the approximation of "inside" to the "landside" and "outside" to the "seaside" in the context of orientation within the village (see Figure 1).

\section{Relative Distance and Movement in Deixis}

The directional terms I have mentioned here are combined with two other types of orientational devices that help locate objects and actions in the world. The first type is a prefix that indicates movement in relation to the speaker. It occurs in three forms: la-, $m a-$ and po- and is attached to the deictic root words such as "land" (lei) and "sea" (lau). La- (which also occurs in the form na- in for instance nap, "downward" and nais, "upward") describes a centrifugal movement away from the present position of the utterance. La-léi means, for instance, "in a direction towards the landside away from the present position of the speaker". $M a$ - could be called the centripetal form and indicates movement towards the speaker. Therefore ma-léi means "from a point in the landward direction moving 
towards the speaker". Finally, po- indicates that no movement of significance in relation to the speaker is occurring. This was the form used in Figure 1. Po-léi means (as in case of the fishing hooks) "somewhere in the region defined as landside from the speaker's current position". It may refer to an immobile object or person or to a person whose movements remain within a domain that is seaward from the place of the utterance. The second type of directional device, inevitably combined with locatives in deictic or pointing phrases, is a demonstrative that gives a sense of relative distance from the speaker. These demonstratives come in three forms: tane, nea, na. Tane means "here" and indicates very close, usually tactile, proximity; nea implies relatively close proximity somewhere beyond easy reach, while na denotes relatively far distance.

If we add these two types of devices, the radial prefixes and the distal demonstratives, to the orientational schema of Figure 1, we get movement, distance and direction as illustrated in Figure 2. Again, this is not a general representation of abstract space, but a depiction of how space would unfold from a particular position (somewhere in the centre of the village).

\section{Placing Things and Using Space}

Locatives, radial prefixes and demonstratives marking distance are combined to express relative position, distance and direction of movement. So, for instance, poláu tane means "on the seaside close to my present position". Nap nea means "in a downwards direction some distance away from my present position and moving away". Pap na mais means "on a distant location down there but moving towards my present position in the upward region". Objects and events are almost invariably situated spatially in this fashion, which is especially clear in noun phrases such as: 


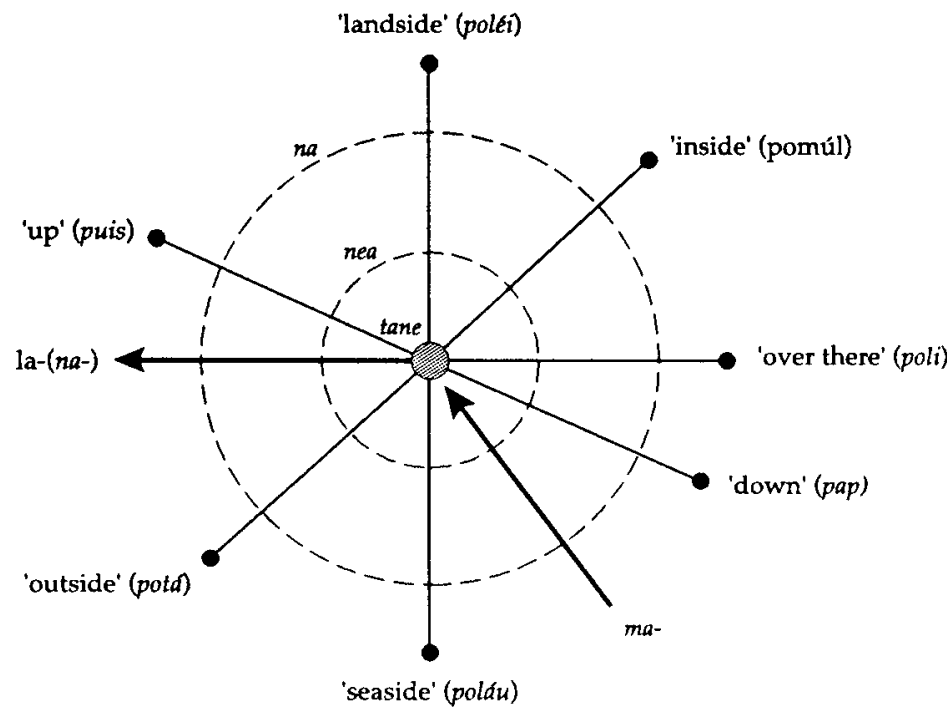

Figure 2. Movement, distance and direction in Buli deixis

$\begin{array}{lllllll}\text { Nim eta } & \text { ca, ya } & \text { i-sispe } & i & \text { poláu } & \text { nea' } \\ \text { Your } & \text { knife } & \text { the, I } & \begin{array}{l}\text { ls-stick in } \\ \text { the wall }\end{array} & \text { it } & \begin{array}{l}\text { on the } \\ \text { seaside }\end{array} & \text { close there }\end{array}$

"I stuck your knife in the wall over there on the seaside."

In one short sentence the relative positions of speaker and knife as well as the distance between them are situated in relation to the landscape around them. The speaker is inland from the knife, which is some distance away (out of reach) towards the beach. There is no need to point; the location is pin-pointed without gestures. The sentence also presumes that the addressed person (the owner of the knife) occupies a position within the same spatial co-ordinates (in this case "landside" and "seaside") that makes it possible for the owner of the knife to triangulate the position of the knife by knowing his or her own position in relation to the speaker. The owner of the knife knows the knife is located "to the seaside" a short distance from the speaker. Intuitively, the owner of the knife also knows his or her position and distance relative to the speaker. With these two bits of information, the owner will be able to know the position of the knife with relative precision.

Because the relative location of interlocutors and objects referred to (as well as the relative distance and movement, if any, between them) is always implied in speech, language posits space in a profound, ontological sense. Language, by definition, does so within a discourse situation. The ultimate referent is therefore not an isolated subject but, rather, a moving, speaking actor relative to another actor. Since space in this way is posited in dialogue, the ultimate referent of 
spatial location is the shared space of the interlocutors: my place in the world is intelligible only in relation to the common space that I share with other people. Within this space, however, my location differs from that of others. Points in the landscape help me situate myself, but they do not do so absolutely, nor are they the ultimate fix points for anchoring myself in the world, for as I move so do my spatial points of reference. ${ }^{8}$

In the introduction to his Outline of a theory of practice, Bourdieu (1977:2) makes a distinction (as a metaphor of theoretical objectivism and his own practice theory, respectively) between orientation with the aid of a map and what he calls "practical mastery" of space. While the former type of orientation is based on a Cartesian notion of space with privileged positions and cardinal points, "practical mastery" relies firstly upon "the system of axes linked unalterably to our bodies, and carried about with us wherever we go" (1977). Practical mastery or the ability to know one's way around is achieved by bringing together these bodily defined axes and "the axes of the field of potentialities" (1977). In his interesting article on the role of mental maps in orientation Alfred Gell rejects, wrongly I think, Bourdieu's notion of "practical mastery" as an example of an "ego-centric" notion of space. As an argument for his rejection, Gell asserts that "[w]e are obliged at all times to locate our bodies in relation to external coordinates which are unaffected as we move about" (1985:279). I think it pays to return to Bourdieu's original formulation again to see where Gell's rejection of him lost its bearings. Bourdieu is not dismissing the idea of reference to external criteria in orientation. At least this is what I take his notion of "the axes of the field of potentialities" to be in fact referring to. The interesting point in connection with my presentation of Buli deixis is the difference between Gell's "external coordinates" and Bourdieu's "axes of a field of potentialities". The former implies a static space with a uniform spatial grid, the latter what Barnes (1988) has called a "moving space" where the generation of spatial reference itself is context dependent. It is as axes of a field of potentialities defined by one's place in space that the Buli locative terms as shown in Figure 1 should be seen. In defining one's relation to objects and other people within this field of potentialities, one has to align the field to one's own bodily axes as illustrated in Figure 2. Spatial orientation in Buli is thus neither a Euclidean space of absolute reference points nor an egocentric universe completely independent of traits in physical space. The question is whether these extremes are, in fact, "real" alternatives, or whether they do not each portray their own kind of exoticism. While the latter certainly paints a romantic and orientalist picture when applied to non-Western types of spatial perception, the former exaggerates the rational, Euclidean nature of the everyday practice of space in the "West". 9 Although Buli notions of space are different from those in the "West", we might ourselves not always be as Euclidean as philosophers and anthropologists tend to portray us. Only rarely in everyday life do we rely on the fixed cardinal points of the 
compass. Most of the time we orient ourselves by a much more relative, bodily kind of deixis by which we manage to locate ourselves in the world without employing the fixed points of north or south (but see Barnes 1985:210 for an example). The most obvious examples are such deictic words as "here" and "there", "left" and "right". However, for all their obviousness, the role of these and other deictic words in language is not as straightforward or unimportant as one might assume. In fact, deixis plays a crucial role in the linguistic mediation of our selfhood.

\section{Space, Subject, Body}

For Emile Benveniste, the French linguist, subjectivity is constituted only in and through language. In language we achieve our subjective sense of self through the act of speaking and this linguistic subjectivity becomes the foundation of subjectivity outside language as well (1966:263). Subjectivity is established by the necessity in every language to identify who speaks, either through a personal pronoun ("I" in English) or through verb modality (1966). ${ }^{10}$ The linguistic act of "pointing out" the speaker is so fundamental, argues Benveniste, that a language which does not have the capacity to identify the person speaking cannot be understood. Benveniste's contention is that the speaker comes to think of him or herself as a subject through the linguistic obligation to say "I". However, personal pronouns cannot achieve the task of installing subjectivity on their own. Deictic words that establish the temporal and spatial location of the speaking "I" are indispensable for the task of installing subjectivity in a "here" and "now" (1966:262). Without constant reference, either implicitly or explicitly, to the temporal and spatial location of the " $\mathrm{I}$ " in speech, language would be just as unintelligible as it would be without the personal pronoun. At least this is the assertion of the German psychologist and linguist Karl Bühler. ${ }^{11}$

In an utterance the speaker makes, according to Bühler, a threefold reference. Firstly, the speaker posits him- or herself as a speaking individual, designated by the personal pronoun "I". Secondly, the speaker refers to a temporal dimension in the utterance, such as by using verb tenses or employing words like "tomorrow" or "last year". All such temporal references are ultimately anchored in and defined from the "now" of the utterance. Thirdly, the speaker places the utterance in space with deictic words like "this", "there" or "left". Again the reference point of spatial deixis is the place of the utterance, the "here". In Bühler's terminology "origo" is this fixed point in space, time and individuality that the utterance creates by establishing the identity of the speaker ("I"), a position in space ("here"), and a moment in time ("now"). An illustration of Bühler's (1982:13) threefold location is given in Figure 3. 


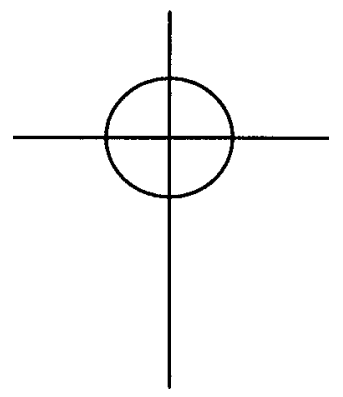

Figure 3. Bühler's deictic "origo"
The central circle representing the origo is the point of conflation of the dimensions of time and space in each individual enunciation. The "I-here-now" of the origo is the individualization in discourse of the temporal, spatial and social dimensions of life that posit the individual and make its speech intelligible by locating its fix-point. In other words, language posits subjectivity which is, in turn, necessarily located in both time and space. It is in this sense of perspectives from an origo that I suggest Figures 1 and 2 should be understood. The circle indicating the limits of the Buli deictic word tane in Figure 2 corresponds to the " $\mathrm{I}$ ", "here", "now" origo in English. Tane is interesting in this connection because it has several connected meanings. In addition to meaning "here" (where it also occurs as mantane) proper demonstrative, tane may also mean "this" and as a temporal demonstrative it may mean "now" (Maan 1940:110). Since tane means both "here" and "now", it defines the temporal as well as spatial origo of Buli deixis. The Buli sentence yai tane, "I am here-now", would thus encapsulate the origo of Buli utterances in the same way that the implicit reference to "I", "here", "now" does in English. Yet, the obvious difference is that the Buli origo exists within an elaborate deictic matrix where the meaning tane is not fully developed without the locatives of "landside", "seaside", "up", "down". In English, on the other hand, the "here" of the origo is merely opposed to a vague "there" outside the domain of the speaking "I". Poli, "in a spot over there", may be in vague opposition to the "here" (tane or mantane) of the speaking subject, but it is also a definite region on the horizon of the subject, the exact location of which rotates and shifts as the subject moves through space. The Buli subject is, in other words, situated in a conceptual matrix of practical space, the specific appearance of which depends on the placement in space of the origo of the speaking subject. ${ }^{12}$ In Buli deixis there is thus an emphasis on the relevance of spatial context. In orientation, the "landside" is never an abstract direction in space but always a particular location from a particular place. ${ }^{13}$ The origo of the speaking subject is tied to a conventional matrix of space, without privileged nodal points, that nevertheless links all subjects within a common perception of space. In Buli, spatial orientation is the social practice of known space, and deictic orientation is the constituting act of the subject within this practical space. Space is always conceptualized from particular places. These particular places are the origos of speaking subjects, at once determining the exact appearance of space and determined by the conventional relationship between "landward", "seaward", "upwards", "downwards", "to the inside". 
Although subjectivity is thus established through language, it does not exist there alone, but is only "real" through its link to bodily existence. By necessity, the "I" always speaks from a "here" and "now", which we all intuitively know "in our bones", as it were, and which we tend to make the implicit "zero point" when we speak of "other" times and places. ${ }^{14}$ Speaking of "other" places and times is, one might say, the essential way in which the contours of the "I" are established. The deictic location of the subject in the "here" and "now" necessitates an awareness of the spatial and temporal limits of the speaking "I" as a physical subject. Deixis (and the subjectivity fixed in time and space because of it) relies, in other words, on the ability we all have to feel our body in relation to our surroundings. This body-space interaction Bühler calls Körpertastbild, the "representation of a corporeal feeling of the world". The Körpertastbild is none other than "the axes we take with us wherever we go" to which Bourdieu referred. Bourdieu's departure point is identical to that of Merleau-Ponty when the latter argues that it is only through the primordial spatiality of our bodies, which is fundamental to our being-in-the-world, that we are able to perceive the world (Merleau-Ponty 1962:206). ${ }^{15}$

Cultural variations in the sense of located subjectivity arise, then, from the different ways in which the embodied awareness of one's place in space is absorbed by the symbolic conventions of spatial orientation: how the bodily subject dissolves into the linguistic conventions of its spatial surroundings. If one accepts this premise, an interpretation of the culturally constituted self can ensue from an analysis of spatial categories with as much justification as from the study of socialization, myth, or ritual. To use the above example again, it is in Buli a concrete spatial object, a body, which occupies a position in relation to the knife, the sea (and, by implication, the other spatial directions) and the knife's owner. A sense of being a subject derives from one's intuitive knowledge of how the borders of one's own bodily existence, defined by the outer limits of the tane (here), extend into the wider co-ordinates of the world to all sides. Space in Buli poses a subject of a particular type, namely one connected to the directions of "sea", "land", "up", "down", "inside" and "outside", and in every utterance a spatial distinction to objects and other people is enunciated or at least implied. In locating the knife, the speaker also posits himself within a particular spatial universe where his position is related to, yet distinct from, the position of other interlocutors. My inability to find the fishing hooks was not merely an inadequate understanding of a spatial system but also, more profoundly, a reflection that I was not being a competent Buli subject. In retrospect, my disorientation was comparable to the condition of personal or existential vertigo that Heidegger (1962:233) describes as "Unheimlichkeit", a concept meaning both "uncanniness" and "not-being-at-home". This feeling of anxious discomfort with one's Being and one's relation to the world arises when the everyday taken-for-granted absorption in the conventions of one's 
surroundings suddenly becomes ambiguous. For with the inability to locate objects in the world, the spatial location of one's own existence (the "there" in "Being-there", Dasein) is thrown into chaos and one loses one's sense of comfort, of feeling at home. Spatial deixis in Buli provides, I suggest, the taken-for-granted conventions for a secure absorption of the subject in the world. It establishes the "there" of things in the world and, more importantly, the "there" of the subject's own existence. In this sense, I was not just unable to find a particular object, I was also not a securely situated subject in the Buli language universe. ${ }^{16}$

\section{Seeing the World From Buli}

Just as deixis is involved in the production of subjectivity, it is in extension also instrumental in the production of what Appadurai calls local subjects, "actors who properly belong to a situated community" (1995:205). Spatial deixis, in this sense, is involved in the production of locality which, following Appadurai, may be defined as a sense of socio-spatial belonging attached to a domain of social immediacy and interaction. Seemingly just a linguistic device for orientation, spatial deixis is in Buli also a technique for the cognitive and moral maintenance of the spatial limits for interaction and cultural identification. To quote Appadurai, the reproduction of such a social spatialization "that is simultaneously practical, valued and taken-for-granted depends on the seamless interaction of localized spaces and times with local subjects possessed of the knowledge to reproduce locality" (1995:207). Spatial deixis guarantees the seamlessness of such interaction, because spatial reference is among the most self-evident of all speech acts, seemingly just a verbal "pointing" to an already existing objective space.

The directionals and locatives of Buli deixis have so far only been described as they operate in day-to-day interaction in the village of Waiflí and its close surroundings. However, deictic words extend into the wider world as well. These extensions end in final points in the social landscape from where movement in that direction is no longer possible. If, for instance, one follows the coast from Waiflí to the northeast, one moves in a "downward" direction (nap) until one reaches Cape Lilewi at the northeast tip of the Central Halmaheran peninsula. Rounding this cape along the coast one will begin to move "toward the inside" (namúl) until one reaches Kao. All villages north of Kao such as Tobelo and Galela, however, lie "over there", when seen from Waiflí. Cape Lilewi is, in other words, the final extension "in the downward direction", Kao is the final point for movement "towards the inside", while Galela and Tobelo are the farthest points for travel "over there" (see Map 1).

If, instead of leaving Waiflí along the coast, one moves into the forest, it is termed moving "inland" (laléi) until a point somewhere in the central mountain range of the peninsula. If one continues beyond this vague point towards the coast on the other side of the peninsula and the villages of Dodaga and Wasilei, 
inhabited by a mixed Maba and Tobelo population, one moves "over there" (lali). "Landward" is also the direction towards the Maba villages on the coast southwest of Waiflí as far as the small Buli village of Tewil. Beyond Tewil all villages along the coast until Cape Ngolopopo on the southeast peninsula of Halmahera are in the direction "towards the outside" (natá). This includes, for instance, the coastal villages inhabited by Bicoli people. All places beyond Cape Ngolopopo, such as Weda, are again toward the "landside".

Two directions still need to be mentioned: the "upward" direction and the "seaward" direction. From Waiflí it is impossible to move in an "upward" direction and remain within the known, proximate world of Buli people. Although one moves "upward" from Cape Lilewi to Buli, the village of Waiflí is itself the endpoint for "upward" movement along the coast. This is said to be related to the proximity of the village to the mountain of Watileo, an important signifier of Buli identity, but no one I talked to could explain this correlation in any detail. "Upward" is, however, also the generic direction of the world at large. All distant places whether America, Ambon, Jakarta, Africa or Japan are in an "upward" direction when seen from Waiflí. In addition, the southern tip of Halmahera including Gane and the islands along the Halmaheran west coast (Bacan, Makian, Kayoa but excluding Ternate and Tidore) are also in an upward direction. Also the islands to the east of Halmahera including Irian Jaya are "upward". While the "upward" direction is generic for all distant places, the "seaward" direction is highly specific. Apart from a few uninhabited islands off the coast of Waiflí, the seaward direction refers only to the islands of Ternate and Tidore, the islands of the formerly dominant sultanates of North Maluku. When viewed from Waiflí, and again taking an ideal centre of the village as my example, the canonical directions on the Buli horizon may be represented as in Figure 4 . 


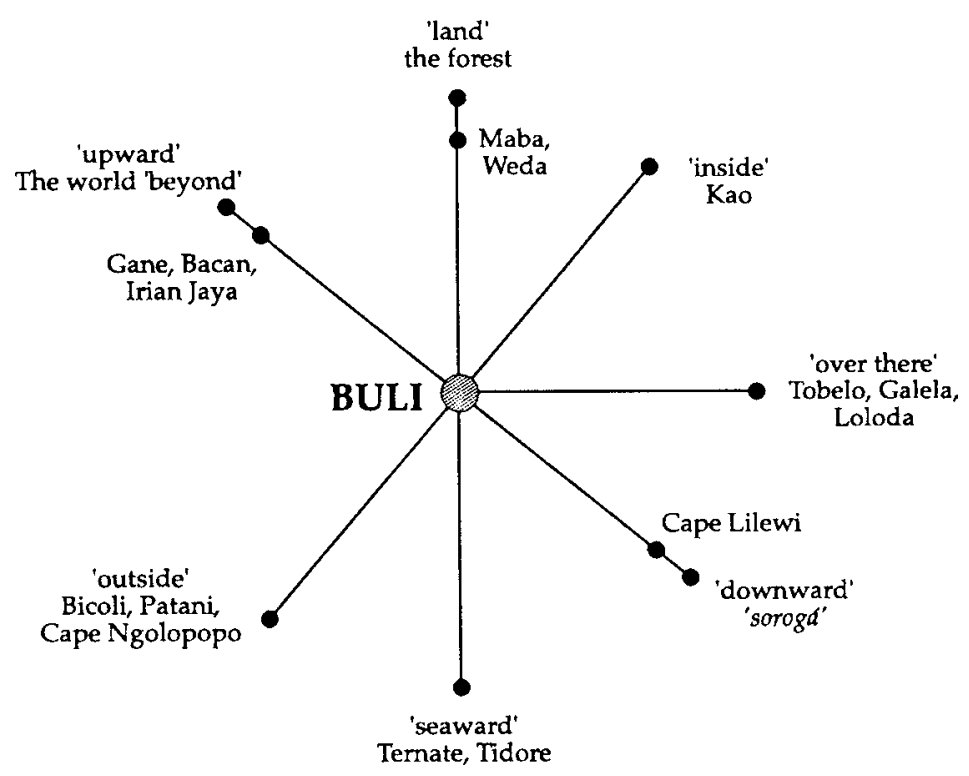

Figure 4. The spatial extensions on the Buli cultural horizon

The logic of these directional applications is partly related to the conventional route one travels to get to each place. Thus to get from Waiflí to Weda one usually goes to Maba by boat and then crosses the central range to the southeast. Logically then, Maba and Weda are points in the same direction associated with the crossing of the peninsula through the forest. The association of the "landward" direction with the forest generally and Maba and Weda specifically is therefore partly encoded in the practice of moving toward these corners of space. Similarly, the fact that the villages of Bicoli and Patani are referred to as "to the outside" is probably related to the raids (known as hongitochten in Dutch) on Papuan villages along the coast of what is now Irian Jaya by Central Halmaheran villages during the rule of the Tidore Sultan. For Buli boats, the villages of Bicoli and Patani, each being a local political centre inhabited by a representative (sangaji) of the Tidore Sultan, were traditional stopping places on the coast to Cape Ngolopopo. Preferring to travel along the coast rather than on the open sea, the cape was a natural jumping-off point to the island of Gebe for onward travel to the Papuan coast. This route meant that the boats were only rarely out of sight of land on the long journey. Bicoli and Patani were the last villages on Halmahera the crew would see on these symbolically very important and hazardous journeys to the faraway regions of Papua, and this fact may account for part of their association with Cape Ngolopopo "on the outside". But the practicalities of routes travelled and the conventions of a spatial practice associated with certain places only account for part of the logic of these spatial canons. More importantly, the association of certain directionals with particular 
places in the social landscape highlights these places as significant points in a moral space.

\section{The Political History of Moral Space}

There is a clear distinction between places in the "upward" direction and places indicated by other directionals. The distant world in general, known only hazily from hearsay, lies uniformly in the "upward" direction. A young boy thus once asked me: "Is your town close to Japan or is it still further up?" (anim pnu ca dahle Jepang lai, fare nais fawé tiná ?). The upward direction is the region of the brave exploits of the hongi raiding expeditions recounted in myths. It is also the region from where strange events and people are telecast on the public television set in the nearby administrative village of Buli Serani every night. This domain is not only "beyond the sea" geographically, it is also politically beyond the realm of the sultanate. From the earliest days of the clove trade the "upward" region was from where increasing numbers of ever more powerful traders arrived at the sultanates by ship, laden with riches beyond the imagination of local Malukans. The traders introduced into the existing network of raids and trade (in which iron implements and slaves circulated) new currencies like Chinese porcelain, brass artefacts and silver coins that Buli people began to obtain on their Papuan raids. Despite this indirect link within an incipient world market, the "upward" region - as defined spatially by the outer limits of sultanate rule - remained the foreign and distant, and this domain of social space was and still is beyond the known world of most Buli. ${ }^{17}$

The "upward" domain is thus both socially and morally distinct from the rest of social space: it is the foreign, the distant, the invitingly prosperous yet treacherous unknown. In order to explain this distinction, I find Alfred Schutz's (1967:xxvii) differentiation between consociates and contemporaries useful. Consociates are those people of whom one has direct, face-to-face experience. Consociates are people with whom one either has or is likely to have direct social contact. They constitute one's "immediate world" (Mitwelt). Contemporaries, on the other hand, are strangers of whom one is aware but who inhabit the farther, anonymous regions of the world of which one has only indirect knowledge. With one's contemporaries one has no immediate social contact. The anonymous contemporaries make up one's "surrounding world" (Umwelt) which is stratified according to levels of anonymity (Schutz and Luckmann 1974:80) - the farther away the strangers live, the less one knows of them and the less one knows, the greater the social distance. With one's con-"sociates" one shares a locality - a spatially defined feeling of belonging, while with one's con-"temporaries" one shares only the fact that they live simultaneously with oneself. One shares the same social time but contemporaries inhabit a distinct, residual region of social space. 
The Bay of Buli is to most people in Waiflí the horizon of their immediate world (Mitwelt; see Map 1), since only relatively few have been as far as Tobelo or Ternate. To the villagers of Waiflí, it is really only the neighbouring Buli and Maba villagers in the bay that are their consociates. The multiplicity of spatial directionals between Cape Lilewi and Cape Ngolopopo expresses this familiarity with their immediate world. The fact that other places within the Halmaheran area are still spatially distinguished by varying locatives reflects a fairly intimate cultural knowledge of these areas. Beyond this known and in cultural terms proximate area, a uni-dimensionality dominates. The world of contemporaries is thus spatially divided into two domains; on the one hand the island of Halmahera outside of the Bay of Buli in which a multi-dimensional spatial grid testifies to its relative social proximity and, on the other hand, the world beyond where only one dimension, the "upward" direction, exists. The importance of the Halmaheran area to Buli, attested to by the variety of locatives, is a manifestation of the political and symbolic importance of the reign of the Ternate and Tidore sultanates which tied this area into a spatially complex but symbolically interpretable world.

The unknown nature of the "upward" direction is repeated and its negative moral qualities opposed in the "downward" direction. Nap refers to a "downward" movement both in the normal vertical sense and the horizontal sense of being a particular direction in social space. It is the direction you take when you walk along the coast from Waiflí to Cape Lilewi on the northeastern point of the peninsula some $110 \mathrm{~km}$ away. Lilewi is as far "downwards" as it is possible to go from Buli and still remain within social space. However, sorogá, the place of the spirits of the dead (smengit) is also said to lie "down below". A riddle (cagulu) plays on this "downward" location of sorogá:

$\begin{array}{lllllll}\text { Cagulu!: } & \text { N-celi puis dunia } i, & n \text {-amtuli mali } & \text { sorogá } i \\ \text { Riddle!: } & \text { 3s-eat } & \text { up world it, } & \text { 3s-sleep in } & \text { sorogá it }\end{array}$

This is a riddle!: he eats "up" in this world and he sleeps in the land of the dead.

The answer to the riddle is: the mangrove crab (kakaróu wat), because the crab is said to hide down in the mud of the mangroves at night from where it preys on small fish that it has to come up to eat. Playfully, the riddle equates the directional opposition between "up" and "down" to that of "this world" and sorogá (the land of the dead). Here then sorogá is placed below/down in a vertical sense - in the mud or in the ground. This vertical notion of down in relation to sorogá is probably associated with burial, a practice which places the deceased closer to his or her final destination, sorogá. Sorogá, however, is "downward" both in a vertical and a horizontal sense. In general, graves are thus oriented in the "downward" direction parallel to the coast. One might say that the vertical plane and the horizontal plane of canonical social space merge 
in the "downward" direction of sorogá. Sorogá is both "underground" and "beyond Cape Lilewi", as one can deduce from other burial practices. In pre-Christian times, before plank coffins began to be used, people were buried in canoes whose ends had been cut off and sealed. In the canoe, plates, knives and cloth were arranged with the corpse for travel to sorogá and the deceased would clutch a small amount of money for the expenses on the way. The canoe would take the deceased to sorogá, placed simultaneously "downward" and "seaward". The only possible exception to a "downward" orientation of the grave is thus a "seaward" orientation. That "down" was somewhere beyond the sea is also evident in the custom that siblings of a newly deceased person would cut down young banana plants and fruit trees from the garden of the deceased and throw them into the stream. The immature plants would drift off (myaling) to sorogá where they would arrive with fully ripened fruits. ${ }^{18}$ Myaling ("to drift away") is used as a general metaphor for the disappearance (amyangis) of something. To float "downstream" (yeli as opposed to solat, upstream) corresponds to the seaward direction (laláu). In order to reach "down to sorogá", the trees must float first "downstream" and "seaward" to a point beyond the sea in the "downward" realm of the dead. To do so the plants must follow the "downward" direction parallel to the coast to Cape Lilewi and then continue this "downward" movement beyond the ordinary borders of social space. Sorogá is, in other words, the spiritual extension of the "downward" direction of socio-mythical space on a vertical as well as a horizontal plane. It opens up at the juncture of the "downward" and the "seaward" directions. The mythical "down" of sorogá, like the unknown "upward" region of space, lies somewhere beyond the sea. The ocean that bends "upwards" to America also bends "downwards" to sorogá.

Many people still think of sorogá as the place of the dead, but the progressive conversion of Buli people to Christianity since 1901 introduced a competing notion: dead Christians go to the heaven of the Christian God, a locality for which the Malay near-homonym surga is used. In contrast to the "downward" direction of the Buli place of the spirits, however, Christian heaven is situated in an "upward" direction in the sky (nais langit). Conversion to Christianity has thus meant a relative transfer of symbolic significance from the "downward" towards the "upward" direction. A parallel displacement towards the "upward" region has happened in the field of political power. Until the first decades of the twentieth century, the two sultanates, Ternate and Tidore, located "on the seaside", were the ruling political sites of North Maluku. Although their actual power was ephemeral and had been constructed as political dominance only as a result of centuries of colonial indirect rule, the sultanates held great symbolic significance for people in the Halmaheran peripheries, a significance they retained even after their formal abolition in 1912. However, with the advent of World War 2, Indonesian Independence and the consistently centralist policies of the 
New Order government since 1967, Buli people have increasingly been made aware that the sultanates have vanished and with them the political significance of the "seaside". Instead, political power is now wielded from the "upward" places of Ambon and Jakarta. Ironically then, Christian conversion over the last ninety years and the late colonial and post-Independence period have signified a symmetrical spatial shift. With Christianity and national administrative centralization, political and divine significance has shifted outside the known, proximate and multi-dimensional world of North Maluku to the unknown, unidimensional domain "up there". The spatio-symbolic world of Halmahera depicted in Figure 4 has thus been increasingly emptied of significance as the mythical and political content of the "downward" and "seaward" directions has been watered down and shifted to the "upward" region outside the Halmaheran realm.

However, as was the case with the Christian displacement, the shift of power to the "upward" region that has accompanied political modernization and national independence is neither completely successful nor unequivocal. Although Tidore has lost much of its former significance, Ternate remains the economic centre of North Maluku, and it is through the town of Ternate that cash crops leave the area and consumer goods arrive. As was the case during sultanate rule, it is today still the "seaside" domain that mediates between Buli and the outside (or, to be precise "upward") world. Politically, the Indonesian nation-state has derived much ideological benefit from portraying the post-Independence administration in North Maluku as a continuation of sultanate rule. Thus, the administrative borders of the two present-day regencies (kabupaten) in Halmahera largely follow the former lines of allegiance to the two sultanates of Ternate and Tidore, and it is often stated that the regent (bupati) has merely replaced the sultan. The reestablishment of these administrative borders was part and parcel of the attempt to use the sultanates, abolished by the Dutch in 1912, as political legitimization for the Indonesian claim to Dutch New Guinea (Irian Jaya). ${ }^{19}$ In 1956 at the height of the Indonesian campaign, Tidore was made the capital of Central Halmahera and the still Dutch-controlled New Guinea. Tidore also functioned as headquarters for the military part of the campaign. The choice of Tidore was politically significant, for the Indonesian claim to Dutch New Guinea rested in the main on the political construction, created and exploited over centuries by the Dutch, that the Sultanate of Tidore through the mediation of the tribute raids that ensued from Central Halmahera had had traditional sovereignty over large parts of Papua. After the Indonesian struggle for political control over Dutch New Guinea had succeeded, Central Halmahera including Buli was made an administrative area in 1967 in a move that effectively recreated the spatial extensions of the Tidore sultanate. Central Halmahera was eventually recognized as a formal regency (a sub-provincial district) in 1990 as part of economic plans to promote and facilitate the exploitation of natural resources (timber and 
minerals, in particular) in the area. The re-establishment was, in addition to being politically successful and economically beneficial to the provincial government, also ideologically effective. Locally in Central Halmahera, the symbolic legitimacy of this political reestablishment of the sultanate borders by far overshadows any critique of the detrimental effects of logging and mining in the area.

\section{Tradition, Modernity and Spatial Involutions}

According to Buli mythology, the power struggles between the sultanates were fought in the Bay of Buli between the two guardians and warriors of Ternate and Tidore: Tobelo and Buli, respectively. The Tobelo population in the area were traditionally, like Buli people themselves, nomads and some Tobelo still retain this mode of existence despite intense pressures from logging and government settlement programmes. These nomads, referred to as Kapat or Gibiyaban in Buli and known to the outside world by the derogatory appellation "Tugutil", are still feared by Buli people for their alleged proclivity to kidnap women and kill men who venture into the forest. Along with dangerous forest spirits the Tobelo nomads make the forest and the "landside" in general a "space of danger". The traditional enmity between Tobelo and Buli is therefore spatially expressed as an opposition between the coast occupied by Buli and the forest (or land) occupied by Tobelo people. The coastal mode of life of Buli people signifies, in turn, a mediating position between the Tobelo warriors of the Ternatan sultanate, on the one hand, and the Tidore sultanate in need of protection, on the other. The "seaside" is, as we saw, the direction of the sultanates of Ternate and Tidore. The exclusive use of a specified spatial direction clearly reflects the symbolic importance of these two sultanates for Buli villagers. The fact that the traditional warriors of the Sultan of Ternate and the enemies of the Buli, the Tobelo forest-dwellers, are associated with the "landside" derives its valency from the opposition to the Sultan of Tidore "on the seaside". Tobelo warriors of the Ternatan Sultanate associated with the dangerous landside are in other words opposed to the Sultan of Tidore, associated with the safe "seaside". ${ }^{20}$ The most important axis in the Buli spatial conception of the world (landside-seaside) is thus used to express what is the essential feature of their cultural identity: their role as bellicose guardians of the "seaward" Tidore Sultanate against the treacherous Tobelo nomads on the "landside". Moral space is in this way simultaneously the inscription of a particular political history and the manifestation of a cultural self-identity.

While the symbolism of the land-sea axis expresses an ideal interpretation of the traditional place of Buli society in the world, the landside also contains within it contradictions that mirror the ambiguous relation of Halmaheran societies to modernity in general and the West in particular. Just as the spatial shifts affecting the "downward" and "seaward" directions speak to changes 
accompanying Christianity, colonialism and Indonesian state centralization, a symbolic linkage between the "landward" and "upward" directions form an incipient interpretation of modernity. Deep inside in the forest, days of hard travel beyond the "Tugutil", an illusory people known as Yawas or more commonly by the North Moluccan Malay term Biri-biri is rumoured to exist. ${ }^{21}$ Biri-biri are mythical white descendants of the Portuguese driven out of North Maluku by the Dutch during their struggle for control of the clove trade in the seventeenth century. They retreated, so the story goes, into the forest where they regressed into an animal state, growing fur and losing the ability to speak and make fire. Now they roam the forest killing wild pig and deer and consume their prey raw. Although they are not an immediate threat - they live far inland and generally avoid outsiders - they belong to the unsettling array of beings associated with the forest and the landside. These descendants of former Western colonialists constitute a curious spatial opposition to the "upward" region in terms of primitivity and modernity.

Buli people are well aware that most important decisions affecting them are decided by the government "up" in Jakarta and Ambon. Little has, in other words, changed from the time of direct colonial rule when the Dutch "up" in Batavia (and ultimately "up" in Holland) ruled the island. "Up" is, however, not just the site of political power, it is also the region from where the Indonesian government promises great things will come. The ideological emphasis on the benefits of development and modernity thus has a spatial location, seen from a Buli perspective. Modernity is the movement of things from "up" there to "down" here. The "upward" region is the advanced, modern domain of high technology, cars and riches and at the village level these objects are seen as the quintessential trappings of Western society. Whereas Westerners (Orang Barat) "up there" represent the goal of economic ambitions, one particular type of degenerate Westerner also inhabits the interior of the landside. These animal-like creatures belong to the proto-typical mythic time known as "the Portuguese era" (jaman Portugis). They are a contemporary manifestation of the mythic past, dwelling in the recesses of the space of danger that the "landside" represents. White people are, in other words, located in two dramatically different domains, each domain associated with a particular slice of time. They are found on the dangerous "landside", the only remaining creatures of a "long-ago". As living descendants of a colonial history, Biri-biri represent the ultimately "primitive" and "backward" (labels often tagged on Halmaheran villagers by more "aware" government officials). These Western descendants are both in evolutionary and historical terms at the point of origin. But Westerners also inhabit the unknown "upward" region of social space, a region that represents an equally mythic political promise of a millenarian economic future. ${ }^{22}$ The political millenarianism surrounding "development" in political discourse is given further direction by Halmaherans, many of whom witnessed the affluence and lavishness of American 
and Australian soldiers at the end of World War 2. The development programmes of the government seem naturally to promise the West as the goal of economic progress. The relation to the West is, in this sense, truly mythic: Westerners are in spatiotemporal terms both the point of origin and the intended destination.

To sum up, one could say that space in Buli conceals simultaneously a mythological reality and a political history. The immense changes which Buli, along with other North Malukans, have experienced since the arrival of the first Europeans in 1511 have all found a place within the same spatial arrangement. The spatial universe of Buli accommodates a multitude of effects of these political changes in the main spatial realms of the "seaside" and the "landside", the "above" and the "below", the "inside" and the "outside". Space is inherently heterogeneous, and distinctions in space become meaningful only in relation to their mythical content and the values associated with the various spatial regions. Michel Foucault (1986) has coined the term "heterotopia" to describe spaces within the social world that are set apart and are made to function as fields for a particular kind of power relations that also penetrate the space not marked as different. $^{23}$ In Buli the canonical fixed extensions of space are heterotopic in this sense. The sultanates "on the seaside", sorogá "downward", Tobelo nomads "landward", the (modern) world "upward" and Patani "out there": each represents a specific difference in relation to Buli society. Each of the heterotopias is a complete place unto itself, located in a specific region of space to which it gives meaning. The heterotopias are not free-floating signifiers, however. They orient themselves towards and draw their significance from their relation to specific aspects of Buli life. Waiflí is itself a heterotopia of sorts, because the village is the highest (most "upward") place within the proximate, known world of Halmahera. It is, in a sense, the logical, if not actual, jumping-off point for travel into the unknown "upward" region.

The relations between the heterotopias and Buli are expressions of everchanging and sometimes contradictory power relations. Each heterotopia thus has a history; each responds to specific changes that have taken place in Buli, the topia to which they all constantly re-orient themselves. Space, in this sense, is not another dimension from, or at an angle to, time. In space, rather, time and social change are organized into meaningful difference. Simultaneously expressing change and condensation, space, at this level, presupposes and takes for granted cultural identity. Spatial heterotopias set up the contours of a "cultural identity" by establishing Buli as the conventional point of reference for a spatial view of the world: "for all us who speak Buli the world extends like this!" Through the symbolic installation and moral maintenance of heterotopias, spatial deixis establishes "locality" in Appadurai's sense of the word as a "structured sense of belonging". This spatial view of the world is itself a condensation of the changing heterotopias of the past. Inevitably out of sync, it is from this condensation, a spatial type of "mythic reality" (Sahlins 1985), 
that the present is engaged. Ironically, it is by virtue of being out of sync that the power structures of the present are made to seem legitimate and tolerable. The regent appointed by the central government is invested with the same kind of authority that the Dutch-installed sultan had in the past. At the same time, the spatial shifts of political power have highlighted how North Maluku, in former times both prominent in the European imagination as the Spice Islands and crucial as an economic centre in the Malay archipelago, has been increasingly marginalized. Now power has shifted irreversibly to the unknown "upward" realm of space as Buli people struggle to find new means of differentiating and understanding the peoples of this residual realm of space.

\section{Conclusion}

The omnipresence of spatial deixis in language, a common trait of most Austronesian languages, functions in two, seemingly contradictory, ways in Buli. At the level of practical orientation, spatial references are relative to the individual speaker. At this level, people take their co-ordinates with them wherever they go within a differentiated matrix of space. It is the differentials of location between speaker and listener, conceptualized within the shared space of the dialogue situation, that make orientation possible. In the heterotopias of the Buli world we see, however, the construction of a set of canonical, fixed topoi: Tidore is "to the seaside" of Buli and America is "upwards". Rather than contradicting the relative space of practical orientation, the conventionality of these heterotopias is the effect of a different dialogue situation. Instead of differing in their spatial location, as the speaker and the owner of the knife did, two Buli interlocutors speaking about Tidore share the same location in a spatially differentiated, conventional layout of the world beyond Buli. In the spatial reference of this dialogue situation, the common location implies a shared spatio-cultural identity. The same spatio-grammatical vocabulary that serves to orient Buli owners and borrowers of knives in this way functions to assert their common cultural identity and history when the topic of conversation is Tidore or America. The two "levels" that I initially distinguished are therefore not opposed: in referring to space in daily discourse, "locative" subjectivity and a cultural "locality" are established by the same linguistic processes. Locative subjectivity and cultural locality are analogous aspects of the same spatial representations of the world, each giving meaning and value to the other.

To put it plainly, language needs to refer to space constantly, and this constant reference creates the contours of two very different but connected entities: "selfhood" and "cultural identity". In Buli deixis one finds a "spatial poesis" in the original sense of the Greek word poiein, "to create or generate". In making use of space and in talking about it, Buli people generate a spatial view of the world that defines its moral, social and practical potential. Whether necessary 
or accidental, notions of both subjective and cultural identity are therefore constructed, at least in part, through the reference to space in language.

\section{References}

Adelaar, K. Alexander

1997 An exploration of directional systems in West Indonesia and Madagascar. In Gunther Senft (ed.) Referring to space: studies in Austronesian and Papuan languages. Oxford: Oxford University Press.

Appadurai, A.

1995 The production of locality. In R. Fardon (ed.) Counterworks: managing the diversity of knowledge, pp.204-225. London: Routledge.

Barnes, R.

1974 Kédang: a study of the collective thought of an Eastern Indonesian people. Oxford: Clarendon Press.

1985 Tanebar-Evav and Ema: variation within the Eastern Indonesian field of study. JASO 16(3):209-224.

1986 Concepts of space. Man 21(4):742-743.

1988 Moving and staying space in the Malay archipelago. In D. Moyer and H. Claessen (eds) Time past, time present, time future: essays in honour of P.E. de Josselin de Jong, pp.101-116. Verhandelingen van het Koninklijk Instituut voor Taal-, Land- en Volkenkunde, No. 131. Dordrecht: Foris Publications.

1993 Everyday space: some considerations on the representation and use of space in Indonesia. In J. Wassmann and P. Dasen (eds) Alltagswissen. Der kognitive ansatz im interdisziplinären dialog (Everyday cognition. Interdisciplinary perspectives). Freiburg: Universitätsverlag Freiburg.

Barraud, C.

1979 Tanebar-Evav: Une société de maisons tournée vers le large. Cambridge: Cambridge University Press.

Benveniste, E.

1966 De la subjectivité dans le langage. In Problèmes de linguistique générale, pp.258-266. Paris: Gallimard.

Bourdieu, $\mathrm{P}$.

1977 Outline of a theory of practice. Cambridge: Cambridge University Press.

Bühler, K. 
1982[1934] The deictic field of language and deictic words. In R. Jarvella and W. Klein (eds) Speech, place, and action: studies in deixis and related topics. Chichester: John Wiley and Sons.

Covarrubias, Miguel

1937 Island of Bali. New York: Knopf.

Downs, R. and D. Stea

1977 Maps in minds: reflections on cognitive mapping. New York: Harper and Row.

Fillmore, C.

1982 Towards a descriptive framework for spatial deixis. In R. Jarvella and W. Klein (eds) Speech, place, and action: studies in deixis and related topics. Chichester: John Wiley and Sons.

Firth, R.

1970 Postures and gestures of respect. In J. Pouillon and P. Maranda (eds) Echanges et communications: mélanges offerts àClaude Lévi-Strauss. The Hague: Mouton.

Foucault, M.

1986 Of other spaces. Diacritics 16(1):22-27.

Fox, J.J.

1973 On bad death and the left hand: a study of Roti symbolic inversion. In R. Needham (ed.) Right and left: essays on dual symbolic classification, pp.342-368. Chicago: The University of Chicago Press.

Gell, A.

1985 How to read a map: remarks on the practical logic of navigation. Man 20:271-286.

1986 Reply. Man 21:344-346.

Gladwin, T.

1970 East is a big bird: navigation and logic on Puluwat Atoll. Cambridge, MA: Harvard University Press.

Gupta, A. and J. Ferguson

1992 Beyond "culture": space, identity, and the politics of difference. Cultural Anthropology 7(1):6-23.

Hallpike, C.

1979 Space. In The foundations of primitive thought, pp.280-339. Oxford: Clarendon Press. 
1986 Maps and wayfinding. Man 21:342-343.

Haugen, E.

1957 The semantics of Icelandic orientation. Word 13:447-459.

Heidegger, M.

1962 Being and time. Oxford: Blackwell.

Hobart, M.

1978 The path of the soul: the legitimacy of nature in Balinese conceptions of space. In G.B. Milner (ed.) Natural symbols in South East Asia, pp.528. London: School of Oriental and African Studies.

Hueting, A.

1922 De Tobeloreezen in hun Denken en Doen (Tweede Gedeelte). Bijdragen tot de Taal-, Land-en Volkenkunde 78:137-342. The Hague: 's-Gravenhage.

Jensen, A.

1947-48 Wettkampf-Parteien, Zweiklassen-Systeme und geografische Orientierung. Studium Generale 1:38-48.

Kristeva, J.

1989 Language: the unknown: an initiation into linguistics. New York: Columbia University Press.

Lyons, J.

1982 Deixis and subjectivity: loquor, ergo sum? In R. Jarvella and W. Klein (eds) Speech, place, and action: studies in deixis and related topics. Chichester: John Wiley and Sons.

Maan, G.

1940 Boelisch-Nederlandsche woordenlijst met Nederlandsch-Boelisch register. Verhandelingen van het Koninklijk Bataviaasch Genootschap van Kunsten en Wetenschappen 74, Derde Stuk. Bandung.

1951 Proeve van een bulisch spraakkunst. Verhandelingen van het Koninklijk Instituut voor Taal-, Land- en Volkenkunde 10. The Hague: 's-Gravenhage.

Merleau-Ponty, M.

1962 Phenomenology of perception. London: Routledge.

Pick, H. and L. Acredolo (eds)

1983 Spatial orientation: theory, research and application. New York: Plenum. Platenkamp, J. 
1988 Tobelo. Ideas and values of a North Moluccan society. PhD thesis. University of Leiden.

Sahlins, M.

1985 Islands of history. Chicago: The University of Chicago Press.

Schutz, A.

1967 The phenomenology of the social world. Evanston, IL: Northwestern University Press.

Schutz, A. and T. Luckmann

1974 The structures of the life-world (vol. 1). London: Heinemann.

Shelden, D.

1991 Setting a course in Galela: an orientation system of North Halmahera. In T. Dutton (ed.) Papers in Papuan linguistics No. 1 (Pacific Linguistics series A-73). Canberra: Department of Linguistics, Research School of Pacific Studies, The Australian National University.

Taussig, M.

1987 Shamanism, colonialism, and the wild man: a study in terror and healing. Chicago: The University of Chicago Press.

Taylor, $\mathrm{P}$.

1984 Tobelorese deixis. Anthropological Linguistics 26(1):102-122.

Teljeur, D.

1983 Spatial orientation among the Gimán of South Halmahera. In E. Masinambow (ed.) Halmahera dan Raja Ampat sebagai Kesatuan Majemuk. Studi-studi terhadap suatu Daerah Transisi. Buletin Leknas, vol. 2. Terbitan Khusus. Jakarta: Lembaga Ilmu Pengetahuan Indonesia.

Yoshida, S.

1980 Folk orientation in Halmahera with special reference to insular Southeast Asia. In N. Ishige (ed.) The Galela of Halmahera: a preliminary survey. Senri Ethnological Studies No. 7. Osaka: National Museum of Ethnology.

\section{Notes}

l I have benefited greatly from readings of this paper in its various stages of completion by Professor James Fox, Dr Michael Young, Dr Penny Graham, Vibeke Asmussen, Andreas Roepsdorff and Dr Poul Pedersen. The ethnographic material was collected during fieldwork in Indonesia between 1991 and 1993. I would like to thank the Indonesian Academy of Sciences (LIPI) and Pattimura University in Ambon for their co-operation and kind assistance during this period.

2 The usual definitions of deixis underscore this relation between speaker, enunciation and place. Julia Kristeva, for instance, defines deixis as "all the words that situate and indicate the act of enunciation and are intelligible only in relation to it" (1989:334). 
3 The contextual quality to deictic words entails only apparent contradiction. As Barnes rightly points out "[t]heir application in an immediate context may seem inconsistent with their use in another, but this is because reference points change" (1974:83). The deictic words that indicate spatial direction are therefore "truly abstract terms for ordering space" (1974).

4 The literature on orientational systems is enormous and the subject of folk orientation has been of seemingly inexhaustible interest to academics since Haugen's founding article on Icelandic orientation (1957). A preliminary and by no means representative list of references, including both general theoretical works and analyses of local Austronesian systems, might contain: Covarrubias (1937); Jensen (1947-48); Gladwin (1970); Fox (1973); Downs and Stea (1977); Hobart (1978); Pick and Acredolo (1983).

5 For the sake of simplicity I use the locative form here, indicated by the prefix po-. As we shall see later, different types of directionals are formed from the root of the locative word by adding other prefixes.

6 For instance, the name of the village Waiflí means "Place (-li ) of the Sagobark Pail (waif)".

7 In the Buli language word stress is usually but not always on the penultimate syllable. I use the acute accent to indicate stress if it is not on the penultimate syllable. Thus, mali (with stress on the last syllable) is distinct from mali (where the word stress is on the usual penultimate syllable). Whereas mali is a directional term with the meaning "towards here", mali is a preposition, meaning "in", "on", "at", "from". Mali Tobelo for instance means "in or from Tobelo". Accordingly, the sentence mali au mali means "from you towards here/to me".

8 The cognitive implications of this type of orientation have been the subject of some debate (Barnes 1988, 1993; Gell 1985, 1986; Hallpike 1979, 1986). The debate still stands, somewhat acrimoniously (see Hallpike 1986), between whether "primitive" peoples have totally different, less abstract, ways of perceiving space (Hallpike 1979) or whether we are all — "primitive" and "civilized" —in fact Cartesian and Euclidean in regard to space (Gell 1985). In my view the problem with this debate is that it regards cultural differences of spatial articulation as fundamentally cognitive rather than based on differences in discursive and social practice (see also Barnes 1988:106). Cognitive exoticism or universal "non-token-indexical" Cartesianism seems to me a poor and unnecessary choice.

9 See also Barnes (1988) for a critique of the academic tendency to invoke the figure of the rational Westerner when describing cultural differences in spatial orientation.

10 Benveniste writes: subjectivity is

the emergence into being of a fundamental property of language. "Ego" is he who says "ego". Here we find the basis of the "subjectivity" which is determined by the linguistic status of the "person" ... [l]anguage is only possible because each speaker sets himself up as a "subject" by referring to himself as "I" when he speaks (1966:260, my translation, emphasis in original).

11 The founding text by Karl Bühler on the subject of deixis is the second part of his general book on language theory from 1934. Sections from this second part of the book were translated and reprinted in 1982 under the title The deictic field of language and deictic words. The text probably remains the most important on the subject of deixis.

12 Although the origo or zero-point of deixis is ultimately ego-centric in Buli as in any language (Lyons 1982:121), the Buli conception of space is not ego-centric. It is indeed one's position in space that determines how one's world pans out from the origo, but the spatial directions in a given place are always the same and remain the same whether one is there or not.

13 This conception of space is topomnestic in Bühler's sense (1982:27), a type of deictic orientation in which the emphasis is on the necessity of orienting oneself within a shared space. Of course, use of the compass also depends on topomnestic space, in the sense that everybody needs to believe in the authority of the shared spatial conditions set up by the compass and be able to project themselves into its privileged viewpoints. The difference is, of course, that Buli language in daily social practice does not allow any privileged sites or viewpoints. It insists rather on the relevance of every given site of enunciation. The listener needs to be able to project him- or herself into the position of the speaker in every speech situation that takes on its deictic character (its actual spatial layout) as a result of its present location in space, not because of such set parameters as cardinal points.

14 In every act of speaking, deixis demands, as Fillmore puts it, that the speaker "implicitly takes his or her own body, or that of his interlocutor as a 'deictic centre"' (1982:37).

${ }^{15}$ The universal bodily basis for the perceptions of space is what prevents a radically relativist position on the question of subjectivity. Although subjectivity is related to language and deictic perceptions of space, linguistic representations of space are grounded in embodied spatial perception. The deictic 
systems of other languages are not as foreign to ours as they may seem at first blush because of this corporeal experience of space (Bühler 1982:26).

16 I do not wish to claim that Buli locative subjectivity is ontologically singular. Different as the spatial dimensions of this universe may seem from a Western point of view, they are by no means unique among Austronesian societies. In fact, there is among Austronesian societies a structural similarity in their spatial systems that transcends the otherwise great cultural and social variation among these societies (Barnes 1988:113). Therefore, it is not surprising that Buli people easily translate local spatial terms into North Moluccan Malay. North Moluccan Malay is a regional dialect with long historical roots in Maluku which is closely related to the standard Indonesian language. The North Moluccan Malay spatial equivalents are used on a daily basis in communication with non-Buli speakers in neighbouring villages. Most of these non-Buli speakers are people from other parts of Halmahera with similar systems of spatial orientation. The increased incidence of bilingualism and language shift associated with the introduction of national education and electronic media therefore do not seriously affect the outlines of the spatial schema.

17 One interesting exception to this equation of the "upward" direction with territories outside sultanate rule is the southern tip of Halmahera and the islands of Kayoa and Bacan, all of which are designated as "upwards". These areas were under the rule of the Sultan of Ternate. This also includes Bacan which was originally a separate sultanate but which effectively came under Ternatean rule in the sixteenth century. Buli people would have had little knowledge of and contact with these areas, not only because of political enmity but also due to the logistics of sea travel around Halmahera. The combination of favourable winds and higher population density has favoured travel north around the island. The relative Buli ignorance of these "upward" southern areas of Halmahera still holds today. Contact with the economic centre of Ternate is almost exclusively mediated north around Halmahera through the fast-growing town of Tobelo, rather than around the southern tip of the island. The combined social distance in terms of economy, cultural knowledge and political allegiance probably accounts for the allocation of these South Halmaheran areas as "upward" along with other distant places.

18 One friend and informant claimed that this reversal from old to new in sorogá occurs with all things that we humans throw away or lose. As objects decompose or disappear from our world, they appear as new in sorogá. The destruction of the valuables of a deceased was also practised in pre-Christian times among the Tobelo of North Halmahera, although the notion of renewal has not been mentioned as part of the motivation for doing so (Hueting 1922:142; Platenkamp 1988:154).

19 After Indonesia formally gained independence in 1949, Holland maintained control over the western half of Papua, known as West Papua to the supporters of OPM, the still active resistance movement against Indonesian rule. In the mid-1950s Sukarno intensified his claims to the area as part of his expansionist campaign for an Indonesia "from Sabang to Merauke". Military clashes ensued for several years until Holland in response to US-led pressure through the UN Security Council agreed to give up the area. A care-taking force from the UN temporarily took over control before handing it over to the Indonesian army in May 1963. According to the agreement of transferral, free elections by 1969 were to determine whether West Papua was to become independent or remain as part of Indonesia. In 1969, in an orchestrated election in which only 1025 selected "representatives" of the population participated, it was decided to remain as part of Indonesia.

20 In this context it is unimportant that Ternate is also located "on the seaside", for in Buli the only manifestation of this sultanate was the attacks on hunters and travellers by its forest-dwelling Tobelo warriors.

21 This rumour is not only circulating amongst villagers. Based upon data from the provincial Department of Social Affairs, the 1987 regency census estimated the size of the Biri-biri population to be an outrageous 2,116! At the beginning of my fieldwork the regency head, Dr Bahar Andili, urged me to investigate this population, because of the handful of Western anthropologists who had conducted fieldwork on Halmahera during the 1980s, nobody had obtained satisfactory information on this group.

22 The millenarian character of the political promise for a better economic future ensues from the mantra-like ring to the word "development" (pembangunan) in political discourse in Indonesia. With certain political reservations, the technocrats in the Indonesian government have embraced a conception of economic progress that largely and implicitly has the West as a model. Therefore the millenarian character of the relation to the "West" arises not from any millennial expectations peculiar to Buli or Halmahera but from an attitude of the New Order government that might well be termed a "third-world cult of the modern" (Taussig 1987:278). 
${ }^{23}$ Foucault's examples of heterotopias include prisons, hospitals, cemeteries, theatres, museums, brothels and colonies. In Western society they are all "other spaces" for particular kinds of disciplinary power that contain the internal "other" within a wider space of normalcy. 



\title{
Chapter 9. From the Poetics of Place to the Politics of Space: Redefining Cultural Landscapes on Damer, Maluku Tenggara $^{1}$
}

\author{
Sandra Pannell
}

\section{Introduction}

For a number of years, the people of Amaya and Wulur, two villages respectively situated on the western and eastern coast of the island of Damer, have been locked in dispute over the line demarcating their adjoining territorial domains. Soon after my arrival (in 1986) this altercation reached one of the many climaxes in what has become a major struggle over the appropriateness and appropriation of certain forms of knowledge. Redefining the cultural landscape on Damer amounts to more than just shifting the position of boundaries. It shakes the very foundations of social identity, engendering as it does tectonic epistemological movements. As this idiom suggests, these social tremors have a spatial locus.

In his writing on spatial practices, Michel de Certeau (1984) finds it useful to distinguish place from space. Place, according to de Certeau, refers to the locational instantiation of what is considered to be customary, proper and even pre-established. Space, on the other hand, has none of this stability but instead is composed of the "intersections of mobile elements" (1984:117) which are ambiguous and often in conflict. In short, space is produced when place is risked or activated in practice. Space, as de Certeau points out, is thus "practiced place" (p.117). This distinction between place and space is analogous to the distinction between a map and an itinerary. One signifies the collective and ordered representations of the state of knowledge about the world, the other represents the actions or practices by which this knowledge is produced, affirmed or transformed. As a cultural geography, the landscape is both map and itinerary, place and space. This distinction between space and place, between itinerary and map, constitutes a useful heuristic device in understanding the redefinition of cultural landscapes on the island of Damer in eastern Indonesia.

In this paper, I explore the discursive practices that transform places into spaces and spaces into places. Stories, I argue, are instrumental in this play of changing relationships. On the one hand, they present in synoptic form the physical landscape as a cultural, and thus symbolic, geography; in this capacity they can be regarded as "models of reality" (see Geertz 1973:93-94). On the other 
hand, stories also labour to create what de Certeau refers to as geographies or "theatres of action" (1984:123) and, in this sense, they can be viewed as "models for reality" (see Geertz 1973:93-94). However, more than just reproducing and preserving what is perceived as already given, stories as forms of the "productive imagination" (Ricoeur 1986:xxx) also pave the way for an exploration of the possible and of the possibility of change. ${ }^{2}$ A consideration of the social redefinition of culturally constituted spatial boundaries on Damer highlights this dialectic between the pre-figured and the transfigured and points to the creative, conflictive and changing nature of the relationship between people, place, space and stories.

\section{The Poetics of Place: Constructing Maps}

In Amaya, narratives associated with the different uma ("house") groups represented in the village constitute one way in which knowledge of the landscape is constructed, disseminated and transmitted through time. More than just articulating the sum of this knowledge, Mayawo ("the people of Amaya") stories define and give form to a specific cultural landscape; a landscape criss-crossed by a multitude of significant pathways and punctuated with a number of noumenally important places. As such, it is more appropriate to speak of Mayawo narratives as "topostories" rather than as "histories". 3

Collectively, these pathways and named places signify the journeys taken by a number of anthropomorphic beings (the majority of which are regarded as allocthons, that is, they originated elsewhere) and the sites at which they stopped and performed acts of creation, transformation or destruction. The toponymic activities of these beings establish and authorize their status as other than human; humans are born into a world of ordered named places. They are not considered to possess the power to create places through the act of naming. The unique journeys of each of the beings and the places where they stopped serve to define a number of discrete topographic estates, which today are linked to the different "houses" in Amaya. Insofar as these topographic estates are encoded in narrative form, and given the constitutive importance of place to the identity of an uma, we can speak of local narratives as representing the "origin" stories for a particular "house". In a broader sense, the activities of the beings also served to establish the domains of the different village-centred groups on the island. Domain here is understood as extending beyond the terrestrial limitations of the island and thus incorporates the surrounding reefs, waters and off-shore islands. On this basis, the people of Amaya claim ownership of the western half of the island and associated reefs, of the coral atolls of Nus Leur approximately $25 \mathrm{~km}$ south-west of Amaya, and of the island of Terbang Utara situated some $10 \mathrm{~km}$ south of Damer. Terbang Selatan, the other island in this group, is contentiously claimed by people in the villages of Wulur and Kehli. The eastern half of Damer is variously divided between the seven other villages on the island. In the case 
of these other domains, ownership is again authenticated by the so-called "origin" narratives pertaining to each of these village-centred groups.

The landscape is thus culturally constructed and socially considered as a given; a pre-established, pre-figured order of territorial domains, localized estates and named places linked by identifiable tracks, immutably fixed in time and space. The landscape also serves as the empirical foundation for the veracity of Mayawo stories in the same way that the narratives establish the authenticity of the cultural geography - a recursive movement which inextricably links stories to the landscape, not merely as objects of knowledge, but as forms of knowing or epistemology. Considered as collective representations of what are regarded a priori as established orders of heterogeneous places, stories and the landscape constitute maps, they encode or embed that which is perceived as customary and cultural.

\section{The Politics of Space}

\section{Itineraries}

Mayawo narratives do more than just provide a model or map for understanding place - they also create itineraries or social ways of moving through this spatial and cultural landscape. In this sense, they can be viewed as travel stories and insofar as they are collective cultural representations, they can also be spoken of as, to borrow de Certeau's phrase, the "means of mass transportation" (1984:115). Not only do these narratives detail the adventures and wanderings of a number of different anthropomorphic beings but they also produce geographies of action for people in Amaya. The landscape, as a narrated and geographic text, thus signposts forms of social behaviour, rights, responsibilities and relations. The configuration of places, tracks and land which comprise a "house" estate and of the ancestral associations it has, for example, suggests who is associated with it, the nature of that association and its relational implications, plus the kinds of actions or codes of conduct appropriate in that context.

Thus, the poesis or creation of place which Mayawo narratives effect and recall is simultaneously a construction of social identity and social relatedness. Genealogies of place are also topogenies of people. Affiliation with place or with configurations of places represents more than just an adjunct to the anthropologically constructed social staples of kinship (primarily defined in terms of biological and genealogical relations) and social organization (so often predicated upon the notions of descent and marriage). In Amaya, identification with place(s) invests people with a number of meaningful social identities and constitutes the basis for understanding both social relatedness and the formation of social groups. ${ }^{4}$ For example, individuals born outside of the village and in the surrounding forests are named after the place of their birth. Given the 
associations between named places, estates and the social groups called uma, this name cogently signifies the uma affiliation of the individual as well as pointing to the people with whom he/she shares a common identity. More frequently, however, birth takes place within the context of the village. In this case, the place where a person is born is denoted by the incorporation of the name of an uma into a person's name. The names of uma or "houses" semantically encode and delineate certain constellations of places within the context of the village and metonymically point to the estates associated with each of the uma. Uma is thus a spatial construct which, in terms of one of its significations, refers to a physical residence or house. As I mentioned before, uma also signifies a group of people who participate in a shared identity on the basis of a common identification with one or more of a number of places which collectively comprise the discrete topogeny of an uma. This common affiliation to place(s), and thus "house", is primarily established by birth although there are other means, such as residence, by which an individual can establish a socially meaningful connection to place, to uma. Individuals also differentially identify with more inclusive groups termed ono. The four named ono in Amaya signify the four primary spatial divisions recognized in the village. Recruitment to an ono is informed by a person's identification with place and is mediated by a person's "house" affiliation which serves to signify this link. For instance, an individual is a member of Ono Atowcheyeni on the basis that he/she resides within the area associated with this ono, which in this case encompasses the land fronting onto the sea. Residence in this part of the village is structured by a person's "house" affiliation, "house" identity being inextricably embedded in place. Finally, the name of the village itself confers upon a person his/her most inclusive place-based social identity. This identity is grounded not only in the village as place but also signifies all of the places which collectively comprise the cultural landscape as a shared experience. Identification with place thus constitutes the basis for the construction of social relatedness (which may be expressed in a number of idioms including place, biological substance and genealogical propinquity) and, in this sense, expressions of identity and relatedness should be viewed as spatial practices. Thus place, in this understanding, not only has a noetic or knowledge-based value but also carries with it what Corbin (1969) calls an "imaginal" value in that it is constitutive of the fundamental ground of social reality.

It is this engagement of place, or the "practice of place", which produces what de Certeau defines as space: the social geography. Space is thus the actualization, by the operations of historical subjects, of what has already been created - place. This engagement of place not only produces space but also reproduces the conceptual ground which informs these practices; the so-called "structures of the long run", to borrow Marshall Sahlins's phrase (1981:9). However, as Sahlins points out, cultural categories are not merely reproduced, 
their reproduction also affects their transformation. In this respect then, space as realized place is analogous to Sahlins's notion of the "structure of the conjuncture", and as such is already a politicized domain. The politics of space are particularly well illustrated in relation to the marking out and maintenance of boundaries on Damer.

\section{Boundaries}

Returning to the dispute between the villages of Amaya and Wulur: this dispute concerns the position of the boundary between the domains of the two villages. The place presents a paradox; it is the point of difference between the two villages yet it also represents what they have in common. And what they share is the narrative that recounts the actions by which the boundary separating the two regions was established. This narrative constitutes the "origin story", or topogeny, with different emphases for the "house" of Newnuny in Amaya and for the "house" of Rohmode in Wulur. These narratives clearly articulate or, put differently, set in place the position of the boundary between the two territories. The empirical mark of this boundary is a river that separates the two beach sites of Odaro and Parano, respectively located in the domains of Amaya and Wulur. The river, flowing as it does into the sea, also cuts between the two islands of Terbang Utara and Terbang Selatan, so that Terbang Utara falls within the domain claimed by Amaya while Terbang Selatan is incorporated into the region owned by the residents of Wulur.

Notwithstanding their shared traditions and the empirical evidence which verifies the truth value of local narratives, people in Wulur assert that the boundary lies further west than that delineated in the narrative. By extension this assertion implies that they can also legitimately (in terms of the logic of the narrative, that is) claim the island of Terbang Utara as their own.

There is an economic logic which informs these claims. The reefs surrounding both Terbang Utara and Terbang Selatan are, or in the latter case were, rich with trochus shell. Having largely exhausted the trochus shell reserves on their own island, and spurred on by the high prices offered by the local Indonesian-Chinese traders, many people in Wulur have now taken to "stealing" the shell from the reefs surrounding Terbang Utara, the island claimed by the residents of Amaya. A paucity of appropriate resources and technology prevents people in Amaya from maintaining a constant surveillance of their island territory. While disturbed and frustrated by the actions of people in Wulur, Mayawo nevertheless do not regard the defence of their territorial integrity as a matter of economic concern or imperative; the coastal and terrestrial area claimed by Amaya is easily twice that owned by Wulur. Rather, it is for them a matter of cosmological and ontological importance. 
In 1986, armed with the resolve to end the dispute once and for all (and with spears, bows and arrows) the people of Amaya travelled to Wulur. The dispute, for them, would be resolved in terms of its own logic - that is, in terms of the dictates of "tradition" (adat), grounded as it is in local narratives and the cultural geography. In order to do this, according to local adat, the parties concerned are required to drink locally brewed palm spirit (arko) together. Apparently, in this context, the brew has the capacity to distinguish right from wrong, truth from fiction. The offenders identified in this way are immediately struck down and die a rather painful death. People in Wulur declined to participate in this ceremony. Their refusal resulted in a declaration of war by the residents of Amaya. The situation became so inflamed that the police were called in from the neighbouring island of Kisar, supposedly to control hostilities.

The two men who arrived by motor launch were reluctant to take sides and, after half-heartedly threatening the warring parties with imprisonment if they did not desist with hostilities, quickly departed. The outcome of this official intervention? The people of Amaya returned to the other side of the island, the position of the boundary is still in dispute, the residents of both villages continue to menace each other albeit from afar, and the island of Terbang Utara continues to be visited on a regular basis by the inhabitants of Wulur for the express purpose of poaching trochus shell.

So what are we to make of this incident? It is apparent that local narratives signify different things for different people. These different significations are actively created by the operation of a number of social processes which variously function to fragment, reduce and dilute the status of these stories (de Certeau 1984:125). By this I mean that the stories become fragmented through their application in a range of diversified social contexts in which there are a number of different and alternative authoritative references. The "excommunication" of ancestral figures, the deconsecration of place, and the construction and extension of neutral areas devoid of the traces of ancestral actions further serves to fragment the narratives. The reduction or miniaturization of the significance of these stories to the point where they apply to only a small group, or at most to one village, further influences their transportability and social import. Finally, the inclusion of other stories within the framework of local narratives gives these narratives a polyvalent status so that their significance changes according to the identity of the groups in which they circulate.

In terms of the dispute, this means that the police (and the local traders) dismiss these narratives as curious and somewhat fantastic fictions, the significance of which pertains only to the level of the village. Their actions are informed by other discourses, namely those tied up with, and empowered by, the state and the market-place. For the local traders and the police the landscape is not imbued with the noumenal, toponymic activities of the ancestors. Rather, 
it is excommunicated from these associations, deconsecrated of its cultural meanings and generally neutralized in the process of constructing it firstly as an economic resource and secondly as an administrative area.

The residents of Wulur, however, are caught between the logic of local narratives and the seduction of national and economic myths. Constructed as a commodity, and a recent one at that, trochus shell is not seen to fall within the province of objects encompassed and controlled by local narratives. Trochus shell as a commodity is thus not regarded by Wulur residents as an adat-defined thing. The implication of this is that the meaning of the landscape as an economic entity is increasingly emphasized above and beyond its other meanings in terms of identity, relatedness and cosmology. The imperative to disassociate objects and adat in this way and, by extension, people and place, is largely provided by the commodity context on Damer, which is primarily structured by the Indonesian-Chinese traders and their actions. In this connection Wulur is both home and headquarters for their activities and, in the light of this, it is not surprising that the commodity context is most acutely accentuated in this village.

The assertion by people in Wulur, however, that the boundary between the domains of Wulur and Amaya lies elsewhere clearly points to the fact that the value of local narrative has not been totally dismissed and, indeed, suggests an engagement, albeit selective, of these very narratives. What appears to have happened, though, is that in their argument with the residents of Amaya, people in Wulur have miniaturized the significance of the narrative so that it only relates to the particular group in Wulur for whom the narrative represents a founding "topostory" and they have chosen instead to valorize other narratives. In Amaya, the opposite of this has occurred. To some extent, this process of reduction can be understood in terms of the heterogeneity of the population of Wulur. Wulur, perhaps more than any other village on the island, is home to a large number of immigrants (pendatang) who originate elsewhere in the region. For these people local narratives of place and the cultural geography itself do not hold the same meanings as they do for indigenous residents. In the context of the boundary dispute, however, indigenous residents would seem to have selectively chosen to distance themselves from their collective memories - a form of social amnesia perhaps.

The appropriation and appropriateness of narrative for authorizing social action is thus contextual. This is clearly demonstrated in the dispute between Wulur and the village of Kehli over the ownership of Terbang Selatan. In this case, the residents of Kehli claim ownership on the basis of long-term residence on, and association with, the island. The inhabitants of Wulur, however, emphasize the inalienability of their attachment to the island by citing the same narrative which they choose to play down, even forget, in their argument with Amaya. It would seem then that where other authorizing references exist that 
best suit the situation and interests of those concerned, local narratives are deemphasized in terms of their function as spatial legislation. The assertions of Wulur residents regarding the "true" position of the boundary, assertions motivated by the desire to maximize their economic interests, suggests that this is exactly what has happened. The legislative effectiveness of these other discourses is perhaps best demonstrated by the fact that Wulur residents continue to poach trochus shell.

The people of Amaya are the "true believers" in this context. Local narratives are more than "just so" stories and, notwithstanding the thrust of Christianity and Indonesian nationalism, they still represent the primary epistemological forms by which place is engaged in the production of social identity and in the reproduction of a theory of practice. In the context of their dispute with Wulur, they resist the processes of fragmentation and miniaturization, and work to maintain the univalent (and universal) status of their stories. The position adopted by immigrants in Amaya is thus quite different from the one advocated by pendatang in Wulur. In the former case, it is in people's interest to support and, indeed, memorize, the content and meaning of local narratives. In doing so, they firmly anchor themselves within the social landscape and establish a common ground on which to claim rights, responsibilities and relationships. It is this common ground - the cultural geography with all its attendant meanings and significations - which people in Amaya choose to emphasize above and beyond the designation of land as an economic base. Yet increasingly, as the recalled incident suggests, Mayawo stories are called upon to compete with a number of other discursive forms. Removed from their immediate referential topos and launched into this orbit of competition and abstraction, they circulate as fluid signs often subject to revision, ridicule and rejection.

\section{Conclusion}

In this paper, I examine the relationship between stories, people and the landscape. At one level, Mayawo narratives can be regarded as epistemological maps insofar as they constitute a theory of knowledge about the landscape as an ordered plane of named and pre-established places. In this sense then, the cultural geography represents the state of this knowledge and the field in which the production and reproduction of this theory takes place. This is done through the movements and displacements individuals effect when they act upon place and transform it into space. Mayawo narratives are thus also itineraries of practice in the same way that the landscape, when acted upon, becomes a text for conduct. Both delineate fields of operations and function to spatialize people's actions. Thus the cultural geography, and the narratives that make it, are simultaneously both map and itinerary, and in this sense they coincide with Ricoeur's distinction between the "reproductive" and "productive" imagination (1986). When both the cultural geography and local stories are no longer accorded this status or 
acted upon accordingly, or when itinerary is privileged to the point where the map is made redundant, or when the map itself is subjected to analysis and casuistry, then alienation and ambiguity arise. There is no longer a play of changing relationships between places and spaces, between maps and itineraries: the poetics of place succumb to the politics of space.

\section{References}

Certeau, Michel de

1984 The practice of everyday life. Berkeley and Los Angeles: University of California Press.

Corbin, Henry

1969 Creative imagination in the Sufism of Ibn 'Arabi. Princeton: Princeton University Press.

Geertz, Clifford

1973 The interpretation of cultures: selected essays. New York: Basic Books.

Pannell, Sandra

1989 Carving the palm: the role of metaphor in Mayawo marriage rituals. Mankind 19(3):160-170.

1990 Now we follow "Our Father": Christianity, colonialism and cultural transformation on the island of Damer, Maluku Tenggara. Cakalele $1(1 / 2): 27-47$.

1991 Narrative boundaries, national horizons: the politics of identity in Amaya, Maluku Tenggara, Indonesia. PhD thesis, The University of Adelaide.

1992 Journeys to other worlds: narratives of headhunting, appropriation and the Other in the "Eastern Archipelago". Oceania 62(3):162-179.

Ricoeur, Paul

1986 Lectures on ideology and Utopia. New York: Columbia University Press.

Sahlins, Marshall

1981 Historical metaphors and mythical realities: structure in the early history of the Sandwich Islands kingdom. Ann Arbor: University of Michigan Press.

Schneider, David

1984 A critique of the study of kinship. Ann Arbor: University of Michigan Press. 


\section{Notes}

1 A draft of this paper was presented at the Australian Anthropological Society Conference, 30 September-2 October 1992, in the session entitled "The Poetic Power of Place" convened by Professor James Fox. I would like to acknowledge the contribution of Daniel Vachon to the writing of this paper and his insightful comments regarding the constitutive significance of place. Barbara Grimes also offered her support for this reconsideration of the social importance of place.

2 Unlike Geertz's (1973) notion of cultural patterns as models of and models for "reality", with its attendant implications of circularity and stasis, Ricoeur's (1986) conceptualization of the social and cultural imagination as both reproductive and productive allows for, indeed is predicated upon, creativity and change.

3 In my previous writings on Damer, I have variously spoken of Mayawo narratives as "myth" (Pannell 1989, 1990) and "history" (Pannell 1991, 1992). The latter designation constitutes the preferred term in more recent accounts. This preference was informed by Mayawo use of the Indonesian term sejarah as a gloss for the indigenous term for local narratives - hynero. The term sejarah is commonly and widely interpreted in English as meaning, or as referring to, "history". While the appellation "history" might be an appropriate gloss for sejarah, in the light of my current reconsideration of Mayawo social forms and cultural logic, it now seems an unsuitable term to describe and denote the narratives I refer to in this paper. The construct topogeny, or even the neologism "topostory", appears more suited to delineating the content and concepts of the narratives. I should add that local usage of the term sejarah is not inconsistent with this view and is more probably a reference to the perceived veracity and empirical nature of local narratives than it is to the form that they take.

4 Readers familiar with my previous work on Mayawo social organization and social relatedness will note that the present discussion represents a considerable conceptual re-orientation to the original ethnographic data. Somewhat reminiscent of David Schneider (1984), recent questioning and, indeed, rejection of the traditional paradigm of kinship and social organization studies (which pervades the anthropological literature pertaining to eastern Indonesia) has resulted in a radically different understanding of the material. Accordingly, the present discussion represents but a brief allusion to a current and more considered re-analysis of place and its logical significance in the construction of "kinship" and social organization in Amaya. 


\section{Chapter 10. Seating the Place: Tropes of body, movement and space for the people of Lelet Plateau, New Ireland (Papua New Guinea) ${ }^{1}$}

\section{Richard Eves}

In what ways do people attach meaning to and organize space and place? (Tuan 1977:5).

In this paper I explore the relationship between people and place. My aim is to show how space is transformed into lived space or place. I explore the way that people conceive of themselves through the space that they imaginatively create around them. In particular, I show how this relationship is constituted through the body and through tropes of the body.

My discussion is based on ethnographic research among the Austronesian-speaking people of the Lelet Plateau in the New Ireland province of Papua New Guinea. The Lelet are the only remaining residents of the mountainous backbone of New Ireland, having resisted colonial pressure to relocate to the coastal fringe, as other inland populations have done. The population of about 500 people live in widely dispersed hamlets centred around four main villages which form the nucleus of social and political life. Like others in the Mandak language area, the Lelet are divided socially into two exogamous matrilineal moieties - Lamalom or Laragam. These moieties are further divided into matriclans and matrilineages. These people are swidden agriculturalists whose main crops are taro and sweet potato, with taro being - culturally and symbolically - the most valued.

Images of the body pervade Lelet conceptualizations of the way the world is constructed and inhabited. The use of corporeal tropes is an important part of the process by which these people develop attachment to their place (lemenemen). ${ }^{2}$ They construct a cosmology of space and place around the contrasting images of bodily comportment, especially those of an immobile body and a mobile body. I am not posing an immutable binarism here but pointing to the importance of the tropic constructions of the body and the flow of figurative possibilities that are imaginatively fashioned in this world view. ${ }^{3}$

These processes, using the body and tropes drawn from it, are examples of what Jackson (1989:138) has referred to as "thinking through the body". The tropic use of the body in constituting space and place is only one part of a wider 
process of the body's interaction with, and constitution of, the world. The body in its movement through space is integral to the process by which the world is known, valued and inhabited. In short, body movement for these people is integral to the transformation of space into lived place. An aim of this paper is to illustrate the play of tropes, or that process of "thinking through the body", as the Lelet negotiate the tension between the culturally constructed requirement of seating - or remaining in place, with its connotations of social harmony and the requirement to engage in movement, as a precursor of social interaction.

In the first part of this paper, I discuss some recent anthropological explorations of space and place. I then develop an analysis based on the work of Merleau-Ponty (1962), whose theory of lived spatiality locates the body in a centrally important position in the constitution of space as place. In the second part, I examine the symbolic construction of socially adopted space - in particular the manner in which powerful spirit beings define place for people. A primary association of people and their attachment and location in place is through these tutelary spirits, larada (masalai), who demarcate the landscape along matriclan lines (see also Jessep 1980). I use the example of the relationship of people with their larada to illustrate the contradiction between the desirability of being in place and the social imperative of movement within and away from place. In the third part, I discuss the notion of seating and describe contexts in which this body trope has significant meanings. Finally I examine the notion of mobility and its subversion of the trope of the place as (harmoniously) seated when people engage with others in constituting their social world.

\section{Beyond Cartesian Dichotomies: Conceptualizing Space and Body}

A number of commentators have drawn attention to the constitution of place and the importance of this for anthropological understanding (see also Feld 1982; Munn 1986; Pandolfo 1989; Pandya 1990; Stoller 1980 and Weiner 1992). Appadurai (1988:16), for example, has written that the "problems of place and voice are vital to anthropological practice and so is the relationship between them". Rodman argues that the question of voice has received considerable attention but that of place has not. She argues that the concept of place requires a rethinking and that "It is time to recognize that places, like voices, are local and multiple" (1992:643). Rodman suggests that, at best, place has been "seen purely as locale and the 'problem' is defined as if place were entirely an anthropological creation" (p.644). Following Entrikin (1991), Rodman says that the analysis of place requires examination of what she terms the "betweenness of place' in anthropological contexts, as both subject and object" (p.644).

In a similar vein, Basso (1988:101) has drawn attention to Western Apache representation of their landscape in ways that "are compatible with shared understandings of how, in the fullest sense, they know themselves to occupy 
it" $^{\prime \prime}$. Following Heidegger (1962), Basso suggests that, just as people dwell in their landscape, that landscape is said to dwell in them. This is because the conceptions the Apache use to fashion their inhabited landscape are the same as those used to constitute Apache persons (Basso 1988:122). In the reciprocal process of inhabiting the landscape and being inhabited by it, the Western Apache and landscape become "virtually one" (p.122).

Thus Basso, like Rodman, sees place not simply as an object external to people but as constitutive of their being. This view is succinctly explained by Dreyfus: "The relation between me and what I inhabit cannot be understood on the model of the relation between subject and object" (1991:45). ${ }^{4}$ While the arguments of Rodman and Basso are admirable, neither explores the full extent to which the way that people inhabit their world is predicated on a notion of the body and its movement - either the body itself or tropes drawn from the body and its comportments. I suggest that Merleau-Ponty (1962) offers a useful perspective of the "problem" of place in his critique of Cartesianism, where he places the body in a pivotal role as mediator between people and world (see also Jackson 1989:122; I.M. Young 1990a, 1990b). Previously in the philosophical tradition and in Euclidean geometry, space has been conceptualized in a limited sense as uniform, physical or geometrical, the container in which objects of experience are located (Langer 1989:80; see also Dreyfus 1991:139). In the measured space of Cartesianism, positions are external to one another and interchangeable (I.M. Young 1990a:151; see also Madison 1990).

In his critique of traditional conceptions of space, Merleau-Ponty (1962) argues that there is a distinction between lived, or phenomenal, space and the Cartesian, or objective, space of geometry and science. Similar Cartesian conceptions are to be found in theories of the body, where the division between subject and object reduces the body to another part of the quantifiable and measurable world of physical science (Jackson 1989:119). Since the seventeenth century the body has

been primarily identified with its scientific description, i.e., regarded as a material object whose anatomical and functional properties can be characterized according to general scientific law (Leder 1990:5).

Accordingly, the body is seen as essentially no different from any other physical object.

In opposition to this view, Merleau-Ponty sees the body not simply as an object in the world but as the means through which the world comes into being. In his concepts of the lived body and lived spatiality, Merleau-Ponty transcends the dichotomizations of previous conceptualizations of space, by placing the body to the forefront. He rejects the traditional Cartesian conceptions of space and body, focusing instead on the "dynamic pre-objective, pre-logical interaction 
of body-subject and world" (Langer 1989:88). Especially important is the figure-background or point-horizon structure against which any body in space is located and which changes according to movements of that body. Thus Merleau-Ponty writes:

As far as spatiality is concerned ... one's own body is the third term, always tacitly understood, in the figure-background structure, and every figure stands out against the double horizon of external and bodily space. One must therefore reject as an abstraction any analysis of bodily space which takes account only of figures and points, since these can neither be conceived nor be without horizons (1962:101).

According to Merleau-Ponty's phenomenology of lived space, spatiality cannot be conceived without horizons; neither can it be conceived without the movement of the body against those horizons. The figure-background structure which the body inhabits

becomes the background against which movement can stand out; consequently, movement presupposes inherence in the world which is established and maintained by the habitual body (Langer 1989:87).

Merleau-Ponty argues that by considering the body in movement, a better understanding can be gained as to how it inhabits space:

because movement is not limited to submitting passively to space and time, it actively assumes them, it takes them up in their basic significance which is obscured in the commonplaceness of established situations (1962:102, and see also Straus 1966:45).

For him, movement as a basis of intentionality or consciousness (or his technical term, "motility") becomes not solely "a matter of 'I think that' but of 'I can' " (1962:137).

But, while Merleau-Ponty's theory is valuable in understanding how the body inhabits space, particularly how bodily movement is constitutive of space, any full conceptualization of space must be coupled with an analysis of, and be grounded in, a concept of space as social space. The movement of the body, which Merleau-Ponty sees as important to the constitution of space, does not exist outside of people's symbolic construction of socially inhabited space and also of the body. Thus, for the people of the Lelet Plateau, the movement of the body is not absolutely free or unhindered, as Merleau-Ponty presupposes, but is regulated and restricted by the cultural conceptions of social space. To gain an accurate picture of the way space is given meaning and transformed into place requires an understanding of the means through which social space is constituted by symbolic processes. 


\section{Larada: Delineating and Demarcating Space}

Larada (masalai) are territorial beings located on a clan's land but are by no means permanently "seated" there, having the capacity to leave one abode for another, or one place for another. ${ }^{5}$ This is one of the primary means through which space becomes demarcated and thus recognized as place. The travels of larada and the sites at which they settle are also part of the process by which the land is named; the Lelet Plateau is dotted by numerous abodes named in this way. Knowledge of the origins of these names, and of the means by which the larada came to be there, is significant in the justification of claims on land. Larada, I was told, "get up and sit down in other places". This ability to move, and thus to migrate, means that a clan's land can be scattered over a large geographical area. These dispersed clan lands are an indication of the past migrations of the larada and, reciprocally, of the clans that inhabit that land. Like the Dreaming stories of the Australian Aborigines, a mythic topography of place is crafted as these powerful beings traverse the landscape, structuring undomesticated space into place (see Myers 1986:48).

The movement of larada from their abodes — lubungtada (ples masalai) can be temporary or permanent. Their temporary movement, referred to as larada lalan, is common at night. Larada that do not roam around are referred to as larada kitkis, meaning "the larada are firmly seated". The temporary travel of larada is not random or arbitrary but is along well-known paths between abodes. They are said to move from the dominant or central abode - the laxatlitada ("eye" of the larada) — to other sites dispersed around a clan's lands. These other lubungtada may be situated nearby or several kilometres away, depending on how many separate parcels of land belong to a clan. For example, Simut, a snake larada of the clan Katanuat, resides near a large tree located close to the hamlet Lenuat but sometimes changes places with another snake larada living at a tree-lined ridge a few hundred metres away. Simut also travels to other larada abodes, such as Latbeve, and formerly visited a water-hole abode called Merakeke, now dry and no longer an abode.

Narrative accounts of the permanent movement of larada explain the way clans come to migrate, colonize and inhabit new lands. In these stories, larada have travelled to other places and, in that movement, have claimed new areas of land for their clan. At these times, the larada in their embodied forms often move along valleys of unowned land, making paths which open up vacant space for colonization. Land that has already been delineated by other larada, and thus claimed, cannot be reclaimed. If a migrating larada attempts to traverse land already claimed by another larada, the latter will be angered.

The following origin narrative illustrates this claiming of land through larada movement. The clan of Luben had its beginning in the sea at Kinaba on the west coast of New Ireland, in an oyster (laxalas), the shell of which is used by women 
to peel taro. In this originary time, some men were on a reef, fishing with a net (uben). Nearby there was a larada abode - a lubungtada - a hole in the ocean called Kanemara. This larada was avoided by people in canoes, for if a person's shadow were cast into the hole, that person would die. The oyster larada would not leave its abode during the day, but only at night. One night when the oyster larada was moving about on the reef, it was caught by the fishermen in their uben. When they had caught enough fish, the fishermen went ashore to divide their haul and then to cook some of it. They decided to cook and eat the captured oyster larada. It was placed on the fire to cook and thus to open, but to no avail. They tried to open it with a knife, but this also failed. One man then tried to smash the oyster open with a rock, but this did not succeed either, the oyster remaining intact. Finally admitting defeat, the men threw the oyster away. During the night when the fishermen were all asleep the larada communicated through a dream with the man who had tried to smash the oyster open. The oyster told the man that he would from now on bear the name of uben and the larada would be his guardian.

The clan legend of Luben continues: the discarded oyster, together with the fishermen's net which also became a larada, journeyed from this site to a water-hole at a place named Sarum. This water-hole then became a larada of the clan Luben. The oyster larada, however, did not remain "seated" here for very long because a person in an avoidance relationship with it visited the pool. This lack of respect caused the oyster larada to flee once again. From this coastal area, it moved into the mountains of the Lelet, journeying via the hamlet Tumalom at Kaluan, where it found that all of the land was already occupied by other larada, and thus other clans. It then moved to the other side of the plateau where it found an unoccupied area of land. Here the oyster larada and its companion went to a place where the oyster made a hole for the net to reside in. This larada abode was named Lubentada after the primary larada residing there - the Luben. Afterwards, the oyster larada journeyed to another place and made a hole there, naming this place after itself - Lurugalas-silok. It then moved and made a further hole, also naming it after itself - Lurugalas-lik. Finally, when the oyster larada made its abode, the net larada Luben moved to demarcate the boundaries of the Luben clan land, in a way similar to that used in enclosing and trapping fish. As Luben journeyed along valleys and over mountains, mapping the space of its land, it occasionally came to the boundaries of other clan lands, so that it was forced to change its route. For example, in the south its path was restricted by the land of the clan Kantaon, in the north-east by the land of the Bungaring, and in the west by the land of the Solong.

The Luben clan leader who told me this legend of the origins of his clan and its larada admitted that he had never seen the oyster larada, but he authenticated his story by pointing out that coastal vegetation grows at the places where the larada now resides. Further authenticity is furnished by the existence of an 
omen that indicates impending death of a member of the Luben clan. Should a Luben member be about to die, the oyster larada makes an exploding sound.

The narratives of the movements of larada are the means through which the landscape is imaginatively fashioned, giving people identification and attachment to place. The wandering movements are part of the process by which the space is named and transformed into meaningful lived or socialized space or place when the larada - and following them, people - finally take up residence. These movements become the inscription or signature which verifies and authenticates ownership of that landscape. The narratives serve not only as the means by which emotional and aesthetic roots are attached to place, but they are also important in giving people genealogical connection to that land, and thus rights of ownership and control. Once the larada have ceased their travels, their human clan members can legitimately occupy the newly colonized land becoming "seated" in place. This "seating" for larada, as well as for their clan members, while giving the illusion of permanence, is nonetheless subject to contingencies that require journeying to be resumed.

\section{Larada Spirits: The Attachment of People to Their Place}

As Tuan notes "Space is transformed into place as it acquires definition and meaning" (1977:136). Larada are pre-eminent in giving this definition and meaning to place. ${ }^{6}$ These larada are powerful tutelary spirit beings rooting or locating particular clans in bounded locales and giving them an abiding attachment to that land and place. These spirit beings, which like humans have the ability to move from their place, enact the dialectical tension between immobility (being seated in place) and mobility (movement away from place).

Larada are powerful, knowledgeable and, in some circumstances, vengeful clan-based spirits who can take on multiple bodily configurations. They have a transformative potential and consciousness that allows them to occupy different bodies, spaces and ontological states for any reason. Sometimes these forms are visible, such as the phenomenal form of a snake, or invisible, and experienced only through revelatory dreams. They can manifest themselves in many forms such as those of possum, dog, pig, eel, oyster, shark or octopus. They can also embody or inhabit a large number of other material forms such as trees, stones, water-holes and caves. Often they have unusual or abnormal appearances and properties, a uniqueness that sets them apart from normal living things and objects. They can refigure themselves as being monstrous in appearance, taking on the form of an unusual shaped stone, a deformed plant or a two-headed possum, for example.

Their powers of transformation and refiguring allow them to transcend the everyday experiential boundaries to which humans are subject, and this makes them a source of power for humans. The spaces they occupy are important in 
generating knowledge of a magical or aesthetic kind. In the past, these sites were significant in the creation of malangan figures that were displayed at mortuary feasts. More recently, the powerfully charged spaces that larada occupy are the places where men are initiated into the imported shamanic cult of Buai (literally betel-nut or areca nut), which gives them access to the transformative powers that larada embody, facilitating shamanic divination and sorcery flights. Normally the power of transformation over corporeal form is used by larada to trick and invoke fear in people, especially those who transgress rules of avoidance and respect by trespassing upon the larada's abode. This transformative power is termed $i$ axalat, glossed as the power to metamorphose, to trick, challenge, tease and frighten and/or the power to cause harm.

Among the people of the Lelet, clan members do not fear, nor can they be harmed by, the larada of their own clan and the relationship is conceptualized as one of kin. A person can go close to their respective larada and, if it takes the form of a tree or a clump of bamboo, can even cut it down without fear of retribution. ${ }^{7}$ In other circumstances larada are capricious and harmful beings. The dealings between a person who has married a member of a clan and that member's larada is governed by protocols of avoidance and respect. A man or woman must respect the larada of their spouse by avoiding its abodes, which are forbidden places (lenkotkala). The relationship between a person and their spouse's larada is similar to the affinal relations between a mother's brother and sister's son who each call the other's wife nasong and are called nasong by the respective wife. Irrespective of sex, the larada and the spouse occupy the nasong relationship; the spouse must maintain respectful avoidance (lok ngao) of the larada, and vice versa. The relationship of a person to their spouse's larada is one of shame (lok mamang), just like relations between two nasong.

Not only is the relationship between a person and their spouse's larada one of respect, it is also governed by fear, especially when the person lives or visits his or her respective spouse's clan land. This fear leads people to circumscribe their behaviour, and may take many forms, such as not going to certain places at night lest one meet a larada, not washing in a larada water-hole (latbungtada) or abstaining from certain foods. For example, I was told that some people do not eat chickens because, in scavenging for food, they may have eaten a larada in the form of a snake. A person resident on the clan land of his or her spouse does not dispose of rubbish close to places where larada reside lest they consume it, resulting in illness for the careless person. People who live on the land of the larada of their husband or wife try not to disturb the larada in any way. They avoid going to areas where the larada are thought to move, lest they step over its path and subsequently become ill. Choice of a place of residence is often governed by fears for the safety of a spouse. One man told me he did not live near his traditional men's house because it was too close to the abode of a larada 
of his clan and he feared for the safety of his wife who had nearly died previously when she cut a snake larada from a nearby abode while gardening.

People who do not respect and avoid the larada in a nasong relationship are likely to have their body colonized by the larada, causing illness and even death. It is said that the larada, seeing that a person does not exhibit shame, decides to marry that person, a euphemistic way of saying that the larada has sexual intercourse and colonizes the internal spaces of the body. One such account illustrates the transformative power of larada vividly. This involves the larada of Tunau clan, Lubungumo, a black python with two heads (one head coloured with red ochre and the other coloured white with lime powder) who is reputed to have killed several men and women who disregarded affinal etiquette by venturing too close. In one case a woman had sexual intercourse with a man at the abode of Lubungumo, who seeing this transgression, invaded the woman's body as retribution. During the daylight hours the woman's stomach became distended by the snake inside. The larada migrated at night, so that her swollen stomach slackened. Leaving via her anus, the larada snake, "screeching like a pack of rats", would return via the same orifice to recolonize her body at dawn. This continued until her death, whereupon Lubungumo left her corpse and moved back to its usual abode.

This story shows that the effects of not observing the appropriate etiquette of avoidance and shame are catastrophic. Moving into close proximity to a forbidden place inhabited by the larada causes the larada to desire the transgressor - a desire that only ceases at the latter's death.

\section{Seating the Place}

In the earlier discussion of larada, I showed that the body comportment of seating is a trope for the ownership and habitation of place. In the process of larada becoming seated in unclaimed tracts of land, space is possessed, named and converted into an inhabited place for the larada's human kin. In this context seating is an important comportment of the body and is used as a trope for marking the stabilization of identity and its union with space.

However, the evocative ways in which seating is employed go far beyond those I have described in relation to larada. Seating is one of the most widely used body tropes employed on the Lelet, and is commonly used in reference to place and to the social states there. In its most potent usage, it is applied to the community in prosperous and harmonious times - limila.

Limila means much more than the mere abundance of food; it also evokes meanings of social well-being and harmony, a state that is now sometimes glossed by the word "peace". In discussion, people usually say that limila means "the place is sitting down well and there is no disruption" or "the place is seated well and there is an absence of famine". The state of limila is said to exist after war 
or social disruption, times when the village or place is described as "sitting down" well. Similarly, conflicts between people over land, or over various social transgressions such as adultery, are seen to reflect an absence of being seated properly. In a recent sorcery accusation the place was referred to as "sitting down broken" (lixis epeseves) evoking connotations of a community dispersed. People also use similar terms to speak of the loss of traditional ways (loklok at lemenemen, or kastam) and the failure of the younger generation to accept the authority of village leaders. In such contexts, seating becomes part of a moral discourse nostalgically bemoaning the lost power of the leaders and is part of a wider critique of the people's encompassment by colonial and post-colonial social forms in which the past is reified.

The tropic use of the body comportment of seating in relation to food beliefs and famine clearly illustrates the figurative relationship between the body (its states and dispositions) and place. In the cosmology of the Lelet people, the abundance of food comes to symbolize heaviness and immobility whereby the body and place are seated well. The absence of food symbolizes a state of lightness in which both body and place assume a state of restlessness and mobility, and thus neither body nor place are seated well. Famine involves continual movement from settled place to the undomesticated spaces of the forest in search of bush foods that lack the filling and satiating properties of domesticated crops such as taro. In such times, food is not shared among others but is withheld for retention within, and satiation of, the individual's own body, leading to social tensions. Thus, absence of food, and consequently lightness, figuratively represent a state of being characterized by mobility or restlessness with accompanying social tension and disruption. ${ }^{8}$ Heaviness, on the other hand, symbolizes fertility and the abundance of food, accompanied by the values of generosity and general social harmony.

These images of immobility and mobility are exemplified most powerfully in relation to the culturally important root crop taro. Taro is an ambiguous food; on the one hand, it is seen as the archetypal "heavy" food that sits in the stomach giving the body its strength and capacity for productive work (see also Mitchell 1976:25 and Oliver 1971:57). On the other hand, it has the capacity to move away from place, especially through magical enticement or sorcery, thus causing famine. The taro plant is called pas or lavas, and very much signifies movement, these nouns deriving from the two verbs $i$ tpas and $i$ vas meaning to walk. A particular type of magical song is used by people to entice the spirit of the taro's regenerative stalk from other people's gardens to their own. Until recently, the movement of taro from place to place was prevented by the performance of elaborate magical rites, called lemeravas, which were aimed at "seating the taro" (ba xis loxongkun) and thus "seating the place" (ba xis lemenemen). These rituals used powerful magical stones and incantations to make the taro take on the 
heavy and immobile state embodied in the stones, ensuring it was seated firmly in place.

For people to be rooted steadfastly in their place is a highly desirable state. However, it is one that is not entirely achievable since people must submit to the exigencies of life. In certain strategic and pragmatic contexts, mobility is also highly desirable. Seating is only one possibility of bodily comportment and people come to occupy other positions that subvert the trope of seating. Seating is evocative not only of motionlessness and stability; it also implies the potential or intention to move or travel. Thus being seated portrays a transitory position. Being seated, I suggest, is an attitude of the body assumed before or after other states such as sleep, running, walking or standing. A body, for example, is seldom permanently seated, except in the case of infirmity, but sits prior to some form of movement. Mobility subverts the cultural imperative for immobility in place, as these two body images dialectically play themselves out in cultural and social praxis.

Thus, like other tropes and symbols employed by the Lelet people, the conception of seating is not only polyvocal - its meaning varying according to context - it can also be ambiguous. The trope of seating, on the one hand, is associated with abundance and plenitude when taro is firmly seated and famine avoided. On the other hand, it can be associated with characteristics antithetical to this. An example is the immobility occasioned by severe illness and old age leading to death (see also Jackson 1989:148). There is a very poignant song composed by a man made immobile by leprosy. Because of his illness, the man could not host a mortuary feast for a sister and was subjected to the scornful gossip of two other Big Men. The song follows:

I am standing [atu] here, I am standing, I am standing here, I am standing here. It is only I who remain [nemen] here. I do not have anything for feasting because illness has affected me. Where shall I get good strength from? It does not matter that this illness follows me. You have belittled me, I shall belittle you. They buried the old woman close by. Have you seen the two birds who sit and stare outside here?

It is only I, an orphan, who remains here; my parents are dead and I have chased the two of them before. I am standing here, am standing, I am standing here. It is only I who remain here. I do not have anything for feasting because illness has affected me. Where shall I get good taro and pigs from? It does not matter that this illness follows me. You have belittled me, I shall belittle you. They buried the old woman close by. Have you seen the two birds who sit and stare outside here?

Throughout this song the man reminds the two Big Men that it is only because of his illness that he cannot host the feast for his dead sister. "Where shall I get 
the strength from?" he poignantly asks. He then likens the two men to two birds (luxalanga) who only sit in their hollow-tree nest and stare blankly outside. Commonly, this term is applied to old people who remain in a hunched-over sitting position and are unable to move, occupying what Munn has referred to as "the pole of motionlessness expressed also in sleep, illness, and death" (1986:76). ${ }^{9}$ Although the man refers to the two men in this way, in reality it is he who is rendered immobile, able only to sit and stare out from his house and unable to summon the strength, or to call on support from others, to silence his challengers through feasting. The essential isolation of his plight is emphasized by his constant reference to being an orphan, but despite this the composer allegorically reminds his two taunters that when his parents died he achieved great fame by hosting their mortuary feasts. This is achieved through the allusion to having chased the two Big Men, a euphemistic way of saying that he has humbled them by his feasting efforts. Perhaps the most important point to draw from this song is the constant reference to standing, something I will return to later.

\section{The Mobile Body and Place}

As Tuan has noted, "Place is a pause in movement ... The pause makes it possible for a locality to become a center of felt value" (1977:138). Seating, I argue, can thus be seen as only one state of the many possible comportments and dispositions of the body. The temporary pause in movement embodied in the act of seating allows people to develop an attachment towards that place. Paradoxically, movement is the primary means through which people come to experience, share and know their place, as Merleau-Ponty argues. Movement is the way people inhabit their place, the means by which they mark out the boundaries of the space they own and inhabit. As people move and get to know the space around them better they come to endow it with value (Tuan 1977:6). However, felt and embodied attachment to place does not exist outside of temporality. Over time, as people traverse their place, their experiences of life give further meaning to that place. Not only is the moving body important to the valuing and knowing process but that body occupies a key position in people's understanding of space.

Through the body and its movement, by mere presence of the human being, the world has a schema imposed on it (Tuan 1977:36). As the body moves, its relation to the cardinal directions change (see Codrington 1885:164-165 and Straus 1966:33). Thus, whenever people on the Lelet move from village to village, or from hamlet to hamlet, they constantly reference themselves and their body to space. When people travel, they refer to the direction they are moving toward and/or whether they are moving upward or downward. Objects, too, are positioned according to their orientation to the body. In effect, the body and the landscape it inhabits come to be as one (see Grange 1985:76). 
On the Lelet, walking is the pre-eminent mode of travelling throughout place and is the means by which people come to know and experience the world around them and imbue it with that meaning that socially constitutes it as place. Walking is also a basic precursor to social interaction, one of the means by which social relationships are established and maintained. ${ }^{10}$ People walk from place to place in the process of visiting kin and friends. To remain in one's hamlet and not travel beyond its boundaries evokes the image of the anti-social person, the lantupe, who sits alone in the house not sharing food and eating alone. ${ }^{11}$ There is significance in the fact that the movement between places is negotiated via paths (langas), which allow connection with others in a wider community of sociality and exchange. Paths have important connotations of the way wealth is acquired - by both labour and magical means (see also Bonnemaison 1985:50). Paths are also the sites for the performance of protective magical practices geared to warding off famine and illnesses. In these rites, the magician walks and steps on stones at the hamlet's boundaries, sending any evil influences back along the path from whence they came. ${ }^{12}$

Walking is only one means by which people experience the world around them and imprint their presence on it. Body movement in general can also be said to play this role and is a pre-eminent means through which people define themselves and their position in the world. For the people of the Lelet, one's social self is expanded by the movement of the body, primarily through work in the garden. Through work, manifest strength is strategically realized and transformed into items of exchange at feasts. This process of transforming controlled movement into fame reaches its zenith during the climactic mortuary feast, the lokpanga — where the hosts expand their selves through the distribution of pork and taro. The fact that the giving of exchange items must be reciprocated at later feasts means that the feaster, to quote from Nancy Munn, "can produce for [the self] the possibility of gaining something beyond that time" (1986:11).

The song of the leper, above, is instructive in contrasting the immobility of the sitting birds with the strategic mobility of standing. In the song, standing is a metaphor for hosting a feast, an act which cannot be carried out by the isolated, but only by those who can draw on and muster the support of others. To stand, in this context, is an act of assertion. By repeatedly asserting that he is standing, the immobile leper is showing that he is not yet totally incapacitated. I am not sure whether this assertion is accurate, but as a rhetorical device it is evocative of the man still having power. By asserting that he is standing and his two taunters are sitting, the leper is poetically inverting the actual spatial relationships and hierarchies by positioning his body above their bodies and thus figuratively dominating them. Here he is alluding to the power politics of feasting. At mortuary feasts it is a common practice for the feast host to climb on to a mound of stacked pigs prior to the final pork distribution. The stacking 
of several pigs usually occurs over an enclosure of uncooked taro which will be distributed with the pork after the Big Man has completed his song ( $i$ vavang). In the past, other structures called gilam were constructed. This consisted of uprooting a tree and then inverting it with the top in the ground and the roots above. The structure was reinforced with buttresses and painted red. The receptacle formed on the inside of the roots had taro (or on the coast coconuts) placed there. Pigs are then placed on top of this. At a mortuary feast I attended in the Barok language area in 1991 I saw one of these structures (called kaba among the Barok) erected. About thirty pigs were placed on the top and when the Big Man gave a speech he was about 5 metres above the ground (see also Wagner 1986).

From his position above the gathered crowd of guests, the host sings a song celebrating the efforts of himself and his clan to organize the feast. Often these songs recount the efforts of orphaned children, who, despite adversity, finally complete the mortuary feasting cycle for their parents. At these climactic spectacles the host sometimes brandishes a spear or cordyline plant in an aggressive show of power as he dances on the pigs. This act of dancing on top of the slaughtered pigs is similar to the assertive and aggressive acts of past warriors who danced and sang on the bodies of their slain enemies as they brandished their weapons. In the present post-pacification times, fighting with weapons is to be replaced by "fighting with food" (see M.W. Young 1971).

Bodily movement, such as standing or using one's body in gardening, is valued highly. Failure to manifest strength through gardening work is viewed with extreme disdain, because it is through such directed bodily movement that people create their identity and personhood. The younger generation (mainly young men) are decried for their alleged "passivity" or "laziness" because they do not harness their bodily movement to appropriate ends. Although, paradoxically, they are seen to be in constant movement, these forms of movement are not directed, are unproductive, and hence unvalued. In their travels between hamlets for socializing, young men are seen to dissipate their strength pointlessly, movement which would be better spent, according to their elders, in productive gardening work. ${ }^{13}$ Such uncontrolled movement and travel is referred to as $i$ sasa, a term also used to designate the uncontrolled movement of children as they wander and play, and people who move from hamlet to hamlet around mealtimes in search of food are called lansasa (see also Modjeska 1991:253). This term is also applied to people who move from residence to residence, never becoming settled permanently in one place. This latter form of restless or unrestrained mobility is disparaged. It is an exceedingly cutting insult to refer to a person who moves house frequently in these terms, or as a flying fox, an animal noted for its constant and restless movement. 
Among the people of the Lelet, men's movement is much less restricted than that of women, whose movement in space is hedged with more kinship rules. The spatial positioning of the body reflects the gender hierarchy. Stringent avoidance relations among close kin and affines are practised on the Lelet. Some of the strongest restrictions apply to opposite sex siblings, brother and sister. Thus should a pair of siblings meet on a path, the two should avoid coming into close proximity with each other, the onus being on the woman to move out of the man's path. In practice, this often means a woman turns and moves into nearby bushes, or she may simply look in the opposite direction. If a certain man has carried a flooring beam for a house, women who are in an avoidance relationship with him will not enter that house. If a woman were to step onto a beam that a brother had carried on his shoulder, symbolically she would be surmounting his shoulder. In doing this, the woman has positioned herself spatially above the man, who occupies a place where he can see the woman's genitals. In such contexts, there is a strong equation between seeing and desire. In this spatial positioning, the brother will not be able to control his desire for his sister and the incest prohibition will be breached. Furthermore, this same construction of seeing = desire means that women cannot move spatially upwards by climbing trees because this involves the positioning of their bodies above men.

The gendering of space, body and movement is also apparent in hunting. For example, men are thought to have the strength and speed lacked by women to pursue wild pigs, and so hunting, and the spaces in which it is carried out, are very much a male domain. There is a secret language that is known only by men and used by them to communicate with the various bush spirit beings, lagas (tambaran), that inhabit the forested hunting terrain and control access to game there.

Men are also much more able to move without restriction when they socialize, whereas women must move in pairs to escape the alleged threat of assault. Because of such restrictions and perceptions, women tend to remain located in the domesticated spaces of the hamlet and garden. Women's names, too, reflect the immobile state women embody. The verb to seat, kis, is often used to derive women's names. An example is Kiskot, which means to make one's home in a place which is not a traditional hamlet site. ${ }^{14}$ Men's names tend to be derived from actions or from objects that have connotations of mobility, such as pigs, fish or wealth.

Just as the trope of being seated has ambiguities and is polyvocal, movement too entails ambiguity, contradiction and polyvocality. While movement and travel often involve the expansion of the self as it engages with the world and the people inhabiting that world, it is not unproblematic. According to van den Abbeele's discussion of the metaphor of travel, while movement "posits the risk 
and anxiety of death, it also signals the way to health, wealth, and wisdom" (1992:xvi). Not only does movement from, and within, place pose the danger of loss, but it also poses the possibility of gain. There is potential risk as people move from the places they know and inhabit to other places for exchange, hunting or other pursuits. Moving into the undomesticated spaces of the forest, to hunt or to collect building materials, means to risk becoming lost. This happened to a boy from the village of Lavatkana, who returned to the forest to find something he had lost while collecting building materials, and who himself became lost, never to return.

Another example of the risks involved in movement and travel is the spirit flights practised by magicians schooled in the shamanic arts of Buai. These powers are acquired and transmitted through revelatory dreams which occur at the abodes of larada or lagas. The magical powers obtained from these spirit beings allow the shaman's spirit to travel from his body and enter the corporeal form of another being (eagle, wallaby, pig or shark) to commit acts of sorcery or divination. Although these spirit travels are powerful acts indeed, there is the risk that the spirit of the shaman will not return to his corporeal body, thus occasioning his death. Spirit travels, whether magical or not, can be gainful in producing significant innovations and new forms of knowledge. The acquisition of knowledge and power through dreams and magical flight involves the transgression of the normal spatial boundaries, especially the transcendent vertical spaces which are normally restricted to the movements of birds and flying foxes.

This is the case with the strategic movement used in feasting, which, although it involves the expansion of the self as it engages with the people inhabiting the social world, is not without danger. If a person journeys to a feast, there is the risk of being sorcerized. This can also be the case for feast hosts, who, while

gaining fame from their enterprise, are also left open to sorcery attack by others who are jealous or belittled by the spectacle.

\section{Conclusion}

A primary tenet of this paper is that bodily movement, and the tropes drawn from it, are important in the creation and constitution of place for the people of the Lelet Plateau. The body and its tropes are central to the symbolic processes by which space is realized and possessed as place. It is through these processes that people bestow new imaginative constructions upon space and make it richly meaningful, thus creating their place.

Thus, the Lelet people create their sense of self and personhood through the imaginatively created space which surrounds them. Their sense of who they are and their identity with their place - lemenemen - is creatively constituted through the larada spirit beings who, in their movements, map out the landscape 
as a place of habitation for people. Through the larada, these people have an abiding relationship with the land they inhabit.

A particularly important body trope employed in self construction by the people of the Lelet is that of seating, which has connotations of social harmony and abundance. Nonetheless, there is a recognition of the necessity that other bodily comportments and movements be undertaken in order that people can constitute themselves in their social world. Within this social world, powerful moral discourses censure movement that is not controlled, willed and strategic, and value controlled and strategic movement through which bodily movement can be transformed into fame. Theories of spatiality that posit space as something externally "out there", conceptualized as an object to be acted upon by human subjects, are inadequate because they fail to take into account the complex dialectical interaction between human and space. At the heart of this dualism is "man" as disembodied mind/subject. Some recent anthropological writings on space and place fail in their attempts to overcome the Cartesian dichotomization of space and the human because the body remains absent, in dualistic fashion, in their accounts.

Merleau-Ponty's writings are valuable because, in his critique of Cartesianism, he situates the body and its movement in central place in the theory of spatiality. His theory of lived spatiality is important in breaking down the conceptualization of space as merely an object and seeing it as both constituted by and constitutive of the human subject.

In my elaboration of the pivotal role that the body and its movement plays in the conversion of space into place, my inspiration has been derived from Merleau-Ponty. However, I consider that his theory needs to be supplemented and grounded in a theory of social space and social body. The body whose movement is constitutive of space for Merleau-Ponty is not prior to its symbolic and imaginative constructions and neither is space. There is a strong sense in which space is transformed into place not only through individual experience and perception but through socially derived experience and perception.

\section{References}

Abbeele, Georges van den

1992 Travel as metaphor: from Montaigne to Rousseau. Minneapolis: University of Minnesota Press.

Appudurai, A.

1988 Introduction. Place and voice in anthropological theory. Cultural Anthropology 3(1):16-20.

Basso, K.H. 
1988 "Speaking with names": language and landscape among the Western Apache. Cultural Anthropology 3(1):99-130.

Battaglia, D.

1991 Punishing the yams: leadership and gender ambivalence on Sabarl Island. In M. Godelier and M. Strathern (eds) Big men and great men: personifications of power in Melanesia, pp.83-96. Cambridge: Cambridge University Press.

Bonnemaison, J.

1985 The tree and the canoe: roots and mobility in Vanuatu societies. In M. Chapman (ed.) Mobility and identity in the Island Pacific. Special issue of Pacific Viewpoint 26(1):30-62.

Clay, Brenda

1986 Mandak realities: person and power in central New Ireland. New Brunswick, NJ: Rutgers University Press.

Codrington, Robert Henry

1885 The Melanesian languages. Oxford: Clarendon Press.

Dreyfus, Hubert L.

1991 Being-in-the-world: a commentary on Heidegger's Being and time, division 1. Cambridge, MA: MIT Press.

Entrikin, J. Nicholas

1991 The betweenness of place: towards a geography of modernity. Baltimore: Johns Hopkins University Press.

Feld, Steven

1982 Sound and sentiment: birds, weeping, poetics, and song in kaluli expression. Publications of the American Folklore Society, new series, vol. 5. Philadelphia: University of Pennsylvania Press.

Fernandez, J.W.

1991 Introduction: confluents of inquiry. In J.W. Fernandez (ed.) Beyond metaphor: the theory of tropes in anthropology, pp.1-13. Stanford: Stanford University Press.

Grange, J.

1985 Place, body and situation. In D. Seamon and R. Mugerauer (eds) Dwelling, place and environment: towards a phenomenology of person and world, pp.71-84. Dordrecht: Martinus Nijhoff.

Heidegger, Martin 
1962 Being and time (translated by J. Macquarrie and E. Robinson). Oxford: Basil Blackwell.

Jackson, Michael

1989 Paths toward a clearing: radical empiricism and ethnographic inquiry. Bloomington: Indiana University Press.

Jessep, O.

1980 Land demarcation in New Ireland. Melanesian Law Journal 8(1\&2):112133.

Langer, Monika M.

1989 Merleau-Ponty's phenomenology of perception: a guide and commentary. Basingstoke: Macmillan.

Lawrence, Peter

1964 Road belong cargo: a study of the cargo movement in the southern Madang district New Guinea. Manchester: Manchester University Press.

Leder, Drew

1990 The absent body. Chicago: University of Chicago Press.

Madison, G.B.

1990 The hermeneutics of postmodernity: figures and themes. Bloomington: Indiana University Press.

Merleau-Ponty, M.

1962 Phenomenology of perception (translated by C. Smith). London: Routledge and Kegan Paul.

Mitchell, Donald D.

1976 Land and agriculture in Nagovisi Papua New Guinea (Monograph of the Institute of Applied Social and Economic Research No. 3). Boroko: Institute of Applied Social and Economic Research.

Modjeska, N.

1991 Post-Ipomoean modernism: the Duna example. In M. Godelier and M. Strathern (eds) Big Men and Great Men: personification of power in Melanesia, pp.234-255. Cambridge: Cambridge University Press.

Munn, Nancy D.

1986 The fame of Gawa: a symbolic study of value transformation in a Massim (Papua New Guinea) society. Cambridge: Cambridge University Press.

Myers, Fred R. 
1986 Pintupi country, Pintupi self: sentiment, place, and politics among Western Desert Aborigines. Washington: Smithsonian Institution Press, and Canberra: Australian Institute of Aboriginal Studies.

Ohnuki-Tierney, E.

1991 Embedding and transforming polytrope: the monkey as self in Japanese culture. In J.W. Fernandez (ed.) Beyond metaphor: the theory of tropes in anthropology, pp.159-189. Stanford: Stanford University Press.

Oliver, D.L.

1971 Horticulture and husbandry in a Solomon Island society. In L.L. Langness and J.C. Weschler (eds) Melanesia: readings on a culture area (Chandler Publications in Anthropology and Sociology), pp.52-67. Scranton:

Chandler.

Pandolfo, S.

1989 Detours of life: space and bodies in a Moroccan village. American Ethnologist 16(1):3-23.

Pandya, V.

1990 Movement and space: Andamanese cartography. American Ethnologist 17(4):775-797.

Panoff, F.

1970 Food and faeces: a Melanesian rite. Man 5(2):237-252.

Powdermaker, Hortense

1933 Life in Lesu: the study of a Melanesian society in New Ireland. New York: W.W. Norton.

Rodman, M.C.

1992 Empowering place: multilocality and multivocality. American Anthropologist 94(3):639-656.

Stoller, $\mathrm{P}$.

1980 The negotiation of Songhay space: phenomenology in the heart of darkness. American Ethnologist 7(3):419-431.

Straus, Erwin W.M.

1966 Phenomenological psychology: the selected papers of Erwin W. Straus (translated by E. Eng). New York: Basic Books.

Tuan, Yi-Fu

1977 Space and place: the perspective of experience. Minneapolis: University of Minnesota Press. 
Turner, $\mathrm{T}$.

1991 "We are parrots", "Twins are birds": play of tropes as operational structure. In J.W. Fernandez (ed.) Beyond metaphor: the theory of tropes in anthropology, pp.121-158. Stanford: Stanford University Press.

Wagner, Roy

1986 Asiwinarong: ethos, image, and social power among the Usen Barok of New Ireland. Princeton, NJ: Princeton University Press.

Weiner, James F.

1992 The empty place: poetry, space, and being among the Foi of Papua New Guinea. Bloomington: Indiana University Press.

Young, Iris $\mathrm{M}$.

1990a Throwing like a girl: a phenomenology of feminine body comportment, motility, and spatiality. In I.M. Young, Throwing like a girl and other essays in feminist philosophy and social theory, pp.141-159. Bloomington: Indiana University Press.

1990b Pregnant embodiment: subjectivity and alienation. In I.M. Young, Throwing like a girl and other essays in feminist philosophy and social theory, pp.160-174. Bloomington: Indiana University Press.

Young, Michael W.

1971 Fighting with food: leadership, values and social control in a Massim society. Cambridge: Cambridge University Press.

\section{Notes}

1 This paper is based on fifteen months fieldwork among the Lelet people in 1990-91. I have benefited greatly from the constructive comments of Aletta Biersack, Margaret Burns, Jim Fox, Margaret Jolly, Andrew Lattas, Ingrid Slotte, Roe Sybylla and Aileen Toohey.

2 All vernacular terms of the Mandak language are in Palatino italics, while all Neo-Melanesian or Tok Pisin terms are in Helvetica italics.

3 This is not to posit a master trope and I accept the cautionary words of Fernandez (1991:5), Ohnuki-Tierney (1991) and Turner (1991:123). The body and its comportments, I argue, are a significant source of what Ohnuki-Tierney refers to as polytropes (1991:160, 185). She describes polytropes as "polysemic symbols whose multiple meanings in various contexts function as different types of trope" (p. 160). Seating is a very good example of a polytrope being used in a wide variety of domains and contexts, referring to both individual bodily states and collective social states.

4 However, Basso does not take from Heidegger what is equally crucial - the concept of Dasein, or Being as unheimlich (see also Dreyfus 1991:45; Heidegger 1962), the notion that people are never truly at home in the world. The process by which people give meaning and develop attachments to a place is not a process free of tensions, ambiguities and contradictions. This process is not devoid of contestation, either of a symbolic or political nature.

5 The movement of larada (masalai) is not unique to the Lelet. One widely known myth from New Ireland is that of Luanga or Loborada, a giant cannibalistic pig masalai, who in the past terrorized the population, forcing them to flee to nearby islands (see also Powdermaker 1933:34-35 and Wagner 1986:25). A woman was left behind by the fleeing people because she had elephantiasis. The woman slept on a beach and was impregnated by a bird, finally giving birth to twin boys who hunted down the pig and killed it. The death of the pig allowed the people to return to their place. People find the 
authenticity of this tale in various things left behind, such as the stones used to cook the pig at Lesu, or hair which fell from the pig in the Dalom River, forming grass. The mountains of the Lelet Plateau are said to be a result of the giant pig digging the earth. A remarkably similar myth is reported by Battaglia (1991:93-94) for Sabarl Island in the Massim area of Papua New Guinea. In the Sabarl version, the deserted woman steps into a giant clam shell and afterwards gives birth to a daughter. The girl then dresses as a boy and kills the pig. Another version of a cannibal monster forcing the population from their place is to be found on Tanna in Vanuatu (Bonnemaison 1985:36).

6 The realm of the non-human world of the people of the Lelet Plateau contains not only larada or masalai but also various other anthropomorphic and monstrous beings which in Neo-Melanesian are called tambaran and which, locally, are called lagas (singular) or lubungas (plural). As with larada, space and place are also delineated by the paths of movement and the homes of these beings. These bush spirits largely inhabit the forest area, which is called the "big bush" (lavatbuan), although the occasional lagas might live in close proximity to a hamlet, generally in a cave, in a large tree or in a clump of bamboo. Unlike the larada, the relationship between humans and lagas is not one of kinship.

7 This is not the case among another New Ireland people, the Barok speakers studied by Roy Wagner, where the masalai can be wrathful toward, and even harm, the members of its own clan (Wagner 1986:101). A similar situation is reported by Brenda Clay who states that, among the Mandak-speaking people of Pinikindu on the east coast of New Ireland, masalai are feared by clan members and non-members alike for causing illness and even death (Clay 1986:54).

8 The Lelet do not recognize these times as natural disasters but as the wilful action of sorcerers.

9 In the past when people reached old age and became infirm, euthanasia was sometimes carried out.

10 A myth recorded by Panoff from the Maenge of East New Britain (Papua New Guinea) is worth recalling. She mentions a people called the Vagaskusime who remain in the condition of a primeval people lacking a digestive system. In order to eat, these beings throw entire taro or coconuts into holes located on the tops of their heads. Significantly, these people "live seated and cannot move so that they are surrounded by their own excrement" (Panoff 1970:244). This is significant for my interpretation because social interaction, and thus society, is predicated on people being able to move.

11 Literally, people translate this as meaning "man bilong bus", evocative of the tambaran who exists in another realm outside of the web of social relationship founded on acts of giving and receiving food. It also describes the "greedy" person who, in the ultimate act of selfishness, incorporates food that could have been used to initiate and sustain social relationships (Munn 1986).

12 The importance of the path or road has been noted by authors writing on cargo cults - for example Peter Lawrence's book (1964) is entitled Road belong cargo and see Jackson (1989:148) for a different context.

13 Again, paradoxically, one younger informant explained to me that he thought the "laziness" of the younger generation was caused by the increased mobility possible through access to cars.

14 Literally it means to sit down in the middle. Other examples are: Kisalawa, which means to live only a short amount of time; Kisgomat, to live in the place, Lavatgomat; Kismiding, to sit on shell money; Kisbin, to sit down in a place without people; Kisnai, to remain seated; Kisauat, to sit down steadfastly like a stone; Kisina, to sit down on a debt; Kismarua, to sit down in the light; Kiskarun, to sit down without parents. Some examples of men's names are; Marasungaon, a large pig worth ten pieces of shell money; Lumamau, something that has "fight" like chilli; Lavatboorong, good pig; Septupe, to kill something and take it to the forest with you; Bungunen, a school of fish; Ligok, a type of fish; Lavasibo, a bone of a pig; Sorong, to try and spear something; Lentos, to blow on a fire to light it; Lorong, a big or good man. 


\section{Contributors}

\section{Nils Bubandt}

(PhD, ANU, 1996) Assistant Professor, Department of Anthropology, University of Aarhus, Hojberg 8270, Denmark.

\section{Richard Eves}

(PhD, ANU, 1995) Australian Research Council Postdoctoral Fellow, Archaeology and Anthropology, The Faculties, The Australian National University, Canberra, ACT 0200, Australia.

\section{James J. Fox}

(D.Phil, Oxford, 1969) Professor and Head, Department of Anthropology, Research School of Pacific and Asian Studies, The Australian National University, Canberra, ACT 0200, Australia. (Convenor of the Comparative Austronesian Project.)

\section{Barbara Dix Grimes}

(PhD, ANU, 1995) Visiting Lecturer, Centre for Regional Studies, Universitas Kristen Artha Wacana, P.O. Box 147, Jl Adisucipto, Oesapa, Kupang, NTT, Indonesia.

\section{Andrew McWilliam}

(PhD, ANU, 1990) Honorary Fellow, Northern Territory University, Darwin, NT 0909, Australia and Anthropologist, Aboriginal Areas Protection Authority, GPO Box 1890, Darwin, NT 0801, Australia.

\section{Sandra Pannell}

(PhD, Adelaide, 1991) Independent researcher and consultant anthropologist, Nguwarriz Anthropological Services, 49 Nelson Street, South Townsville, Queensland 4810, Australia.

\section{Minako Sakai}

Research Scholar, Department of Anthropology, Research School of Pacific and Asian Studies, The Australian National University, Canberra, ACT 0200, Australia.

\section{Philip Thomas}

(PhD, LSE, 1996) Postdoctoral Fellow, Department of Anthropology, University College London, Gower Street, London WCIE 6BT, UK. 
The Poetic Power of Place

\section{Roxana Waterson}

(PhD, Cambridge, 1981) Senior Lecturer, Department of Sociology, National University of Singapore, Singapore. 